
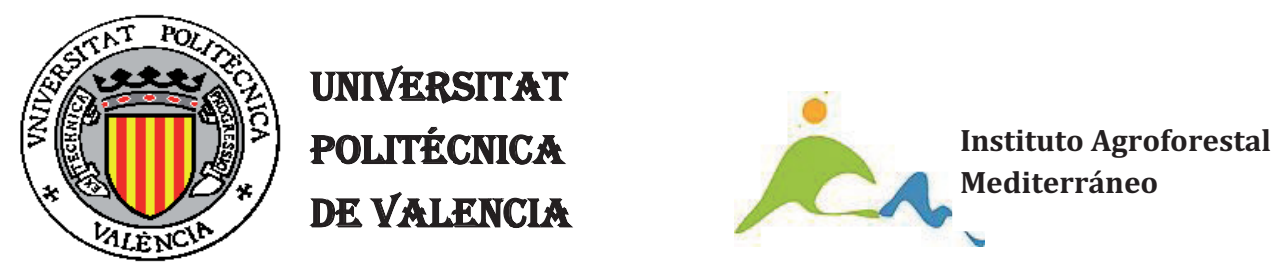

ESCUELA TÉCNICA SUPERIOR DE INGENIEROS AGRÓNOMOS DEPARTAMENTO DE ECOSISTEMAS AGROFORESTALES

\title{
Biological control of California red scale, Aonidiella aurantii (Hemiptera: Diaspididae): spatial and temporal distribution of natural enemies, parasitism levels and climate effects
}



A mi padre,

fuente constante de inspiración, apoyo y admiración 

There is a pleasure in a forest without path; there is an ecstasy in a solitary beach. The bridges of Madison County Hay un placer en un bosque sin sendero, hay un éxtasis en una playa solitaria.

Los puentes de Madison Robert JamesWaller 



\section{Acknowledgements}

Throughout the five years this thesis have been performing I have received a great help by many people in any of the aspects this work involves, field surveys, insect identification and counting, laboratory experiments and articles preparation. Since it would be almost impossible to cite all of them I would like to express my deepest and sincere grateful to all persons that made this doctoral thesis possible.

I would like to express my deepest gratitude to Dr. Ferran Garcia-Marí, my thesis advisor, for accept me in his research team to perform this fascinating work under his guidance, for transmitting to me his passion for the entomology scientific research and the accuracy in the articles performing, for his always measured and good advices and for being always available for the dialogue and discussion about the work.

My deep appreciation to Dr. Joan van Baaren for receiving me at the ECOBIO Institute, her support and guidance with the laboratory experiments, her help with the articles writing and for showing me so many beautiful things from Bretagne.

A very special thankful to Raquel Rodríguez, for sharing the effort of the parasitoids counting during so many hours, for her essential contribution in the identification of the species, her friendship and her help.

I would like to acknowledge Dr. Jacques van Alphen his advices and correction of the first article and his help with the laboratory trials design and preparation and to Dr. Jean-Sébastien Pierre for admitting me in Ecobio Institute and for his help with the statistical analysis included in the third article.

It would be not possible to perform the laboratory experiments and the introductory releases without the supply of parasitoids from the Almassora and Silla Insectariums to which staff I owe special gratitude, mainly to Alberto García, Maribel Deval, Mamen Laurin and Juan Felipe Rodríguez. I would like also to thank Esteban Soler for the climatic data of Callosa and the information related with releases of A. lingnanensis and all Tragsatec-Citrus Phytosanitary Survey staff for the field trap samples

My sincerest gratitude to Dr. Eugenia Rodrigo for her invaluable help with the identification of Aphytis, to Dr. Rosa Vercher for her comments and advice with the first article, mainly with the aspects related with parasitoids ecology, for her help and support in Catania Congress and many other things, to Dr. Francisco Ferragut for his help with the identification of mite predators and his huge kindness, to Dr. María Jesús Verdú for the information related with parasitoid releases, her comments as supervisor of the thesis and the help with the identification of A. lingnanensis, to Dr. Alejandro Tena for addressing me 
in the preparation of the first paper, his advices and his friendship during all these years, to Dr. María Teresa Martínez for the information related with red scale and parasitoid status in the northest areas and to Dr. Lucia Zappala for her deep review on the early version of the thesis and her English corrections.

Special thanks to Dr. Sandra Gandolfo and Dr. Mercedes Verdeguer for their help and advices during the writting period of this thesis and their sincere friendship and to Dr. William Murdoch, Dr. Robert Luck and Dr. Jerome Casas for their comments, observations and recommendations related with the articles.

It was a pleasure for me to share all this time with my doctoral colleagues at IAM, David, Cristina, Tolis, Juan Antonio, Alex, Amparo, Carmina and Carlos, thanks for the good moments, for your friendship, your advices and your help.

I would like to acknowlege Mohannad, Joffrey, Cecile, Damien and all our collegues and technicien of Ecobio Institute (UMR- CNRS 6553) and University of Rennes for their help and for sharing a very beautiful research period in France.

Thanks Rosa, for the many days you helped me with the field surveys, for being always next to me and supporting me, for been wonderful and for your love without limits.

Finally, I would like to thank Ministerio de Ciencia y Tecnología for the economic support to the proyect "Control biológico y umbrales de tratamiento del piojo rojo de California Aonidiella aurantii (Homoptera: Diaspididae) en cítricos" (Ref:: AGL200507155-C03-03/AGR) in which this thesis is included. 


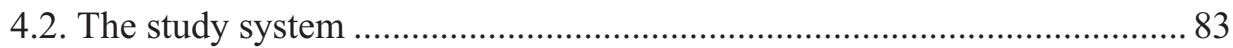

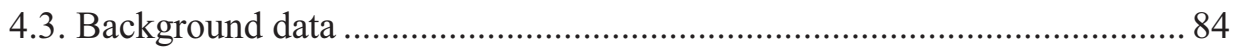

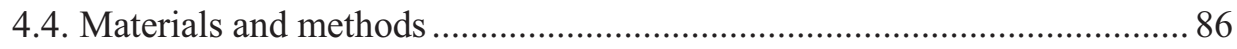

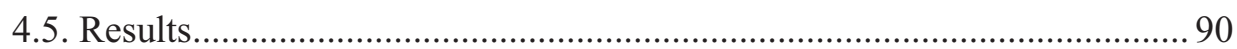

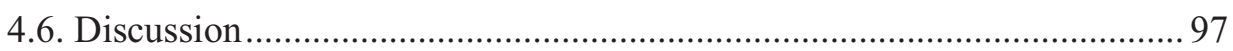

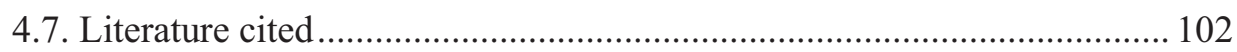

Chapter 5. Article: Comparative efficacy of different combinations of natural enemies for the biological control of California red scale in citrus groves 109

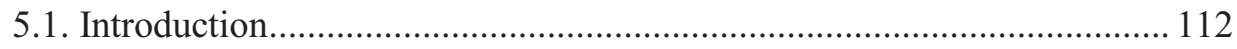

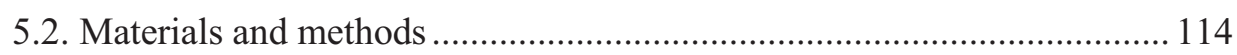

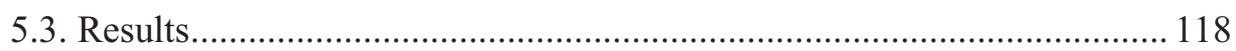

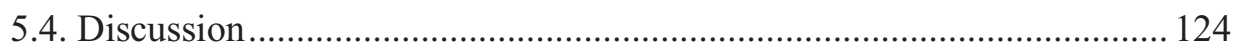

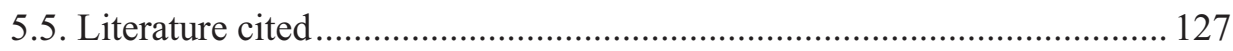

Chapter 6. Article: Effects of climate on the introduction, distribution and biotic potential of parasitoids: Applications to biological control of

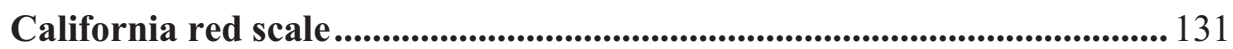

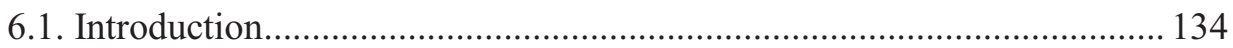

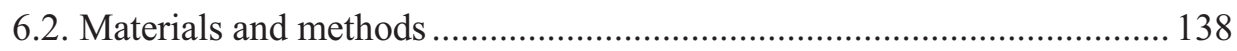

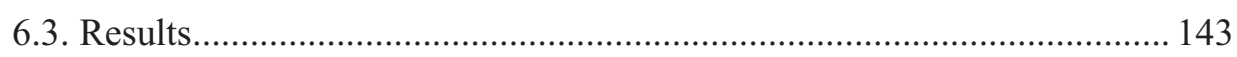

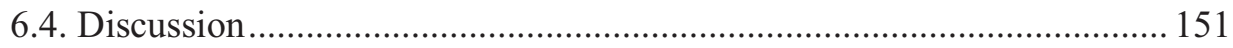

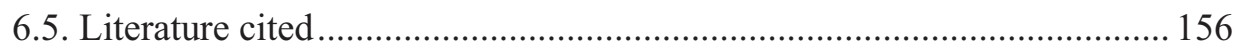

Chapter 7. General discussion ........................................................................................ 163

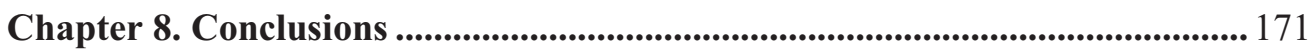

Note: Present book has been organized so that the main results have been written in the form of scientific articles published in international Journals, or in process of being published. The chapters containing these articles are 4, 5 and 6.

All figures, photos and charts were made by the author unless other is indicated in the footnotes. 


\section{Summary}

In many citrus areas around the world the California red scale (CRS) Aonidiella aurantii (Hemiptera: Diaspididae) is considered a key pest. In eastern Spain it has spread during the last decades up to cover a vast extension of citrus landscapes. The chemical control of CRS is difficult, and is frequently followed by recurrent infestations in a short period, the appearance of resistance to different products used for its control and the elimination of natural enemies present in the field. The improvement of integrated pest management and biological control techniques for CRS requires the knowledge of the natural enemy species composition in each climatic zone, their seasonal fluctuation in abundance, parasitism and predatory levels, how they distribute in the plant, and how they are affected by the climate.

Although much has been studied in laboratory about the Aphytis (Hymenoptera: Aphelinidae) parasitoids, the main control agents of CRS, it is still not well-known which combination of natural enemies achieves better host control in the field, how parasitism rate varies along the year or how parasitoids distribute and compete in the field in relation to climate. The action of Aphytis, ectoparasitoids, is complemented in many citrus areas by the endoparasitoids Comperiella bifasciata (Hymenoptera: Encyrtidae) and Encarsia perniciosi (Hymenoptera: Aphelinidae) which can parasitize different scale instars than Aphytis species. Very little is known about the fitness and the biological responses under different climate conditions of these endoparasitoids. Similarly, the impact of predators on the scale population has been rarely studied.

Currently, in Eastern Spain, A. melinus, an introduced species and the superior competitor, has displaced the native parasitoid Aphytis chrysomphali from hot and dry areas (inland and southern areas) as it can better tolerate summer hot temperatures. However, in contrast to what it happens in most citrus areas around the world, both A. melinus and A. chrysomphali coexist along the coast. The relative abundance of $A$. chrysomphali increases from south to north, being in higher percentage in the northern areas where summer is milder. Declining temperatures during autumn and winter have a greater negative effect on $A$. melinus than $A$. chrysomphali, since the indigenous $A$. chrysomphali is more cold-tolerant and better adapted to these 
weather conditions. The negative effect of winter temperatures on A. melinus allows the earlier use of the available host resource in late winter and spring by $A$. chrysomphali and the coexistence of both parasitoids in the same orchard via temporal niche partitioning, being A. melinus more abundant during the summer. In addition, as both parasitoids prefer different red scale instars for parasitism (smaller for A. chrysomphali) its combination in the field could result in a better CRS control. We demonstrate the role of spatiotemporal weather conditions and seasonal changes in host stages on the variation of parasitoids relative abundance and coexistence.

The parasitoids E. perniciosi and Aphytis lingnanensis were found only in a coastal semitropical area (La Marina) being the former the most abundant (13\% of the total parasitoids found). The parasitoids of A. aurantii show different scale instars and different periods of the year as preferred for parasitism. Aphytis melinus parasitized more young females whereas $A$. chrysomphali preferred second instar stages and E. perniciosi highly parasitized scale molts and gravid females that are not parasitizable by Aphytis. In the orchards where A. melinus was present in high numbers, either alone or coexisting with $A$. chrysomphali, parasitism rates were higher (average 22.4\%) than in the orchards where A. chrysomphali was the dominant parasitoid (average 11.5\%). The levels of parasitism by Aphytis spp. were highest between August and November and lowest in February and March. The annual average parasitism rate by E. perniciosi was $12.3 \%$, reaching the highest levels during the spring. Scales on fruits were more preferred for parasitism by Aphytis than those on twigs whereas E. perniciosi parasitized more scales on twigs. The best parasitism level was achieved when the ectoparasitoids A. melinus and A. chrysomphali occurred together with the endoparasitoid E. perniciosi. The reason was that they complement each other on controlling the different parts of the tree, the different CRS stages and the different seasons of the year. The average annual mortality rate of $A$. aurantii was $73.6 \%$. The analysis of dead scales killed by Aphytis confirmed the results obtained in parasitism of live scales. The most abundant predators were Lestodiplosis aonidiellae (Diptera: Cecidomyiidae) and Rhyzobius lophantae (Coleoptera: Coccinellidae). Predators had much lower incidence on CRS populations than parasitoids but high effect on controlling mobile crawlers and mature female scales, showing the importance of keeping a high natural enemy complex in the field for a good control of the pest. 
Slight differences in winter and summer temperatures or humidity conditions between contiguous Mediterranean ecosystems are responsible of large variations in parasitoid species composition emphasizing the importance of considering temperature and humidity at different levels besides the optimal. Introductory releases of $C$. bifasciata achieved the establishment in groves placed in the inland citrus area whereas E. perniciosi and $A$. lingnanensis established only in the semitropical area. Experiments in laboratory, to complement field results, determined the decisive influence on the introduced parasitoids C. bifasciata and E. perniciosi of the extreme climatic conditions that occur naturally. The highest $r_{m}$ values for $C$. bifasciata and E. perniciosi were reached at temperature-humidity regimes typical from inland and subtropical citrus areas respectively, the same areas in which releases of these parasitoids achieved their establishment. The longevity of both species at different temperature-humidity conditions also reflected their adaptability to dry or humid areas. These results, together with the $r_{m}$ values obtained by other authors on Aphytis species and their field distribution, demonstrate that the study of life-history traits and the $r_{m}$ of parasitoids under different temperature-humidity conditions constitute a valid method to predict the potential areas of establishment and distribution of newly introduced insects. Previous unsuccessful releases and the distribution of CRS parasitoids in different citrus areas around the world can be explained through the $r_{m}$ of these insects at different temperature-humidity regimes. 


\section{Resumen}

En muchas áreas citrícolas del mundo el piojo rojo de California (PRC), Aonidiella aurantii (Hemiptera: Diaspididae), está considerado una plaga clave. En el Este de España se ha extendido durante las últimas décadas hasta cubrir una amplia extensión de cítricos. El control químico es difícil y frecuentemente es seguido de infestaciones recurrentes en poco tiempo, de la aparición de resistencias a diferentes productos usados para su control y de la eliminación de enemigos naturales en el campo. La mejora del manejo integrado y las técnicas de control biológico del PRC requieren conocer la composición de los enemigos naturales en cada zona climática, la fluctuación en su abundancia estacional, los niveles de parasitismo y depredación, como se distribuyen en la planta y como son afectados por el clima y el cambio climático.

Aunque mucho se ha estudiado en laboratorio sobre los parasitoides Aphytis (Hymenoptera: Aphelinidae), los principales agentes de control del $\mathrm{PRC}$, todavía no se conoce qué combinación de enemigos naturales consigue el mejor nivel de control en el campo, cómo varían los niveles de parasitismo a lo largo del año o cómo los parasitoides se distribuyen y compiten en el campo en relación con el clima. La acción de los Aphytis, ectoparasitoides, es complementada en muchas zonas citrícolas por los endoparasitoides Comperiella bifasciata y Encarsia perniciosi (Hymenoptera: Aphelinidae), los cuales pueden parasitar estadíos diferentes a Aphytis. Muy poco se sabe sobre el comportamiento y las respuestas biológicas bajo diferentes condiciones climáticas de estos endoparasitoides. Del mismo modo, el efecto de los depredadores sobre la población del piojo ha sido raramente estudiado.

Actualmente, A. melinus, una especie introducida en el Este de España y el competidor superior, ha desplazado al parasitoide nativo $A$. chrysomphali de las zonas cálidas y secas ya que puede tolerar mejor las temperaturas cálidas del verano. Sin embargo, en contraste con lo que sucede en la mayoría de las zonas citrícolas del mundo, ambos $A$. melinus y $A$. chrysomphali coexisten a lo largo de la costa. La abundancia relativa de $A$. chrysomphali aumenta de sur a norte, siendo su porcentaje mayor en las zonas más septentrionales donde los veranos son más suaves. El descenso de las temperaturas durante el otoño y el invierno tiene un efecto más negativo sobre $A$. melinus que $A$. chrysomphali, ya que el nativo $A$. chrysomphali es 
más resistente al frío y está mejor adaptado a estas condiciones climáticas. El efecto negativo de las temperaturas invernales sobre $A$. melinus permite al $A$. chrysomphali anticiparse en su acción sobre el huésped durante el final del invierno y primavera y la coexistencia de ambos vía partición temporal del nicho, siendo A. melinus más abundante durante el verano. Además, dado que ambos parasitoides prefieren diferentes estadios del piojo rojo para parasitar (de menor tamaño $A$. chrysomphali) su combinación en el campo puede permitir un mejor control del PRC. Demostramos el efecto de las condiciones climáticas espacio-temporales y los cambios estacionales en los estadios del huésped, en la variación de la abundancia relativa de Aphytis y la coexistencia de los parasitoides.

Los parasitoides E. perniciosi y Aphytis lingnanensis se encontraron exclusivamente en una zona costera semitropical (La Marina) siendo el primero el más abundante (13\% del total de parasitoides encontrados). Los parasitoides de $A$. aurantii mostraron diferentes preferencias en cuanto a los estadios y periodos del año para el parasitismo. Aphytis melinus parasitó más hembras jóvenes mientras Aphytis chrysomphali prefirió segundo estadio y $E$. perniciosi parasitó en gran medida estadios de muda y hembras grávidas que no son parasitables por Aphytis. En las parcelas donde A. melinus estaba presente en elevada cantidad, sólo o coexistiendo con $A$. chrysomphali, los niveles de parasitismo fueron superiores (media 22.4\%) que en las parcelas donde A. chrysomphali era el parasitoide dominante (media 11.5\%). Los niveles de parasitismo por Aphytis fueron mayores entre Agosto y Noviembre y menores en Febrero y Marzo. El parasitismo anual medio de E. perniciosi fue del $12.3 \%$, alcanzando los niveles más altos durante la primavera. Los mejores niveles de parasitismo se alcanzaron cuando los ectoparasitoides Aphytis se encontraban junto con el endoparasitoide E. perniciosi ya que todos ellos se complementan en el control de las distintas zonas del árbol, los estadios del PRC y los diferentes estaciones del año. El porcentaje de mortalidad anual de A. aurantii fue del $73.6 \%$. El análisis del los escudos muertos por Aphytis confirma los resultados que se obtuvieron en parasitismo sobre los vivos. Los depredadores más abundantes fueron Lestodiplosis aonidiellae (Diptera: Cecidomyiidae) y Rhyzobius lophantae (Coleoptera: Coccinellidae). Los depredadores tuvieron mucha menor incidencia sobre las poblaciones de PRC que los parasitoides pero alto efecto en el control de larvas móviles y hembras maduras, mostrando la importancia de mantener un alto nivel de enemigos naturales en el campo para un buen control de la plaga. 
Pequeñas variaciones en las temperaturas de invierno y verano o en las condiciones de humedad entre ecosistemas Mediterráneos contiguos son responsables de grandes variaciones en la composición de las especies de parasitoides. Las sueltas introductorias de $C$. bifasciata lograron el establecimiento en zonas citrícolas de interior mientras que $E$. perniciosi y $A$. lingnanensis se establecieron sólo en la zona semitropical. Los experimentos en laboratorio, para complementar los resultados de campo, determinaron la decisiva influencia de las condiciones climáticas extremas que se dan de forma natural sobre los parasitoides introducidos $C$. bifasciata y $E$. perniciosi. Los mayores valores de $r_{m}$ para C. bifasciata y E. perniciosi se alcanzaron para regímenes de temperatura-humedad típicos de zonas citrícolas interiores y semitropicales respectivamente, las mismas zonas en las cuales las sueltas de estos parasitoides lograron su establecimiento. La longevidad de ambas especies a diferentes condiciones de temperatura y humedad también reflejó su adaptabilidad a zonas secas o húmedas. Estos resultados, unidos a los valores de $r_{m}$ obtenidos por otros autores con los Aphytis y su distribución en campo, demuestran que el estudio de la historia de vida y el $r_{m}$ de los parasitoides bajo diferentes condiciones de temperatura y humedad constituye un método válido para predecir las áreas potenciales de establecimiento y distribución de insectos de nueva introducción. Los fracasos en las sueltas anteriores y la distribución de los parasitoides del PRC en diferentes zonas citrícolas del mundo pueden ser explicados mediante el $r_{m}$ de estos parasitoides a diferentes regímenes de temperatura y humedad. 
En moltes àrees citrícoles del món el poll roig de Califòrnia (PRC), Aonidiella aurantii (Hemiptera: Diaspididae), està considerat una plaga clau. En l'Est d'Espanya s'ha estés durant les últimes dècades fins a cobrir una àmplia extensió de cítrics. El control químic és difícil i freqüentment és seguit d'infestacions recurrents en poc de temps, de l'aparició de resistències a diferents productes usats per al seu control i de l'eliminació d'enemics naturals en el camp. La millora del maneig integrat i les tècniques de control biològic del PRC requereixen conéixer la composició dels enemics naturals en cada zona climàtica, la fluctuació en la seua abundància estacional, els nivells de parasitisme i depredació, com es distribuïxen en la planta, i com són afectats pel clima i el canvi climàtic.

Encara que molt s'ha estudiat en laboratori sobre els parasitoids Aphytis (Hymenoptera: Aphelinidae), els principals agents de control del PRC, encara no es coneix quina combinació d'enemics naturals aconseguix el millor nivell de control en el camp, com varien els nivells de parasitisme al llarg de l'any o com els parasitoids es distribuïxen i competixen en el camp en relació amb el clima. L'acció dels Aphytis, ectoparasitoids, és complementada en moltes zones citrícoles pels endoparasitoids Comperiella bifasciata i Encarsia perniciosi (Hymenoptera: Aphelinidae), els quals poden parasitar estadis diferents a Aphytis. Molt poc se sap sobre el comportament i les respostes biològiques baix diferents condicions climàtiques d'estos endoparasitoids. De la mateixa manera, l'efecte dels depredadors sobre la població del poll ha sigut rarament estudiat.

Actualment, A. melinus, una espècie introduïda en l'Est d'Espanya i el competidor superior, ha desplaçat al parasitoid natiu $A$. chrysomphali de les zones càlides $\mathrm{i}$ seques ja que pot tolerar millor les temperatures càlides de l'estiu. No obstant, en contrast amb el que succeïx en la majoria de les zones citrícoles del món, estos dos parasitoids, A. melinus i A. Chrysomphali, coexistixen al llarg de la costa. L'abundància relativa de A. chrysomphali augmenta de sud a nord, sent el seu percentatge major en les zones més septentrionals on els estius són més suaus. El descens de les temperatures durant la tardor i l'hivern té un efecte més negatiu sobre $A$. melinus que $A$. chrysomphali, ja que el natiu $A$. chrysomphali és més resistent al fred i està millor adaptat a estes condicions climàtiques. L'efecte negatiu de les 
temperatures hivernals sobre $A$. melinus permet al A. chrysomphali anticiparse en la seua acció sobre l'hoste durant el final de l'hivern i primavera i la coexistència d'estos dos via partició temporal del nínxol, sent $A$. melinus més abundant durant l'estiu. A més, atés que estos dos parasitoids preferixen diferents estadis del poll roig per a parasitar (de menor tamany para $A$. chrysomphali) la seua combinació en el camp pot permetre un millor control del PRC. Demostrem l'efecte de les condicions climàtiques espai-temporals i els canvis estacionals en els estadis de l'hoste, en la variació de l'abundància relativa d'Aphytis i la coexistència dels parasitoids.

Els parasitoids E. perniciosi i Aphytis lingnanensis es van trobar exclusivament en una zona costera semitropical (La Marina) sent el primer el més abundant (13\% del total de parasitoids trobats). Els parasitoids de $A$. aurantii van mostrar diferents preferències quant als estadis i períodes de l'any per al parasitisme. Aphytis melinus va parasitar més femelles jóvens mentre Aphytis chrysomphali va preferir segon estadi i E. perniciosi va parasitar en gran manera estadis de muda $\mathrm{i}$ femelles gràvides que no són parasitables per Aphytis. En les parcel·les on A. melinus estava present en elevada quantitat, només o coexistint amb $A$. chrysomphali, els nivells de parasitisme foren superiors (mitjana 22.4\%) que en les parcel·les on $A$. chrysomphali era el parasitoid dominant (mitjana 11.5\%). Els nivells de parasitisme per Aphytis van ser majors entre Agost i Novembre i menors al Febrer i Març. El parasitisme anual mitjà d'E. perniciosi va ser del 12.3\%, arribant als nivells més alts durant la primavera. Els polls sobre fruits foren preferits per a parasitar per Aphytis comparats amb els polls sobre branques, mentre que E. perniciosi parasita més polls sobre branques. Els millors nivells de parasitisme s'observaren quan els ectoparasitoids Aphytis es trobaven junt amb els endoparasitoids E. perniciosi ja que tots ells es complementen en el control de les distintes zones de l'arbre, els estadis del PRC i els diferents estacions de l'any. El percentatge de mortalitat anual de $A$. aurantii va ser del $73.6 \%$. L'anàlisi dels escuts morts per Aphytis confirma els resultats que es van obtindre en parasitisme sobre els vius. Els depredadors més abundants van ser Lestodiplosis aonidiellae (Díptera: Cecidomyiidae) i Rhyzobius lophantae (Coleoptera: Coccinellidae). Els depredadors van tindre molta menor incidència sobre les poblacions de PRC que els parasitoids però alt efecte en el control de larves mòbils i femelles madures, mostrant la importància de mantindre un alt nivell d'enemics naturals en el camp per a un bon control de la plaga. 
Xicotetes variacions en les temperatures d'hivern i estiu o en les condicions d'humitat entre ecosistemes Mediterranis contigus són responsables de grans variacions en la composició de les espècies de parasitoids. Les soltes introductòries de $C$. bifasciata van aconseguir l'establiment en zones citrícoles d'interior mentre que E. perniciosi i $A$. lingnanensis es van establir només en la zona semitropical. Els experiments en laboratori, per a complementar els resultats de camp, van determinar la decisiva influència de les condicions climàtiques extremes que es donen de forma natural sobre els parasitoids introduïts C. bifasciata i E. perniciosi. Els majors valors de rm per a C. bifasciata i E. perniciosi es van aconseguir per a règims de temperatura-humitat típics de zones citrícoles interiors $\mathrm{i}$ semitropicals respectivament, les mateixes zones en les quals les soltes d'estos parasitoids van aconseguir el seu establiment. La longevitat d'ambdós espècies a diferents condicions de temperatura i humitat també va reflectir la seua adaptabilitat a zones seques o humides. Estos resultats, units als valors de $\mathrm{r}_{\mathrm{m}}$ obtinguts per altres autors amb els Aphytis i la seua distribució en camp, demostren que l'estudi de la història de vida $\mathrm{i}$ el $\mathrm{r}_{\mathrm{m}}$ dels parasitoids baix diferents condicions de temperatura $i$ humitat constituïx un mètode vàlid per a predir les àrees potencials d'establiment i distribució d'insectes de nova introducció. Els fracassos en les soltes anteriors i la distribució dels parasitoids del PRC en diferents zones citrícoles del món poden ser explicats per mitjà del $r_{m}$ d'estos parasitoids a diferents règims de temperatura $i$ humitat. 



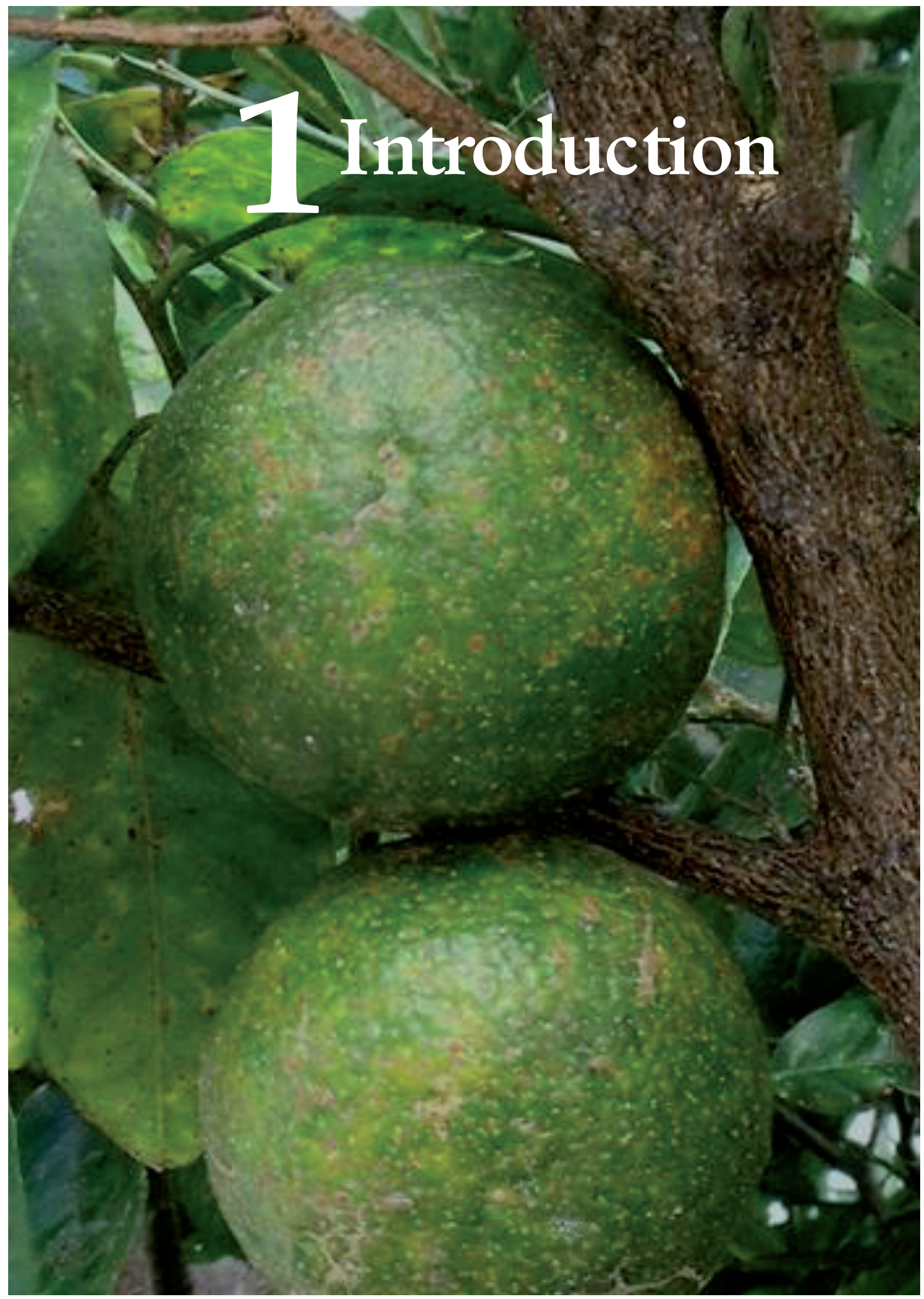





\subsection{The California red scale, Aonidiella aurantii (Maskell)}

The California red scale, Aonidiella aurantii (Maskell), belongs to the Diaspididae (Hemiptera: Coccoidea) family also called armored scale insects. This is a large family of highly evolved specialized plant parasites. The armored scales constitute the predominant citrus-infesting insect fauna in the majority of the citrusgrowing regions of the world (Ebeling, 1959). Not only are they widely distributed, but it is difficult to control them. They are insects provided with piercing mouth parts with which they suck sap from parenchyma cells of the plant tissue (Bedford, 1998). The head and the thorax are fused, and segments of the abdomen are also fused into a much-constricted area called the pygidium.

The armored scales are hidden under an "armor" or "scale" covering. This covering consists of wax secreted by the insect, plus the exuviae or cast skins. The exuviae are added to the armor during the molt. The scales then add threads wax secreted from the pygidium to the outer edge of the armor. An outer fringe of wax is thus added to the armor and this offers protection to the growing insect, which eventually fills its new covering and molts, thus adding another cast skin to its armor (Rosen, 1990).

Aonidiella aurantii was initially described in New Zealand in 1878 by W. M. Maskell as Aspidiotus aurantii. The California red scale (CRS) is probably the most extended citrus pest in the world (Quayle, 1941; Ebeling, 1959). Its presence has been described in most citrus areas, mainly tropical and subtropical, included Australia, all Mediterranean citrus regions, south and southeast of Africa, Central and South America, the USA citrus areas, Middle East and all citrus areas of the Oriental region (Flanders, 1971; Viggiani, 1988; Claps et al. 2001; Hill, 2008).

The common names used to refer A. aurantii are: "California red scale" in or just "red scale" in English speaking countries, "piojo rojo de California" in Spain, "escama roja" in South America, "cocciniglia rossa forte degli agrumi" in Italy, "cochinille jaune" or "pou de Californie" in French and "Cochonilha vermelha dos citrinos" in portuguese speaking countries. 


\subsubsection{Systematic classification.}

Aonidiella aurantii belongs to the order Hemiptera, superfamily Coccoidea, family Diaspididae. The taxonomy of this family has been based almost exclusively on characteristics of the adult female. The Diaspididae are ranked as the most specialized forms of coccids, located at the extremity of the evolutionary lineage (Ben-Dov, 1990).

Its classification is as follows:

Order Hemiptera

Suborder Homoptera

Series Sternorrhyncha

Superfamily Coccoidea

Family Diaspididae

Tribe Aspidiotini

Genus Aonidiella

Species Aonidiella aurantii (Maskell)

\subsubsection{Injurious effects of Aonidiella aurantii}

Aonidiella aurantii is a cosmopolitan and polyphagous insect which is considered one of the most important pests of citrus. It occurs on host-plants belonging to at least 77 plant families (Borchsenis, 1966). Apart from citrus, serious attacks have occasionally been described in species of the genus: Ceratonia (carob), Eucalyptus (eucalyptus), Hedera (ivy), Juglans (walnut), Laurus (laurel), Mangifera (mango), Morus (mulberry), Olea (olive), Passiflora (passion fruit), Pyrus (pear), Rosa (rose), Zizyphus (jujube), Ficus (fig tree), Ligustrum (privet) and many others (Fig. 1.1). (Quayle, 1941; Deckle, 1976; Murray, 1976; Smith et al., 1997).

California red scale attacks all aerial parts of the citrus tree including twigs, leaves, branches, and fruit by sucking the sap on the plant tissue with their long, filamentous mouthparts. The presence of this insect weakens the infested organ and the plant itself, causing thereafter deformations by the action of toxic saliva (Beardsley and Gonzalez, 1975; Washington and Walker, 1990). Infested fruit may be downgraded in the packinghouse, for instance in South Africa no more than 6 


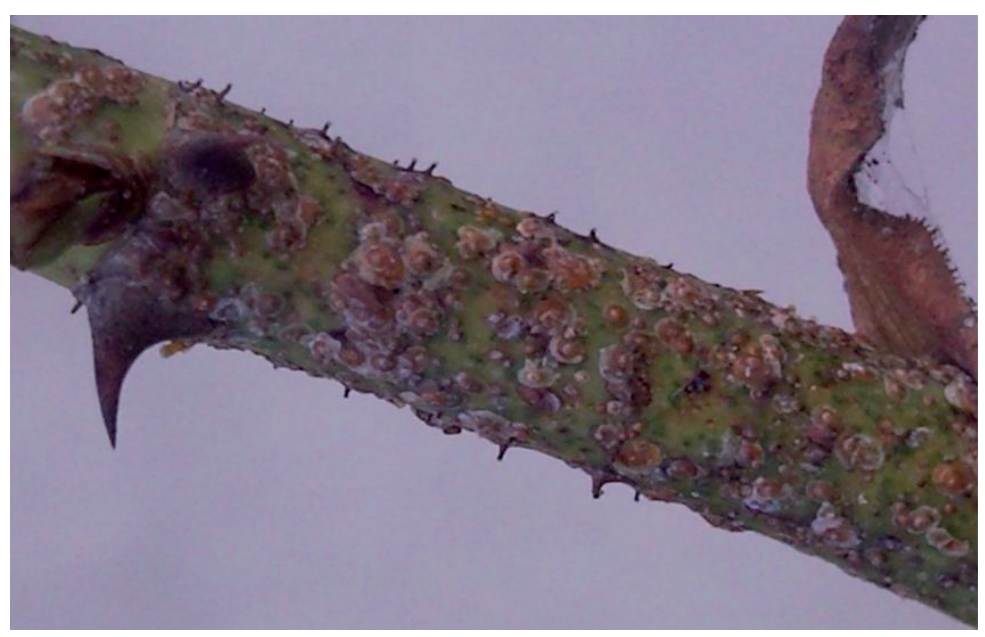

Fig. 1.1. Branch of a rose plant infested with California red scale (Aonidiella aurantii)

scale insects $>1 \mathrm{~mm}$ diameter are allowed per orange for export grade. For lemons and soft citrus, the thresholds are 5 and 4 scale insects respectively (Bedford, 1998).

In the case of severe infestations on young fruit, developing scales form prominent pits which are still evident when the fruit matures. The sucking of the fruit cells by the scale cause chlorosis and yellowing in fruit when still green in colour; extremely intense attacks may encrust the fruit and dry it up to mummification (Fig. 1.2). Injurious effects include the yellowing of foliage (the leaves develop a characteristic yellow spot under and around each female scale) and defoliation; the dying back of small twigs (Fig. 1.3), the large branches, and finally, if the insect remains unchecked, big parts of the tree can be killed (Fig. 1.4). Occasionally severe infestations can cause even the death of the tree. If population levels are high the final crop can also be reduced by defoliation and dieback. Tree damage is most likely to occur in late summer and early fall when scale populations are highest and water stress on the tree is greatest (Ebeling, 1959; Crouzel et al., 1973; Smith et al., 1997). 

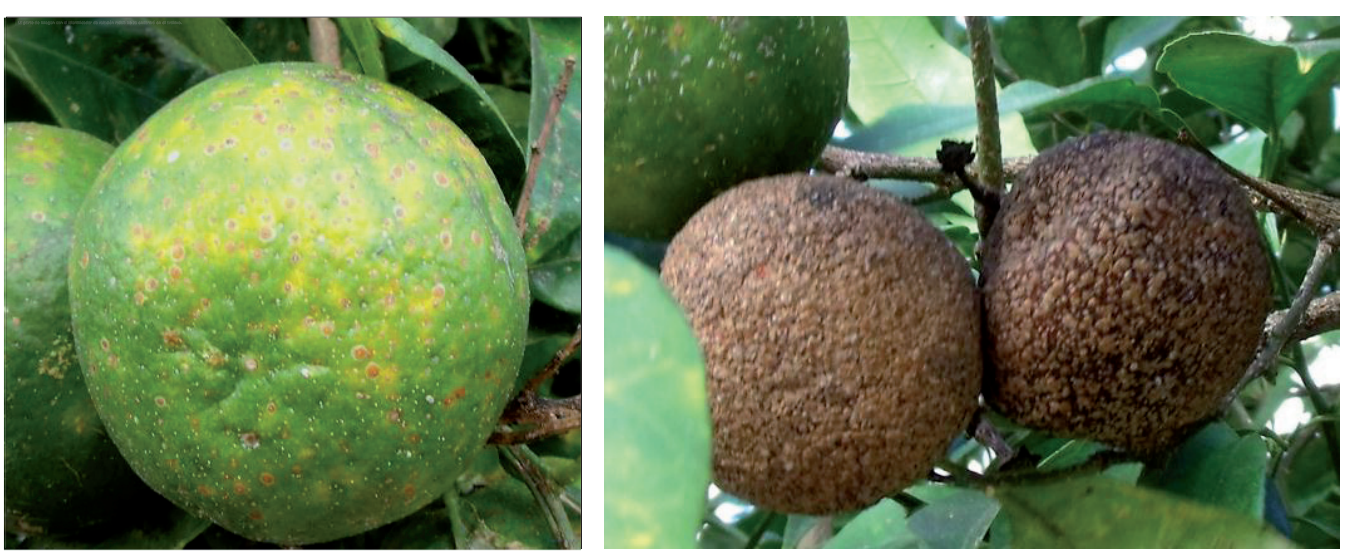

Fig 2. Yellowing in fruit (left) and mummification of fruits (right) caused by serious attacks of California red scale.
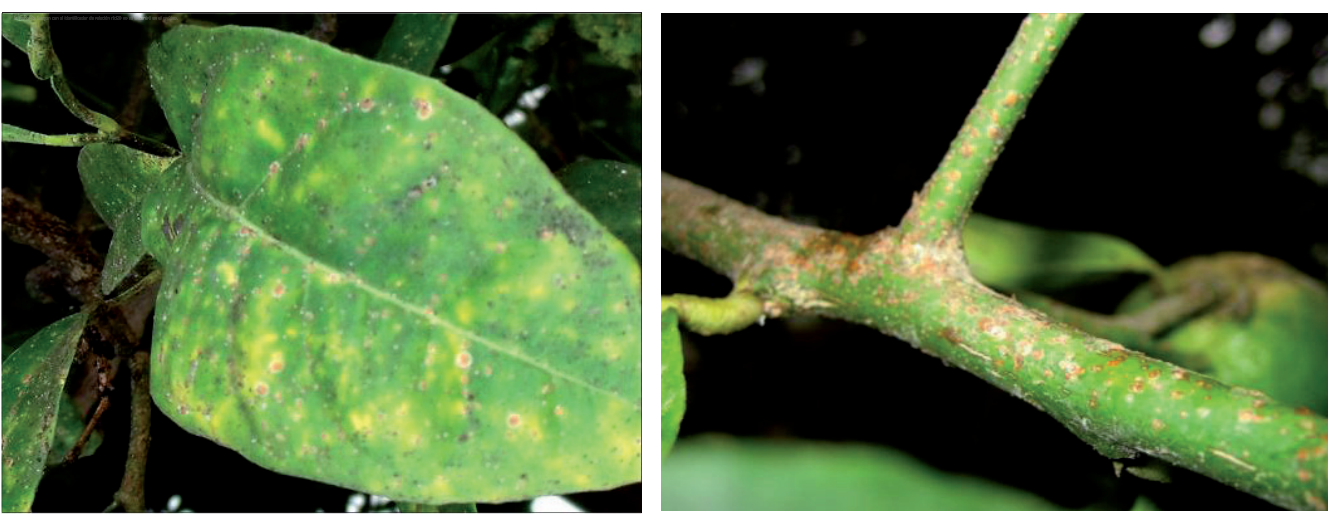

Fig. 1. 3. Yellowing of leaf (left) and twig infestation (right) by California red scale.
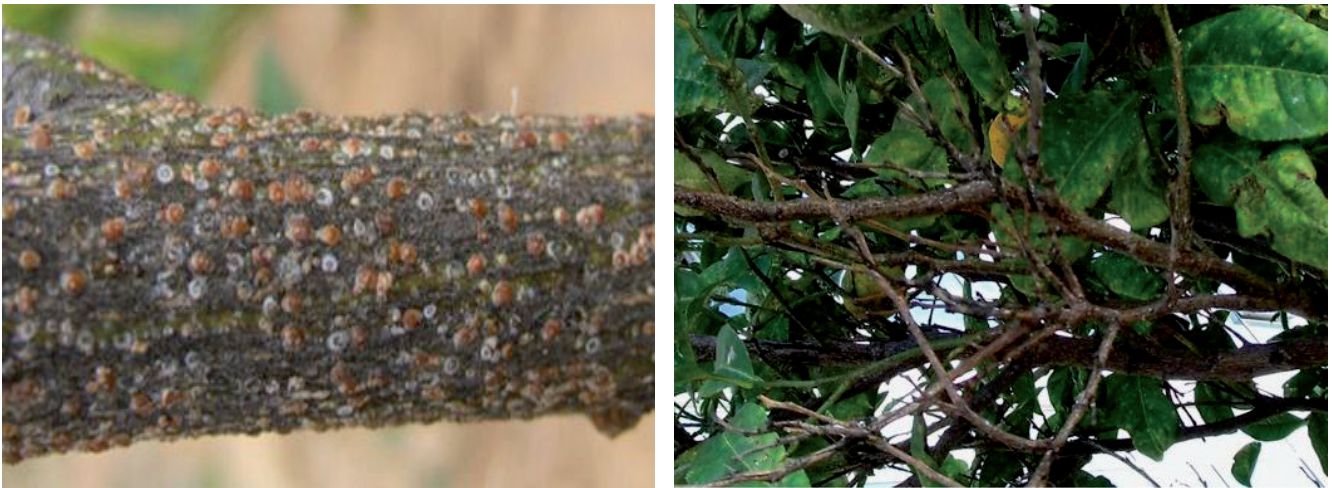

Fig. 1. 4. A large branch (left) and big part of the tree (right) infested by California red scale. 
Some ant species can induce heavy infestations of red scale (Annecke, 1959; Compere, 1961; Bedford, 1998; Pekas et al., 2010). They patrol the branches to obtain honeydew from soft scale insects, mealybugs, and aphids. Their restless activity deters parasitoids and predators. The honeydew-producing insects increase rapidly and provide more food for ants but red scale (which provides nothing for the ants) also increases quite out of proportion to its normal low level in the absence of ants. Ants can thus be responsible for making A. aurantii a major pest (Bedford, 1998).

One of the main economic impact of the CRS is not that it can deform fruit or cause undefined loss in yield, but that the fruit may be rejected, since under existing regulations there is zero tolerance for scale on fruit intended for local or overseas markets (McLaren \& Buchanan, 1973). Else, Aonidiella aurantii is included in the quarantine lists of several countries as it is easily transported on infested fruit and planting material (Burger and Ulenberg, 1990).

\subsubsection{Life history}

Biology of Aonidiella aurantii has been very much studied due to its economic importance. Detailed descriptions of the CRS life history were given during the central part of the past century by Quayle (1941), Bodenheimer (1951) and Ebeling (1959). The apparent reddish colour of the scale covering of the insect, which gives its name, is not the colour of this structure itself, but rather the colour of the body of female as seen through the scale covering. The CRS is ovoviviparous, that is, the egg hatches within the body and young are born. The larva may remain beneath the scale covering for a day or two. This brief period is the only time in the life of the insect when it is capable of moving about, and is commonly referred to as "crawler" stage.

The adult female gives birth to 50-450 mobile young crawlers, at the rate of two to three per day over a six to eight week period. Females on citrus fruit in Zimbabwe (Parry-Jones, 1936) produce 66 - 143 crawlers in 33 - 48 days each, depending on environmental conditions, whereas in laboratory conditions of $25^{\circ} \mathrm{C}$ and $70 \% \mathrm{RH}$ each female produce 352 crawlers on average (Tashiro and Beavers, 1968). The highest rate of production is almost 7 crawlers per day per female in

$$
-7-
$$


summer, but only one crawler per day in winter (Parry-Jones, 1936). The crawlers emerge from under their mothers scale cover, and search for a suitable feeding site on leaves, shoots or fruit. Occasionally they can be blown by the wind into neighbouring trees or orchards. The crawlers lose their legs a day or two after hatching, settle down and become immobile, and secrete a waxy white cover. After a couple of days the form is that of a cap with a flat top, thence the common designation at that period of "whitecap" (Willard, 1973; Rosen and DeBach, 1979).

Once a crawler settles, it inserts its mouthparts (rostrum) into the plant and starts feeding on the sap. The red scale remains fixed in position through its life, except that the winged male finally emerges. The insect becomes circular and revolves about for the purpose of properly molding the covering. Few days later, it forms a hard reddish-brown cover that is separate from the scale's body. After a period of feeding and growth the insect moults. The cast skin is attached to the scale cover, giving the cover its typical red colour. During this dormant stage, the rostrum keeps inside the body of the scale and separation of the body and the cover is impossible (Ebeling, 1959; Forster et al., 1995).

After the first molt, it is possible to distinguish between the sexes. The cover of the male scale becomes more elongated, smaller and paler than that of the female. Male scale completes three distinct immature stages, second instar male, pre-pupal and pupal stage under a scale cover, before emerging as a delicate, winged insect. The male is orange-yellow and has a wing expanse of $1.5 \mathrm{~mm}$. It is a frail weakflying insect but one pair of wings, the second pair being replaced by a pair of hooked halteres. It is attracted to the female by a pheromone, and dies without feeding after mating. All males are dead within 14 hours after emergence (Tashiro and Beavers, 1968).

With each molt the female cover develops a concentric ring around the nipple-shaped center. Upper completion of the second molt the insect again extends its covering until there is a wide gray margin of the covering extending beyond the insect body. The scale cover of the adult female is about $2 \mathrm{~mm}$ across. Adult red scale has a thin, circular, leathery covering over the soft, flattened, reniform shaped, creamy-yellow insect. It is during this period that fertilization occurs. The insect may live in the gray adult stage at least six months if fertilization does not occur. 
Thus, the female CRS life stages are crawler, first instar, first molt, second instar, second molt, third instar and mature females (Chart 1. 1). The distinguishing attributes of the stages are the rounded edges of the insect body under the cover, the body coloration and the ability of the cover and scale body to be separated (Forster et al., 1995) (Fig. 1. 5 and Fig. 1. 6).

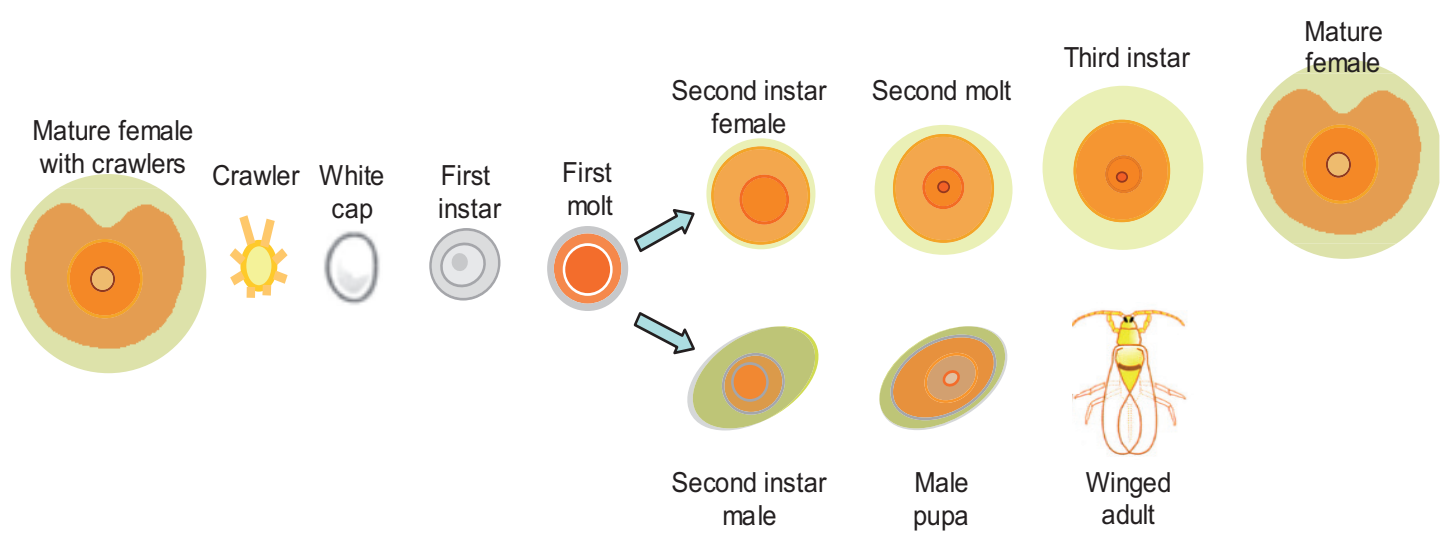

Chart 1. 1. Scale cover forms of the California red scale male and female development stages.

Fig. 1. 5. Up, cover and body of a young female stage (or virgin third instar) and down, cover and body of a male pupa stage of California red scale.
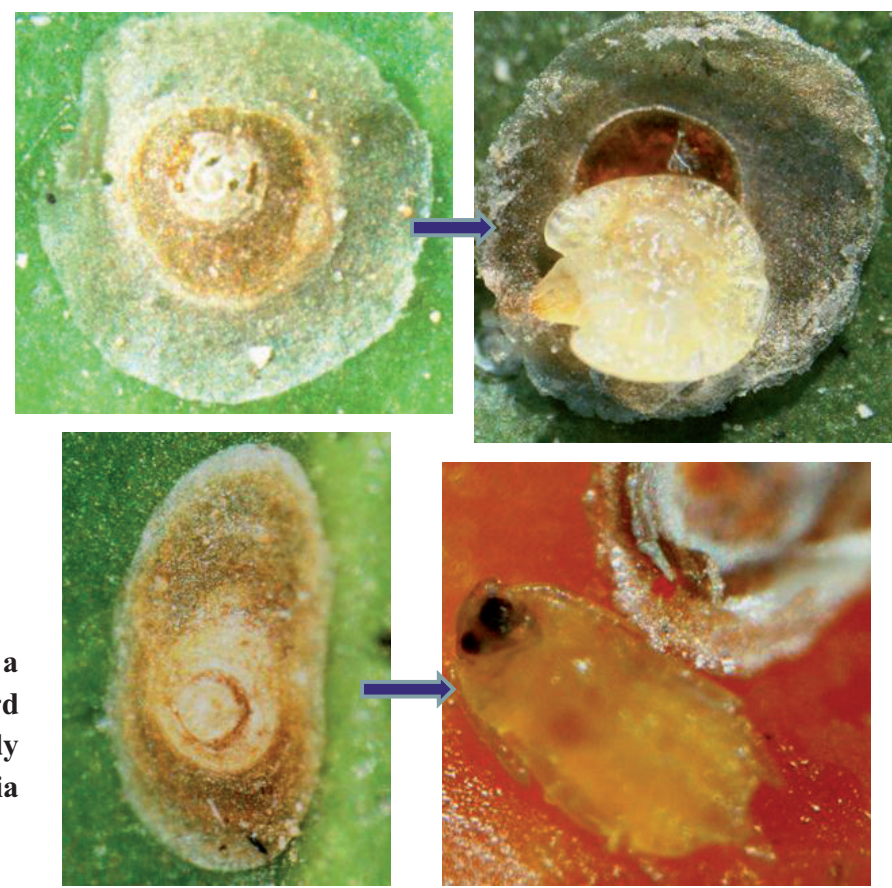

$-9-$ 

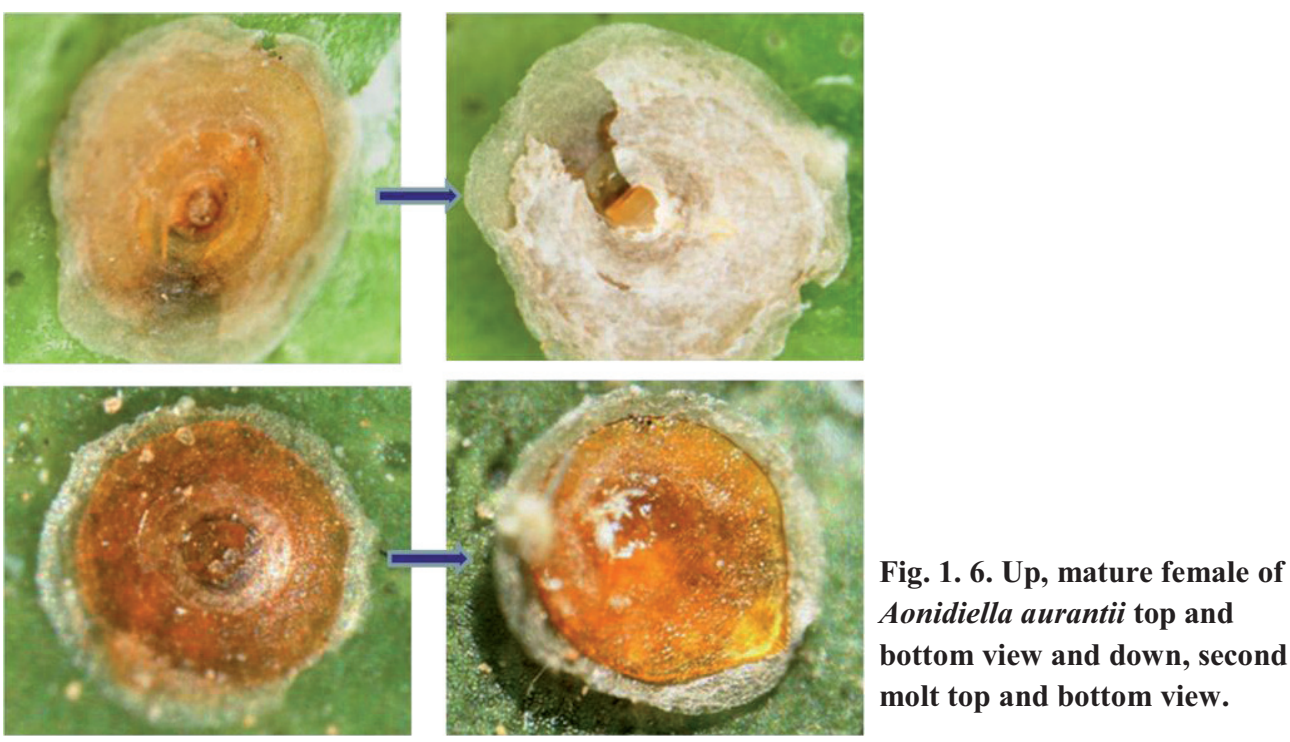

\subsubsection{Life cycle}

The development rate of CRS and the number of generations per year is closely correlated to the climatic conditions, mainly temperature and relative humidity. There may be between two to six generations per year (Quayle, 1941). The threshold development for CRS is estimated in about $12^{\circ} \mathrm{C}$ (Kennett and Hoffmann, 1985; Grout et al., 1989).

The mean number of days spent by the females in the various instars and molts was estimated by Nel (1933) on a wide range of temperatures. Those were 13.0 days for the first instar; 3.4 days for the first molt; 8.6 days for the second instar; 3.6 days for the second molt and 60.3 days for the third instar up to the time of reproduction. Forster et al. (1995), estimated the average mean number of degree days in the various instars as follows: $55^{\circ}$ days (degree days) for the first instar, $92^{\circ}$ days for the first molt, $112^{\circ}$ days for the second instar, $52^{\circ}$ days for the second molt and $158^{\circ}$ days for the third instar.

The period from crawler to crawler for red scale females on leaves outdoors at South Africa varies from 61 days (in mid-summer) to 138 days (in winter) according to Stofberg (1937). In laboratory conditions at $27^{\circ} \mathrm{C}$ a female scale takes 
approximately 47 days to develop from crawler to a mature, crawler-producing female (Luck, 1995). Kennett and Hoffmann (1985) established the average period of time required for CRS to complete the whole cycle in about 615 DD (growing degree days) using $11.7^{\circ} \mathrm{C}$ as threshold development for the scale. Similarly Forster et al., (1995) estimated the average degree days for CRS cycle in $650 \mathrm{DD}$, Murdoch et al., (1995) in $652 \mathrm{DD}$, Tumminelli et al. (1996) in $603 \mathrm{DD}$ and Asplanato and Garcia-Marí (2001) in 667 DD.

The crawlers can disperse on the tree walking up to $50 \mathrm{~cm}$ in distance but dispersion by the wind can reach big distances. Most crawlers fix within few hours. Birds, insects, other animals and humans can also be responsible of its dispersion (Ebeling, 1959; Bodenheimer, 1951). The specimens living on fruits mature faster and have higher survival rates than CRS reared on wood, whereas leaves and green twigs present intermediate values (Carroll and Luck, 1984).

\subsubsection{Distribution}

The California red scale is widely distributed in many parts of the world, in particular the tropics and subtropics. The origin is believed in the Oriental region (Bodenheimer, 1951). In the Mediterranean basin, CRS has been a serious pest for many years in eastern countries. The first recorded infestation was in 1926 in Palestine, and later on it was also found in Greece, Cyprus, Turkey, Syria, and Egypt (Bodenheimer, 1951). During the first part of the 20th century it was described as the most important pest of citrus in Australia, California, South Africa, Mexico by Quayle (1941). It slowly expanded to the eastern Mediterranean basin during the second half of the 20th century (Delucchi 1965, Liotta 1970). In his book, one of the earliest and most exhaustive studies on citrus pests, Quayle (1941) stated that CRS prefers a semiarid climate like that of California and South Africa rather than a humid climate like that of Florida and he was predictive on referring Spain, Italy and northern Africa as potential areas of spreading of CRS when Chrysomphalus dictyospermi (Morgan) was the dominating species. Nowadays A. aurantii has extended to all these citrus regions where it is considered as the more important citrus pest whereas $C$. dictyospermi has almost disappeared (Siscaro et al., 1999; Guirrou et al., 2003; Soto et al., 2008). 
Bodenheimer (1951) extended the list of countries where CRS was a serious pest to Kenya, Madagascar, Zanzibar, Mauritius in Africa, Argentina, Chile, Paraguay, Uruguay and Brazil in South America, India, Siam, Philippines, Formosa in Orient and Greece, Turkey, Syria, Cyprus, Egypt and Italy in the Mediterranean. In that period however CRS was still not present or extremely rare in Spain, France, Lybia, Tunisia, Morocco and Algeria.

In the Oriental region, the original environment of the red scale, CRS is widely extended in citrus areas of China, Taiwan, India, Japan and some others but at lower densities than in regions were CRS is an invasive species (Flanders, 1971). Aonidiella aurantii has continued spreading to new areas, being now present in most citrus areas except those with tropical humid climate like central Brazil and Colombia. However, recently CRS outbreaks have also been reported in typical tropical climate citrus areas like Florida (Stansly, 2003) and the north of Perú (Elisabez Núñez, Servicio peruano de Sanidad Agraria, personal communication)

(Chart 1. 2).

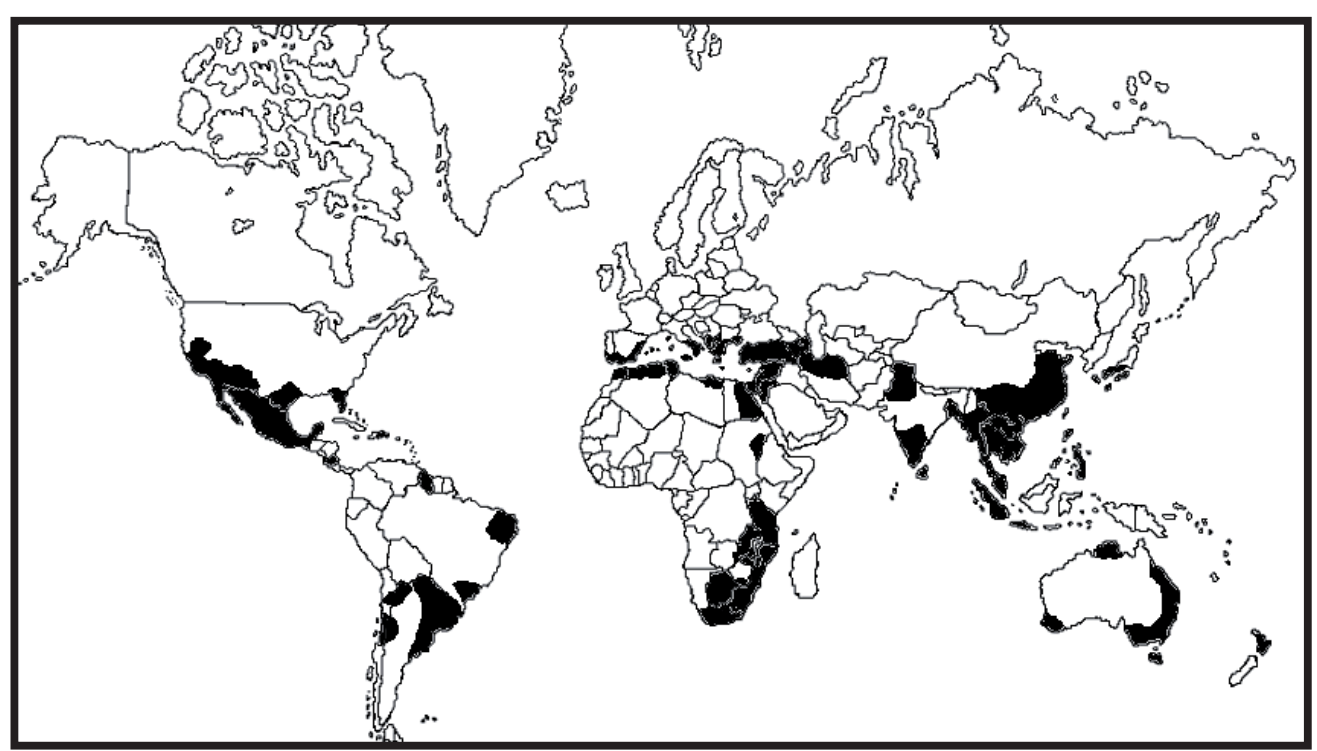

Chart 1. 2. California red scale world distribution map (based on Flanders, 1971; Viggiani, 1988; Claps et al. 2001; Hill, 2008). 


\subsubsection{Integrated pest management}

The chemical control of $A$. aurantii is difficult, and is frequently followed by recurrent infestations. The reason has been related to the appearance of resistance to different products used for the CRS control and the elimination of the natural enemies present in the field. Populations of CRS developed resistance to organophosphate and carbamate insecticides in California, South Africa, Israel and Australia (Forster et al. 1995; Bedford, 1996; Levitin and Cohen, 1998; Collins et al., 2007). Several experiments demonstrated that CRS develops resistance to chlorpyrifos and methidation (Grafton-Cardwell et al., 2001; Vehrs and GraftonCardwell, 1994; Martínez et al., 2005). An alternative approach to chemical control is through an integrated pest management (IPM) strategy. This strategy attempts to minimize the use of pesticides and focuses on preserving existing and introducing missing insects and mites that will biologically manage citrus pests.

Because of the relatively high susceptibility of armoured scales to suppression strategies with natural enemies, they are effectively controlled using IPM approaches (Flint, 1991). The IPM may include the combination between insectary-reared parasitoid releases and, in years when biological control is less effective, selective narrow range petroleum oil sprays during the summer to help reduce scale numbers. Releases of parasitoids should be focused mainly in spring and early summer to augment the low number of natural enemies that attack CRS populations in this period (Sorribas et al., 2008). The IPM approach involving augmentative biological control has demonstrated its value to the management of CRS in California citrus (Luck, 2006)

Pheromone traps are available for monitoring CRS populations. The most commonly used is a yellow or white sticky card, to which a rubber cap impregnated with the female sex pheromone is attached (Fig. 1. 7). These traps catch the adult males as they fly in search of females. With a knowledge of the expected period of time between mating and hatching of nymphs, these traps can give an idea of when parasitoid releases or selective narrow range oil treatments may be most effective. Else they can give an idea about the convenience or not of treatments, since as suggested by Hernández et al. (2002) groves in which daily captures on sticky traps are lower than 10 CRS males do not require treatments as the economic threshold of injury is not reached. 


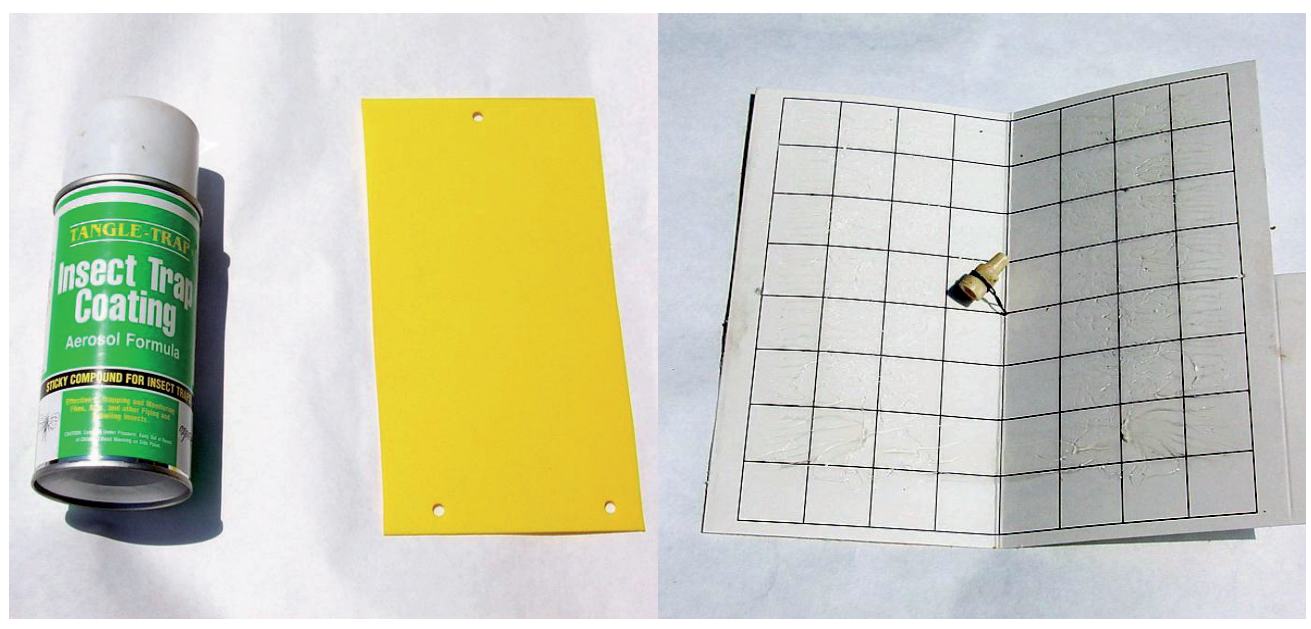

Fig. 1. 7. A sticky spray, a yellow card and a white sticky card with a sex pheromone cap attached. They are utilized for monitoring red scale populations in the field.

Else, pheromone traps, as well as several colour traps, are known to be effective in catching CRS parasitoids (Sternlicht, 1973; Moreno et al., 1984). Therefore, they can give an idea about existing parasitoid species and their relative population compared to CRS males captured.

On the other hand, their unique life style appears to make armoured scale insects more amenable to biological control by natural enemies than are other groups of injurious organisms. Hence, it is essential to encourage CRS parasitoid and predator action by the study of the existing species and the periods of the year they are more abundant in order to look for complementary species for releases. In fact, the negative effects of some chemicals, like pyridaben, methidation or carbaryl, on parasitoid populations has been associated to the increase of CRS densities up to 15 times that of the untreated controls (Cardwell and Reagan, 1999; Stansly, 2003). 


\section{2. Biological control of $A$. aurantii}

Biological control of invasive pests through the introduction of parasitoids has been practiced for many years in cultivated systems. The biological control was conceived and developed by entomologists against insect pests (DeBach and Rosen, 1991). Nnatural control is defined as the maintenance of population numbers within certain upper and lower limits by the action of the whole environment, necessarily including an element that is density-induced (Doutt and DeBach, 1964). Any organism that feeds on another organism is, by definition, a natural enemy. That includes parasitoids, predators and pathogens.

It is rare the pest that has no one or more parasitoids and predators (DeBach and Rosen, 1991). The more reliable, efficient regulating predator or parasitoid is one that has a reciprocal density-dependent relation with its host or prey. That is, the host is regulated by its enemy, and its enemy in turn is limited by the number of hosts (Huffaker and Messenger, 1964). Biological control rests on the premise that the densities of many noxious species are amenable to control, probably regulation, largely by their natural enemies. Empirical evidence and theoretical considerations seem to favour parasitoids over predators as they are more host-specific, more closely adapted and synchronized in interrelationship, their lower food requirements allow them to maintain a balance with their host at a lower host density and the young stages do not have to search for their food (Doutt and DeBach, 1964).

Both parasitoids and predators are the most important natural enemies of California red scale. The parasitoids complete their development on a single host, whereas a predator consumes several prey individuals during its development. Both adults and young of many predatory species feed on the same prey species, whereas entomophagous parasitoids search for hosts only as adults and the adult does not kill the victim, but instead deposits an egg in or on it (Huffaker et al. 1971).

Events leading to the biological control of CRS mark one of the most thorough and scientific approaches in biological control. The origin of the biological control of $A$. aurantii constitutes a classical example of the necessary steps prior the establishment of beneficial species to control an insect pest. During 1889-1947 a variety of exotic natural enemies were introduced into California for CRS control, 
the earliest efforts emphasizing introductions of coccinellid predators, of which more than 40 species were imported to the US (Compere, 1961). Most failed to established and attention was then given to parasitoids. Big efforts with poor media were carried since 1940 to find parasitoids in the area of origin of the pest (Flanders, 1943; Smith, 1942).

The high number of papers dealing with CRS parasitoids that was published until 1955 are explained by the large expansion and important economic impact of the pest which in this period presented a low number of natural enemies. Finally, after unsuccessful attempts of introduction of many natural enemies, Paul DeBach et al. (1955) stated the bases of the biological control of CRS. As he assessed, the biological control of the pest was possible under certain circumstances through the combination of different parasitoids. This is also considered as the longest campaign in the history of biological control (Kennett et al., 1999).

The main methods of augmenting natural enemy populations on biological control techniques of CRS are importation, augmentation and conservation. The importation of exotic natural enemies is the most promising as this has been demonstrated repeatedly by successful biological control projects on CRS. For instance, importation of CRS parasitoids and predators has demonstrated to reduce the scale population in citrus-producing areas of California, Australia or South Africa (DeBach, 1969; Smith, 1978; Furness et al., 1983; Bedford, 1998) Augmentation of parasitoids or predators involves their direct manipulation usually by mass production and periodic colonization. Conservation of established natural enemy species involves manipulation of the environment to favour such species, either by eliminating or mitigating adverse factors, such as the elimination of ants, or by providing lacking requisites, such as nectar and honeydew providing plants (Rosen and DeBach, 1979).

\subsubsection{Classification of parasitoids}

Parasitoids are insects whose females lay their eggs in or on other invertebrates and whose larvae feed on the host and eventually kill it (Jervis et al. 2001). Based on egg allocation and larval developing system there are different types of parasitoids. Idiobiont parasitoids are those that prevent further development of the host after initial parasitization; this typically involves a host life stage that is 
immobile (e.g., an egg or pupa), and almost without exception, they live outside the host. Koinobiont parasitoids allow the host to continue its development and often do not kill or consume the host until the host is about to either pupate or become an adult; this therefore typically involves living within an active, mobile host. Koinobionts can be further subdivided into endoparasitoids, which develop inside of the prey, and ectoparasitoids, which develop outside the host body, though they are frequently attached or embedded in the host's tissues. It is not uncommon for a parasitoid itself to serve as the host for another parasitoid's offspring. The latter is termed as secondary parasitoid, or hyperparasitoid; most of such species known are in the insect order Hymenoptera (Godfray, 1994; Thompson, 1999)

Both ectoparasitoids and endoparasitoids can be either solitary (when only one larva develops per individual host) or gregarious (when more than one larva develops upon a single host (Fig. 1. 8). Parasitoids may have one generation (univoltine) to one generation of the host or two or more generations (multivoltine) to one of the host. When females emerge with a reduced number of ovarian eggs and more eggs are produced along its life it is named as synovigenic, whereas proovigenic females complete oogenesis prior to eclosion and generally lay their eggs soon after emergence. Proovigenic parasitoids most often develop as koinobiontic endoparasites, developing in hosts that survive and continue to feed and grow following parasitism (Godfray, 1994; Quickie, 1997).

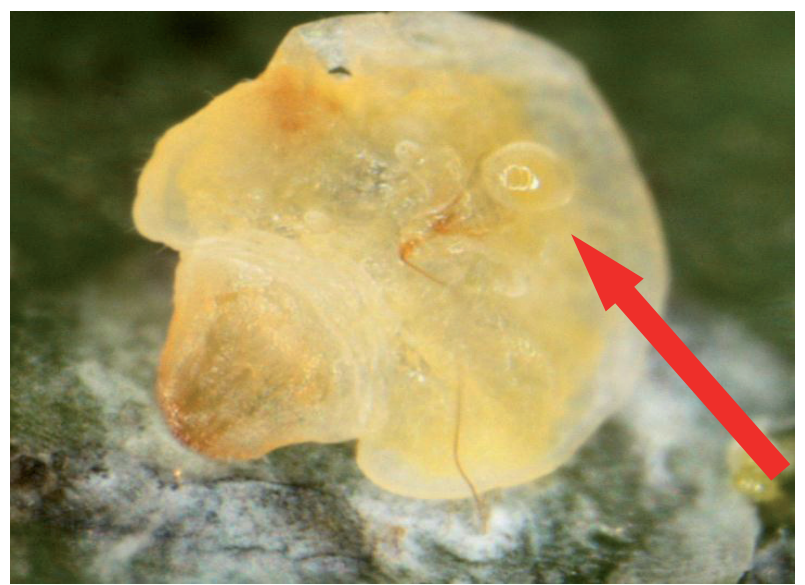

Fig. 1. 8. A solitary egg of an ectoparasitoids species attached to the bottom part of the body of a young female scale. The rostrum of the scale connected to the plant tissue can be also observed. 
Synovigenic parasitoids offer an ideal opportunity to study how insects manage their larval and adult resources. These parasitic wasps mature eggs during their entire adult lifetime. Females lay their eggs in or on the bodies of their hosts and feed off them as they develop. The host is also the main source of nutrients for the foraging female (Jervis and Kidd, 1986; Heimpel and Collier, 1996; Jervis et al., 2001).

Ectoparasitoids are by far the most important natural enemies of the armored scale insects. All known ectoparasitoids of CRS are members of the large genus Aphytis (Howard) (Rosen and DeBach, 1990).

\subsubsection{Ectoparasitoids of A. aurantii: Aphytis Howard}

The species of the genus Aphytis (Hymenoptera: Chalcidoidea: Aphelinidae) are minute, yellow or grayish wasps usually not exceeding one millimeter in length. They develop exclusively as primary ectoparasitoids of armored scale insects (Rosen and DeBach, 1979).

The adult Aphytis female pierces the shield of the scale with the ovipositor and lays one to several eggs on the body of the scale insect. Protected by the covering scale, Aphytis larvae feed externally by sucking the body fluids from the scale insect. When larva is fully grown several characteristic meconial pellets are excreted and pupate underneath the empty scale. The adult parasitoid usually emerges through a hole chewed in the covering scale, but they may merely push their way out under the edge (Rosen and DeBach, 1979).

Aphytis females oviposit only in hosts whose body is free beneath the scale cover. Molt stages are not accepted as hosts because their body becomes attached to the cover and also because their tegument becomes heavily sclerotized and is too hard to be pierced by the ovipositor. Similarly, mature, mated females of CRS are not accepted as hosts by Aphytis (DeBach, 1969; Baker, 1976; Forster et al., 1995).

About 105 species of Aphytis have been described (Rosen, 1994). Most species of Aphytis are biparental, however, a relatively high proportion is uniparental. The biparental species exhibit arrhenotokous reproduction, unfertilized eggs developing into males and fertilized eggs into females. Unmated females 
produce male progeny, whereas mated female produce both sexes. The uniparental species of Aphytis exhibit thelytokous parthenogenesis, female producing female progeny without fertilization by males. However, males are produced regularly in these species at a very low rate (Doutt, 1959; Rosen and DeBach, 1979). Thelytoky of several of these Aphytis species has been associated to the presence of Wolbachia, a bacteria genus that induces parthenogenesis reproduction on Aphytis (Zchori-Fein et al., 1994; Werren et al., 1995; Gottlieb et al., 1998; Pina, 2006).

As natural enemies, the species of Aphytis are generally superior in effectiveness to the endoparasitoids and predators of armored scale insect and for this reason several species have been successfully employed in biological control projects (Rosen, 1994). Naturally occurring species of Aphytis are responsible of keeping the populations of many potential pests at subeconomic levels and they are the most effective natural enemies controlling CRS (Rosen and DeBach, 1979).

\subsubsection{Life history of Aphytis}

The eggs of Aphytis are deposited underneath the scale cover where they adhere to the surface of the host by means of a small adhesive pad. The deposited egg is stalked, whitish, with a semitransparent chorion (Fig. 1. 9a). Aphytis females lay their eggs on either the dorsal or the ventral side of the host body (Abdelrahman, 1974b).

Aphytis have three larval instars (Fig. 1. 9b). Toward the end of the larval period, the third-instar larva enters a short prepupal stage. All feeding ceases and the larva excrete fecal material in the form of several brown or black meconial pellets. The prepupa is usually milky white (Fig. 1. 9c). It then enters a resting period, during which a rapid metamorphosis takes place. Differentiation of pupal structures becomes evident with the appearance of pupal mouthpart, legs and wing cases. The pupa of Aphytis is exarate, flattened dorso-ventrally and wider than thick. The antennal cases are present on each side of the head. The sexes are recognizable in this stage. The eyes of the developing pupa gradually turn from colourless to red and to green (Fig. 1. 10) providing an indication of the age of the pupa (Eliraz and Rosen, 1978; Rosen and DeBach, 1979). 
(a)

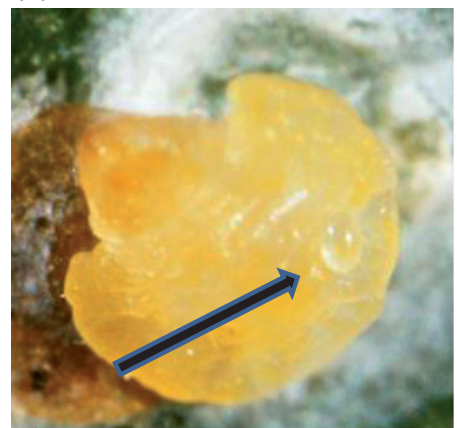

(b)

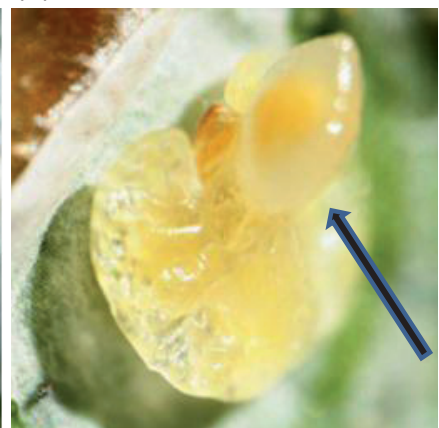

(c)

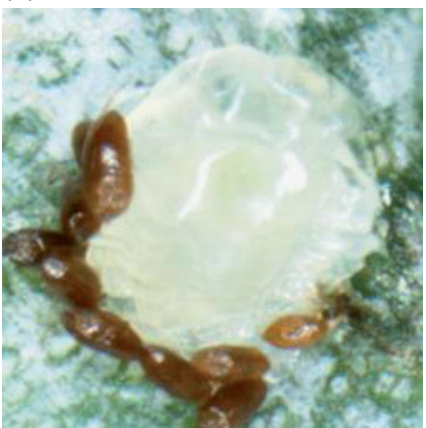

Fig. 1. 9. Egg (a), larva (b) and prepupa (c) of Aphytis spp. In the prepupal stage the meconial pellets have been excreted.

(a)

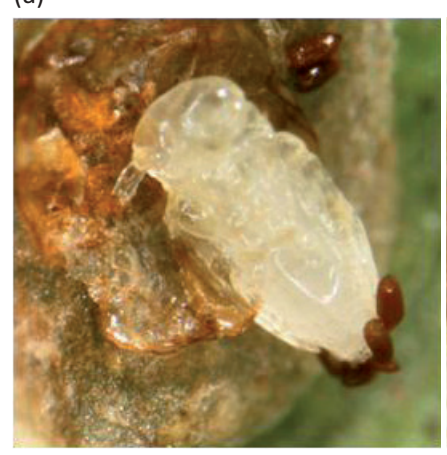

(b)

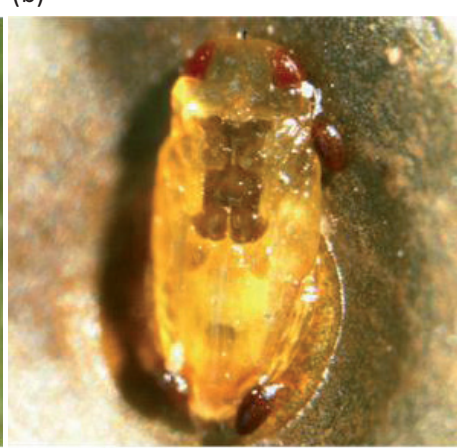

(c)

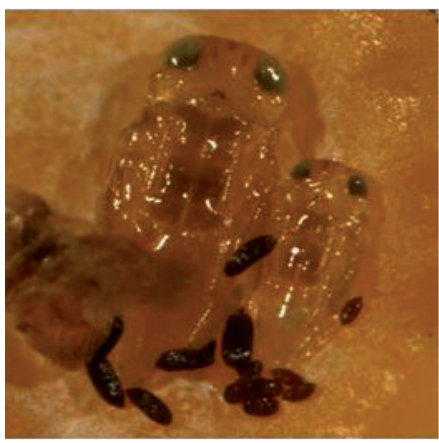

Fig. 1. 10. White (colourless) (a), red (b), and green (c) eyes on pupae of Aphytis species, an indicator of the age of each pupa.

Eclosion occurs underneath the covering scale of the host. Emergence from the host is usually effected by chewing an exit hole through the covering scale. At room temperature, the entire process may take about 30 minutes. Long after emergence, the distinctive meconia and characteristic exuvia, as well as the oval exit hole when present, are the unmistakable signs attesting to the fact that a dead armored scale insect had earlier been parasitized by Aphytis (Rosen and DeBach, 1979).

The development period of the different Aphytis species is much shorter than the host and depends on climatic conditions, mainly temperature and humidity ( $\mathrm{Yu}$ and Luck, 1988). The parasitoid can complete up to three generations for each scale 
generation. Most species are multivoltine; they develop continuously throughout the year (Murdoch et al., 1995).

Aphytis are idiobionts, before oviposition the female paralyzes the host by inserting venom through her ovipositor (Lenteren, 1994). The scales stop rotating when parasitized (Fischer, 1952). Most Aphytis species are facultativey gregarious, larger scale may receive more than one egg (Luck et al., 1982). Aphytis female emerges with zero or few eggs which develop and mature in the ovaries continously through its life. Thus, it is considered a synovigenic species (Rosen and DeBach, 1979; Opp and Luck, 1986).

Aphytis oviposit only in hosts whose body is not attached to the cover, i.e. they avoid parasitizing molt stages. Similarly mature females are not accepted as host as they are heavily sclerotized (DeBach and White, 1960; Forster et al., 1995). In biparental species male offspring result from unfertilized and female from fertilized eggs. Most Aphytis female come from larger instar hosts (Luck and Podoler, 1985; Opp and Luck, 1986). Also in biparental species, temperature has been found to affect the offspring sex ratio. At lower temperatures the sex ratio turns male biased (Rosen and DeBach, 1979; Kfir and Luck, 1979). Sex ratio is also affected by host size. Females usually allocate female eggs to large hosts and male eggs to small hosts (Charnov et al., 1981; Luck et al., 1982; Luck and Podoler, 1985; Yu, 1986). Females can control the sex of their offspring at oviposition via haplodiploidy producing unfertilized eggs to generate sons or fertilized eggs to generate daughters (Flanders, 1953; Rosen and DeBach, 1979).

Temperature and humidity have strong effect on Aphytis survival. Extreme temperatures are considered the main factor of mortality for Aphytis in the field (Rosen and DeBach, 1979). In the laboratory experiments of Kfir and Luck (1984) the combination of high temperatures with low humidity negatively affected adult Aphytis survival. In these experiments the life span of the adult Aphytis, provided with honey as food, ranged from 1 up to 14 days.

\subsubsection{Host-feeding}

Adult Aphytis wasps derive their carbohydrate nutrition in nature mainly from nectar and honeydew (Avidov et al., 1970; Heimpel and Rosenheim, 1995). 
However, like other synovigenic insects, the females require proteinaceous nutrition for continuous ovigenesis. This is obtained by predatory host-feeding by which the parasitoid feeds on the body fluids of the host (Forster et al., 1995). After drilling through the scale cover, the female thrusts the ovipositor into the body of the host. When the ovipositor is at last carefully withdrawn, a tiny strawlike feeding tube remains (Rosen and DeBach, 1979).

The host-fed scale develops large brown necrotic spots (Fig. 1. 11) and dies within several hours to a few days. However, mortality by host-feeding is rather difficult to quantify because host die and dry up and thus they cannot be distinguished from hosts that have died due to other abiotic factors. Certain host stages that are not acceptable for oviposition by Aphytis, such as first-instar and first molt stages are readily utilized for host-feeding (Abdelrahman, 1974; Heimpel and Rosenheim, 1995). Host-feeding is a typical ability of many synovigenic species (Jervis and Kidd, 1986).

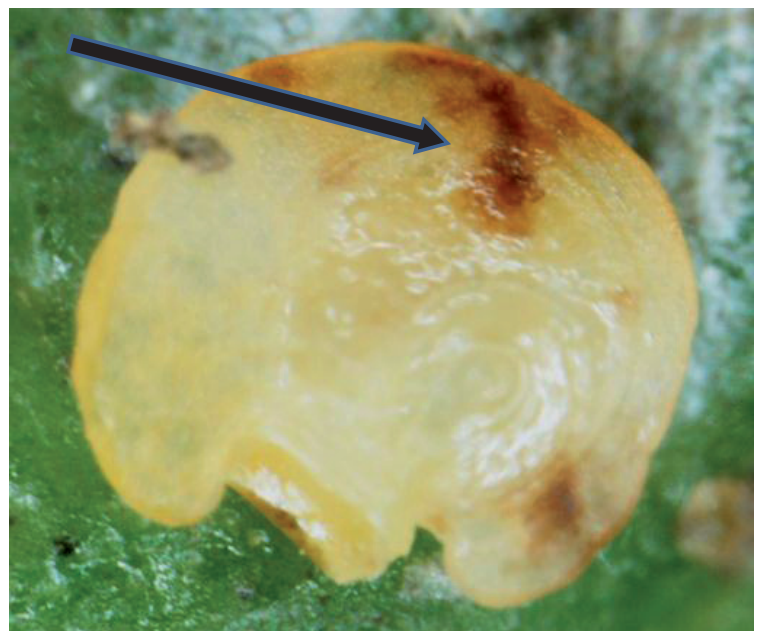

Fig. 1. 11. Necrotic spots caused by Aphytis host feeding on a young female scale.

\subsubsection{Main Aphytis species parasitizing $A$. aurantii}

The identification of Aphytis species is very difficult. The main taxonomic differences are based on the pupal pigmentation and the shape of the propodeal 
crenulae. Some other biological differences that can be useful for the separation of certain closely related species of Aphytis are the meconial pellets, the number of setae in the thorax, the proportions of antennal segments, the relative length of the ovipositor, the Yshaped suture of the mesosternum (Fig. 1. 12), the wing shape, the number of setae along the marginal vein and some others (Rosen and DeBach, 1979).

Fig. 1. 12. Adult of Aphytis with the Y-shaped suture of the mesosternum indicated by a circle.

\section{Aphytis melinus DeBach is}

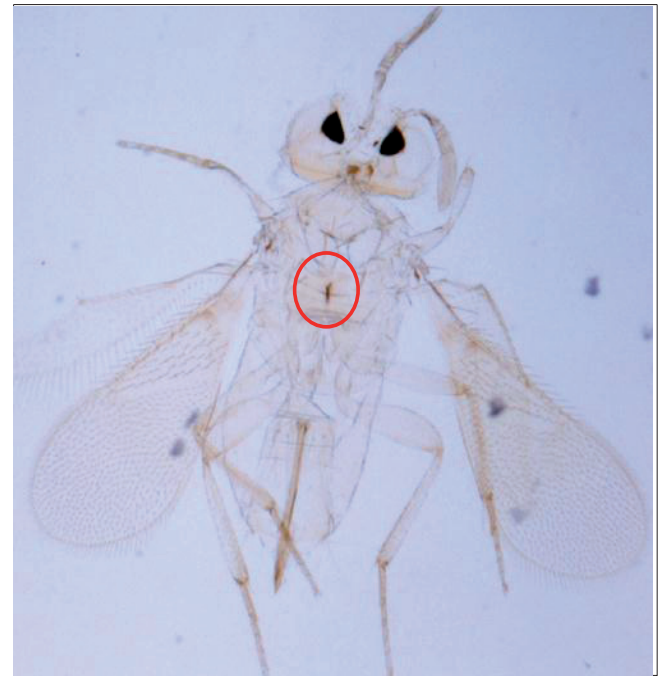

considered the most successful and widespread biological control agent of Aphytis micro-wasp genus (Murdoch et al. 1989, DeBach and Rosen 1991, Forster et al. 1995). Aphytis melinus (Fig. 1. 13) is considered a superior competitor in the field, very often displacing other previously existing Aphytis species, because it is better adapted to dry and hot climates (Rosen and DeBach 1979), it possesses superior intrinsic biological and physiological capabilities, exhibits a higher capacity of dispersion, and moves twice as fast when temperatures are higher than $16^{\circ} \mathrm{C}$ (McLaren 1976).
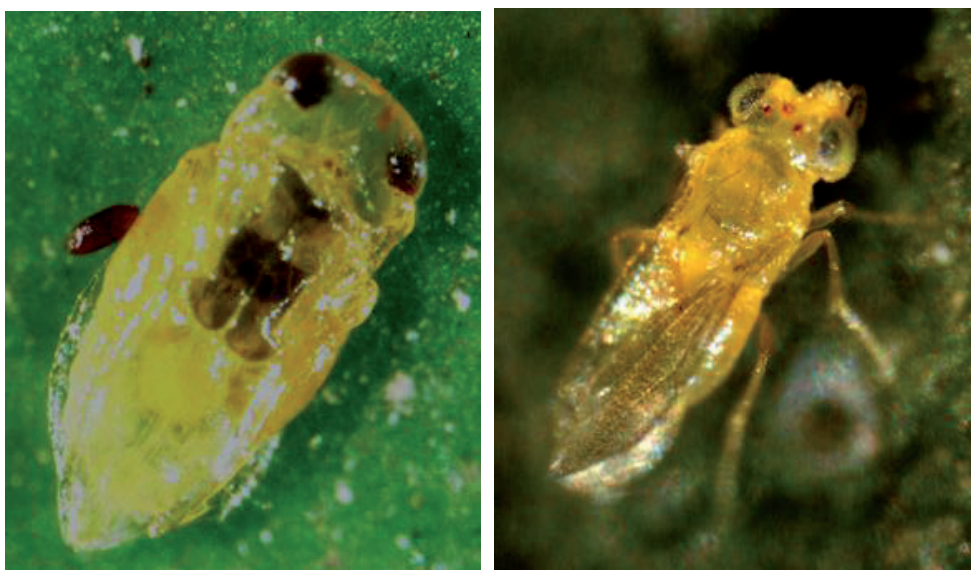

Fig. 1.13. Pupa of $A$. melinus with its characteristic rectangular brown pigmentation on the thoracic sterna (left) and adult of $A$. melinus (right). 
Being the most important CRS parasitoid, the biology of A. melinus has been widely studied. Development time for the different parasitoid instars, in degree-days, was calculated as average of several temperatures (Murdoch et al., 1995 ) as follows: $42.7^{\circ}$ days from egg to larva, $88.1^{\circ}$ days from larva to prepupa, $19.3^{\circ}$ days from prepupa to pupa and $93.4^{\circ}$ days from pupa to adult.

Aphytis melinus is native to northern India and Pakistan and has been used for the control of A. aurantii and Aspidiotus nerii Bouché since 1956 (Rosen and DeBach, 1978). It has been mass reared and released or accidentally introduced almost in all citrus areas where $A$. aurantii is present.

Aphytis chrysomphali (Mercet) was the commonest parasitoid of CRS in many citrus-producing countries before the introduction of A. melinus. It was generally distributed but it was not able to control the red scale populations (Quayle, 1941). Initially, the presence of A. chrysomphali (Fig. 1. 14) was reported in Spain, Turkey, California, Mexico, Cyprus, Morocco, Israel, Greece, South Africa, Australia, Argentina, Sicily (Italy), and some other citrus regions (Mercet, 1912; DeBach et al., 1955; Jiménez-Jiménez and Smith, 1958; Wood, 1963; Delucchi, 1965; Avidov et al., 1970; Pelekassis, 1974; Bedford and Grobler, 1981; Furness et al., 1983; De Santis and Crouzel, 1994; Siscaro et al., 1999).
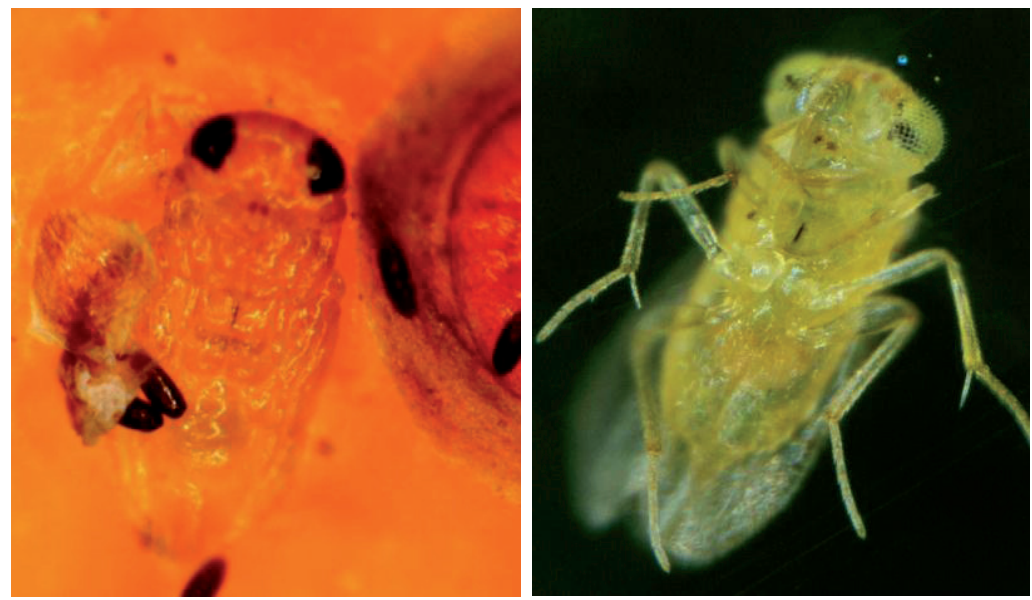

Fig. 1. 14. Pupa (left) and adult (right) of $A$. chrysomphali with the characteristic black transversal mark visible on the mesoscotum. 
Nowadays, after the introduction of the superior competitor A. melinus in these regions, A. chrysomphali remains present only in coastal citrus areas of Cyprus, Egypt, Australia, Uruguay, Spain and Mexico (Orphanides, 1984; Hafez, 1988; Dahms and Smith, 1994; Asplanato and Garcia-Marí, 2002; Pina and Verdú, 2007; Myartseva et al., 2010).

Aphytis lingnanensis Compere was successfully introduced in California (DeBach and Sundby, 1963) where nowadays it is the main parasitoid in coastal areas (Luck, 1995). It was also imported to Australia, becoming the main CRS parasitoid in the state of Queensland (Smith, 1978; Papacek, 2009) and to South Africa where it established in Lowveld areas (Dahms and Smith, 1994). Aphytis lingnanensis (Fig. 1. 15) is one of the main CRS parasitoids in several Latin American countries like Argentina, Uruguay, Chile and Mexico (De Santis and Crouzel, 1994; Asplanato and Garcia-Marí, 2002; Lavandero et al., 2006; Myartseva et al., 2010). Its establishment on the CRS has been also recorded in several citrusproducing countries of the Mediterranean basin like Cyprus and Egypt (Orphanides, 1984; Hafez, 1988).

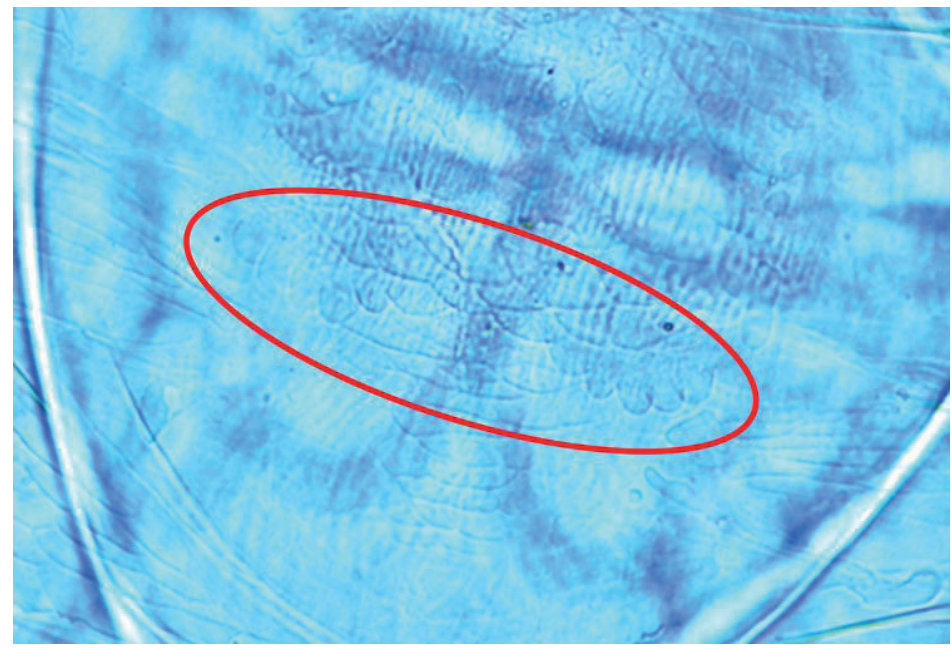

Fig. 1. 15. The main distinguishing taxonomic trait of the lingnanensis group, the propodeal crenulae large and overlapping is indicated by a circle.

Occasionally Aphytis hispanicus (Mercet) a common parasitoid of the "chaff scale" Paralatoria pergandii Comstock has been described as parasitoid of CRS 
(Rosen and DeBach, 1979; Pina and Verdú, 2007, Pekas et al., 2010b) (Fig. 1. 16). Other Aphytis species that have been described as parasitoids of A. aurantii are Aphytis africanus Quednau, which is considered as one of the main CRS parasitoids in South African citrus groves (Bedford and Grobler, 1981), and Aphytis coheni DeBach, which is the most important parasitoid in the warmer areas of Israel (Avidov et al., 1970) and was successfully introduced in Cyprus, Egypt and South Africa (Wood, 1963; Orphanides, 1984; Hafez, 1988; Bedford and Cilliers, 1994).
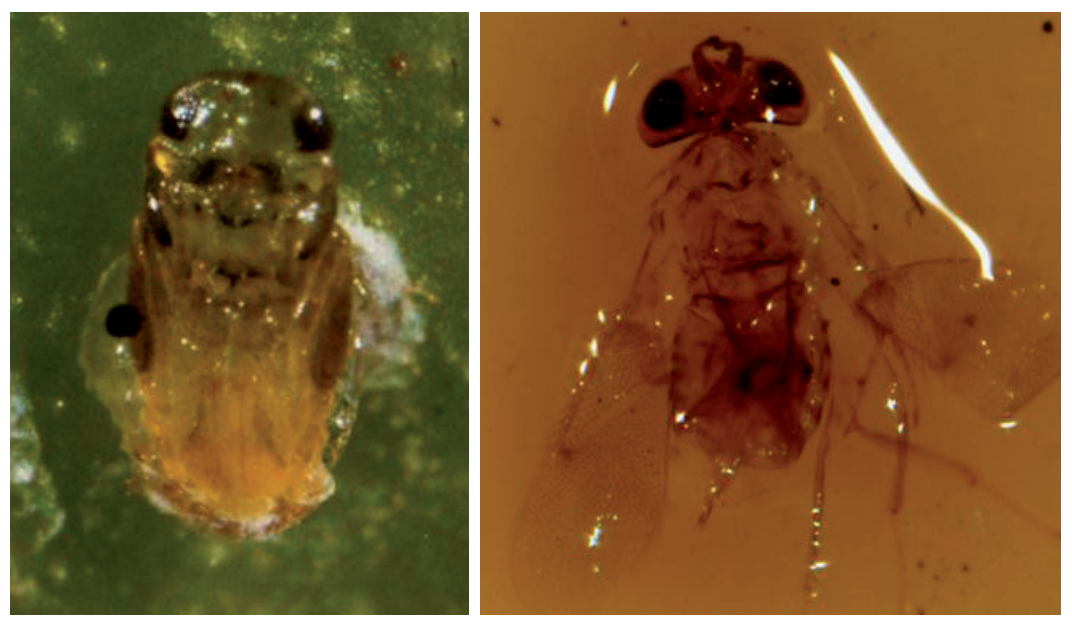

Fig. 1. 16. Pupa of $\boldsymbol{A}$. hispanicus found under a CRS scale cover (left) and adult of $\boldsymbol{A}$. hispanicus captured on a field yellow sticky trap (right).

\subsubsection{Ovipositional preferences by Aphytis species}

As it has been previously mentioned Aphytis can parasitize the scale instars in which the body is detached from the scale cover. However there are some differences between the main parasitoid species in the preferred CRS instars for parasitism and host-feeding.

Aphytis melinus utilizes a smaller threshold scale than A. lingnanensis. Else, the former can produce female offspring from smaller-size scale than $A$. lingnanensis (Luck et al., 1982; Luck and Podoler, 1985; Murdoch et al., 1996). Aphytis melinus allocates mostly male eggs to smaller host (from 0.15 to $0.4 \mathrm{~mm}^{2}$ ) 
while fertilized (female) eggs are laid on host larger than $0.4 \mathrm{~mm}^{2}$ (Luck and Podoler, 1985; Opp and Luck, 1986; Pekas et al., 2010b), while A. lingnanensis needs a minimum host size of $0.55 \mathrm{~mm}^{2}$ to produce female progeny (Luck and Podoler, 1985). In laboratory experiments, under a mean temperature of about $27^{\circ} \mathrm{C}$ and scales reared on lemon fruits, the sex ratio was favorable to A. melinus which produced $54-66 \%$ female in contrast to $35-37 \%$ produced by $A$. lingnanensis (Richardson, 1978; Luck et al., 1982; Abdelrahman, 1974b). However, when virgin females and males were held at $15.6^{\circ} \mathrm{C}$ for one day, the proportion of females was only $9 \%$ for A. melinus and $26 \%$ for A. lingnanensis (Rosen and DeBach, 1979). In the Valencia Region (Spain) field samples of A. melinus found higher or similar proportion of males than females (Troncho et al., 1992; Rodrigo et al., 1996; Pina, 2006; Pekas et al., 2010b).

Most Aphytis species are facultatively gregarious. The degree of gregariousness depends on host size but there are some differences between the species (Luck et al., 1982). From laboratory cultures of CRS on lemons it was found that $A$. melinus laid two eggs $57 \%$ of the visits to a red scale whereas $A$. lingnanensis laid two eggs $15 \%$ of the visits (Luck et al., 1982). However, in a recent study with field CRS infested branches and fruits only $8 \%$ of the parasitized scales developed two or more $A$. melinus and the proportion was lower (3\%) in the case of $A$. chrysomphali (Pekas et al., 2010b) which suggests a high mortality of immature stages of Aphytis.

Although first instar and first molt are not parasitized by Aphytis they are used as source of nutrients through host-feeding as well as second instars (Murdoch et al., 2005). Thus, only mature females and second molt stages are free from Aphytis attacks (Fig. 1. 17). Young Aphytis females with few mature eggs are more likely to feed on an encountered scale (to obtain nutrients for future egg development) than to parasitize it (Collier et al., 1994).

Aphytis melinus prefers to parasitize mainly big third instar scales (Forster et al., 1995). The majority of the offspring $(57 \%)$ is generated from third instar females with body sizes larger than $0.33 \mathrm{~mm}^{2}$ whereas A. chrysomphali produces its offspring mostly (66\%) from second instars males and females (Pekas et al., 2010b). Male scales and second instar female scales are infrequently used by A. lingnanensis and male wasps emerge when these instars are used (Luck and Podoler, 1985). 
Aphytis parasitoids detect and avoid ovipositing on hosts previously parasitized by a conspecific (Lenteren and DeBach, 1981; Luck et al., 1982) or previously parasitized by other Aphytis species (Luck and Podoler, 1985). However, A. melinus oviposits on hosts previously parasitized by endoparasitoids when they have been present in the host less than 7 days (Yu et al., 1990).

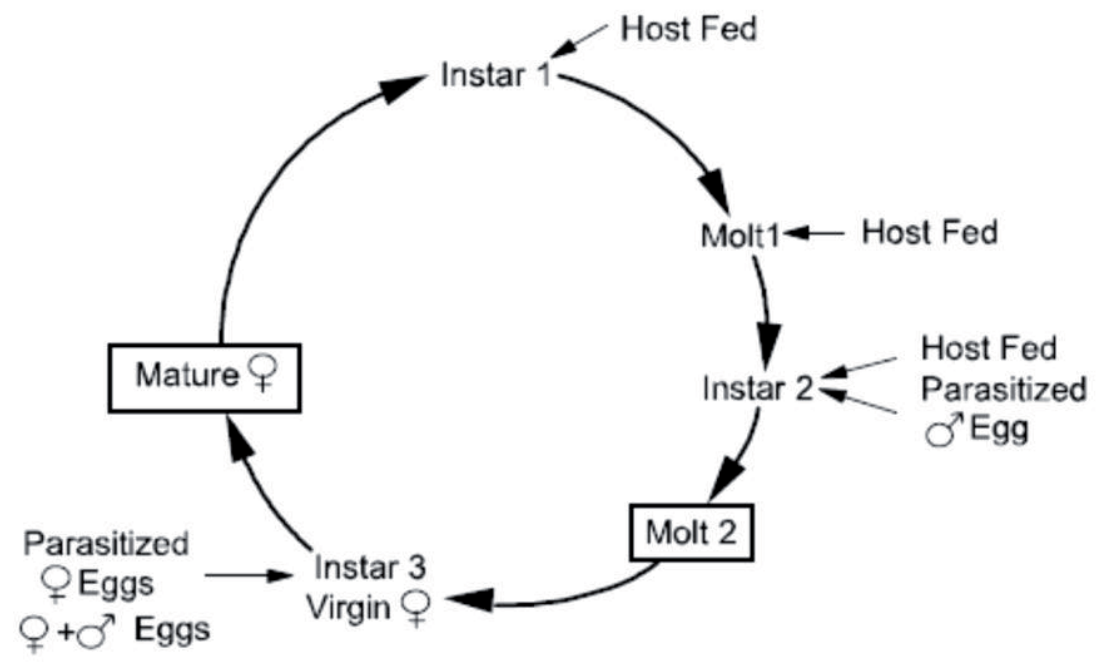

Fig 1. 17. Diagram of the patterns of parasitism and host feeding of Aphytis melinus in the different red scale stages (adapted from Murdoch et al., 2005).

\subsubsection{Endoparasitoids of $A$. aurantii}

Several endoparasitoids have been found to parasitize CRS, among them Encarsia perniciosi (Tower) and Comperiella bifasciata Howard are the most widespread in citrus areas all around the world. Both have been successfully introduced to control CRS in different citrus-producing countries. Other endoparasitoid species that have been described parasitizing red scale are Encarsia (=Asidiotiphagus) citrina Craw, Pteroptrix (=Casca) chinensis Howard, Pteroptrix wanhsiensis Compere, Habrolepis rouxi Compere (Flanders, 1971; Crouzel et al., 1973; Bedford and Grobler, 1981). However, little is known on these CRS endoparasitoids as compared to Aphytis species.

Curiously most of them, included E. perniciosi and C. bifasciata, are found in high numbers in Taiwan and China, believed to be origin of the CRS, where 
endoparasitoids seem to be as efficient in host regulation as Aphytis species. For instance, E. perniciosi is the dominant parasitoid in several regions of China with light CRS infestations and only P. chinensis successfully compete with it (Flanders, 1971). On the other hand, in contrast with Aphytis, a certain degree of encapsulation by $A$. aurantii has been described for all these endoparasitoids (Blumberg, 1997).

The coexistence of Aphytis and endoparasitoids can usually be explained by the fact that they are not strict ecological homologues (DeBach and Sundby, 1963). The endoparasitoids may attack first-instar larvae and molt stages which are not available to Aphytis.

\subsubsection{Encarsia perniciosi}

Encarsia (=Prospaltella) perniciosi is an Aphelinidae parasitoid that presents two main strains, the CRS strain and the San José scale strain. The red scale strain is a uniparental, thelytokous, solitary endoparasitoid whose females produce other females without mating and males are extremely rare. It can parasitize almost all red scale stages, but as its eggs and larvae are inside the scale body only Encarsia pupae (Fig. 1. 18) can be seen with binocular (Forster et al., 1995).
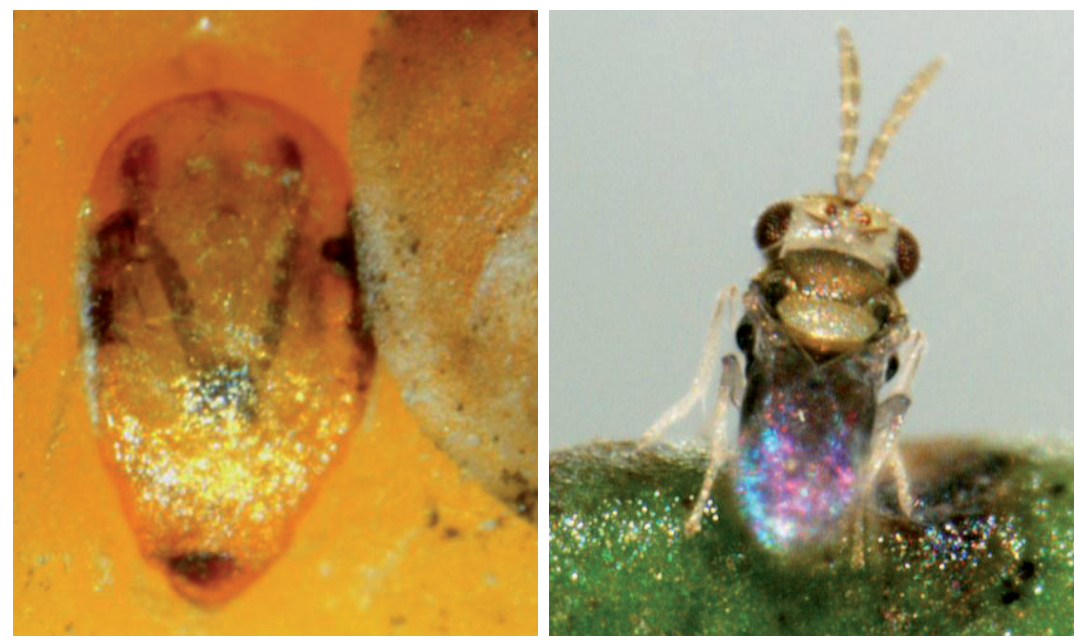

Fig 1. 18. Pupa of $E$. perniciosi visible under the exuvia of a male CRS (left) and adult of $E$. perniciosi (right). 
The parasitoid larva causes the scale's epidermis to harden and transform into a semitransparent case beneath the scale cover (mummy) visible when the parasitized scale is a second molt, third instar or mature female (Yu et al., 1990; Forster et al., 1995). The life cycle, from egg to adult, at $27^{\circ} \mathrm{C}$ takes $18-38$ days, depending on host size (Rosen, 1990; Yu et al., 1990).

Encarsia perniciosi begins its adult life with a full egg complement of about 32 eggs (Yu et al., 1990; Borer et al., 2004). It can successfully parasitize all red scale stages older than $55^{\circ}$ days, which is notably earlier than Aphytis species (Forster et al., 1995). Encarsia prefers scale on stems whereas Aphytis prefers those on leaves and fruits (Yu et al., 1990). Both E. perniciosi and A. melinus coexist in coastal California citrus groves (Forster et al., 1995; Borer et al., 2003).

Encarsia perniciosi has been successfully introduced against CRS in coastal areas of California, Australia, Uruguay, Italy and other citrus producing countries (DeBach, 1953; Yu et al., 1990; Smith et al. 1997; Siscaro et al., 1999; Asplanato and Garcia-Marí, 2002). This endoparasitoid is always outcompeted by A. melinus when both species parasitize the same host (Yu et al., 1990).

There are other species of Encarsia commonly found parasitizing armored scale insects different than CRS like E. brimblecombei (Girault), E. citrina (Craw), E. inquirenda (Silvestri) and E. aurantii (Howard). Some of them are very similar to E. perniciosi being necessary the study of taxonomic characters in the fore wing, the antenna (Chart 1. 3.) and the abdomen for the identification (Hayat, 1983; Viggiani, 1987; Polaszek et al., 1999; Myartseva, 2001)

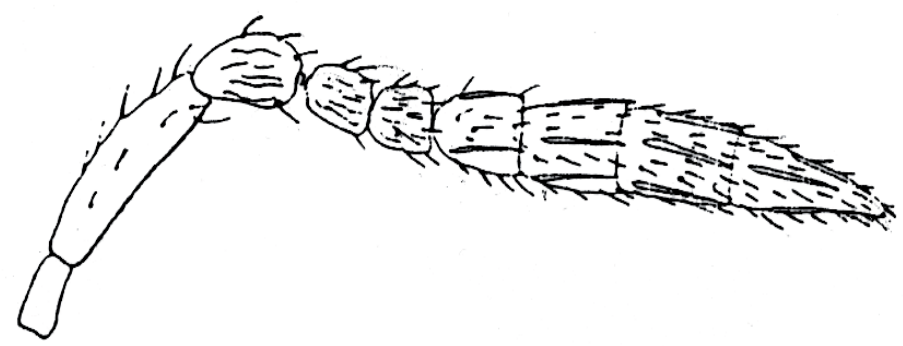

Chart 1. 3. Antenna of E. perniciosi, one of the main distinguishing taxonomic traits. 


\subsubsection{Comperiella bifasciata}

Comperiella bifasciata is an Encyrtidae endoparasitoid. Two strains or biotypes of $C$. bifasciata are known, the red scale strain and the yellow scale strain. The red scale strain originates from China and was imported, reared and released since 1942 in California and Australia (Smith, 1942; Flanders, 1944). If the yellow scale strain of $C$. bifasciata oviposits in A. aurantti, many of the eggs become encapsulated and parasitoids fail to develop (Brewer, 1971; Snowball and Sands, 1971; Blumberg, 1997). By contrast the red scale strain is able to parasitize up to $80 \%$ of adult female scales without significant encapsulation (Smith et al., 1997).

Comperiella bifasciata is a solitary, bi-parental endoparasitoid. Eggs are deposited in all stages of the female scale but development takes place in the advanced second instars and adult scales. Although C. bifasciata is solitary, ovipositing females frequently lay more than one egg per host during a single host visit (Blumberg and Luck 1990; Rosenheim and Hongkham 1996). At $27^{\circ} \mathrm{C}$ the duration from egg to adult takes on average 30 days (Flanders, 1944).

Sex ratio at $27 \pm 1^{\circ} \mathrm{C}$ and $50 \pm 5 \% \mathrm{R}$. H. was estimated in $55 \%$ of females (Richardson, 1978). Unmated females produce male progeny. It can parasitize almost all host stages of the red scale, but as its eggs and larvae are inside the scale body only C. bifasciata pupae (Fig. 1. 19) can be seen with binocular (Forster et al., 1995).
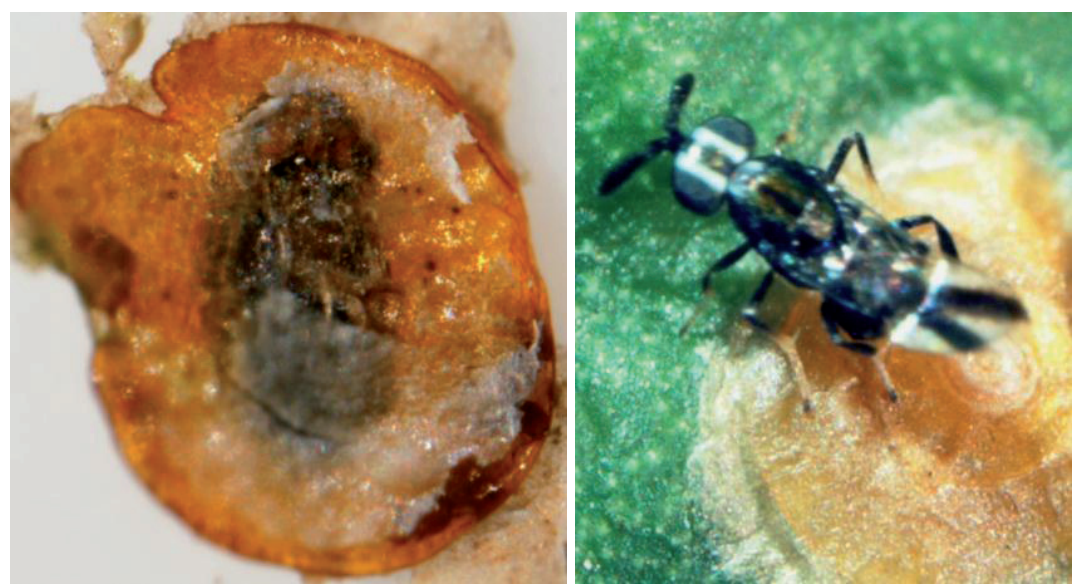

Fig. 1. 19. Pupa of $C$. bifasciata visible inside the body of a female CRS (left) and adult of $C$. bifasciata (right). 
Comperiella bifasciata is a common parasitoid in citrus areas of China and Taiwan being the main parasitoid in several inland areas (Flanders, 1971). The contribution of the introduced C. bifasciata to the successful biological control of CRS has been reported in citrus areas of California, France, South Africa, Israel, Syria, Turkey, Morocco and Italy (DeBach, 1948; Benassy and Bianchi, 1974; Bedford and Grobler, 1981; Viggiani, 1988; Sengonca et al., 1998; Guirrou et al., 2003; Siscaro et al., 2008). In California, C. bifasciata red scale strain was mass produced and released since 1941 (Flanders, 1943). In Australia, C. bifasciata was one of the first imported parasitoids in 1942 from China and it became widely established in the southern and eastern citrus areas (Furness et al., 1983; Smith et al., 1997).

As this endoparasitoid is common in inland citrus areas such as San Joaquin Valley (California) but it does not occur in the milder coastal areas, it is believed that C. bifasciata is better adapted to inland arid conditions (Richardson, 1978; Forster and Luck, 1996). The parasitism of C. bifasciata is particularly important on mature females of CRS, a stage not parasitized by Aphytis. In California citrus groves, $C$. bifasciata was able to reduce by more than one-third the density of scales that Aphytis missed (Luck et al., 1992). Well developed larvae of C. bifasciata are unacceptable to Aphytis but eggs and early immature stages are destroyed as a result of either host feeding or hiperparasitism by Aphytis (Richardson, 1978).

Both E. perniciosi and C. bifasciata have no necessity of host-feeding to obtain proteins for the production and deposition of eggs. This is possible because during their larval instars endoparasitoids have stored in their body a sufficient amount of proteins. Oviposition can be effectuated in a short time after adult emergence, conferring an advantage in relation to Aphytis species, mainly at low host densities as it would be difficult for Aphytis to obtain enough protein and then find new hosts (Flanders, 1971). 


\subsubsection{Predators of $A$. aurantii.}

Many species of artropods, either occasional or frequent, have been described as predators of CRS. Most of them are polyphagous that can feed on several preys, commonly other armored scale insects (Drea and Gordon, 1990). Predators are considered very effective on reducing heavy CRS populations that cannot be controlled by parasitoids as some of them are able to feed on mature female instars which are not parasitizable by Aphytis (DeBach, 1969; Samways, 1985; Siscaro et al., 1999).

\subsubsection{Coleoptera predators}

Various genera of Coleoptera Coccinellidae have been recorded as preying on armored scale insects. Chilocorus (Leach), Rhyzobius Stephens, Exochomus Redtenbacher, Coccidophilus Brethes and Scymnus Kugelann are the most commonly cited genera of predators on CRS (Meyer, 1962; Ricci, 1986; Drea and Gordon, 1990; Luck, 1995; Siscaro et al., 1999; Yarpuzlu et al., 2008, etc.). Other species of Coleoptera that have been described on A. aurantii belong to the genus Cybocephalus Erichson (Coleoptera: Nitidulidae) (Siscaro et al., 1999; Erler and Tunç, 2001).

Rhyzobius (=Lindorus) lophantae Blaisdell (Fig. 1. 20) is one of the most commonly introduced predators against armored scale pests. It has been imported or mass reared and released for biological control in citrus countries like Israel, USA, South Africa, Spain, Greece or Chile (Kehat er al., 1974; Honda and Luck, 1995; Bedford, 1998; Gómez-Vives, 1999; Stathas, 2000; Lavandero et al., 2006). In California, $R$. lophantae was introduced in 1898 and later it extended to other citrus regions of the United States (Quayle, 1941; DeBach, 1969; Honda and Luck, 1995). It has been also described as one of the main predators in citrus areas of Morocco, Cyprus, Australia, Argentina, Portugal, Tanzania, Italy and Turkey (Smirnoff, 1950; Wood, 1963; Furness et al., 1983; Ricci, 1983; Cardoso and Gomes, 1984; Katundu, 1988; Viggiani, 1989; Erler and Tunç, 2001). However it has limited efficacy as predator of CRS since it prefers to feed on mature female stages of the scale (Honda and Luck, 1995). 


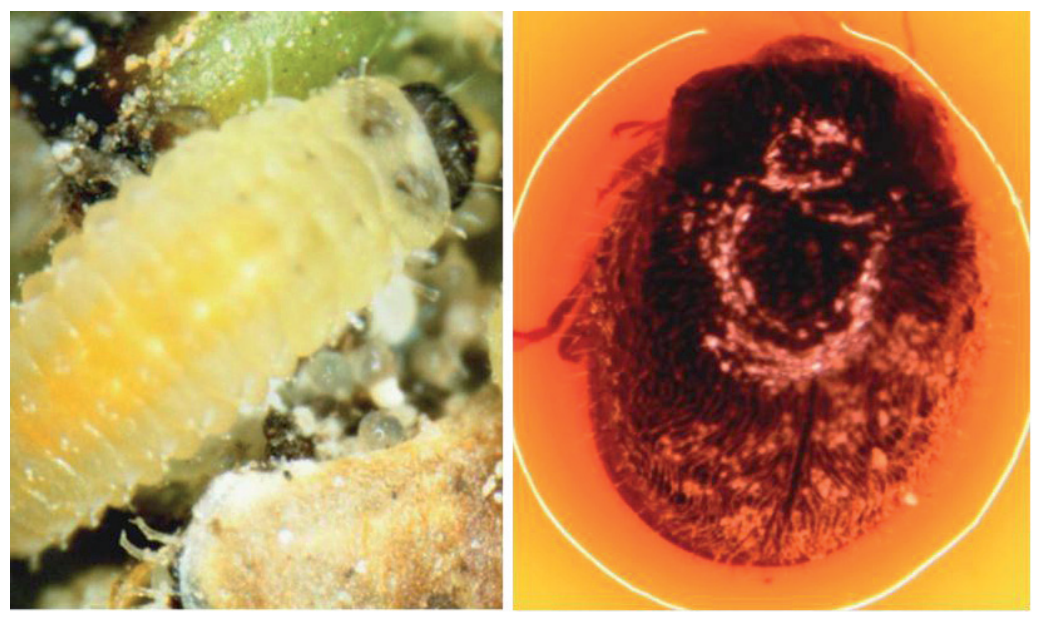

Fig. 1. 20. Larva of $\boldsymbol{R}$. lophantae searching for preys on a CRS colony (left) and adult of $\boldsymbol{R}$. lophantae captured in a yellow sticky trap (right).

Several species of the genus Chilocorus have been described as predators of CRS and many other armored scales. Probably the more extended is C. bipustulatus (L.) (Fig. 1.21) which is considered as one of the most important CRS predators in citrus areas of Spain, Cyprus, Israel, Argentina, Italy, Greece, Turkey and Egypt (Mercet, 1911; Wood, 1963; Ben-Dov and Rosen, 1969; Crouzel et al., 1973; Siscaro et al., 1999; Stathas, 2000; Erler and Tunç, 2001; Abd-Rabou and El Naggar, 2004). In Spain, the indigenous C. bipustulatus was considered abundant on armored scale insects along the Mediterranean coast (Murcia and Valencia regions) during the beginning of the past century (Mercet, 1911). Other species of this genus that have been described as predators of CRS are C. orbis Casey and C. cacti (L.), both found in coastal California (Forster and Luck, 1996), C. circundatus (G.) a native Australian species that helps parasitoids to reduce the CRS level (Smith et al., 1997), C. nigritus (F.) which was accidentally introduced in South Africa, where it is considered a valuable predator of CRS (Samways, 1985; Bedford, 1998), and the South African indigenous $C$. distigma Klug a widespread and efficient predator even at a relatively low host population density (Bedford, 1998). Several species of Chilocorus have been reared in large numbers for the use against armored scale insects, the more commonly used is C. bipustulatus which can produce more than 600 eggs per female during its lifetime (Kaufmann, 1977; Samways, 1984). Both adults and larvae of Chilocorus spp. possess strong mandibles that allow them to feed on all stages of CRS, including mature females (Forster and Luck, 1996). 

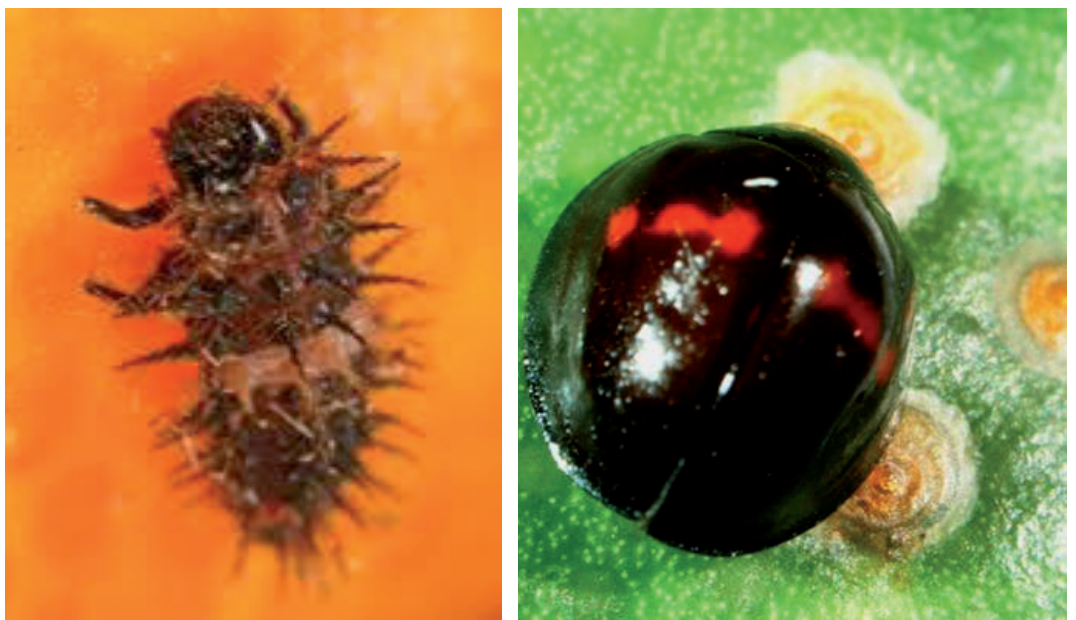

Fig. 1. 21. Larva (left) and adult (right) of $C$. bispustulatus searching for prey on a CRS colony.

Coccidophilus citricola Brethes has been described as a very active armored scale predator in several citrus areas of South America (Crouzel et al., 1973; Ricci, 1986; Adaime da Silva, 2003). Scymnus sp., a very polyphagous genus of predators, was collected on A. aurantii in Turkey and the species Scymnus syriacus Muls. was one of the dominant predators of armored scale insects in various bioclimatic regions of Egypt (Abd-Rabou and El Naggar, 2004; Yarpuzlu et al., 2008).

Cybocephalus spp. was introduced in the United States from China in 1932 but poor success was achieved against CRS (Rosen and DeBach, 1978). The species Cybocephalus politus (Gyllenhal) was common in citrus orchards of Cyprus wherever red scale populations are sufficiently high (Wood, 1963). Cybocephalus rufifrons Reitter both larvae and adults were observed to prey the red scale on branches of citrus in Sicily (Siscaro et al., 1999). Another species, Cybocephalus fodori Endrody-Younga was found as one of the most common predators of armored scale insects in Turkey, Greece and Serbia (Erler and Tunç, 2001; Stathas, 2001; Graora, 2009). 


\subsubsection{Other genera of predators}

Other genera of predators commonly described on CRS belong to the order Neuroptera, families Chrysopidae and Coniopterygidae, Diptera, family Cecidomyiidae, and mites of several order and genera, mostly Hemisarcoptes Meyer (Astigmata: Hemisarcoptidae) (DeBach, 1969; Catling, 1971; Forster and Luck, 1996; Erler and Tunç, 2001; Urbaneja et al. 2005, Yarpuzlu et al., 2008 etc.).

The larvae of Chrysoperla spp. (Stephens), green lacewings, are generalist predators that have been described to feed on young instar scales in Swaziland, California and Australia (Catling, 1971; Furness et al., 1983; Forster and Luck, 1996). The species C. carnea Steph. has been described as predator of CRS in citrus areas of Egypt and Turkey (Abd-Rabou and El Naggar, 2004; Yarpuzlu et al., 2008). Chrysoperla larvae (Fig. 1.22) have been found to feed also on young female stages of the red scale in Spain (Pina 2006).

Conwentzia spp. larvae were determined as predators of A. aurantii in Turkey (Yarpuzlu et al., 2008). In Palestine, Conwentzia psociformis (Curtis) was described as predator of the red scale (Bodenheimer, 1934). Similarly, in citrus areas of eastern Spain, C. psociformis and Semidalis aleyrodiformis (Stephens) were the most common predators (Bru and Garcia-Marí, 2008).
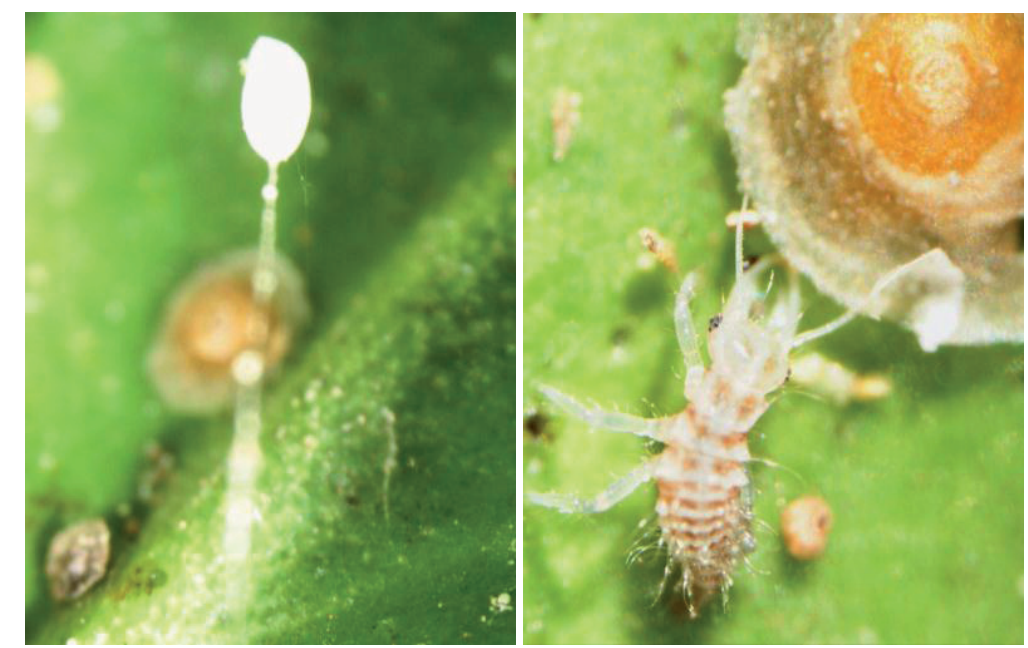

Fig. 1.22. Egg of Chrysoperla spp. in the middle of a CRS colony (left) and larva of C. carnea with a female scale (right). 
The most important Cecidomyiidae species preying on CRS is Lestodiplosis aonidiellae Harris (Fig. 1.23) which was first time documented under the scale cover of A. aurantii in South Africa (Harris, 1968). Later on, larvae of this species have been found feeding on CRS in Morocco and Italy (Panis, 1975; Siscaro et al., 1999). The same species has been described on other armored scales in Uganda and Tanzania (Greathead, 1970). It has been considered one of the main predators of $A$. aurantii in the Mediterranean citrus areas of Spain (Sorribas et al., 2008).
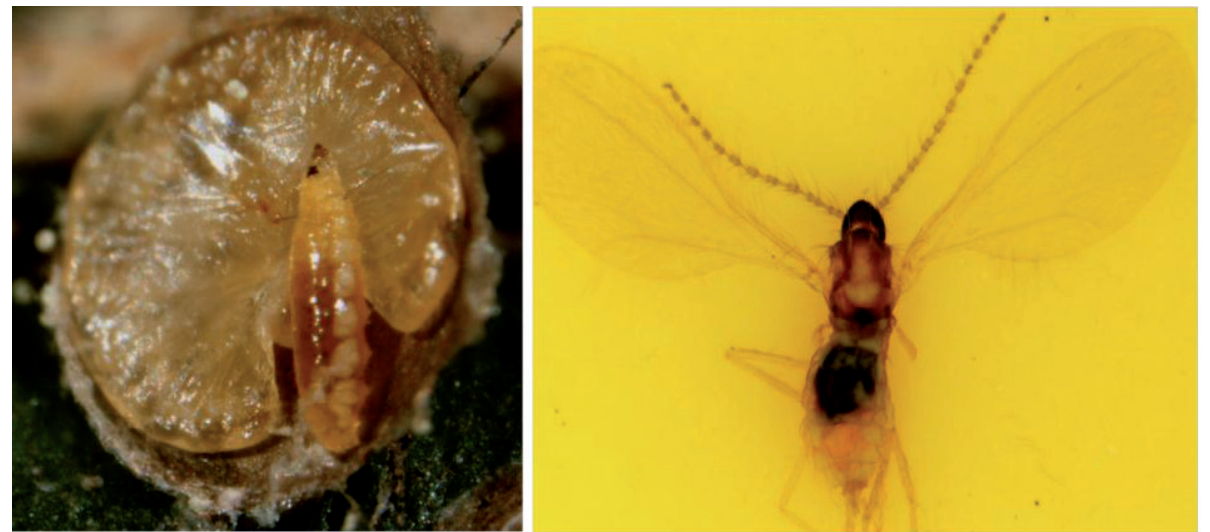

Fig. 1.23. Larva of Lestodiplosis aonidiellae found preying a female CRS (left) and adult captured on a yellow sticky trap (right).

A high number of mite species belonging to different genera have been described as occasional predators of CRS, mainly crawlers (Meyer, 1962; Samways, 1985; Gerson et al., 1990; Luck et al., 1999; Juan-Blasco et al., 2008). The most commonly cited belong to the genus Hemisarcoptes (Fig. 1.24); obligate parasitic mites of armored scale insects (Gerson et al., 1990). Several Hemisarcoptes species have been successfully used as classical biological control agents against armored scale pests. The introduction of $H$. coccophagus Meyer into New Zealand suppressed lantania scale, Hemiberlesia lataniae Signoret (Hill et al., 1993). Similarly H. malus (Shimer) is credited with suppressing oystershell scale, Lepidosaphes ulmi (L.) in apple orchards of Canada and USA (Houck and O'Connor, 1996). Hemisarcoptes coccophagus, H. malus and H. cooremani Thomas are the most important species on CRS (Rosen, 1967; Crouzel et al., 1973; Gerson et al., 1990; Luck et al., 1999; Uygun, 2003). Mass releases of Hemisarcoptes spp. on phoretical deutonymphal stage attached to the elytra of Chilocorus spp. have been performed against armored scale pests to improve its dispersal and to combine the 
effect of both predators (Gerson and Schneider, 1981; Houck and O'Connor, 1991; Charles et al., 1995).
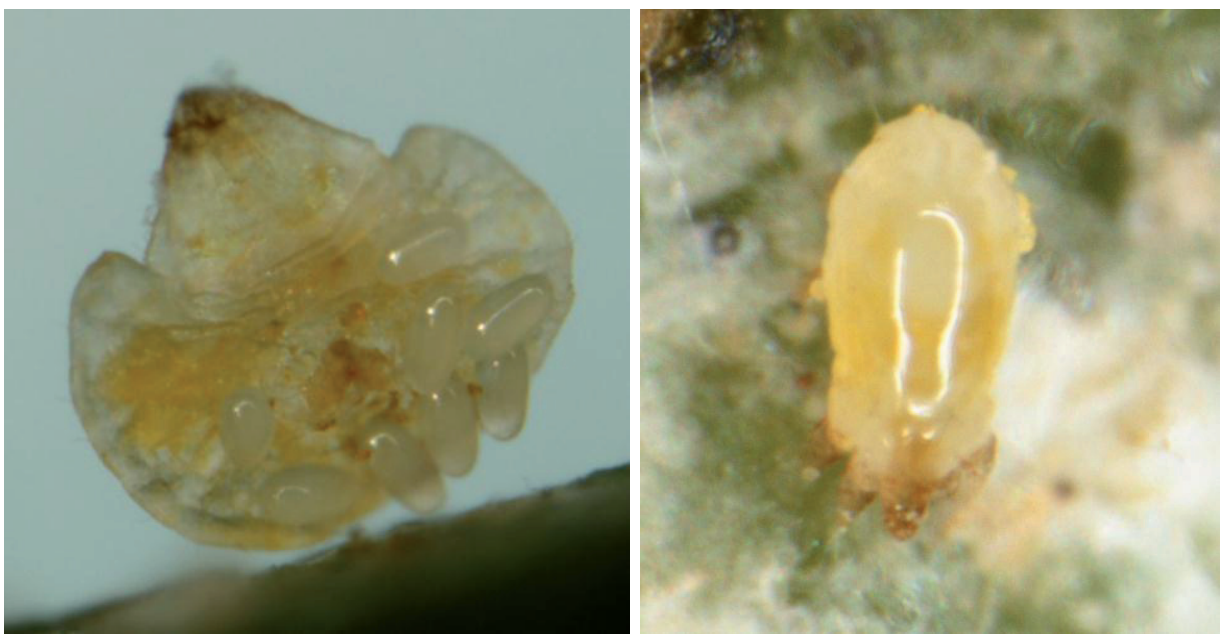

Fig. 1.24. Eggs of Hemisarcoptes sp. deposited below a young a female CRS (left) and adult of Hemisarcoptes sp. found preying on a CRS colony (right).

\subsubsection{Natural enemies of CRS parasitoids.}

Several ant species have been described to disturb or kill CRS parasitoids when they patrol the citrus trees. The most commonly cited are the Argentine ant, Linepithema humile (Mayr), the gray ant, Formica aerata (Francoeur), Lasius grandis (Forel) and Pheidole pallidula (Nylander) (Heimpel et al. 1997, James et al. 1997, Martinez-Ferrer et al., 2002, Pekas et al. 2010a). The effect of ants, mainly the Argentine ant, can be so decisive that in citrus areas like southern California, where biological control is excellent, A. aurantii becomes a pest when ants disrupt parasitoid biological control (Moreno et al., 1987; DeBach and Rosen, 1991).

Spiders of the families Salticidae and Thomisidae were observed to capture adult Aphytis (Heimpel et al., 1997). Similarly, several species of mites, like Pyemotes herfsi Oudemans have been found to prey on different Aphytis species 
(Traboulsi, 1968). Also, the nymphs of a Hemiptera, the assassin bug, Zelus renardii (Kolenati), were observed while capturing adult parasitoids (Heimpel et al., 1997).

It is known that some Coccinellidae predators of CRS, like $R$. lophantae, can feed on parasitoids they find below the scale cover when looking for the body of the scale (Taylor, 1935; Rubtsov, 1952). Similarly, larvae of Cecidomyiidae predators like $L$. aonidiellae can act as predators of parasitoids larvae and pupae they find under the scale cover (personal observation) (Fig. 1.25).
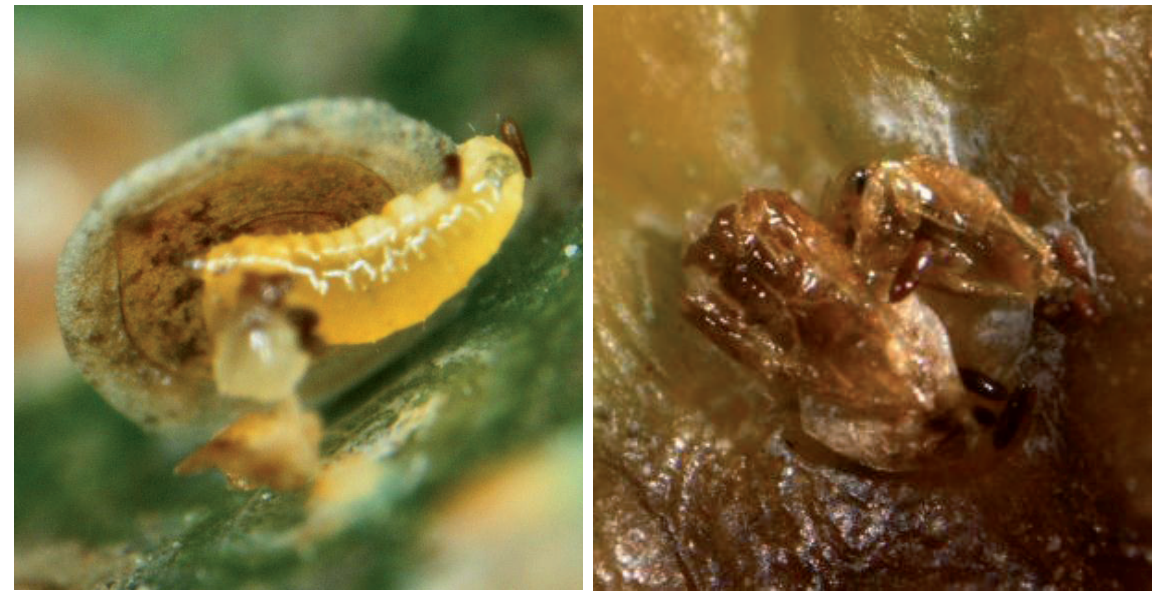

Fig. 1.25. Larva of Lestodiplosis aonidiellae preying on a prepupa of Aphytis (left) and adult of Aphytis whose head has been preyed by Rhyzobius lophantae (right).

Several hyperparasitoid or secondary parasitoid species have been recorded parasitizing Aphytis, Comperiella or Encarsia. Hyperparasitoid species develop as parasitoids on larval and pupal stages of primary parasitoids. In all cases the proportion of hyperparasitoids is very reduced (Traboulsi, 1968). Marietta javensis (Howard) (=Marietta exitosa Compere) is a common hyperparasitoid of $C$. bifasciata in South Africa (Atkinson, 1983; Samways, 1986). The same species has been obtained from Aphytis spp. parasitizing A. aurantii (Rosen, 1965). Another species, M. carnesi (Howard) (Fig. 1.26) attacks Aphytis, Comperiella and Encarsia on many different armored scale insects (Viggiani, 1990). For instance it has been collected from San José scales parasitized by E. perniciosi (Masoodi et al., 1989; McClain et al., 1990). Also, several species of Azotus Howard, like A. perspeciosus and A. pinifoliae have been reported as hyperparasitoids of Aphytis species (Mercet, 1922; Benassy, 1958). 


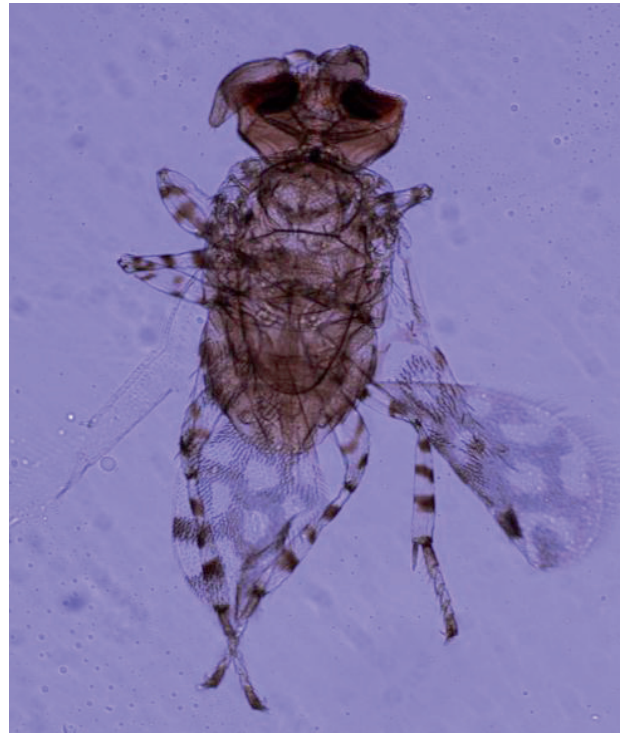

Fig. 1. 26. Adult of Marietta carnesi captured in a pheromone sticky trap.

\subsection{Literature cited}

Abdelrahman, I. 1974. Growth, development and innate capacity for increase in Aphytis chrysomphali Mercet and A. melinus DeBach, parasites of California red scale, Aonidiella aurantii (Mask.). Australian Journal of Zoology, 22: 213- 230.

Abdelrahman, I. 1974b. Studies in ovipositional behaviour and control of sex in Aphytis melinus DeBach, a parasite of California red scale, Aonidiella aurantii (Mask.). Australian Journal of Zoology, 22: 231-247.

Abd-Rabou, S. and El Naggar, M. 2004. Predators of armored scale insects in Egypt. Proceedings of the X International Symposium on Scale Insect Studies, 1: 267.

Adaime da Silva, R., Guerreiro, J. C., Michelotto, M. D. and Busoli, A. C. 2003. Desenvolvimento e comportamento de predaçao de Coccidophilus citricola Bréthes, 
1905 (Coleoptera: Coccinellidae) sobre Aspidiotus nerri Bouché, 1833 (Hemiptera: Diaspididae). Boletín de Sanidad Vegetal-Plagas, 29: 9-15.

Annecke, D. P. and Moran, V. C. 1982. Insects and Mites of cultivated plants in South Africa. Butterworth and Co., South Africa.

Asplanato, G. and Garcia-Marí, F. 2001. Ciclo Estacional de la cochinilla roja californiana Aonidiella aurantii (Maskell) (Homoptera: Diaspidae) en naranjos del sur de Uruguay. Agrociencia, 5: 54-67.

Asplanato, G. and Garcia-Marí, F. 2002. Parasitismo de la cochinilla roja californiana Aonidiella aurantii (Homoptera: Diaspididae) en la zona citrícola de Uruguay. Boletín de Sanidad Vegetal-Plagas, 28: 5-20.

Atkinson, P.R. 1983. Estimates of natural mortality related to environmental factors in a population of citrus red scale, Aonidiella aurantii (Maskell) (Hemiptera: Diaspididae). Bulletin of Entomological Research, 73: 239-258.

Avidov, Z., Balshin, M. and Gerson, U. 1970. Studies on Aphytis coheni, a parasite of the California red scale, Aonidiella aurantii, in Israel. Entomophaga, 15: 191-210.

Baker, J. L. 1976. Determinants of host selection for species of Aphytis (Hymenoptera: Aphelinidae), parasites of diaspine scales. Hilgardia, 44: 1-25.

Beardsley, J. W. and González, R. H. 1975. The biology and ecology of armored scales. Annual Review of Entomology, 20: 49-73.

Bedford, E. C. G. 1996. Problems which we face bringing red scale, Aonidiella aurantii (Maskell), under biological control in citrus in South Africa. Proceedings of the International Society of Citriculture, 1: 485-492.

Bedford, E.C.G., 1998. Red scale Aonidiella auranii (Maskell). In: Bedford, E.C.G., Van den Berg, M.A. and De Villiers, E.A. (eds), Citrus pests in the Republic of South Africa. Dynamic Ad., Nelspruit, South Africa: 132-144.

Bedford, E. C. G. and Grobler, J. H. 1981. The current status of the biological control of red scale, Aonidiella aurantii (Mask.), on citrus in South Africa. Proceedings of the International Citrus Congress. International Society of Citriculture, Tokyo, Japan. 
Bedford, E. C. G. and Cilliers, C. J. 1994. The role of Aphytis in the biological control of armored scale insects on citrus in South Africa. In: Rosen D. (ed) Advances in the study of Aphytis. Intercept Limited, Andover, UK.

Benassy, C. 1958. Influence de l'hôte dans la croissance endoparasataire de quelques Hymenoptères Chalcidiens, parasites de Cochenilles Diaspines. Comptes Rendus de l'Académie des Sciences, Paris, 246: 179-81.

Benassy, C. and Bianchi, H. 1974. Observations sur Aonidiella aurantii Mask. Et son parasite indigene Comperiella bifasciata How. (Hymenoptera. Encyrtidae). OILB/WPRS Bulletin, 3: 39-50.

Ben-Dov, Y. and Rosen, D. 1969. Efficacy of natural enemies of the California red scale on citrus in Israel. Journal of Economical Entomology, 62: 1057-1060.

Ben-Dov, Y. 1990. Taxonomic characters on armored scale insects. In: Rosen, D. (ed) Armored scale insects, their biology, natural enemies and control. Vol. 4A. Elsevier, Amsterdam, the Netherlands.

Blumberg, D. 1997. Parasitoid encapsulation as a defense mechanism in the Coccoidea (Homoptera) and its importance in biological control. Biological control, 8: 225-236.

Blumberg, D. and Luck, R. F. 1990. Differences in the ratio of superparasitism between two strains of Comperiella bifasciata (Howard) (Hymenoptera: Encyrtidae) parasitizing California Red Scale (Homoptera: Diaspidiae) an adaptation to circumvent encapsulation? Annals of the Entomological Society of America, 83: 591- 597.

Bodenheimer, F. S., 1934. Contributions towards the knowledge of the red scale (Chrysomphalus aurantii Mask.) in Palestine. Hadar, 7: 139-148.

Bodenheimer, F. S., 1951. Citrus entomology in the Middle East. Ed. W. Junk. The Hague, The Netherlands.

Borer, E. T., Briggs, C. J., Murdoch, W. W. and Swarbrick, S. L. 2003. Testing intraguild predation theory in a field system: does numerical dominance shift along a gradient of productivity? Ecology Letters, 6: 929-935.

Borer, E. T., Murdoch, W. W. and Swarbrick, S. L. 2004. Parasitoid coexistence: linking spatial field patterns with mechanism. Ecology, 85, 667-678. 
Brewer, R. H. 1971, The influence of the parasite Comperiella bifasciata How., on the populations of two species of armoured scale insects, Aonidiella aurantii (Mask.) and A. citrina (Coq.), in South Australia. Australian Journal of Zoology, 19:53-63

Bru, R. and Garcia-Marí, F. 2008. Seasonal and spatial population trend of predatory insects in eastern-Spain citrus orchards. OILB/WPRS Bulletin, 38: 261-266.

Burger, H. C. and Ulenberg, S. A. 1990. Quarantine problems and procedures. In: Rosen, D. (ed) Armoured scale insects, their biology, natural enemies and control. Vol. $4 B$. World Crop Pests. Elsevier, Amsterdam, the Netherlands.

Cardoso, A. and Gomes, M. L. 1984. Dois coccinelideos predatores pouco conhecidos em Portugal. Boletim da Sociedade Portuguesa de Entomología, 45: 161-167

Cardwell, E. E. and Reagan, C. A. 1999. California red scale insecticide efficacy trial, 1997. Artropod management test, 24: 91.

Carroll, D. P. and Luck, R. F. 1984. Bionomics of California red scale, Aonidiella aurantii (Maskell) (Homoptera: Diaspididae), on orange fruits, leaves, and wood in California's San Joaquin Valley. Environmental Entomology, 13: 847- 853.

Catling H. D., 1971. Studies on the citrus red scale, Aonidiella aurantii (Mask.), and its biological control in Swaziland. Journal of the Entomological Society of South Africa, 34: 393-411.

Charles, J. G. Hill, M.G. and Allan, D.J. 1995. Releases and recoveries of Chilocorus spp. (Coleoptera: Coccinellidae) and Hemisarcoptes spp. (Acari: Hemisarcoptidae) in kiwifruit orchards: 1987-93. New Zealand journal of zoology, 22: 319-324.

Charnov, E. L., Los-den Hartogh, R. L., Jones, W. T. and van den Assem, J. 1981. Sex ratio evolution in a variable environment. Nature, 289: 657-665.

Claps, L. E., Wolff, V. R. S. and González, R. H. 2001. Catálogo de las Diaspididae (Hemiptera: Coccoidea) exóticas de la Argentina, Brasil y Chile. Revista de la Socieded Entomológica Argentina, 60: 9-34.

Collier, T. R., Murdoch, W. W. and Nisbet, R. M. 1994. Egg load and the decision to hostfeed in the parasitoid, Aphytis melinus. Journal of Animal Ecology, 63: 299-306. 
Collins, P. J., Lambkin, T. M. and Bodnaruk, K. P. 2007. Suspected resistance to methidathion in Aonidiella aurantii (Maskell) (Hemiptera: Diaspididae) from Queensland. Australian Journal of Entomology, 33: 325-326.

Compere, H. 1961. The red scale and its natural enemies. Hilgardia, 31: 173-278.

Crouzel, I. S., Bimbonim, H. G., Zanelli, M. and Botto, E. N. 1973. Lucha biológica contra la cochinilla roja australiana Aonidiella aurantii (Maskell) (Hom. Diaspididae) en cítricos. Revista de Investigaciones Agropecuarias, INTA, Buenos Aires, Rep. Argentina Serie 5, Patología Vegetal, 10: 251-318.

Dahms, E. C. and Smith, D. 1994. The Aphytis fauna of Australia. In: Rosen, D. (ed) Advances in the study of Aphytis. Intercept Limited, Andover, UK.

De Santis, L. and Crouzel, I. S. 1994. Species of Aphytis occurring in the Neotropical region and their role in biological control. In: Rosen, D. (ed) Advances in the study of Aphytis. Intercept Limited, Andover, UK.

DeBach, P. 1948. The establishment of the Chinese race of Comperiella bifasciata on Aonidiella aurantii in southern California. Journal of Economic Entomology, 41: 985

DeBach, P. 1953. The establishment in California of an oriental strain of Prospaltella perniciosi Tower on the California red scale. Journal of Economic Entomology, 46: 1103.

DeBach, P. 1969. Biological control of Diaspine scale insects on citrus in California. Proceedings of the 1st International Citrus Symposium, 2: 801-822.

DeBach, P. and White, E. B. 1960. Commercial mass culture of the California red scale parasite. pp. 1-58. Division of Agricultural Science, University of California, Riverside.

DeBach, P. and Sundby, R. A. 1963. Competitive displacement between ecological homologues. Hilgardia, 34: 105-66.

DeBach, P., Fleschner, C. A. and Dietrick, E. T. 1951. A biological check method for evaluating the effectiveness of entomophagous insects. Journal of Economic Entomology, 44: 763-766. 
DeBach, P., Landi, J. H. and White, E. B. 1955. Biological control of red scale. Citrograph, 40: $254,271-72$.

DeBach, P. and Rosen, D. 1991. Biological control by natural enemies. Cambridge University Press. New York, USA.

Deckle, G. W. 1976. Florida armored scale insects. Arthropods of Florida and neighbouring land areas. Florida Department of Agriculture and Consumer Services, 3: 30.

Delucchi, V. 1965. Notes sur le pou de Californie (Aonidiella aurantii Maskell) au Moroc. Annales de la Societe Entomologique de France, 1: 740-788.

Doutt, R. L. 1959. The biology of parasitic hymenoptera. Annual Review of Entomology, 4: $161-182$

Doutt, R. L. and DeBach, P. 1964. Some biological control concepts and questions. In: DeBach, P. (ed) Biological control of insect pests and weeds. Reinhold Pulblishing Corporation, New York.

Drea, J. J. and Gordon, R. D. 1990. Coccinelidae. In: Rosen, D. (ed) Armored scale insects: Their biology, natural enemies and control, Vol. 4B. Elsevier, Amsterdam, Oxford, New York, Tokyo.

Ebeling, W. 1959. Subtropical fruit pests. University of California, Division of Agricultural Sciences, Berkeley, California.

Eliraz, A. and Rosen, D. 1978. Biological and systematic studies of developmental stages in Aphytis (Hymenoptera: Aphelinidae). Larval criteria in the systematic of Aphytis. Hilgardia, 46: 96-101.

Erler, F. and Tunç, I. 2001. A survey (1992-1996) of natural enemies of Diaspididae species in Antalya, Turkey. Phytoparasitica, 29: 299-305.

Fischer, T. W. 1952. Comparative biologies of some species of Aphytis (Hymenoptera: Chalcidoidea) with particular reference to racial differentiation. PhD. Dissertation, Univ. California.

Flanders, S. E. 1943. Mass production of the California red scale and its parasite Comperiella bifasciata. Journal of Economic Entomology, 36: 233-35. 
Flanders, S. E. 1944. Observations on Comperiella bifasciata, an endoparasite of diaspine coccids. Annals of the Entomological Society of America, 37: 365-71.

Flanders, S. E. 1953. Aphelinid biologies with implications for taxonomy. Annals of the Entomological Society of America, 46: 84-94.

Flanders, S. E. 1971. Multiple parasitism of armored coccids (Homoptera) by hostregulative aphelinids (Hymenoptera); ectoparasites versus endoparasites. The Canadian Entomologist, 103: 857-872.

Flint, M. L. 1991. Integrated pest management for citrus, 2nd edition. Publication 3303. University of California. Division of Agriculture and Natural Resources.

Forster, L., Luck, R. and Grafton-Cardwell, E. 1995. Life stages of California red scale and its parasitoids. University of California, Division of Agriculture and Natural Resources, Publication 21529, Oakland, California, USA.

Forster, L. and Luck, R. 1996. The role of natural enemies of California red scale in an IPM program in California citrus. Proceedings of the International Society of Citriculture, 1: 504-507.

Furness, G. O., Buchanan, G. A. George, R. S. and Richardson, N. L.1983. A history of the biological and integrated control of red scale, Aonidiella aurantii on citrus in the Lower Murray Valley of Australia. Entomophaga, 28: 199-212.

Gerson, U. and Schenider, R. 1981. Laboratory and field studies on the mite Hemisarcoptes coccophagus Meyer (Astigmata: Hemisarcoptidae), a natural enemy of armored scale insects. Acarologia, 22: 199-208.

Gerson, U., O’Connor, B. M. and Houck, A. 1990. Acari. In: Rosen, D. (ed) Armored scale insects. Their biology, natural enemies and control.. Elsevier, Oxford, New York, Tokyo.

Godfray, H. C. J. 1994. Parasitoids: Behavioral and Evolutionary Ecology. Princeton Univ. Press.

Gómez-Vives, S. 1999. Biology of Lindorus lophantae Blaisdell (Coleoptera: Coccinellidae), a candidate biocontrol agent of Phenicococcus marlatti Cockerell (Homoptera: Phoenicococcidae) in the date palm grove of Elche, Spain. Proceedings of the 
regional symposium for applied biological control in Mediterranean countries, 1: $115-120$

Gottlieb, Y., Zchori-Fein, E., Faktor, O. and Rosen, D. 1998. Phylogenetic analysis of parthenogenesis-inducing Wolbachia in the genus Aphytis (Hymenoptera: Aphelinidae). Insect Molecular Biology, 7: 393-396.

Grafton-Cardwell E, Ouyang Y, Striggow R, Vehrs S. 2001. Armored scale insecticide resistance challenges San Joaquin Valley citrus growers. California Agriculture, 55: 20-25.

Graora, D., Spasic, R. and Vucetic, A. 2009. Parasitoids and predators of armored scales in some orchards in Serbia. Pesticidi i Fitomedicina, 24: 295-301.

Greathead, D. J. 1970. White sugar-cane scales (Aulacaspis spp.) (Hemiptera: Diaspididae) in East Africa with notes on their natural enemies. East African Agricultural and Forestry Journal, 36: 70-76.

Grout, T. G., Du Toit, W. J., Hofmeyr, J. H. and Richards, G. I. 1989. California red scale (Homoptera: Diaspididae) phenology on citrus in South Africa. Journal of Economic Entomology, 82: 793-798.

Guirrou, Z., El Kaoutari I., Boumezzough A., Chemseddine M. and Hilal, A. 2003. Contrôle des populations d'Aonidiella aurantii (Maskell) en vergers d'agrumes au Maroc. Fruits, 58: 3-11.

Hafez, M. B. 1988. Population fluctuations on parasites of California Red Scale, Aonidiella aurantii (Mask.) (Hom., Diaspidae) in Alexandria. Journal of Applied Entomology, 106: 183-187.

Harris, K. M. 1968. A systematic revision and biological review of the cecidomyiid predators (Diptera: Cecidomyiidae) on world Coccoidea (Hemiptera-Hoptera). Transactions of the Royal Entomological Society of London, 119: 401-494.

Hayat, M. 1983. The genera of Aphelinidae (Hymenoptera) of the world. Systematic Entomology, 8: 63-102.

Heimpel, G.E. and Rosenheim, J. A. 1995. Dynamic host feeding by the parasitoid Aphytis melinus: the balance between current and future reproduction. Journal of Animal Ecology, 64: 153-167. 
Heimpel, G.E. and Collier, T.R. 1996. The evolution of host-feeding behaviour in insect parasitoids. Biological Review, 71: 373-400.

Heimpel, G. E., Rosenheim, J. A. and Mangel, M. 1997. Predation on adult Aphytis parasitoids in the field. Oecologia, 110: 346-352.

Hernández, P., Rodríguez, J. M. and Garcia-Marí, F. 2002. Umbrales de tratamiento para cóccidos diaspídidos en cítricos. Boletín de Sanidad Vegetal-Plagas, 28: 469-478.

Hill, M. G., Allan, D. J., Henderson, R. C. and Charles, J. C. 1993. Introduction of armored scale predators and establishment of the predatory mite Hemisarcoptes coccophagus (Acari:Hemisarcoptidae) on latania scale, Hemiberlesia latania (Homoptera: Diaspididae) in kiwifruit shelter trees in New Zealand. Bulletin of Entomological Research, 83: 369-76.

Hill, D. S. 2008. Pest of crops in warmer climates and their control. Springer, United Kingdom.

Honda, J. and Luck, R. F. 1995. Scale morphology effects on feeding behaviour and biological control potential of Rhyzobius lophanthae (Coleoptera: Coccinelidae). Annals of the entomological society of America, 88: 441-450.

Houck, M. A. and O’Connor, B. M. 1996. Temperature and host effects on key morphological characters of Hemisarcoptes cooremani and Hemisarcoptes malus (Acari: Hemisarcoptidae). Experimental \& Applied Acarology, 20: 667-682.

Houck, M. A. and O'Connor, B. M. 1991. Ecological and evolutionary significance of phoresy on the Astigmata. Annual review of entomology, 36: 611-636.

Huffaker, C. B. and Messenger, P. S. 1964. The concept and significance of biological control. In: DeBach, P. (ed) Biological control of insect pests and weeds. Chapman \& Hall Publ. London.

Huffaker, C. B., Messenger, P. S. and DeBach, P. 1971. The natural enemy component in natural control and the theory of biological control. In: Huffaker, C. B. (ed) Biological control. Plenum Press Publ. New York, London.

James, D. G., Stevens, M. M. and Malley, K. J. O. 1997. The impact of foraging ants on populations of Coccus hesperidum L. (Hem., Coccidae) and Aonidiella aurantii 
(Maskell) (Hem., Diaspididae) in an Australian citrus grove. Journal of Applied Entomology, 121: 257-259.

Jervis. M.A. and Kidd, N.A. 1986. Host-feeding strategies in hymenopteran parasitoids. Biological Reviews, 61: 395 - 434.

Jervis, M. A., Heimpel, G. E., Ferns, P. N., Harvey J. A. and Kidd, N.A. 2001. Life-history strategies in parasitoid wasps: a comparative analysis of 'ovigeny', Journal of Animal Ecology, 70: 442-458

Jiménez-Jiménez, E. and Smith, H.D. 1958. El empleo de enemigos naturales para el control de insectos que constituyen plagas agrícolas en la República Mexicana. Fitófilo, 11: 5 24.

Juan-Blasco, M., Verdú, M. J. and Urbaneja, A. Depredación del piojo rojo de California, Aonidiella aurantii (Maskell), por fitoseidos depredadores. Boletín de Sanidad Vegetal-Plagas, 34: 187-199.

Katundu, J. M. 1988. Integrated control of sugarcane white scale in Tanzania. Taro Newsletter, 3: 15-19.

Kaufmann, T. 1977. Bionomics of Chilocorus bipustulatus and its future for the biological control of the date scale, Parlatoria blanchardi Targ. in Niger, W. Africa. Environmental Entomology, 65: 559-566.

Kehat, M., Swirski, E., Blumberg, D. and Greenberg, S. 1974. Integrated control of date palm pest in Israel. Phytoparasitica, 2: 141-149.

Kennett, C. E. and Hoffmann, R. W. 1985. Seasonal development of the California red scale (Homoptera: Diaspididae) in San Joaquin valley citrus based on degree-day accumulation. Journal of Economical Entomology, 78: 73-79.

Kennett, C. E., McMurtry, J. A. and Beardsley, J. W. 1999. Subtropical and tropical crops. In: Bellows, T. S. and Fisher, T. W. (eds), Handbook of Biological Control: Principles and Applications. Academic Press, San Diego, New York.

Kfir, R. and R. F. Luck. 1979. Effects of constant and variable temperature extremes on sex ratio and progeny production by Aphytis melinus and A. lingnanensis (Hymenoptera: Aphelinidae). Journal of Ecological Entomology, 4: 335-44. 
Lavandero, B., Muñoz, C. and Barros, W. 2006. El talón de Aquiles del control biológico: una nueva visión para su éxito. Agro-Ciencia, 22: 111-123.

Lenteren, J. C. and DeBach, P. 1981. Host discrimination in three ectoparasites (Aphytis coheni, A. lingnanensis and A. melinus) of oleander scale (Aspidiostus nerii). Netherland Journal of Zoology, 31: 504-532.

Lenteren, J. C. 1994. Oviposition behavior of Aphytis (Hymenoptera, Chalcidoidea, Aphelinidae) parasitoids of armored scale insects (Homoptera, Coccoidea, Diaspididae). In: Rosen, D. (ed) Advances of the study of Aphytis. Intercept Ltd, Andover.

Levitin, E. and Cohen, E. 1998. The involvement of acetylcholinesterase in resistance of the California red scale Aonidiella aurantii to organophosphorus pesticides. Entomologia Experimentalis et Applicata, 88: 115-122.

Luck, R., Podoler, H. and Kfir, R. 1982. Host selection and egg allocation behaviour by Aphytis melinus and A. lingnanensis: a comparison of two facultatively gregarious parasitoids. Ecological Entomology, 7: 397-408.

Luck, R. and Podoler, H. 1985. Competitive exclusion of Aphytis lingnanensis by A. melinus: potential role of host size. Ecology, 66: 904-913.

Luck, R. F., 1995. California red scale. In: Nechols, J. R. (ed) Biological Control in the Western United States. Division of Agriculture and Natural Resources, University of California, Oakland, California, USA, Publication No. 3361.

Luck, R. F. 2006. Notes on the Evolution of Citrus Pest Management in California. Proceedings of the California Conference on Biological Control, 5: 1-7.

Martínez, M. A., Soto A. and Garcia-Marí F. 2005. Prospección de la eficacia de clorpirifos en poblaciones del cóccido Aonidiella aurantii (Homoptera: Diaspididae) en parcelas de cítricos de la Comunidad Valenciana. Levante agrícola, 375: 176-182.

Martínez-Ferrer, M. T., Grafton-Cardwell, E. E. and Shorey, H. H. 2003. Disruption of parasitism of the California red scale (Homoptera: Diaspididae) by three ant species (Hymenoptera: Formicidae). Biological Control, 26: 279-286. 
Masoodi, M. A., Trali, A. R., Bhat, A. M., Tiku, R. K. and Nehru, R. K. 1989. Establishment of Encarsia(=Prospaltella) perniciosi, a specific parasite of San Jose scale, on apple in Kashmir. BioControl, 34: 39-43.

McClain D. C., Rock, G. C. and Woolley, J. B. 1990. Influence of trap color and San Jose Scale (Homoptera: Diaspididae) pheromone on sticky trap catches of 10 Aphelinid parasitoids (Hymenoptera). Environmental Entomology, 19: 926-931.

McLaren, I. W. and Buchanan, G. A. 1973. Parasitism by Aphytis chrysomphali Mercet and A. melinus DeBach of California red scale, Aonidiella aurantii (Mask.), in relation to seasonal availability of suitable stages of the scale. Australian Journal of Zoology, 21: 111-117.

Mercet, R. G. 1911. Las plagas del naranjo en Valencia. Proceedings of the Asociación Española para el Progreso de las Ciencias Congress, 4:1-17.

Mercet, R. G. 1912. Un parásito del “poll-roig”. Boletín de la Real Sociedad Española de Historia Natural, 12: 135-140.

Mercet, R.G. 1922. El género Azotus Howard. Boletin de la Real Sociedad Española de Historia Natural, 22:196-200

Meyer, M. K. P. 1962. Two new mite predators of red scale (Aonidiella aurantii) in South Africa. South African Journal of Agriculture Science, 5: 411-418.

Moreno, D. S., Haney, P. B. and Luck, R. F. 1987. Control of the Argentine ant, Iridomyrmex humilis (Hymenoptera: Formicidae), with chlorpyrifos and diazinon and subsequent effects on populations of several citrus pests. Journal of Economic Entomology, 80: 208-214.

Murdoch, W. W., Luck, R. F., Walde, S., Reeve, J. D. and Dicky, S. Y. 1989. A refugee for red scale: the role of size-selectivity by a parasitoid wasp. Ecology, 70: 1700-1706.

Murdoch, W.W., Luck, R. F., Swarbrick, S. L., Walde, S. and Yu, D. S. 1995. Regulation of an insect population under biological control. Ecology, 76: 206-217.

Murdoch, W.W., Briggs, C. J. and Nisbet, R. M. 1996. Competitive displacement and biological control in parasitoids: a model. The American Naturalist, 184: 807-826. 
Murdoch, W. W., Briggs, C. J. and Swarbrick, S. L. 2005. Host suppression and stability in a parasitoid-host system: experimental demonstration. Science, 309: 610-613.

Murray, D. A. H. 1976. Insect pests of passion fruit. Queensland Agricultural Journal, 102:145-151.

Myartseva, S. N., Ruíz-Cancino, E. and Coronado-Blanco, J. M. 2010. El género Aphytis Howard (Hymenoptera: Chalcidoidea. Aphelinidae) en México, clave de especies y descripción de una especie nueva. Dugesiana, 17: 81-94.

Myartseva, S. N. 2001. A new species of parasitoid wasp of genus Encarsia (Hymenoptera: Aphelinidae) from Tamaulipas, Mexico. Acta Zoologica Mexicana, 82: 13-18.

Nell, R. G. 1933. A comparison of Aonidiella aurantii and Aonidiella citrina, including a study of the internal anatomy of the latter. Hilgardia, 7: 417-466.

Opp, S. B. and Luck, R. F. 1986. Effects of host size on selected fitness components of Aphytis melinus and A. lingnanensis (Hymenoptera: Aphelinidae). Annals of the Entomological Society of America, 79: 700-704.

Orphanides, G. M. 1984. Competitive displacement between Aphytis spp. (Hym.: Aphelinidae) parasites of the California red scale in Cyprus. Entomophaga, 29: 275281.

Panis, A. 1975. Une pulvinaire de la cane a sucre d'introduction récente au Maroc (Homoptera, Coccoidea, Coccidea). Revue Zool. Agric. et Path. Veg., 74: 147-153.

Papacek, D. 2009. Integrated pest management experiences in citrus: Trends and solutions. Second conference on pheromones, food lure, traps and biological control: Alternatives for the $21^{\text {st }}$ century. Murcia, Spain.

Parry-Jones, E., 1936. Bionomics and ecology of red scale in Southern Rhodesia. Publication Mazoe Citrus Experimental Station Annual Report, 5: 11-52.

Pekas, A., Tena, A., Aguilar, A. and Garcia-Marí, F. 2010a. Effect of Mediterranean ants (Hymenoptera: Formicidae) on California red scale (Hemiptera: Diaspididae) populations in citrus orchards. Environmental Entomology, 39: 827- 834.

Pekas, A., Tena, A., Aguilar, A. and Garcia-Marí, F. 2010b. Influence of host size on parasitism by Aphytis chrysomphali and A. melinus (Hymenoptera: Aphelinidae) in 
Mediterranean populations of California red scale Aonidiella aurantii (Hemiptera: Diaspididae). Biological Control, 55: 132-140.

Pelekassis, C. D. 1974. Historical review of biological control of citrus scale insects in Greece. OILB/WPRS Bulletin, 3: 14-20.

Pina, T. 2006. Control biológico del piojo rojo de California, Aonidiella aurantii (Maskell) (Hemiptera: Diaspididae) y estrategias reproductivas de su principal enemigo natural Aphytis chrysomphali Mercet (Hymenoptera: Aphelinididae). Doctoral Thesis, Universitat de Valencia, Spain.

Pina, T. and Verdú, M. J. 2007. El piojo rojo de California, Aonidiella aurantii (Maskell), y sus parasitoides en cítricos de la Comunidad Valenciana. Boletín Sanidad Vegetal Plagas, 33: 357-368.

Polaszek, A., Abd-Rabou and Huang, J. 1999. The egyptian species of Encarsia (Hymenotpera: Aphelinidae): a preliminary review. Zoologische Medelingen Leiden, 73: $131-163$.

Quayle, H. J. 1941. Insects of citrus and other subtropical fruits. Comstock Publishing Co., Ithaca, New York.

Quickie, D. L. J. 1997. Parasitic Wasps. Chapman and Hall, New York, USA.

Ricci, J. G. 1983. Descripción de los estados preimaginales de Lindorus lophantae Blaisd. (Col. Coccinelidae), predador de cochinillas (Homoptera) en cítricos de Tucumán (Argentina). CIRPON, Revista de Investigación, 1: 1-14.

Ricci, J. G. 1986. Breve descripción, hábitos de alimentación y enemigos naturales de tres coccinélidos predadores de diaspídidos en cítricos de Tucumán (Argentina). CIRPON, Revista de Investigación, 4: 7-25.

Richardson, N. L. 1978. Biological aspects of co-existence between Comperiella bifasciata Howard (Hymenoptera: Chalcidoidea: Encyrtidae) and Aphytis spp. Howard (Hymenoptera: Chalcidoidea: Aphelinidae). Proceedings of the International Society of Citriculture, 1: 150-153.

Rodrigo, E., Troncho, P. and Garcia-Marí, F. 1996. Parasitoids (Hym.: Aphelinidae) of three scale insects (Hom.: Diaspididae) in a citrus grove in Valencia, Spain. Entomophaga, 41: 77-94. 
Rosen, D. 1965. The Hymenopterous parasites of citrus armored scales in Israel (Hym., Chalcidoidea). Annals of the Entomological Society of America, 58: 388-396.

Rosen, D. 1967. Biological and integrated control of citrus pests in Israel. Journal of Economic Entomolgy, 60: 1422-27.

Rosen, D. 1990. Armored scale insects. Their biology, natural enemies and control. Vol. A. Elsevier. Amsterdam, Oxford, New York, Tokyo.

Rosen, D. and P. DeBach. 1978. Diaspididae. In: Clausen, C. P. (ed) Introduced Parasites and Predators of Arthropod Pests and Weeds. U.S.D.A. Agric. Handbk. No. 480, Washington, D.C.

Rosen, D. and P. DeBach. 1979. Species of Aphytis of the world (Hymenoptera: Aphelinidae), Dr. W. Junk Publishers, The Hague, Boston, London.

Rosen, D. 1994. Fifteen years of Aphytis research - an update. In: Rosen, D. (ed) Advances in the study of Aphytis. Intercept Limited, Andover, UK.

Rosenheim, J. A. and Hongkham, D. 1996. Clutch size in an obligately siblicidal parasitoid wasp. Animal Behaviour, 51: 841-852.

Rubtsov, I. A. 1952. Lindorus, an effective predator or diaspine scales. Russkoe Entomologicheskoe Obozrenie, 32: 96-106.

Samways, M. J. 1984. Biology and economic value of the scale predator, Chilocorus nigritus (F.) (Coccinellidae). Biocontrol News and Information, 5: 91-104.

Samways, M. J. 1985. Relationship between red scale, Aonidiella aurantii (Maskell) (Hemiptera: Diaspididae), and its natural enemies in the upper and lower parts of citrus trees in South Africa. Bulletin of Entomological Research, 75: 379-393.

Samways, M. J. 1986. Spatial and temporal population patterns of Aonidiella aurantii (Maskell) (Hemiptera: Diaspididae) parasitoids (Hymenoptera: Aphelinidae and Encyrtidae) caught on yellow sticky traps in citrus. Bulletin of Entomological Research, 76: 265-274.

Sengonca, C., Uygun, N., Karaca, I. and Schade, M. 1998. Primary studies on the parasitoid fauna of Coccoidea in cultivated and non-cultivated areas in the east Mediterranean region of Turkey. Anz. Schadlingskade, Pflanzenschutz, Umweltschutz, 71: 128-131. 
Siscaro, G., Longo, S. and Lizzio, S. 1999. Ruolo degli entomofagi di Aonidiella aurantii (Maskell) (Hom.: Diaspididae) in agrumeti siciliani. Phytophaga, 9: 41-52.

Siscaro, G., Di Franco, F. and Zappalà, L. 2008. On the presence and diffusion of Comperiella bifasciata How. (Hymenoptera: Encyrtidae) in Southern Italy. IOBC/WPRS Bulletin, 38: 42-45.

Smirnoff, W. 1950. Sur la biologie au Maroc de Rhizobius lophantae Blaisd. (Col. Coccinelidae). Revue de pathologie végétale et d'entomologie agricole de France, 29: 190-194.

Smith, H. S. 1942. A race of Comperiella bifasciata successfully parasitizes California red scale. Journal of Economic Entomology, 35: 809-12.

Smith, D. 1978. Biological control of scale insects on citrus in south-eastern Queensland. Journal of the Australian Entomology Society, 17: 367-371.

Smith, D., Beattie, G. A. C. and Broadley, R. 1997. Citrus pests and their natural enemies: integrated pest management in Australia. Queensland Department of Primary Industries, Brisbane, Australia.

Snowball, G. J. and Sands, D. P. 1971. Natural enemies of diaspid scales of citrus in eastern Australia. CSIRO Division of Entomology Annual Report 1970-71.

Sorribas, J., Rodríguez, R., Rodrigo, E. and Garcia-Marí, F. 2008. Parasitism levels and species of natural enemies in field populations of California red scale Aonidiella aurantii (Hemiptera: Diaspididae) in eastern Spain. IOBC/WPRS Bulletin, 38: 26-33.

Soto, A., Borrás, M., Vercher, R. and García-Marí, F. 2008. Chrysomphalus aonidum (L.) (Hemiptera: Diaspididae) in Spain. Studies on its biology and population dynamics. IOBC/ WPRS Bulletin, 38: 77-81.

Stansly, P. A. 2003. Role of pesticides and weather in the first reported outbreak of California red scale (Homoptera: Diaspididae) on Florida citrus. Proceedings of the Florida State Horticultural Society, 116: 226-230.

Stathas, G. J. 2000. Rhyzobius lophantae prey consumption and fecundity. Phytoparasitica, 28: 203-211. 
Stathas, G. J. 2001. Ecological data on predators of Parlatoria pergandii on sour orange trees in Southern Greece. Phytoparasitica, 29: 207-214.

Stofberg, F. J., 1937. The citrus red scale (Aonidiella aurantii Mask.). Science Bulletin, Department of Agriculture, Union of South Africa, 165: 1-29.

Tashiro, H. and Beavers, J. B. 1968. Growth and development of the California red scale, Aonidiella aurantii. Annals of the Entomological Society of America, 61: 1009-1014.

Taylor, T. H. C. 1935. The campaign against Aspidiotus destructor Sign. in Figi. Bulletin of Entomology Research, 26: 1-100.

Thompson, S. N. 1999. Nutrition and culture of entomophagous insects. Annual Review of Entomology, 44: 561-592.

Traboulsi, R. 1968. Predateurs et parasites d'Aphytis. Entomophaga, 13: 345-355.

Troncho, P., Rodrigo, E. and Garcia-Marí, F. 1992. Observaciones sobre el parasitismo en los diaspinos Aonidiella aurantii (Maskell), Lepidosaphes beckii (Newman) y Parlatoria pergandei (Comstock) en una parcela de naranjo. Boletín de Sanidad Vegetal-Plagas, 18: 11-30.

Tumminelli, R., Conti, F., Saraceno, F., Raciti, E. and Schiliró, R. 1996. Seasonal development of California red scale (Homoptera: Diaspididae) and Aphytis melinus DeBach (Hymenoptera: Aphelinidae) on citus in Eastern Sicily. Proceedings International Society of Citriculture, 1: 642-648.

Urbaneja, A., Ripollés, J. L., Abad, R., Calvo, J., Vanaclocha, P., Tortosa, D., Jacas, J. A. and Castañera, P. 2005. Importancia de los artrópodos depredadores de insectos y ácaros en España. Boletín de Sanidad Vegetal-Plagas, 31: 209-223.

Uygun, N. 2003. Las plagas de los cítricos y su control mediante métodos de CIP en Turquí. Phytoma España, 153: 155-167.

Vehrs, S. L. and Grafton-Cardwell, E. E. 1994. Chlorpyrifos effect on armored scale (Homoptera: Diaspididae) populations in San Joaquin Valley citrus. Journal of Economic Entomology, 87: 1046-1057. 
Viggiani, G. 1987. Le specie italiane del genere Encarsia Foerster (Hymenoptera: Aphelinidae). Bollettino del Laboratario di Entomologia Agraria 'Filippo Silvestri' di Portici, 44: 121-179.

Viggiani, G. 1988. Citrus pest in the Mediterranean basin. Proceedings of the Sixth International Citrus Congress, 3: 1067-1073.

Viggiani, G. 1989. Il controlo integrato della cocciniglia bianca del pesco. L'informatore agrario- Verona, 25: 61-65.

Viggiani, G. 1990. Hyperparasites In: Rosen, D. (ed) Armored scale insects, their biology, natural enemies and control. Vol. 4A. Elsevier, Amsterdam.

Washington, J. R. and Walker, G. P. 1990. Histological studies of California red scale (Homoptera: Diaspididae) feeding on citrus. Annals of the Entomological Society of America, 83: 939-948.

Werren, J. H.; Windsor, D. and Guo, L. R. 1995. Distribution of Wolbachia among neotropical arthropods. Proceedings of the Royal Society of London. Serie B, 262: $197-204$

Willard, J. R. 1973. Wandering time of the crawlers of California red scale, Aonidiella aurantii (Mask.) (Homoptera: Diaspididae), on citrus. Australian Journal of Zoology, 20: $217-229$.

Wood, B. J. 1963. Imported and indigenous natural enemies of citrus coccids and aphids in Cyprus, and an assessment of their potential value in integrated control programmes. Entomophaga, 1: 67-82.

Yarpuzlu, F., Oztemyz, M. and Karacaodlu, M. 2008. Natural enemies and population movement of the California Red Scale, Aonidiella aurantii Maskell (Homoptera: Diaspididae) with efficiency of parasitoid, Aphytis melinus (How.) (Hymenoptera: Aphelinidae) in Lemon Orchards. Journal of Entomology Research Society, 10: 43-58.

Yu, D. S., Luck, R. F. and Murdoch, W. W. 1990. Competition, resource partitioning and coexistence of an endoparasitoid Encarsia perniciosi and an ectoparasitoid Aphytis melinus of the California red scale. Ecological Entomology, 15: 469-480. 
Zchori-Fein, E.; Rosen, D. And Roush, R. T. 1994. Microorganisms associated with thelytoky in Aphytis lingnanensis Compere (Hymenoptera: Aphelinidae). International Journal of Insect Morphology and Embryology, 23: 169-172. 


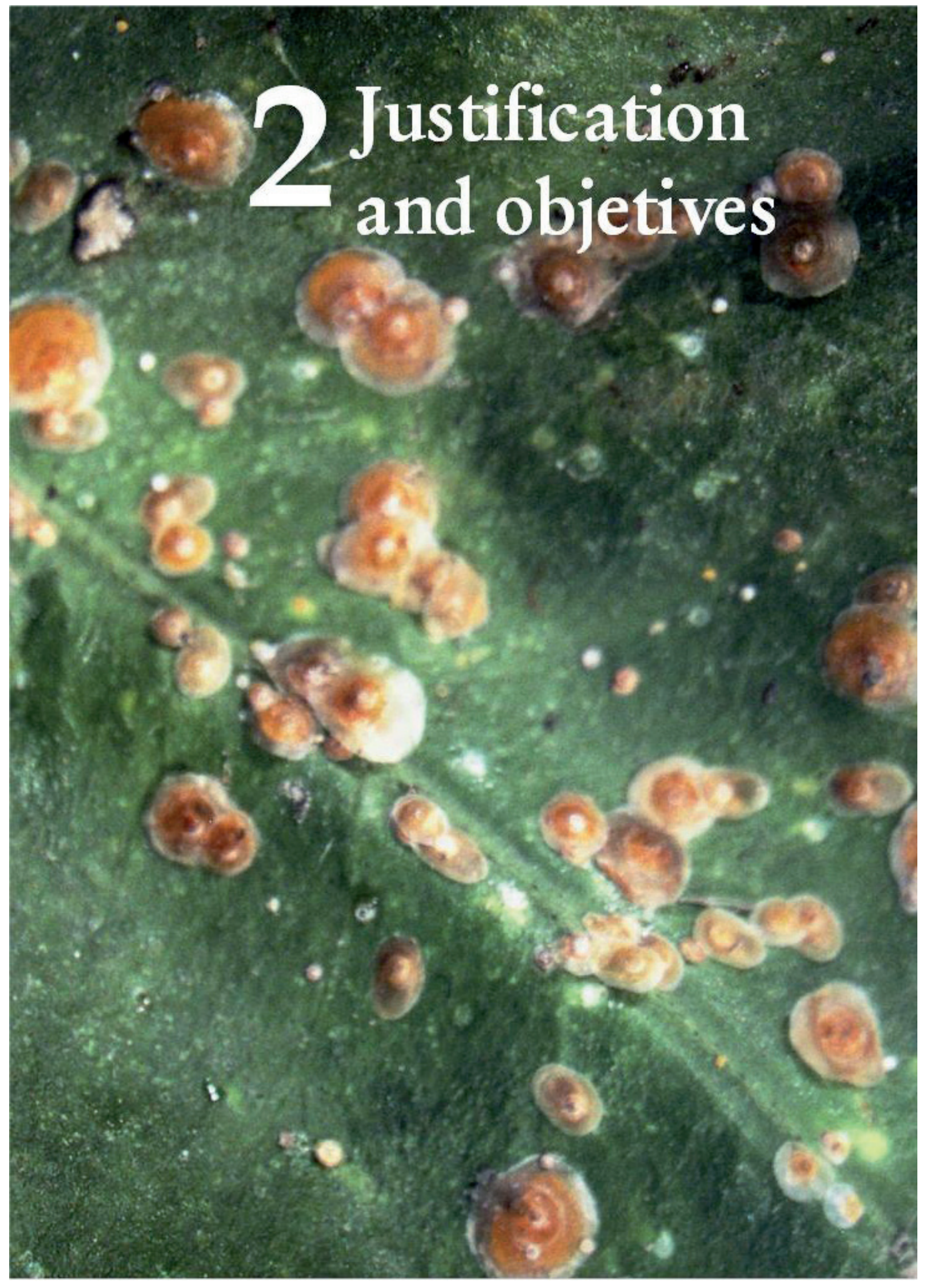



In eastern Spain, like in many citrus areas around the world, the California red scale is considered a key pest of citrus that has spread during the last decades up to cover a vast extension of agricultural landscapes. Chemicals have been traditionally used for its control but year after year its presence has been cited in more citrus areas. Treatments can temporarily control the pest but this is usually followed by a new population outbreak in a short period which obliges to more treatments during the year or the increase of the doses. The biological control of $A$. aurantii, which encourage naturally existing natural enemies or introduce new ones, is probably the more efficient system to reduce the pest to an economic level and the more ecological option. Biological control techniques require knowledge about the natural enemy species composition in the field and their seasonal fluctuation as well as the parasitism and predatory levels in order to decide future actuations like introduction of new species. Parasitoids have demonstrated to be highly efficient and rather specific armored scale controllers. The acquaintance of each parasitoid climate requirements and their resistance to extreme temperature and humidity conditions is essential information in order to decide which species are adequate for each agroclimatic region.

The particular objectives of each article are described below:

1. Parasitoid competitive displacement and coexistence in citrus agroecosystems: linking species distribution with climate

Studies of Paul DeBach demonstrated the competitive displacement between Aphytis species, the main CRS control agents. However little is known about the mechanisms that explain competitive exclusion or coexistence of these parasitoids or the effects of climate under this competition. Similarly, the effect of climate on the fluctuation of the parasitoid species composition along the year has not been previously studied. In eastern Spain, previous studies determined Aphytis melinus and A. chrysomphali as the two main CRS parasitoid species. Less is known about their geographical and seasonal distribution from north to south or about the abundance, climate preferences and seasonal fluctuation of the third parasitoid in importance, Encarsia perniciosi, whose field distribution has not been previously 
documented in Spain. The first paper of this Thesis tries to elucidate these questions as well as to estimate the relative proportion of each species in different geoclimatic areas, identify the presence of other parasitoid species like A. lingnanensis and delimit their geographical spread. On the other hand, in this first paper, we aimed to analyze the validity of two methods, $A$. aurantii pheromone sticky traps and rearing cages with plant material (fruits and branchlets), to evaluate the relative abundance of parasitoids and the sex ratio in biparental species and to compare with CRS males captures.

2. Comparative efficacy of different combinations of natural enemies for the biological control of California red scale in citrus groves

Although parasitoids are considered as the main CRS control agents, the relative importance of predators shouldn't be underestimated. Several papers have dealt with the effect of some CRS natural enemies on the host population; however there are no studies about which combination of natural enemies achieves the best pest control. In the second paper of this Thesis we aimed to estimate the relative incidence of parasitoids and predators on the host and the parasitism rates reached by the three main parasitoid species of eastern Spain. We analyzed the parasitism rates reached along the year by the three existing parasitoid species, A. melinus, $A$. chrysomphali and E. perniciosi to determine the preferred plant substrate (branchlets or fruits) for parasitism or multiparasitism by each species. In addition, we attempted to know which combination of parasitoids reaches higher total parasitism levels. Another objective was to identify the main CRS predator species and its abundance in eastern Spain. Finally, we tried to assess the global mortality of CRS population in field conditions and the mortality due to Aphytis along the year to determine the periods of the year when CRS natural mortality is the highest and the lowest.

3. Effects of climate on the introduction, distribution and biotic potential of parasitoids: Applications in the biological control of California red scale

The introduction of new parasitoid species complementing naturally existent has been practiced during many years but a high proportion of the introduced species 
failed to establish. In addition, there are many documented cases of damages to nontarget organisms by species released for biological control and the rearing and the releasing process can be very expensive. Hence the importance of a deep knowing on the biology and climate requirements of selected species for introduction. The biology and life-history traits of Aphytis species has been widely studied by numerous authors, but this is not the case of the two main CRS endoparasitoids, Comperiella bifasciata and Encarsia perniciosi whose climate responses and lifehistory traits (development time, progeny production, longevity, intrinsic rate of increase) remains partially unknown. In our third paper we tried to know more about the biology of both species in the laboratory under different temperature-humidity combinations and relate this with their field distribution. We also intended to know the differences in parasitoid species composition between inland and coastal citrus areas and between both and subtropical citrus areas. We compared the climate data of each area trying to establish temperature and relative humidity differences which are responsible of the variation in species composition. Climate and field data was related with laboratory results and previous literature about the intrinsic rate of increase $\left(r_{m}\right)$ of Aphytis species with the objective of develop a method to predict the potential areas of establishment and distribution of introduced parasitoids. 



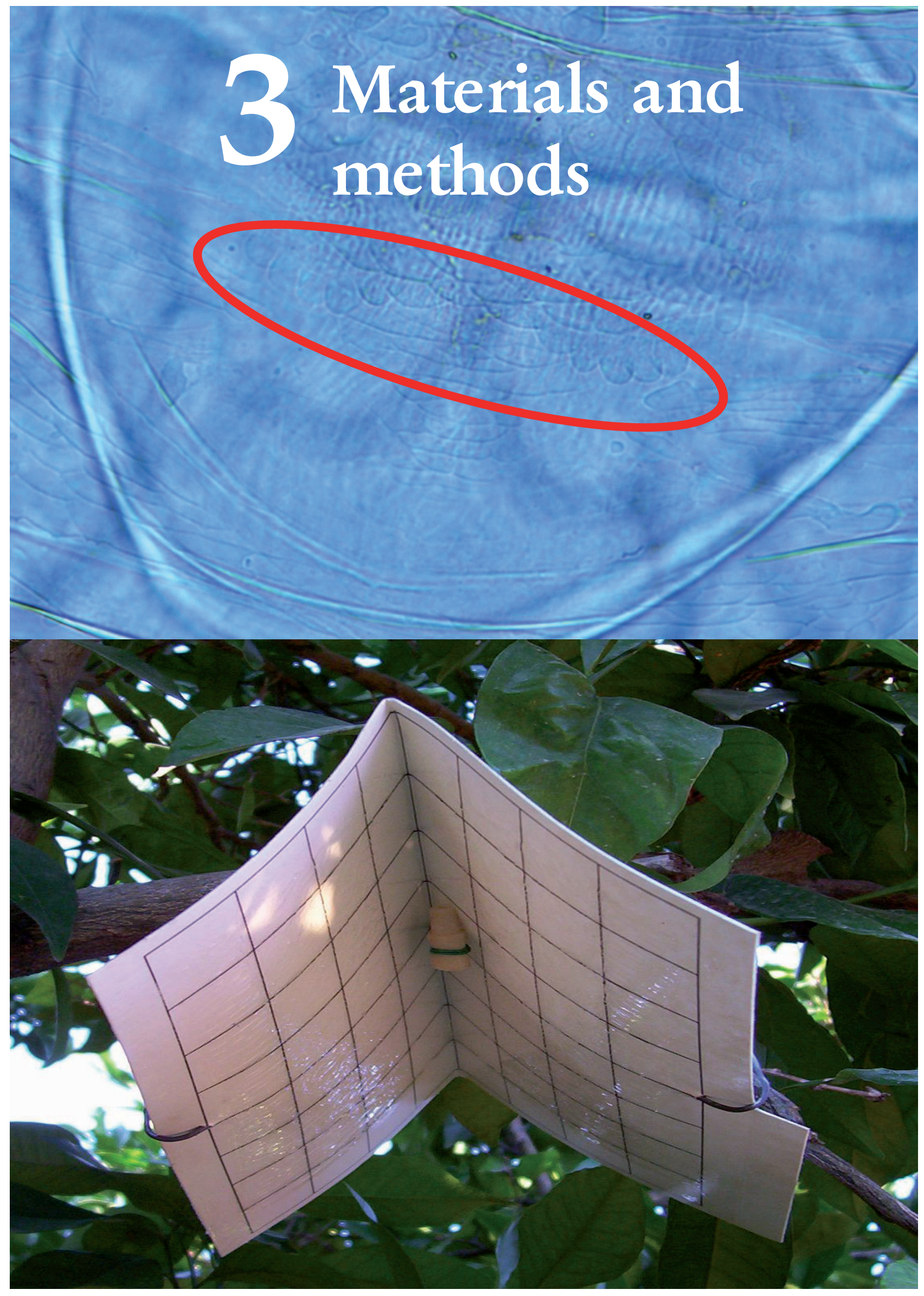



Along the five years of this research we sampled a total of 246 citrus groves belonging to inland, coastal and subtropical citrus areas of Eastern Spain. The landscape of study consists of intensive agriculture composed mainly by small citrus groves of $<1$ ha and spread over an extension of about 200,000 ha in an almost continuous belt, $400 \mathrm{~km}$ long from north to south and $70 \mathrm{~km}$ wide. This is the largest citrus area in Europe and citrus is the most important production in the Spanish Mediterranean agriculture.

The groves were representative of the cultural practices usually applied by local growers, including organic groves, groves managed by IPM practices, and groves under traditional chemical management. The most important citrus species or varieties usually cultivated in Eastern Spain were included.

Two different systems of sampling CRS parasitoids and predators in the field were used: 1) adults captured on A. aurantii pheromone sticky traps or yellow sticky traps placed on citrus trees, and 2) field-collected samples of branchlets and/or fruits highly infested by $A$. aurantii. For the third research of this study field releases and laboratory experiments with the two endoparasitoids C. bifasciata and E. perniciosi were also performed.

Although detailed description of materials and methods is given in the appropriate section of the chapters related with each research, here we expose a brief description of the main materials and methods used for the three parts in which this Thesis is divided.

\subsection{First research}

For the first study we surveyed citrus groves located all along the Mediterranean coast of Spain. Pheromone and chromatic field traps coated with adhesive were collected from 100 commercial citrus groves in full production between June 2005 and May 2006 in order to identify captured parasitoids. These groves belonged to a survey net established by the Agriculture Dep. of the Valencia Region Government (Citrus Phytosanitary Survey Project - Plan de Vigilancia Fitosanitaria de Cítricos) to monitor citrus pest populations all along the Valencia 
citrus area. This net was responsible of the periodical changing of traps and the check of the CRS level and extension. It was used to decide the areas in which sampled groves were located as presence of the pest was confirmed (Fig. 3.1).

Eight different pheromone or chromatic traps were randomly placed in different trees of each grove. The type of traps that showed CRS parasitoid captures were A. aurantii pheromone traps and yellow sticky traps. Pheromone traps consist of a 19 x $19 \mathrm{~cm}$ tent-type white cardboard with a synthetic female pheromone lure attached to the center underside ceiling. Yellow sticky traps were rectangular plastic traps of $15 \times 20 \mathrm{~cm}$ (Fig. 3.2). Every week 50 of the traps were collected and replaced, so that each trap spent 14 days in the field.
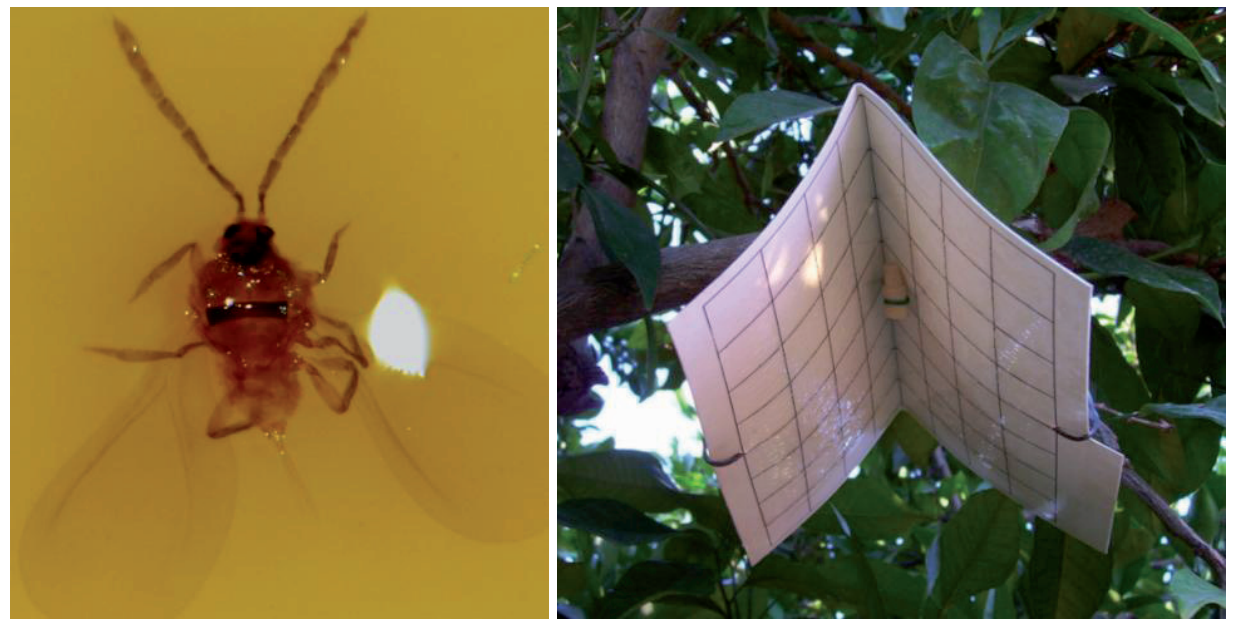

Fig 3.2. Adult male of $A$. aurantii captured in a yellow sticky trap and a pheromone sticky card placed in a citrus tree.

To complement field traps data, during the period November 2004 to March 2008, samples of branchlets (twigs with leaves) and/or fruits infested with $A$. aurantii were randomly collected from 134 citrus groves (20 of them belonging to the previous group) located in the area of study. Both branchlets and fruits were separately kept in rearing cages maintained inside climatic chambers $\left(26-28^{\circ} \mathrm{C}, 60 \%\right.$ relative humidity, 16:8 hr photoperiod) (Fig. 3.3) up to the emergence of adult parasitoids. These parasitoids were collected on yellow sticky traps placed inside the cages or laying dead from the bottom of the cages. Males of CRS and parasitoids captured were identified and counted. 


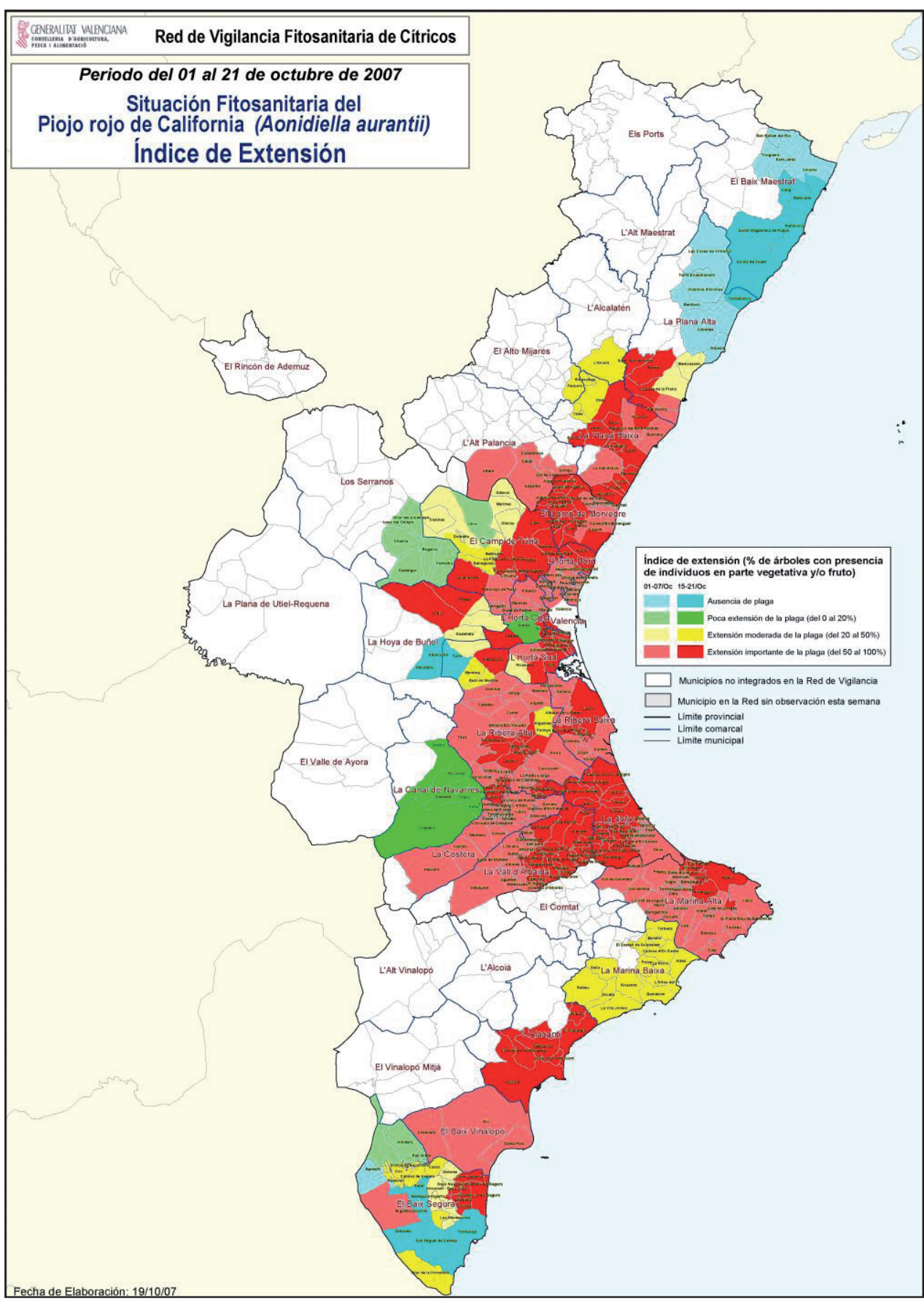

Fig 3.1. Example of the monthly maps of $A$. aurantii distribution and abundance in Eastern Spain generated by the Citrus Phytosanitary Survey Project (red: high level, blue: not present). 
Fig 3.3. Rearing cages containing branchlets and fruits samples inside a climatic chamber.

Due to the high number of Aphytis we had to identify it was necessary to develop a rapid method to reduce the time required for the cleaning and digestion of insects, a previous step for the correct observation of crenulae. Several methods and products were tested to eliminate the glue of the traps and digest the insects (xylene from $1 \mathrm{~h}$. to 48 h., lactic acid, potassium hydroxide solution and Nesbitt

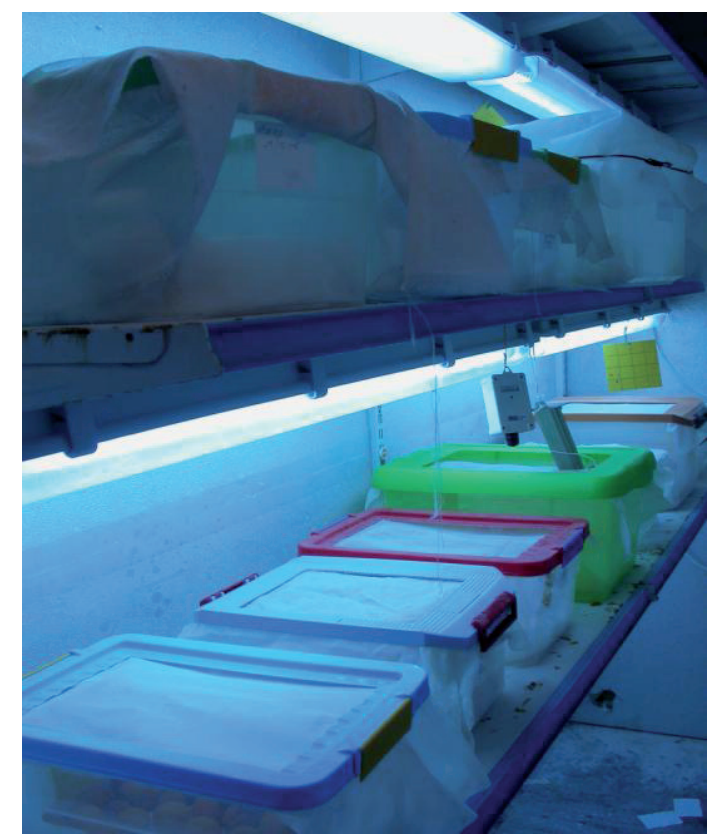
liquid). The option chosen was $20 \mathrm{~h}$. xylene $+30 \mathrm{~min}$. Nesbitt digestion $+1 \mathrm{~min}$. heating under flame which provides fast location and clear observation of insects since they are not completely digested and their red heads are easily identified (the body of Aphytis is digested faster than the head) (Fig. 3.4).

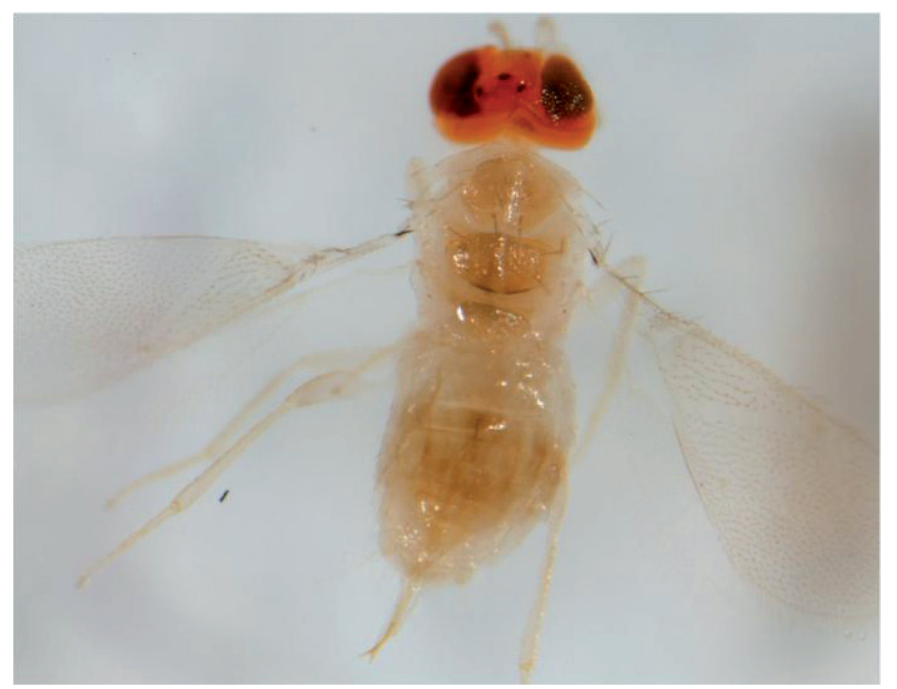

Fig 3.4. Adult of Aphytis digested up to red head using the xylene + Nesbitt + flame heating protocol. 
The same method of digestion was used with the endoparasitoids, mainly for the identification of Encarsia perniciosi, as this parasitoid could be easily misidentified with other species of Encarsia present in the area of study. The species of Encarsia more frequently captured in field traps as they parasitize armored scales of citrus different than CRS were E. brimblecombei, E. citrina and E. inquirenda. The separation of these species from E. perniciosi was based mainly on the antennal formula and form (the clava, the funicle and the pedicel length and width can be used for some of them), the wing (mainly the length of the marginal fringe, the wing disc and the marginal vein) and the relation between the ovipositor size and the mid tibia (Chart 3.1). However, sometimes direct comparative observation under binocular of the abdomen shape and pigmentation was enough for the identification of some species.

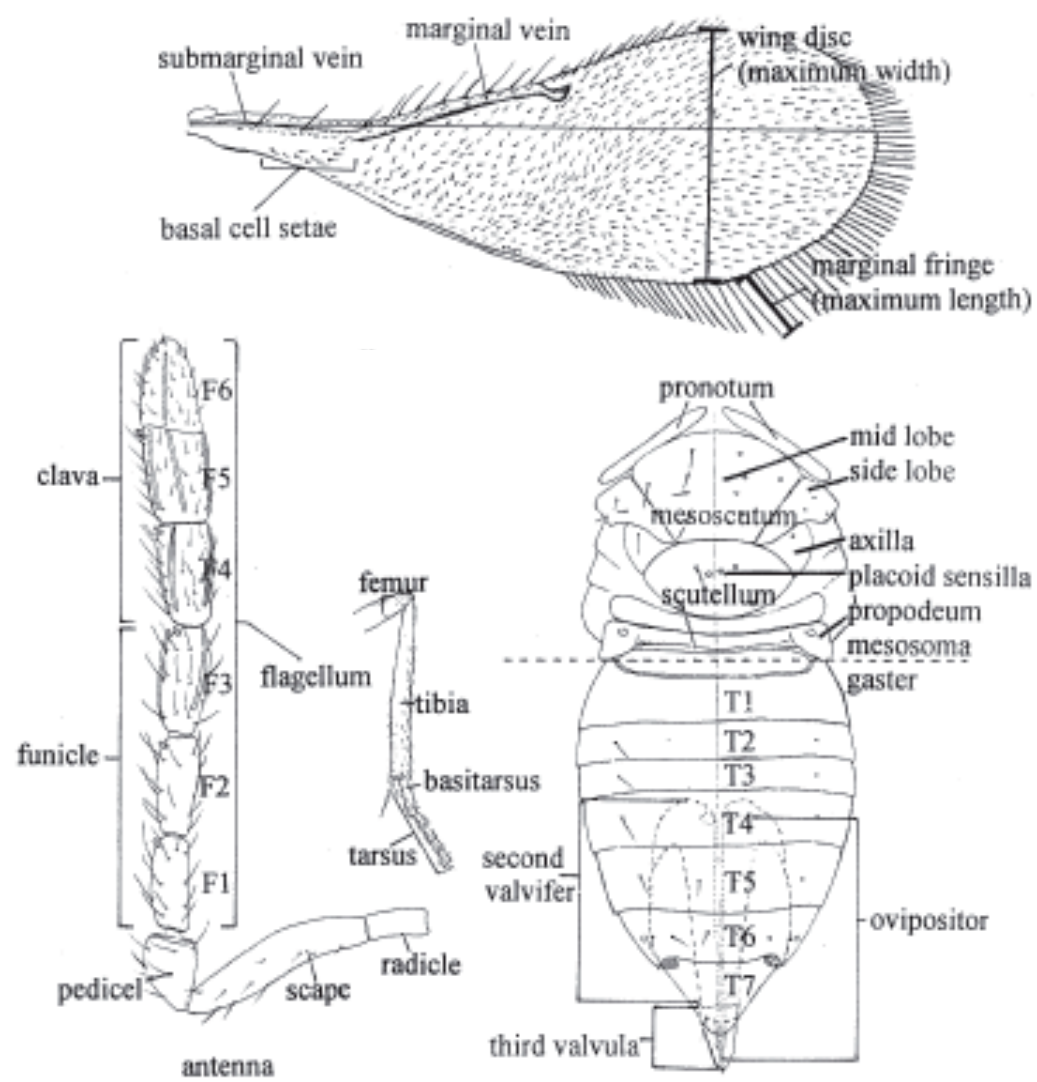

Chart 3.1. Fore wing, antenna, tibia and ovipositor are the more important distinguishing taxonomic characters in the Encarsia genus (extracted from Polaszek et al., 1999). 


\subsection{Second research}

For the study of the parasitoids and predators incidence on CRS population we selected 19 citrus groves belonging to several citrus areas of Eastern Spain in which parasitoid community composition was different. Samples of twigs and fruits were randomly collected from different citrus trees.

In the laboratory samples were separately analyzed under a stereoscopic microscope to determine CRS mortality and parasitism level. Each scale was scored as live, parasitized by Aphytis or Encarsia, mutilated by Aphytis (ex. host-feeding), preyed upon (Fig. 3.5) or dead.
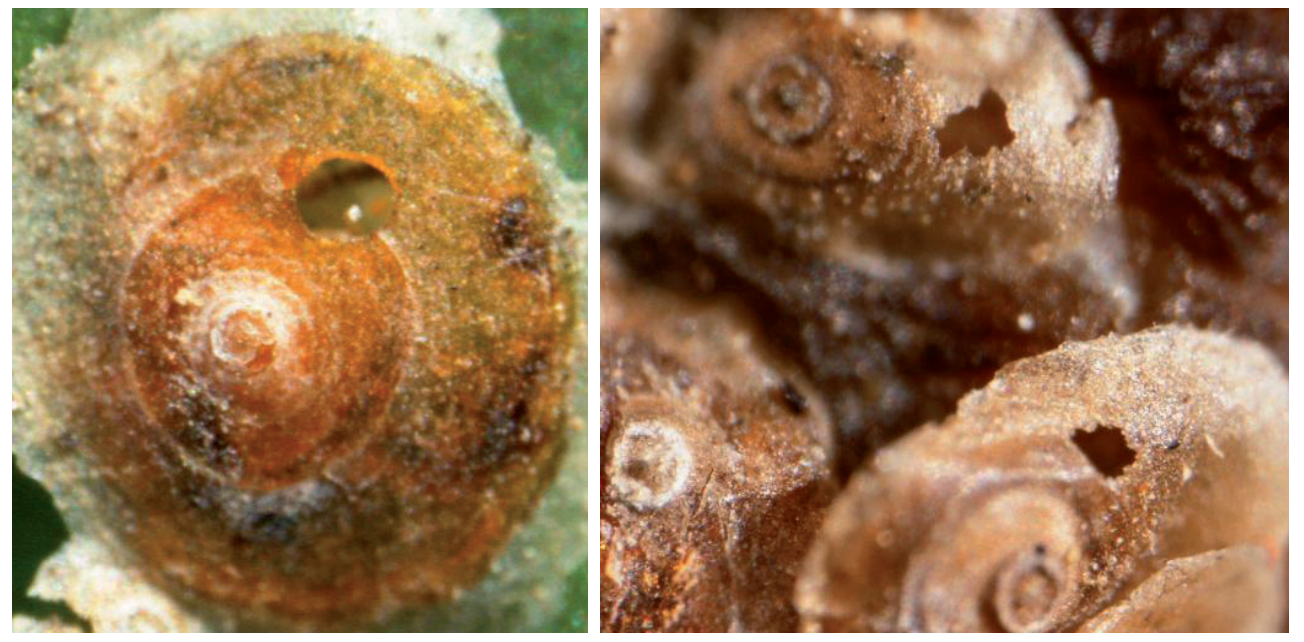

Fig 3.5. Round exit hole in a female CRS scale due to $E$. perniciosi (the CRS residual ectoderm remains present) (left) and irregular chewing holes produced by predators (right).

The average active parasitism by Aphytis spp. was estimated through the observation of live non-parasitized and parasitized CRS in the three stages susceptible to parasitism by Aphytis. The percentage of parasitism attributable to each of the Aphytis species was evaluated through the pupae of the parasitoids observed. Host feeding was evaluated through the observation of mutilation marks on the scale body. The average parasitism by E. perniciosi was estimated on the susceptible CRS stages in which immature parasitoids were detectable with binocular. 
Among dead scales observed, those killed by Aphytis parasitoids, evaluated through the observation of any Aphytis remnant (meconial pellets, exit holes, pupal cases and dead parasitoids) (Fig. 3.6) and those killed by Encarsia (exit holes) were recorded separately to estimate the mortality due to each parasitoid.
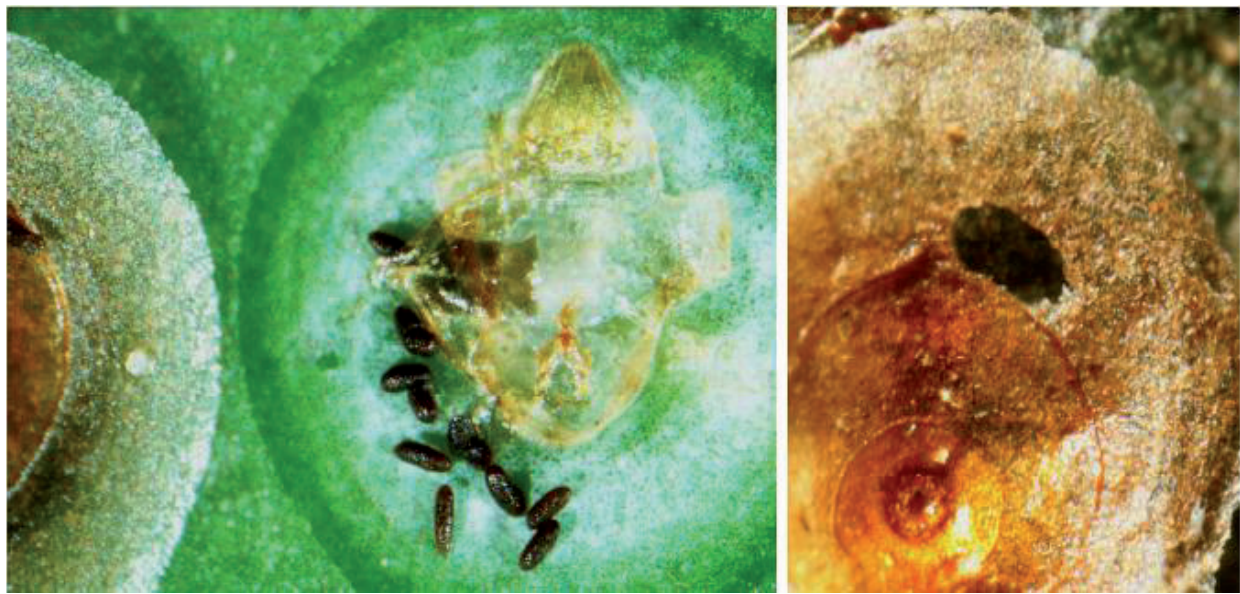

Fig 3.6. Meconial pellets and Aphytis pupal case left under a dead CRS scale (left) and exit hole practiced by the Aphytis in the scale cover (right).

All predators found either preying on the CRS colony or below the scale cover were also identified and recorded. The predatory incidence was estimated as the number of live CRS with a predator present or with predatory chewing symptoms (Fig. 3.7).

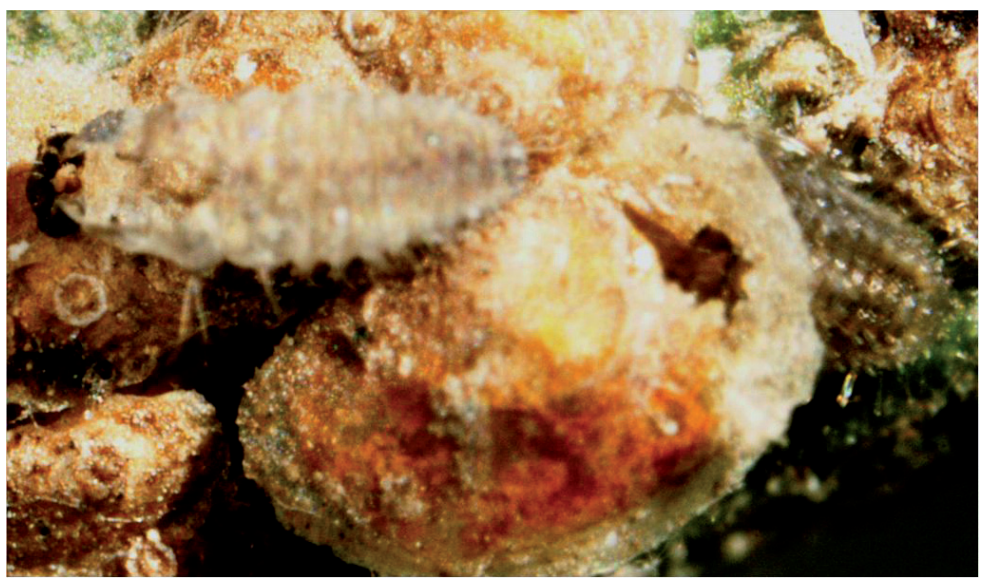

Fig 3.7. Larva (partially visible) and pupal case of the CRS predator L. lophantae next to a chewing hole practiced by this predator in a scale cover. 


\subsection{Third research}

The inland citrus area of Eastern Spain was included in this research. Thus, the study area encompassed three different habitats: inland, coastal and subtropical mediterranean agroecosystems which were sampled in the same manner as the previous surveys. A total of 121 mature orange groves were included in this study.

An introduction program with the two endoparasitoid wasps $C$. bifasciata and E. perniciosi was performed in 19 citrus groves with no previous presence of these parasitoids. Both endoparasitoids were reared on an A. aurantii population growing on butternut squashes (Cucurbita moschata Duchesne) (Fig. 3.8). The procedure consisted in hanging on different trees 2-3 butternut squashes. About 2,000 to 3,000 parasitoids were estimated to emerge from each squash. Parasitized squashes were kindly supplied by Alberto García from the Almassora Insectarium of the Agriculture Department of Valencia Region Government (Conselleria de Agricultura, Spain).

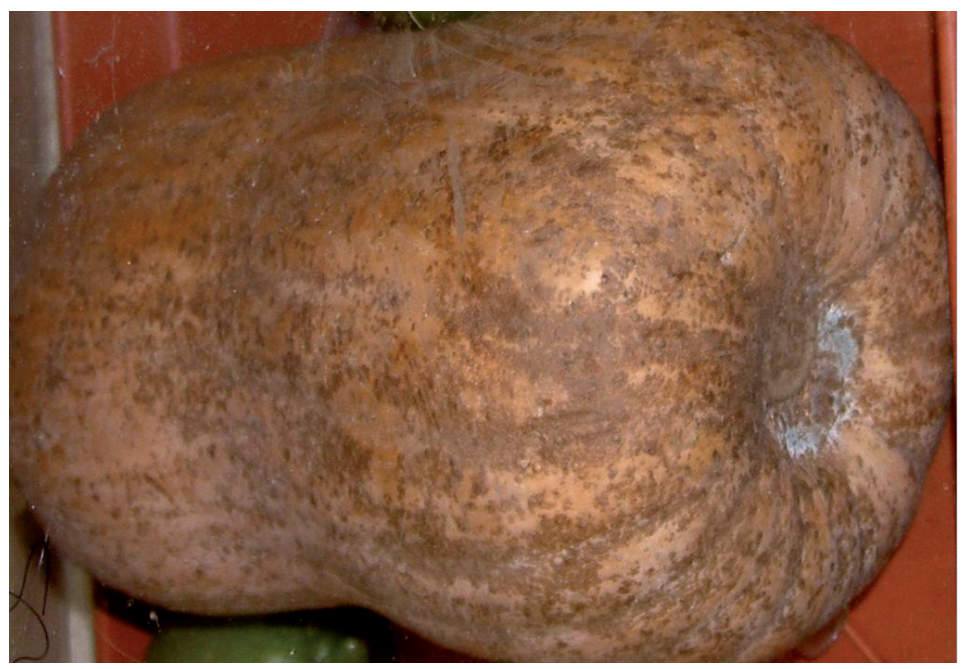

Fig 3.8. An example of the butternut squash growing $A$. aurantii population used for the rearing of $C$. bifasciata and E. perniciosi parasitoids.

One year after parasitoid releases, a second sampling process was conducted in the 19 selected sites to check for the establishment of the parasitoids. We used the same sampling methodology previously described. 


\section{Laboratory experiments}

To determine the intrinsic rate of increase $\left(r_{m}\right)$ under different temperature and RH regimes we used lemon fruits (Citrus limon (L.) Burm. f.) covered over 2/3 with paraffin wax with a semicircular non-paraffined area infested with about 200 second CRS stages. Lemons were individually introduced in cylindrical plastic box ( $5 \mathrm{~cm}$ in diameter) with a fine mesh on the top (Fig. 3.9). A newly emerged female parasitoid (E. perniciosi or C. bifasciata) was introduced in each box and a drop of diluted honey was added as food.
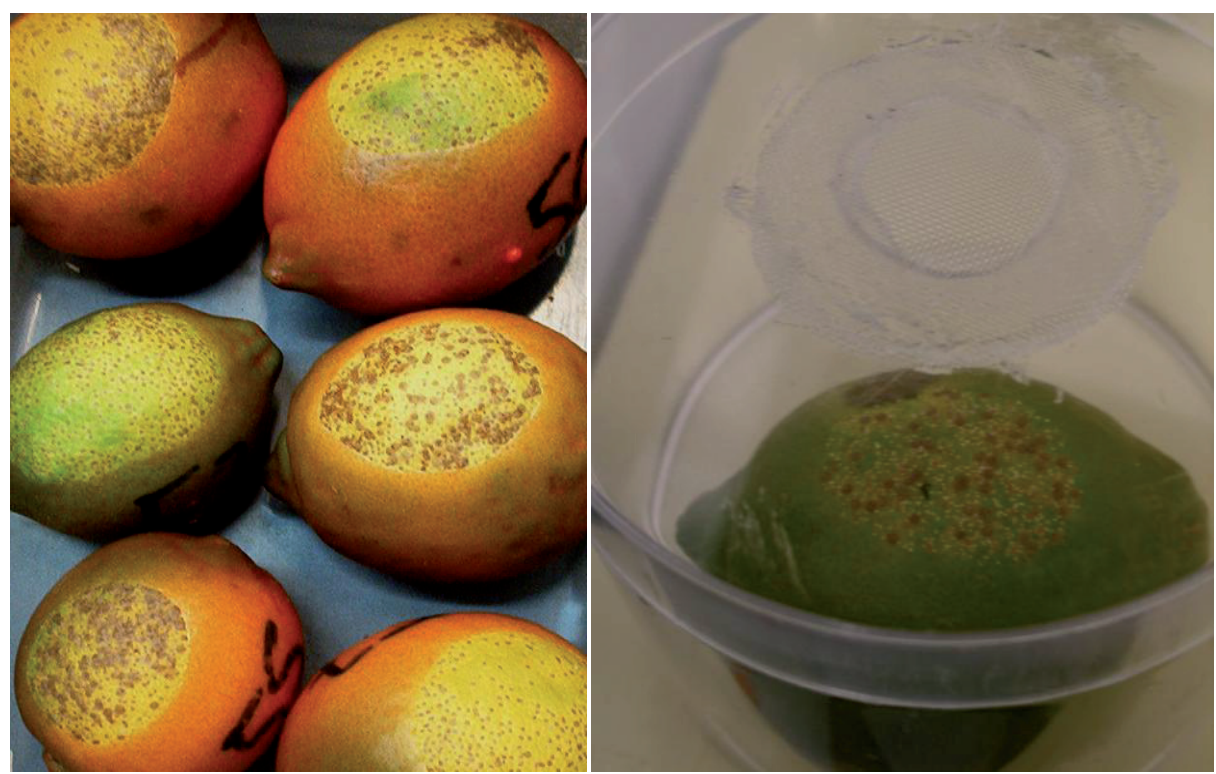

Fig 3.9. California red scale infested lemons fruits covered over $2 / 3$ with paraffin wax (left) and individual box used for progeny experiments with $C$. bifasciata and $E$. perniciosi (right).

Ten female parasitoids of each species were used for each experiment. Every day the lemon was changed for another with the same characteristics until the death of the adult female parasitoid. Lemons were kept under the same conditions until the parasitoid progeny arrived to the adult stage. The adult emergence was checked daily and the approximate development time was estimated as the midpoint of the period between two consecutive observations during which emergence occurred. The total progeny emerged per each female parasitoid was counted and, in the case of $C$. bifasciata, the sex of the emerged insects was recorded. 
To analyse and compare the effect of relative humidity on the adult endoparasitoids longevity, honey provided tubes closed with a fine mesh in both extremes were introduced inside of glass desiccators sealed with grease. A newly emerged endoparasitoid (C. bifasciata or E. perniciosi) was confined in each tube. To maintain the desired constant humidity inside $(25 \%, 45 \%$ or $65 \% \pm 1 \% \mathrm{RH})$ the bottom of each desiccator contained different sulphuric solutions (Fig. 3.10).

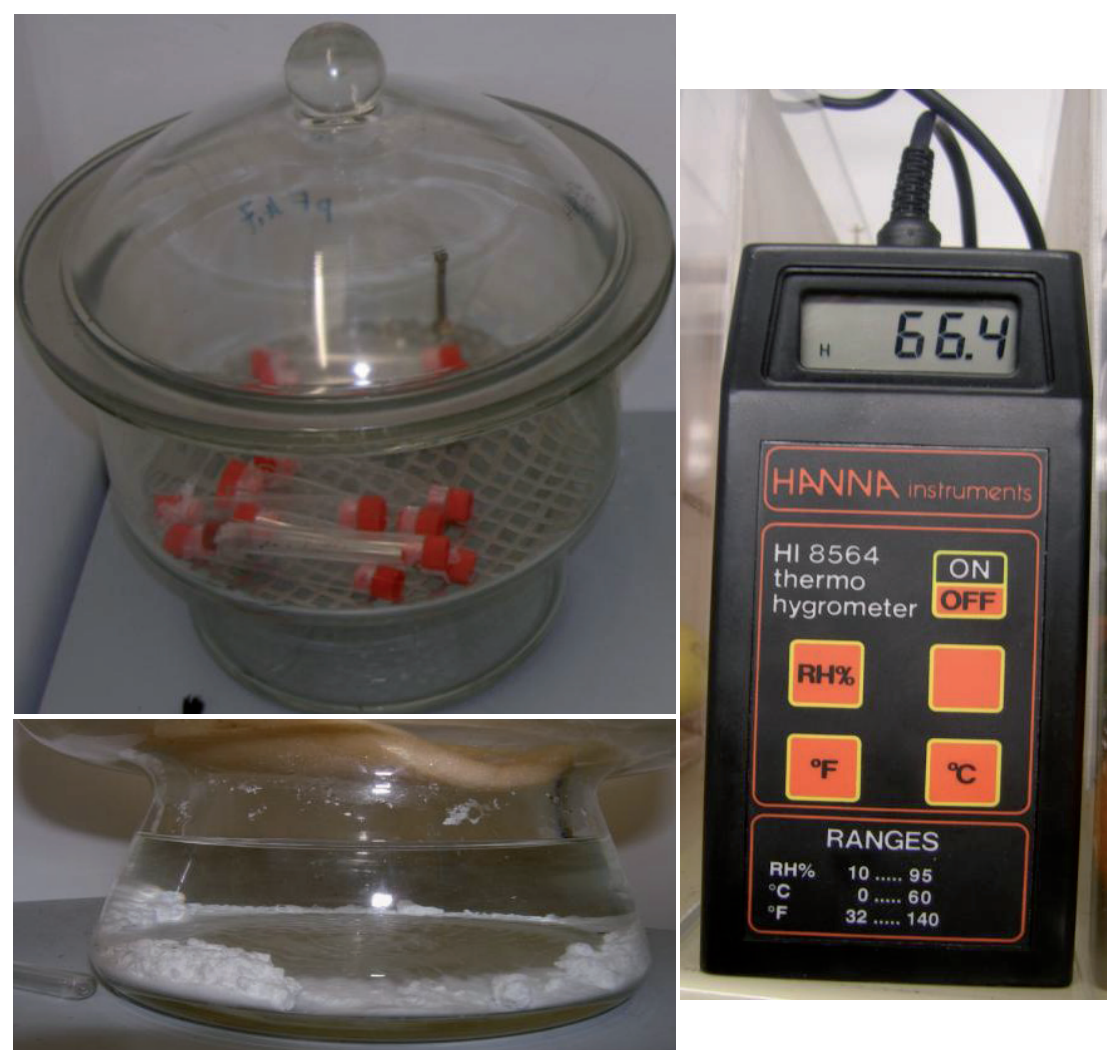

Fig 3.10. A glass desiccator containing tubes with adult parasitoids inside (up left) and detail of the bottom of the desiccator containing a sulphuric solution to maintain desired humidity (down left). Hygrometer used to check the correct humidity inside desiccators (right).

To analyse the influence of temperature on the longevity of adults, newly emerged endoparasitoids were separately introduced inside individual tubes (diameter $1.8 \mathrm{~cm}$, height $10 \mathrm{~cm}$ ) containing diluted honey as food. Tubes were closed 
with a fine mesh at one extreme and a water deposit separated with cotton at the other extreme to allow insect drinking of water at libitum (Fig. 3.11).

Fig 3.11. A tube with a water deposit used for the longevity experiments with adult parasitoids.

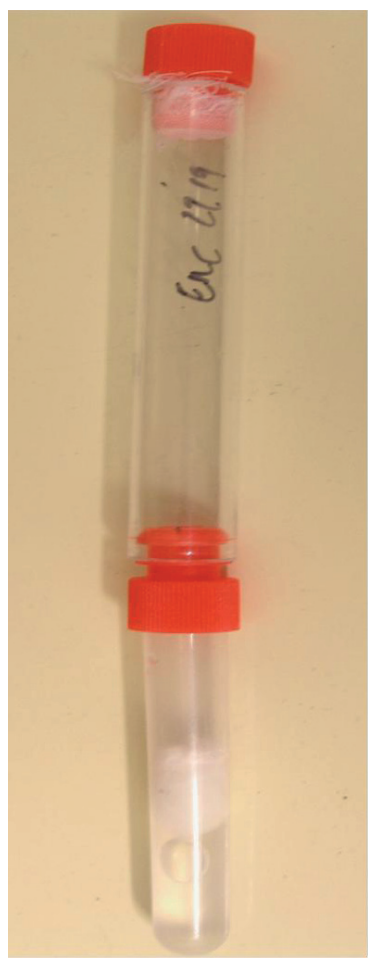





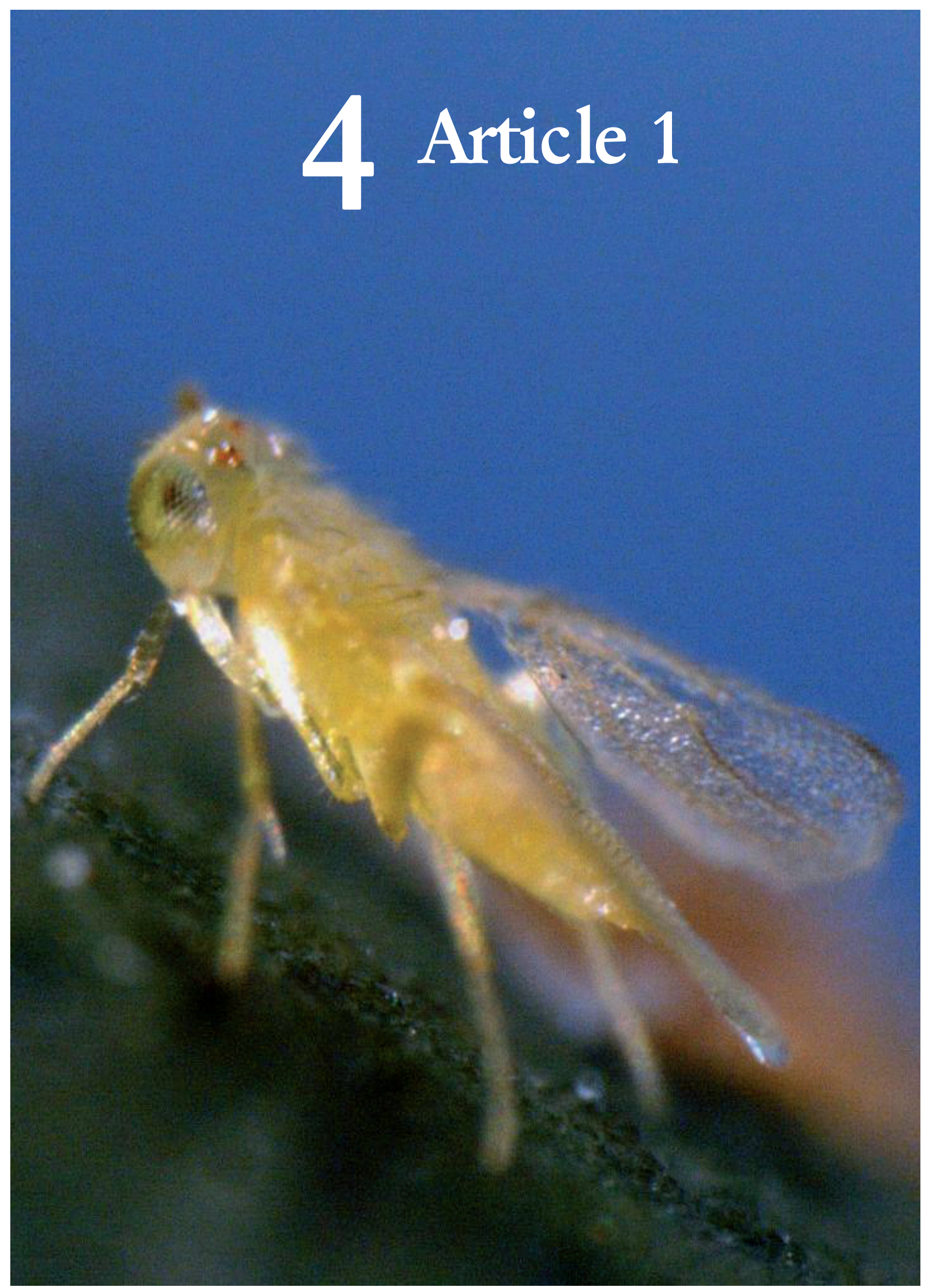





\title{
Parasitoid competitive displacement and coexistence in citrus agroecosystems: linking species distribution with climate*
}

\author{
Juan Sorribas, Raquel Rodriguez and Ferran Garcia-Marí \\ Instituto Agroforestal Mediterráneo, Univ. Politécnica de Valencia, Camino de Vera s/n 46022 Valencia, Spain \\ * As published in Ecological Applications, 20(4), 2010, pp. 1101-1113 (I. F.: 4.28)
}

\begin{abstract}
The introduced parasitoid wasp Aphytis melinus, the most widespread natural enemy of the California red scale and the superior competitor, has displaced the native Aphytis chrysomphali from most citrus areas of the Mediterranean basin and other citrus areas all over the world. However, our extensive survey data on the scale parasitoid populations collected in 2004-2008 show that in large citrus areas of eastern Spain both parasitoids coexist. Using field data from 179 orchards spatially divided in five citrusproducing agroecosystems we examined the mechanisms that could explain displacement or coexistence between both Aphytis species in relation to weather conditions. The distribution and abundance of the parasitoid species is related to the mean summer and winter temperatures and relative humidity of each ecosystem. The relative proportion of A. melinus is higher during the warm months and the abundance of $A$. chrysomphali increases from south to north, being higher in the cooler northern areas. Aphytis melinus has displaced $A$. chrysomphali from hot and dry areas, whereas regions with mild summer temperatures and moderate relative humidity present the optimal conditions for the coexistence of the two parasitoids. The more negative effects of winter temperatures on A. melinus allow the earlier use of the available host resource in late winter and spring by $A$. chrysomphali and the coexistence of both parasitoids in the same orchard via temporal niche partitioning. We combine previous literature on the behavior of Aphytis species in laboratory under different temperature and humidity conditions with our field results to confirm the role of spatiotemporal weather conditions and seasonal changes in host stages on the variation of Aphytis relative abundance and parasitoid coexistence.
\end{abstract}

Key words: Aonidiella aurantii; Aphytis chrysomphali; Aphytis melinus; California red scale; climate effects; interspecific competition; temporal niche partitioning; Valencia Region, Spain. 


\section{1. Introduction}

The hypothesis of competitive displacement in ecological homologues is still highly controversial; sometimes species that have become extinct in one habitat after the introduction of a superior competitor coexist in another habitat with the same competitor. As Hardin (1960) assessed, "ecological differentiation is the necessary condition for coexistence". Intrinsically superior parasitoids can eliminate inferior species by out-competing them for host resources and altering hostparasitoid population dynamics (Hassell 1986) but species may avoid exclusion by employing isolation mechanisms to reduce overlap and partition common resources (Schoener 1974, Diamond 1978). Resource partitioning results in the maximization of habitat availability, the formation of competitive refuges and the facilitation of co-existence (Durant 1998). When there is asymmetric competition for a limiting resource, coexistence typically occurs via a trade-off between competitive ability and some other trait (Tilman and Pacala 1993). The mechanisms that explain coexistence or displacement between parasitoids can be very helpful for applying biological control programs.

Most displacements between arthropods that have been observed were triggered by the introduction or invasion of an exotic species, although environmental factors may predispose a species to being displaced (Reitz and Trumble, 2002). The regulation of pests by natural enemies in poikilotherm organisms is greatly influenced by weather. Climate has a major influence not only on the parasite-host association, but also on interespecific competition between scale parasitoids (Benassy 1961). Direct or indirect climatic influences on the host scale insects or the parasites are important factors in the natural enemy's effectiveness since the dynamics of the same species may vary considerably under different weather regimes. (Huffaker et al. 1971, Huffaker and Gutierrez 1990, Rochat and Gutierrez 2001). The influence of weather on control by natural enemies has been described for the olive scale (Parlatoria oleae (Colvée)) (Rochat and Gutierrez 2001), the oleander scale Aspidiotus nerii (Bouche) (Gutierrez and Pizzamiglio 2007), and other scale parasite associations. 


\subsection{The study system}

The California red scale (CRS) Aonidiella aurantii (Maskell) is a hemipteran armored scale that infests citrus all over the world. Thus, the natural enemy complex of CRS has been widely studied and specially the most effective natural enemies controlling CRS, the aphelinid ectoparasitoids of the Aphytis Howard genus (Rosen and De Bach, 1979). Aphytis melinus DeBach is considered the most successful and widespread biological control agent of this micro-wasp genus (DeBach and Rosen 1991, Foster et al. 1995, Murdoch et al. 1989). Other Aphytis species which can be found in many countries on CRS as native or introduced parasitoids are Aphytis chrysomphali (Mercet) and Aphytis lingnanensis Compere (Luck and Podoler 1985, Dahms and Smith 1994, De Santis and Crouzel 1994, Asplanato and Garcia-Marí 2002).

The Valencia Region (eastern Spain) is the most extended citrus area in Europe and citrus is the most important production in the Spanish Mediterranean agriculture. Aonidiella aurantii was first found as a pest in the locality of Alzira (Valencia) in 1986 (Garcia-Marí et al. 1988, Alfaro et al.1991) and since then it has slowly expanded to almost all the citrus orchards. The parasitoid A. chrysomphali is considered a native species initially parasitizing Chrysomphalus dictyospermi (Morgan) (Mercet 1912). It has also been described parasitizing Chrysomphalus aonidum (Linnaeus), Aonidiella aurantii and Aonidiella citrina (Coquillet) (DeBach and Rosen, 1991). As A. citrina is not present in Spain and C. dictyospermi and $C$. aonidum are nowadays almost absent (Franco et al., 2006), no other hosts are present apart from CRS. Aphytis melinus has been reared and released in the field since 1976 (Melia and Blasco 1980) to prevent a predictable expansion of the pest. Since 1995, A. lingnanensis has also been released in different areas (Verdu 2007). Previous studies in Valencia on A. aurantii parasitoids present in the field have been performed in a reduced number of orchards; observations between 1988 and 1994 yielded almost $100 \%$ of $A$. chrysomphali (Troncho et al. 1992, Rodrigo et al. 1996), whereas in 1999-2000 Pina et al. (2003) obtained 78\% of A. chrysomphali and 22\% of A. melinus.

Here we examine the seasonal abundance and variation of the two most extended California red scale parasitoids throughout the year and their geographical distribution in relation to the weather conditions. We use field data and literature on the behavior of Aphytis species under different temperature and humidity conditions 
to identify the mechanisms of coexistence between A. chrysomphali and A. melinus. The coexistence or displacement between Aphytis species in the field in five spatially divided agroecosystems is examined and related to the climatic characteristics. Mechanisms to explain the coexistence of A. chrysomphali with the superior competitor A. melinus and the niche partitioning between both parasitoids species are analyzed.

\subsection{Background data}

\section{Parasitoid competition}

Since DeBach and Sundby (1963) first described competitive exclusion of A. chrysomphali by $A$. lingnanensis, followed by the displacement of the latter by $A$. melinus in the inland drier citrus areas of California, several papers have dealt with the factors and mechanisms of competitive displacement of these ecological homologues parasitoids after their serial introduction in USA (Podoler, 1981; Luck et al. 1982, Kfir and Luck 1984, Luck and Podoler 1985). DeBach and Sundby theories were based on the supposition that the three Aphytis species have identical ecological niches and thus they are ecological homologues. Previous studies on the competition mechanisms between Aphytis species concluded that the superior competitor A. melinus (Plate 1) displaced the ecological homologue $A$. chrysomphali because it possesses superior intrinsic biological and physiological capabilities, exhibits a higher capacity of dispersion, and moves twice faster when temperatures are higher than $16^{\circ} \mathrm{C}$ (Mclaren, 1976). Further examples of competitive displacement between Aphytis species have been described in other citrus-producing countries like Australia (Smith et al. 1997) and South Africa (Bedford and Cilliers 1994).

Aphytis melinus is considered a superior competitor in the field because it is better adapted to dry and hot climates (Rosen and DeBach 1979). The displacement of Aphytis species by A. melinus has been related to climate adaptability and to other biological differences between species (Kfir and Luck 1979, Huffaker 1990). The effects of temperatures on the different natural enemies of CRS have been widely studied (Abdelrahman 1974 a, b, Atkinson 1983, Kfir and Podoler 1983, Kfir and Luck 1984, Hoffmann and Kennett 1985). DeBach and Rosen (1991) experimentally 
demonstrated that some Aphytis parasitoids can be precluded from exerting adequate control by adverse climatic factors. Bennet (1993) observed that when two Aphytis species were cultured together in laboratory, one species was eventually eliminated: which species survived was influenced by the temperature and humidity regimes of the experiment.

\section{Aphytis chrysomphali displacement in the Mediterranean area.}

In the Mediterranean basin, CRS has been a serious pest for many years in eastern countries. The first recorded infestation was in 1926 in Palestine and later on it was also found in Greece, Cyprus, Turkey, Syria and Egypt (Bodenheimer 1951). It slowly expanded to the west during the second half of the 20th century (Delucchi 1965, Liotta 1970). Aphytis chrysomphali is considered native of the Mediterranean, where it previously parasitized other armored scale species, mainly C. dictyospermi (Mercet 1930, Viggiani 1988). It was first described by Mercet in 1911 in Valencia Region (Spain) and then in Algeria and Tunisia (Mercet 1912). In 1913 A. chrysomphali was reported in Corfu and the Aegean islands (Malenoti 1918). It was later found in France, Italy, Greece, Algeria and Lebanon (Ferrière 1965). Aphytis melinus, which originated in India, was successfully introduced after A. aurantii progressively reached pest status in most Mediterranean citrus producing countries. Following this introduction, displacement of $A$. chrysomphali by A. melinus was reported in most cases. Pelekassis (1974) indicated the successful establishment in Greece in 1962 of the released A. melinus and nine years later, Argyriou (1974) confirmed the total displacement of the native A. chrysomphali in Greece. Guirrou et al. (2003) pointed out $A$. melinus as the main parasitoid of CRS in Morocco, where A. chrysomphali had previously been present (Delucchi 1965). Similar situations were described in Cyprus, Israel, Sicily (Italy), Turkey, Portugal and Egypt (Hafez 1988, Viggiani 1994, Siscaro et al. 1999, Erler and Tunç 2001, Gonçalves et al. 2002, Kamel et al. 2003). In the citrus producing area of Andalucía (southern Spain), with a warmer and drier climate than Valencia Region and where previously $A$. chrysomphali had been widespread (Mercet 1930), A. melinus is nowadays the only parasitoid present (Vela et al. 2007).

However, in some areas around the world, the native or previously existing CRS parasitoids (A. chrysomphali or A. lingnanensis) persisted in small favorable habitats after the introduction of A. melinus, as in coastal areas of Israel and Cyprus, small areas of South Africa and Australia and some humid areas of Uruguay 
(Avidov et al. 1970, Orphanides 1984, Bedford and Grobler 1981, Bedford and Cilliers 1994, Dahms and Smith 1994, Asplanato and Garcia-Marí 2002).

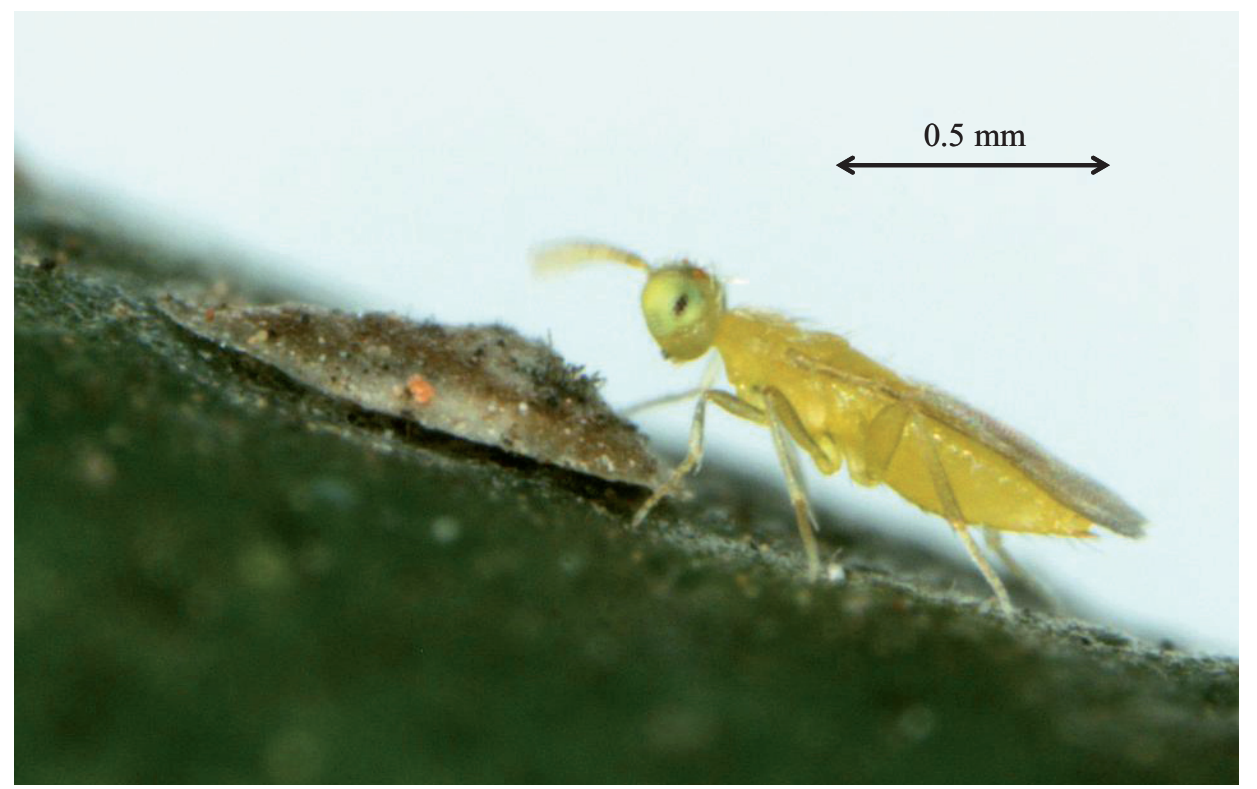

Plate 1. Adult of Aphytis melinus palpitating with its antenna (drumming phase) on a young female scale attached to a twig of a citrus tree. This is a recognition process of the scale prior to oviposition. Photo credit: J. J. Sorribas

\subsection{Materials and methods}

\section{Study area.}

We collected samples from 179 citrus orchards in eastern Spain. Orchards were distributed all over the citrus-growing areas of Valencia Region covering 182 000 hectares along the Mediterranean coast in an almost continuous citrus belt of $400 \mathrm{~km}$ long from north to south and $50 \mathrm{~km}$ wide. The citrus acreage was spatially divided into five surface agroecosystems (labeled Area 1 to Area 5) according to their geographical location from North to South. These ecosystems are independent natural regions that had homogeneous climatic conditions. 
A minimum of 15 orchards were monitored in each of the five citrus ecosystems. The orchards were representative of the cultural practices usually applied by local growers, including organic orchards, orchards managed by IPM practices and orchards under traditional chemical management. The proportion of each agricultural practice was the same in the five agroecosystems studied. All the citrus species or varieties usually cultivated in eastern Spain were included: oranges (Citrus sinensis [L.] Osbeck), lemons (Citrus limon [L.] Burm.), clementine mandarins (Citrus reticulata Blanco), hybrids and satsuma mandarins (Citrus unshiu Markovitch). However, most of the orchards selected for sampling were oranges $(>90 \%)$ and the proportion of this species was similar in the five agroecosystems considered. Two different systems of sampling CRS parasitoids in the field were used: pheromone sticky traps and chromatic sticky traps placed on citrus trees and field-collected samples of branchlets and/or fruits containing A. aurantii.

The citrus area of Valencia presents a typical Mediterranean coastal climate with temperatures very seldom below $0^{\circ} \mathrm{C}$ during winter due to the sea influence, high average relative humidity ( $>60 \%)$ but dry summer, especially in the southern areas. The climatic data for each agroecosystem (area) are provided in the Table 1, together with the approximate period in which $A$. aurantii started and completed the invasion of the area (Garcia-Marí et al., 1988; Rodrigo et al., 1996; Alfaro et al., 1999; Moner, 2000; Verdú and Pina, 2002; Garcia-Marí, 2003). These data were obtained from the Valencian Research Institute climatic database (available online) ${ }^{1}$.

\section{Pheromone and chromatic field traps.}

Between June 2005 and May 2006, traps coated with adhesive (Frutect, RonPal Ltd., Israel) collected from 100 commercial citrus orchards in full production were observed. The orchards were included in a survey net established by the Agriculture Department of the Valencia Region Government (Citrus Phytosanitary Survey Project - Plan de Vigilancia Fitosanitaria de Cítricos) to monitor citrus pest populations all along the Valencia citrus area (availabe online) ${ }^{2}$. CRS pheromone traps, as well as several color traps, are known to be effective on the capture of Aphytis parasitoids (Sternlicht 1973, Moreno et al. 1984).

1 (http://estaciones. ivia.es/)

2 (http://www.agricultura.gva.es/rvfc/index.htm) 
Pheromone traps consist of a 19 x $19 \mathrm{~cm}$ tent-type white cardboard with a synthetic A. aurantii female pheromone lure (AgriSense BSC, UK.) attached to the center underside ceiling. Yellow sticky traps are non-pheromone rectangular plastic traps of $15 \times 20 \mathrm{~cm}$. The two traps were randomly placed in different trees in each orchard. Every week 50 of the traps were collected and replaced, so that each trap spent 14 days in the field. The pheromone lure was changed every six weeks. In the laboratory the parasitoids captured were located in the traps under the binocular stereoscope, extracted, mounted and identified under the microscope.

The CRS males were also captured on the A. aurantii pheromone sticky straps and counted. Orchards with low capture levels of males or parasitoids were excluded from the study, so that finally a total of 60 orchards remained. The CRS infestation level on fruits and branchlets was evaluated in the orchards by direct observation in the field of 80 fruits and 40 branchlets per orchard. These observations were made every two weeks throughout the year for branchlets and when fruits were present.

\section{Laboratory experiments.}

During the period November 2004 to March 2008, samples of branchlets (twigs with leaves) and/or fruits infested with $A$. aurantii were randomly collected from 134 citrus orchards located throughout the citrus-producing areas of Valencia Region. Along this period each orchard was sampled once per season (spring, summer, fall and winter) except on those orchards in which CRS was eliminated by chemical treatments or where captures of Aphytis were lower than 10 specimens. In this case the orchard was replaced for another orchard in the same area. Thus, at the end of the whole sampling period, four samples from each orchard were obtained. A similar number of orchards were sampled for each agroecosystem considered and samples were regularly distributed along the sampling period. Branchlet samples consisted of $35-45$ young branches $(0.5$ to 1.5 years old $) \sim 30 \mathrm{~cm}$ long with leaves taken from different trees. Samples of 20-35 fruits were collected when $>3 \mathrm{~cm}$ in diameter and were kept in the rearing cages to capture emerging adult parasitoids.

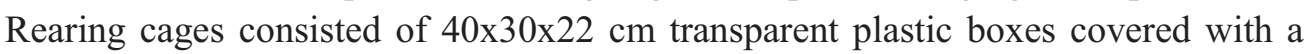
gauze and maintained inside climatic chambers $\left(26-28^{\circ} \mathrm{C}, 60 \%\right.$ relative humidity, 16:8 $\mathrm{hr}$ photoperiod) for 20 days to allow all parasitoids develop to adults ( $A$. melinus needs $\sim 18$ days from egg to adult at $26^{\circ} \mathrm{C}$ ). Adult parasitoids were captured on yellow $12 \times 12 \mathrm{~cm}$ sticky traps placed inside the cages or collected dead from the 
bottom of the cage. The total number of parasitoids was counted and a maximum of 100 parasitoids per sample was identified.

In order to speed up the identification procedure we looked for an alternative to the traditional method described by Rosen and DeBach (1979) for the digestion of Aphytis. Several methods and products were tested to eliminate the glue and digest the insects (xylene from $1 \mathrm{~h}$. to $48 \mathrm{~h}$., lactic acid, potassium hydroxide solution and Nesbitt liquid). The option chosen was $20 \mathrm{~h}$. xylene $+30 \mathrm{~min}$. Nesbitt digestion $+1 \mathrm{~min}$. heating under flame which provides fast location and observation of insects since they are not completely digested and their red heads are easily identified (the body of Aphytis is digested faster than the head).

\section{Data Analysis.}

For the estimation of A. melinus sex-ratio we only considered the insects captured on rearing cages since field sticky traps always capture much more males than aspirator-vacuum techniques or direct counting of parasitoids on plant material and thus are not representative of the male proportion in the field (Reeve and Murdoch 1986; R. F. Luck, personal communication).

The correlation between the mean proportion of A. melinus of each agroecosystem with the most significant weather parameters was performed using Pearson product-moment correlation coefficient. Within each matrix the pairwise correlations between variables were calculated. The statistical significance of these correlations was assessed using standardized tables.

Differences in the proportion of $A$. melinus between the orchards of the five agroecosystems were analyzed using one-way analysis of variance (ANOVA); differences between the three years were analyzed using two-way ANOVA, with year and agroecosystem as main factors. Comparison between captures of CRS males and proportion of $A$. melinus, comparison of different types of traps and the influence of the season of the year on A. melinus sex-ratio were analyzed using oneway ANOVA. Means were compared using Fisher's LSD test. Data on the proportions were arcsine square-root transformed before ANOVA to stabilize the variance. Statistical analyses were performed using Statgraphics 5.1 program (Statgraphics 2000). 


\subsection{Results}

The two ectoparasitoid species are present together in most of the citrus orchards with California red scale. Aphytis melinus was present in most samples, showing the successful establishment and widespread dispersion of this species in the Valencia Region 30 years after its introduction. A total of 21276 parasitoids were identified from trap captures and emerging from plant material, $51 \%$ belonged to Aphytis melinus and $47 \%$ to Aphytis chrysomphali. The presence and establishment of the endoparasitoid Encarsia perniciosi (Tower) was observed in a small humid valley of La Marina County (Area 4). The 503 specimens of $E$. perniciosi captured represent only $2 \%$ of the total number of parasitoids but $13 \%$ of the parasitoids captured in this area, where it was present in most of the samples. Aphytis lingnanensis, not previously documented in Spain as naturally occurring on A. aurantii, was also found (107 insects) in two neighbouring orchards of Area 4. These orchards were very close to the point where a release of $A$. lingnanensis was carried out in 1995 (Verdú, 2007). No other A. lingnanensis specimens were captured out of these orchards.

\section{Spatial distribution.}

There are slight climatic differences between the five areas sampled. Average air temperatures increases from north to south. Areas 4 and 5 have higher minimum temperatures and Area 5 is the most arid. Rainfall is higher in Areas 3 and 4. Average winter temperatures stay around $10^{\circ} \mathrm{C}$ in Areas 1 to 3 but reach higher than $11^{\circ} \mathrm{C}$ in Areas 4 and 5. In Areas 1 to 3 the number of days per year with average temperatures $<10^{\circ} \mathrm{C}$ is also higher (54.7-58.4 respectively) than in Areas 4 and 5 (36.8 and 34.7).

The mean relative percentage of $A$. melinus (in relation to A. chrysomphali) for each area (Areas 1-5) was 24\%, 39\%, 48\%, 67\% and 95\%, respectively (Fig. 1). Area 4, in which A. lingnanensis and E. perniciosi appear, exhibits semitropical conditions with much lower number of days with temperatures $<10^{\circ} \mathrm{C}$. 


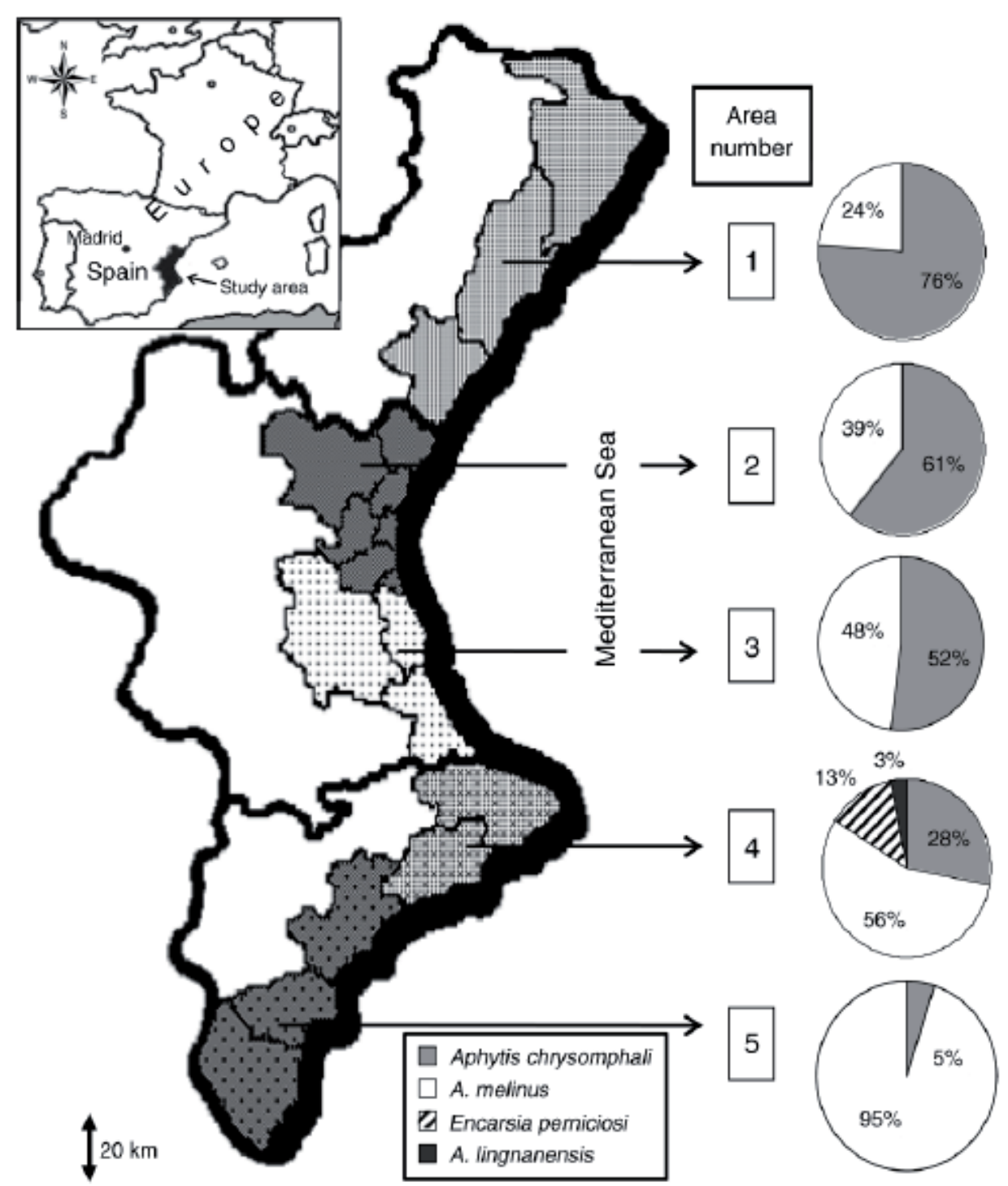

Fig. 1. Relative percentage of Aonidiella aurantii parasitoids in five areas (see Materials and methods: Study area), which includes all citrus acreage of Valencia Region, eastern Spain. The sampling period was 2004-2008. Lines inside shaded areas delimit counties.

The correlation between the mean percentages of A. melinus of each agroecosystem with the weather parameters is shown in Table $\mathbf{1}$ together with the most significant weather parameters. 
Table 1. Climatic data of the five Valencia Region citrus areas for the period 2002-2007 (annual mean of 5-8 weather stations) and invasion period of Aonidiella aurantii (California Red Scale, CRS) for each area. Correlation (r) with the percentage of Aphytis melinus is reported in the last row.

\begin{tabular}{|c|c|c|c|c|c|c|c|c|c|}
\hline \multirow[b]{2}{*}{ Area number and name } & \multicolumn{5}{|c|}{ Mean temperature $\left({ }^{\circ} \mathrm{C}\right)$} & \multirow{2}{*}{$\begin{array}{l}\text { No. days } \\
<10^{\circ} \mathrm{C}\end{array}$} & \multirow{2}{*}{$\begin{array}{c}\text { Mean } \\
\text { relative } \\
\text { humidity }(\%) \\
\end{array}$} & \multirow{2}{*}{$\begin{array}{c}\text { Mean } \\
\text { rainfall } \\
(\mathrm{mm})\end{array}$} & \multirow{2}{*}{$\begin{array}{c}\text { CRS } \\
\text { invasion } \\
\text { period }(\mathrm{yr})\end{array}$} \\
\hline & Overall & Minimum & Maximum & Winter & Summer & & & & \\
\hline 1) $\mathrm{La} \mathrm{Pla}$ & 16.6 & 11 & 21.9 & 9.8 & 24. & 58.4 & 61.8 & 584 & 2001-2007 \\
\hline & 16 & 11 & & & 24 & & & & 000 \\
\hline La Safor & 17. & 11 & 23 & 10 & 25 & & 6. & 6 & 1986-1991 \\
\hline 4) La Marina & 17.7 & 12.8 & 23.3 & 11.3 & 25.6 & 36 & 63 & 692 & 1988-1995 \\
\hline 5) Bajo Segura & 17.9 & 12.8 & 23.5 & 11.2 & 25.8 & 34.7 & 60.1 & 302 & 1997-2006 \\
\hline$r$ & $0.97^{* *}$ & $0.92^{*}$ & $0.89^{*}$ & $0.88^{*}$ & $0.91^{*}$ & $0.91^{*}$ & 0.42 & 0.53 & \\
\hline
\end{tabular}

Notes: Climatic data are from the Valencian Agriculture Research Institute climatic database (http://estaciones. ivia.es). For details on the five citrus areas see Materials and methods: Study area. CRS invasion period was obtained from previous works (Garcia-Mari et al. 1988, Rodrigo et al. 1966, Alfaro et al. 1999, Moner 2000, Verdú and Pina 2002, Garcia-Marí 2003) and our field data. Pearson correlation coefficients $(r)$ show the relationship between each climatic parameter and the percentage of $A$. melinus.

$* P<0.05 * * P<0.01$

Aphytis melinus has almost completely displaced the native $A$. chrysomphali from the southern of Valencia Region (Area 5), but both Aphytis species coexist in different proportions in all other citrus ecosystems. The relative proportion of $A$. melinus increases progressively from Area 1 (northernmost of the five agroecosystems) to Area 5 showing a statistical correlation between the proportion of $A$. melinus in the orchards belonging to each area and the mean temperature of the area $\left(F_{4,168}=30.90, P<0.0001\right)$. The mean temperature of each agroecosystem presented the better Pearson correlation coefficient of the weather parameters analyzed $(r=0.97)$. In some orchards in Areas 1 and 2 the proportion of $A$. chrysomphali reaches more than $90 \%$ (Fig. 2A). No significant changes on Aphytis proportions for each area between the years were observed when we compared the three years $(2005,2006$ and 2007) in which samples were collected. Thus the differences in the proportion of $A$. melinus between the areas remained constant for the three years (two-way ANOVA; $F_{2,14}=1.00, P=0.409$ for years; $F_{4,14}=47.82, P$ $<0.0001$ for agroecosystem; Fig. 2B). 


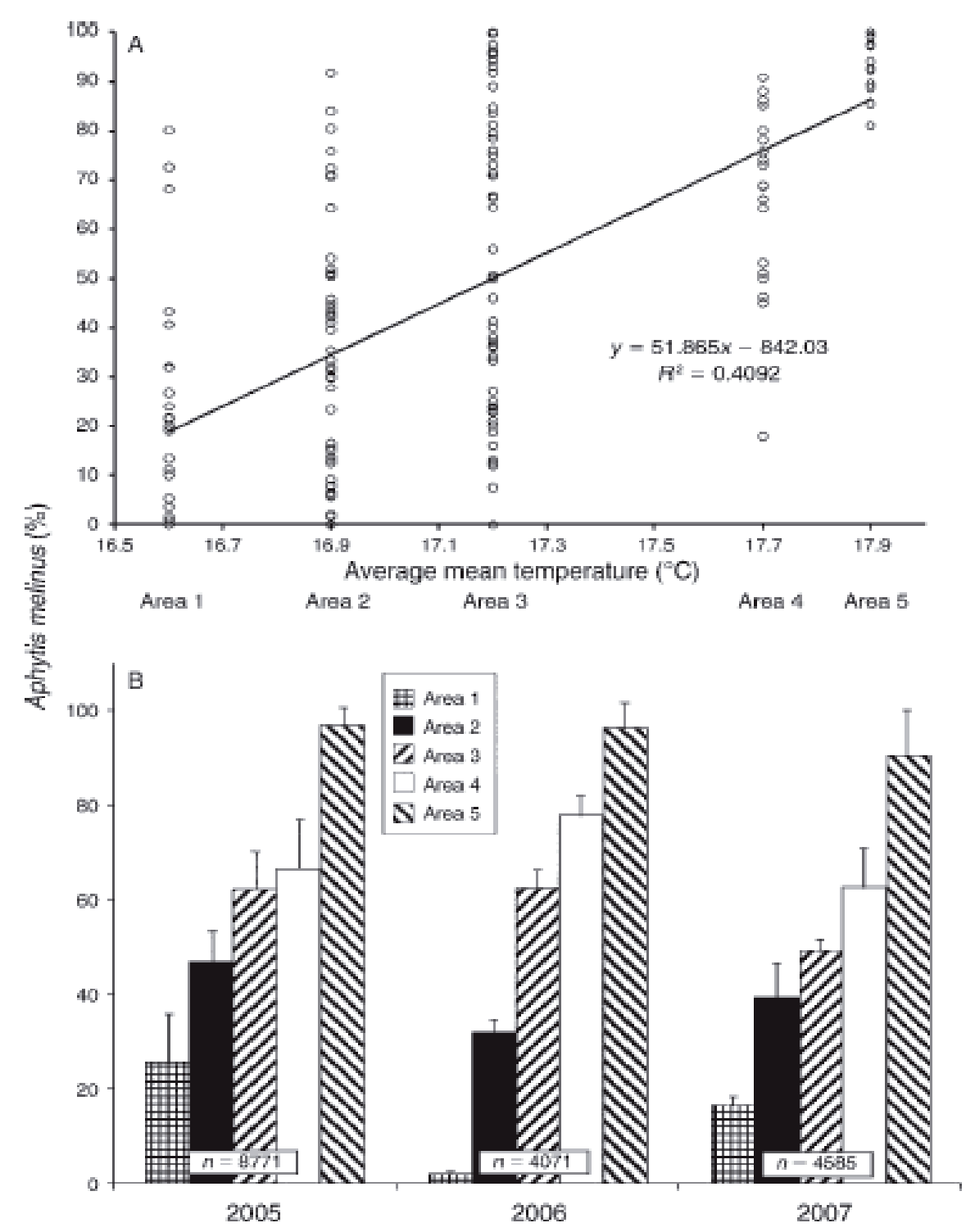

Fig. 2. Distribution of the percentage of $A$. melinus for the five areas into which Valencia citrus surface is divided (see Materials and methods: Study area) (A) in each orchard (the average mean temperature of each area is also indicated) and (B) for each year (average and SE; only fullsampled years are represented). Sampling methods were field traps and rearing cages with plant material. The differences are significant between areas $(\mathrm{P}<0.0001)$ and not significant between years. We considered only the 173 orchards in which $>10$ Aphytis were captured. 


\section{Seasonal abundance.}

The field traps show almost no captures of parasitoids during January and February and a steadily increasing Aphytis captures from March, reaching maximum levels in August for A. melinus and in October for A. chrysomphali. Captures of $A$. aurantii adult males show two main peaks, in June-July and September (Fig. 3A). For the rearing cages the analysis of seasonal changes in Aphytis abundance and species composition throughout the year was carried out in branchlet samples, as this is a substrate where citrus red scale populations are present all the year round. In this case, captures are observed throughout the year, reaching a peak in August for $A$. melinus and in November for A. chrysomphali (Fig. 3B).
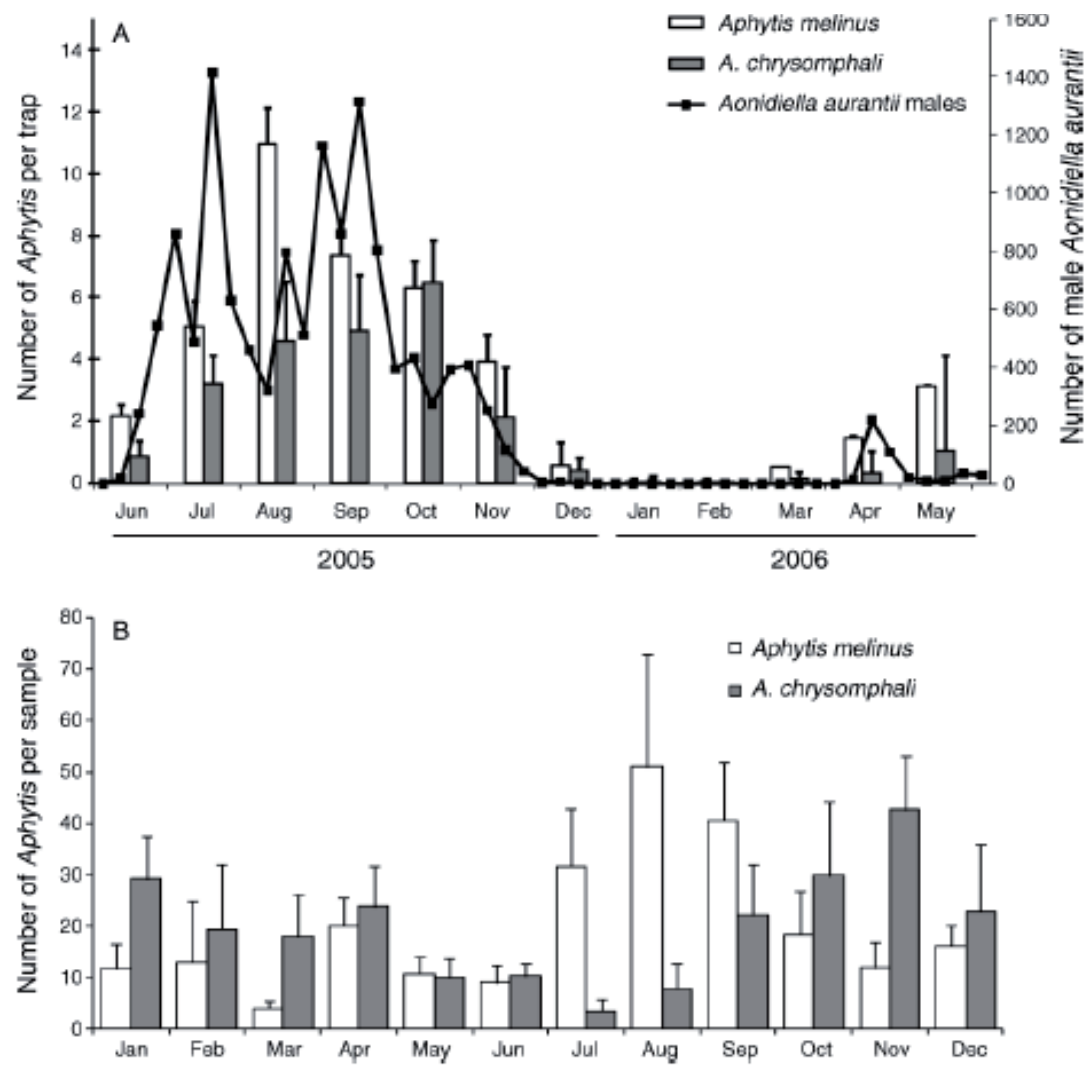

Fig. 3. Monthly average (and SE) captures of Aphytis melinus and A. chrysomphali along five areas of Valencia Region (see Materials and methods: Study area) (A) in pheromone traps placed in 60 citrus orchards between June 2005 and May 2006 (weekly captures of males of Aonidiella aurantii are represented by the line) and (B) in rearing cages from samples of branchlets during the period 2004-2007. 
Overall, the total data from field traps and rearing cages show that the relative proportion of Aphytis species varied throughout year, Aphytis chrysomphali being more abundant during the cooler periods of the year (late autumn and winter) and A. melinus predominant during the summer (Fig. 4).

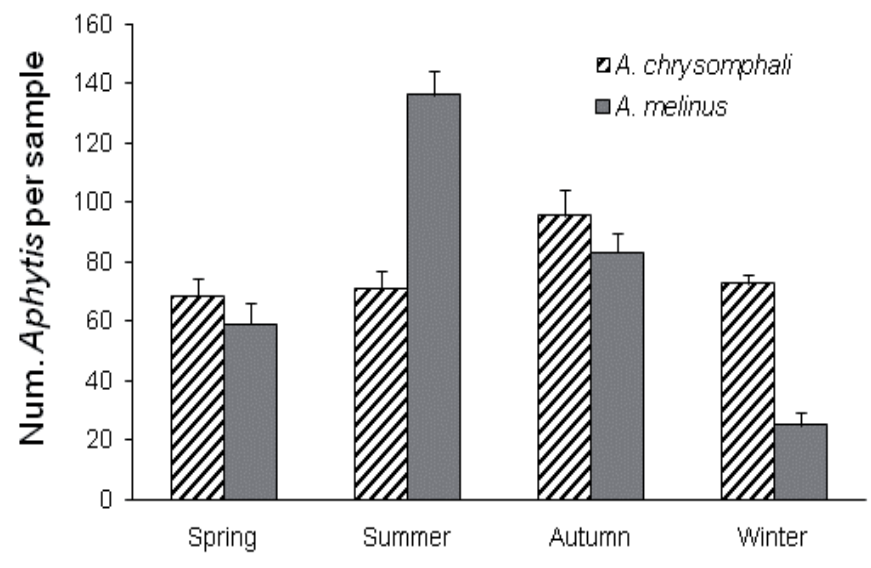

Fig. 4. Influence of season of the year on abundance of Aphytis species. Data are from field traps and rearing cages (fruits and branchlets) in 173 orchards sampled throughout Valencia Region (Spain) between 2004 and 2008. Values are averages and $\mathrm{SE}$.

Both Aphytis species were present in most of the groves sampled and those that contained only one species of parasitoid were rare. When the two species of Aphytis are present in the same orchard our observations show that their monthly relative abundance can fluctuate widely throughout the year.

\section{Relationship of CRS-Aphytis species.}

There was a significant relation $\left(F_{1,53}=8.77, P=0.0051\right)$ between the proportion of A. melinus in a particular orchard and the level of captures of adult male CRS (an index of the abundance of parasitoid hosts). We found that when the number of males is low (which means low to moderate infestation levels for $A$. aurantii) most of the parasitoids are A. melinus, but when the captures of CRS males are high both Aphytis species are usually present. In the first case the number of captures was $<2000$ insects per trap and year for most of the samples but in the second the number of males captured was usually much higher (Fig. 5). 


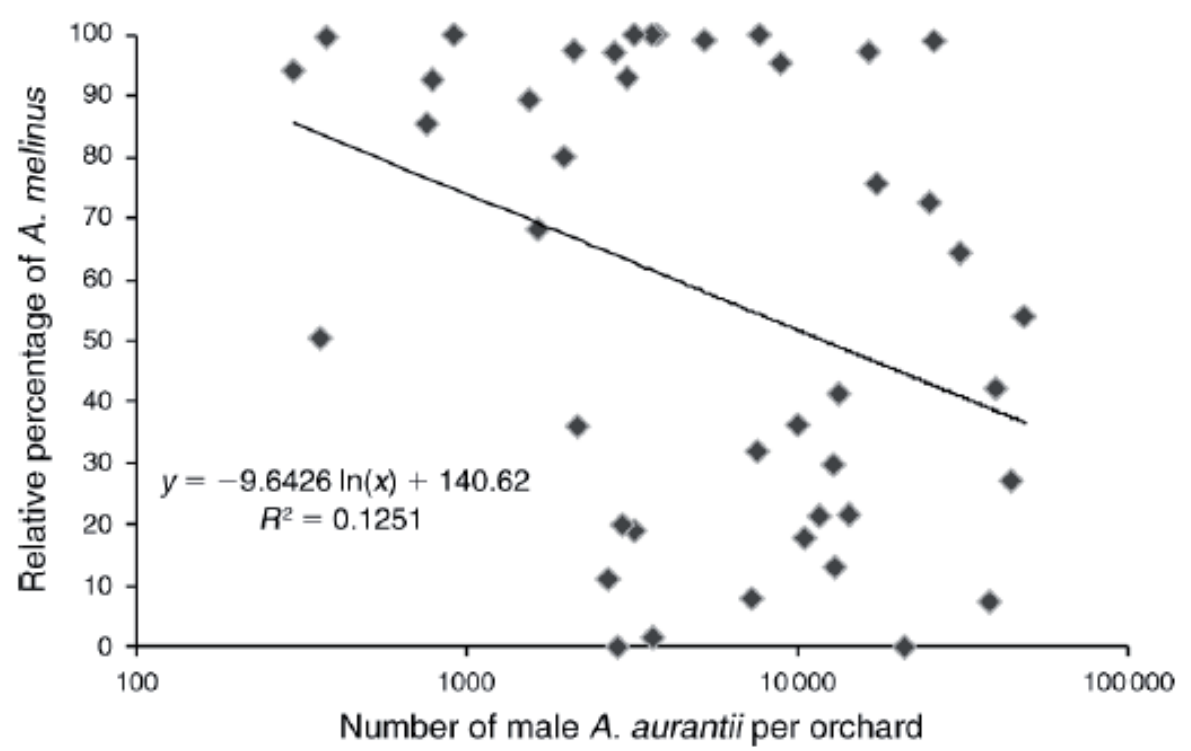

Fig. 5. Relationship between total number of males of Aonidiella aurantii per orchard and year and the percentage of A.melinus/total Aphytis in the orchard. Insects were captured on field traps in 60 citrus orchards distributed throughout Valencia Region during the period June 2005-May 2006 (we considered only orchards in which $>300$ CRS males or $>20$ Aphytis were captured per year).

All the E. perniciosi specimens captured were females. Most $A$. chrysomphali observed were females, only 48 males $(0.5 \%)$ were found among 8862 adults identified. The sex-ratio (M:F) of A. melinus was male-biased in most of the samples. The percentage of $A$. melinus males in the field traps was $79 \%$, but data from the rearing cages indicate the percentage of males at $56 \%$. A seasonal analysis of the sex-ratio of A. melinus in rearing cages showed that it was lower in spring and summer, with values approaching $53 \%$ and increased significantly to $64 \%$ in the winter months $\left(F_{3,78}=1.8, P=0.16\right)$, while spring and autumn gave intermediate values (Table 2). 
Table 2. Influence of season of the year on the sex-ratio of Aphytis melinus in the Valencia Region, eastern Spain.

\begin{tabular}{lcc}
\hline \hline Season & Number of samples & A. melinus males (\%) $\dagger$ \\
\hline Summer & 45 & $53.6^{\mathrm{a}} \pm 2.3$ \\
Spring & 40 & $52.3^{\mathrm{a}} \pm 4.2$ \\
Autumn & 65 & $57.9^{\mathrm{ab}} \pm 2.1$ \\
Winter & 47 & $64.2^{\mathrm{b}} \pm 4.7$ \\
\hline
\end{tabular}

Note: Data are from rearing cages traps (see Materials and methods: Laboratory experiments) capturing $>20 \mathrm{~A}$. melinus during the period 2004-2007. Values followed by the same letter do not differ significantly (Fisher LSD test, $\mathrm{P}<0.05$ ). Error terms are SE.

\subsection{Discussion}

Early research on CRS parasitoids in the Mediterranean area showed that the native $A$. chrysomphali, which was the most widespread and important species during the first half of the 20th century, had been displaced from most citrus producing areas after the introduction of A. melinus in the early 1960s, which increasingly spread from the east of the Mediterranean basin to the west. This confirms A. melinus as the better competitor and corroborates previous displacement of other Aphytis species found in the United States. This may be the reason why coexistence mechanisms between A. melinus and A. chrysomphali had not been previously studied. However, our results show that the replacement of $A$. chrysomphali by $A$. melinus has not occurred in eastern Spain. This is possibly the only large citrus area where, a long time after the introduction of A. melinus, A. chrysomphali remains present in large numbers. If we compare the fast adaptation and establishment of $A$. melinus and the subsequent displacement of $A$. chrysomphali in citrus areas like California, Greece or Sicily (DeBach and Sundby 1963, Argyriou 1974, Siscaro et al. 1999), with the long period of time since A. melinus was released in eastern Spain, there are apparently factors in this area which prevent the displacement of $A$. chrysomphali and allow the coexistence of both parasitoids. The mechanisms that explain this coexistence can be found through the combination of previous literature on biological adaptations to temperature of the two Aphytis species and the spatiotemporal variation of Aphytis abundance related to weather conditions we have found in the field. 
CRS is a relatively recent pest in eastern Spain and it could be argued that the process of displacement of $A$. chrysomphali by A. melinus has not yet concluded. But our observations show a similar proportion of A. melinus and A. chrysomphali than those reported in previous experimental studies in the same areas (Troncho et al., 1992; Rodrigo et al., 1996; Pina et al., 2003). Also the percentage of A. melinus in our results remains constant for the three years sampled. Further proof that $A$. melinus is not expanding with time can be deduced from the fact that the relative abundance of A. melinus is no higher in the first area invaded by CRS (late 1980s, area 3 ) than in area 5 , where the invasion process has recently been completed (see Table 1).This suggests that there has not been much change in the relative proportion of both parasitoids in the Valencia area during the last years and the parasitoid population can be considered stabilized.

Valencia citrus acreage shows significant differences in winter and summer temperatures between the cooler north (Areas $1-3$ ) and the warmer south (Areas 4 and 5) areas. The number of days per year with average temperatures $<10^{\circ} \mathrm{C}$ is lower in Areas 4 and 5, where the proportion of A. melinus is higher. The temperature of $10^{\circ} \mathrm{C}$ lies between the thresholds of development for A. melinus and A. chrysomphali, $8.5^{\circ} \mathrm{C}$ and $11^{\circ} \mathrm{C}$, respectively (Abdelrahman, 1974b). The distribution of Aphytis species in the Mediterranean coast of Spain apparently follows this climatic pattern, A. melinus being the overall predominant species in the hottest and driest Area 5 and A. chrysomphali increasing its relative proportion as temperature decreases and/or rainfall increases. There is thus a direct relation between temperature and humidity of one area and the dominant Aphytis species. Cooler winter temperatures and not too hot summers are the main differences between Valencia citriculture and other citrus areas where A. melinus has totally displaced A. chrysomphali. Rochat and Gutierrez (2001) found a similar relation between two parasitoids of the olive scale (Parlatoria oleae (Colvée)) that showed how cool regimes were favourable for one species, high temperatures for the other and both species coexisted at intermediate temperatures.

Kfir and Luck (1984) suggested that susceptibility of A. chrysomphali to high temperatures and low relative humidity was probably the main reason why it was replaced by A. melinus in California. In the experiments carried out by Kfir and Podoler (1983) total progeny production of A. melinus was high at the maximum temperature tested, $32^{\circ} \mathrm{C}$, whereas A. chrysomphali failed to oviposit at this temperature. In our survey data we found that dry areas with hot summer 
temperatures are preferred by $A$. melinus, which is able to complete the displacement of $A$. chrysomphali but areas with mild summer temperatures have a significant abundance of $A$. chrysomphali. In addition, this parasitoid usually appears near coastal or humid zones in Florida, Cyprus, Australia or Uruguay (Muma, 1959; Orphanides, 1984; Dahms and Smith, 1994; Asplanato and Garcia-Marí, 2002) where summer temperatures are milder and humidity higher than in inland areas.

In temperate regions, enforced hibernation during the winter often brings several complications that may prevent the effectiveness of an introduced species (Clausen 1952). Adverse winter temperatures may cause an interrupted period of sufficient length to prevent an otherwise efficient natural enemy from controlling its host as occurred in some areas of California with A. lingnanensis (DeBach et al. 1955) due to pupae mortality in winter. Also, it has been experimentally demonstrated that $A$. melinus females held at $15^{\circ} \mathrm{C}$ for just 24 hours produced only 11 progeny per female as compared with 28 progeny produced at $27^{\circ} \mathrm{C}$ (DeBach 1969). Cool temperatures during winter in Areas $1-3$ are probably responsible for the low A. melinus population observed in our data during this season. Our results demonstrate that declining temperatures during autumn and winter have a greater negative effect on $A$. melinus than $A$. chrysomphali, since the indigenous $A$. chrysomphali is more cold-tolerant and better adapted to these weather conditions. When both parasitoids coexist in the same orchard, A. melinus is more abundant during summer and $A$. chrysomphali during winter. This seasonal alternation in parasitoid dominance could be one of the reasons why the more efficient parasitoid A. melinus has not completely displaced A. chrysomphali in most Valencia citrus orchards.

Another negative effect of cold winter temperatures on A. melinus population was the high percentage of males generated $(>60 \%)$, while lower percentages were observed during spring and summer. Similar results were found in California citrus orchards by Hoffmann and Kennett (1985). As it was assessed by Abdelrahman (1974a), when cool temperatures prevail, the thelytoky of $A$. chrysomphali might give an advantage over the arrhentokous A. melinus since the former produce female progeny a few hours after emergence, whereas A. melinus produces only male progeny until fertilization. Since flying range, males-females encounters and mating ratio are reduced under these conditions, the progeny will consist of more males than females. Aphytis melinus originated in India and is 
adapted to hot climates, so the cooler winter conditions of Valencia affect negatively its survival, reproduction and sex-ratio.

Excluding Area 5, in most citrus groves both parasitoids coexist most of the year, thus the two parasitoids have a considerable degree of overlap in their niches. However, A. chrysomphali, that is smaller in size, utilizes smaller hosts than $A$. melinus to produce progeny since it prefers male scales followed by second instar females, whereas A. melinus prefers mainly third instar females (Muma 1959, Foster et al. 1995, Pina et al. 2003, Pekas et al. 2008). When a new generation of CRS starts in spring, the younger host preference and the better cold resistance will give a competitive advantage to $A$. chrysomphali since its feeding resource is available earlier than for $A$. melinus. This lead time allows $A$. chrysomphali to emerge earlier in the year and to build up sufficient densities such that $A$. melinus cannot exclude it. Hence, under some climatic conditions theoretical displacement of $A$. chrysomphali by $A$. melinus is transformed into coexistence due to temporal niche partitioning between both parasitoids. Thus, although a considerable degree of competition between both Aphytis species may occur, both species perform in a compensatory manner throughout the year, hot periods being preferred by A. melinus and cool periods by A. chrysomphali. The combination of both Aphytis parasitoids could result in better CRS control since, as suggested by Amarasekare (2000), two natural enemies that coexist via temporal niche partitioning or a dispersal-competition tradeoff may provide optimum control of a pest through complementary action. Two of the necessary mechanisms for interespecific competition displacement, higher proportion of female offspring and resource preemption, are not accomplished by $A$. melinus during winter and early spring in temperate regions.

On the other hand, the superior search ability and capacity of dispersion exhibited by A. melinus (Mclaren 1976, Kfir and Podoler 1983) could explain why we observed a higher relative proportion of A. melinus than A. chrysomphali in orchards with low scale density but when the scale density was high both Aphytis species were present (see Fig. 5).

Humidity is another limiting factor for parasitoid effectiveness; $A$. lingnanensis survives at $20 \%$ of RH a third as long as at $80 \%$ (Rosen and DeBach, 1979). There are big differences in rainfall and humidity between Area 4 and Area 5. This could explain why E. perniciosi is only found in Area 4, which has the more rain and where the temperature rarely drops below zero (with an average minimum

$$
-100-
$$


temperature of $12.8^{\circ} \mathrm{C}$ it is the only area in Valencia where tropical fruits are grown). This endoparasitoid usually parasitizes CRS in humid or semitropical areas all over the word (DeBach et al. 1971; Furness et al. 1983; Asplanato and Garcia-Marí 2002), but is not common in the Mediterranean. Its spreading to other Mediterranean citrus areas could thus be limited by its climatic requirements and would explain why it has not appeared in other regions of this survey. It is also well-known that $A$. lingnanensis needs high relative humidity (Rosen and DeBach 1979; Kfir and Luck 1984) and this could explain why it established around the release point in 1995. However, it's still not clear why it has not expanded to other parts of Area 4.

Aphytis chrysomphali reaches its population peak in October and A. melinus in August, before the second male peak of the host A. aurantii in September. However, captures of Aphytis were very low before the first peak of males of $A$. aurantii in late spring. Consequently, mass releases of Aphytis parasitoids in biological control programs should be focused on late spring and early summer, when naturally occurring parasitoids are usually scarce and the scale population is available for parasitism. Releases of new parasitoid species should consider their maximum and minimum temperature threshold and the humidity requirements and be focused on suitable climatic areas.

In conclusion, in contrast with what was widely believed, $A$. chrysomphali is not always displaced after the successful introduction of the better competitor $A$. melinus since they are not strict ecological homologues. Displacement of the former or coexistence of both parasitoids depends on climatic conditions of each agroecosystem: in temperate regions $A$. melinus and A. chrysomphali can coexist through temporal niche partitioning that allow the alternation of the predominant species throughout the season and the host sharing between the two Aphytis species. Regions with mild summer temperatures and moderate to high relative humidity present the optimal conditions for A. chrysomphali; under these circumstances the proportion of $A$. chrysomphali can be similar or higher than the proportion of $A$. melinus. The colonization of new cooler areas in the north by A. melinus may be slowed down by its susceptibility to cool temperatures and its low progeny and male biased sex-ratio in winter. We can state that weather changes throughout the season in temperate regions can allow an ecological inferior parasitoid to coexist in the same habitat with the superior homologue parasitoid due to its different adaptation to cold and hot periods. 


\section{Ackowledgements}

The authors wish to thank Eugenia Rodrigo of the Ecosistemas Agroforestales Department of the Valencia Polytechnic University (Spain) for her help with Aphytis identification, Robert Luck and William Murdoch from the University of California (USA) for information on the sex-ratio, and Alejandro Tena and Rosa Vercher from the Instituto Agroforestal Mediterráneo (Valencia, Spain) and Joan van Baaren from the ECOBIO Institute (Rennes, France) for their recommendations and critical review. Special thanks to all Citrus Phytosanitary Survey staff for the field trap samples and the two anonymous reviewers who provided helpful comments on the manuscript. English corrections were carried out by Centro de Lenguas of the Valencia Polytechnic University. This work was supported by the AGL2005-07155-C03-03 project of the Spanish Ministry of Education and Science.

\subsection{Literature cited}

Abdelrahman, I. 1974a. The effect of extreme temperatures on California red scale, Aonidiella aurantii (Mask.) (Hemiptera: Diaspididae) and its natural enemies. Australian Journal of Zoology 22:203-212.

Abdelrahman, I. 1974b. Growth, development and innate capacity for increase in Aphytis chrysomphali Mercet and A. melinus DeBach, parasites de California red scale, Aonidiella aurantii (Mask.), in relation to temperature. Australian Journal of Zoology 22:213-230.

Alfaro, F., Cuenca, F. and C. Ferrer. 1991. Piojo Rojo de California, nueva plaga preocupante. Biología y control. Phytoma España 25:10-22.

Alfaro, F., Cuenca, F. and M. Esquiva. 1999. Problemática actual del piojo rojo de California en la C. Valenciana. Comunitat valenciana agraria 95:54-60.

Amarasekare P. 2000. Coexistence of competing parasitoids on a patchily distributed host: local vs. spatial mechanisms. Ecology 81:1286-1296.

Argyriou, L. C. 1974. Data on the biological control of citrus scales in Greece. OILB/WPRS Bulletin 3:89-94. 
Asplanato, G. and F. Garcia-Marí. 2002. Parasitismo de la cochinilla roja californiana Aonidiella aurantii (Homoptera: Diaspididae) en la zona citrícola sur de Uruguay. Boletín Sanidad Vegetal Plagas 28:5-20.

Atkinson, P.R. 1983. Environmental factors associated with fluctuations in the numbers of natural enemies of a population of red scale, Aonidiella aurantii (Maskell) (Hemiptera: Diaspididae). Bulletin of Entomological Research 73:417-426.

Avidov, Z., M. Balshin, and U. Gerson. 1970. Studies on Aphytis coheni, a parasite of the California red scale. Aonidiella aurantii, in Israel. Entomophaga 15:191-207.

Bedford, E.C.G. and C.J. Cilliers. 1994. The role of Aphytis in the biological control of armored scale insects on citrus in South Africa. Pages 143-179 in D. Rosen editor. Advances in the study of Aphytis. Intercept Limited, UK.

Bedford, E.C.G. and J.H. Grobler. 1981. The current status of the biological control of red scale, Aonidiella aurantii (Mask.), on citrus in South Africa. Pages 616-620 in Proceedings of the International Society of Citriculture.

Benassy, C. 1961. Contribution a l'etude de l'influence de quelques facteurs écologiques sur la limitaion des pullulations de cochenille-diaspines. Annales des Épiphyties 12 :1-157.

Bennet, F. D. 1993. Do introduced parasitoids displace native ones? Florida Entomologist 76:54-63.

Bodenheimer, F. S. 1951. Citrus Entomology in the Middle East. Dr. W. Junk Publishers, The Hague, Holland.

Clausen, C. P. 1952. Biological control of insect pests. Calif. Citrog. 37:182-206.

Dahms, E.C. and D. Smith. 1994. The Aphytis fauna of Australia. Pages 245-255 in D. Rosen editor. Advances in the study of Aphytis. Intercept Limited, UK.

De Santis, L. and I. S. Crouzel. 1994. Species of Aphytis ocurring in the Neotropical region and their role in biological control. Pages 256-277 in D. Rosen editor. Advances in the study of Aphytis. Intercept Limited, UK.

DeBach, P. and A. Sundby. 1963. Competitive displacement between ecological homologues. Hilgardia 34:105-166. 
DeBach, P. 1969. Biological control of Diaspine scale insects on citrus in California. Pages 801-822 in Proceedings of the 1st International Citrus Symposium.

DeBach, P. and D. Rosen. 1991. Biological control by natural enemies, $2^{\text {nd }}$ ed. Cambridge University Press, UK.

Delucchi, V. 1965. Notes sur le pou de Californie (Aonidiella aurantii Maskell) au Moroc. Annales de la Société Entomologique de France 1:740-788.

Diamond, J. M. 1978. Niche shifts and rediscovery of interspecific competition. American Scientist 66:322-331.

Durant, S. M. 1998. Competition refuges and coexistence: an example from Serengeti carnivores. Journal of Animal Ecology 67:370-386.

Erler, F. and I. Tunç. 2001. A survey (1992-1996) of natural enemies of Diaspididae species in Antalya, Turkey. Phytoparasitica 29:299-305.

Ferrière, C. 1965. Hymenoptera Aphelinidae d'Europe et du Bassin Mediterranéen. Faune de l'Europe et du Bassin Méditerranéen 1. Masson et Cie, Paris, France.

Forster, L., R. Luck, and E. Grafton-Cardwell. 1995. Life stages of California red scale and its parasitoids. University of California, Division of Agriculture and Natural Resources, 21529, Oakland, CA.

Franco, J. C., F. Garcia-Marí, A. P. Ramos and M. Besri. 2006. Survey on the situation of citrus pest management in Mediterranean countries. IOBC/WPRS Bull. 29 (3): 335 345 .

Furness, G.O., G.A. Buchanan, R.S. George, and N.L. Richardson. 1983. A history of the biological and integrated control of red scale, Aonidiella aurantii on citrus in the Lower Murray Valley of Australia. Entomophaga 28:199-212.

Garcia-Marí, F. 2003. Biología y control del "poll roig” de California en cítricos valencianos. Phytoma España 153:120-123.

Garcia-Marí, F., A. Ribes, J. Costa-Comelles, and F. Ferragut. 1988. Detección, muestreo y control de poblaciones del piojo rojo de California Aonidiella aurantii. Reunión Gr. Trabajo Cítricos. Ser. Prot. Veg. Pages 9-15 in $\mathrm{M}^{\mathrm{o}}$ de Agricultura, editor. Reuniones anuales de los grupos de trabajo fitosanitarios. Madrid, Spain. 
Gonçalves, I., C. Soares, and J.E. Fernández. 2002. A cochonilha pinta vermelha (Aonidella aurantii Maskell): resultados de estudos de prospecção e caracterização bioecológica. Pages 509-516 in Proceedings Congresso Nacional de Citricultura de Portugal.

Guirrou, Z., I. El Kaoutari, and A. Boumezzough. 2003. Contrôle des populations d'Aonidiella aurantii (Maskell) en vergers d'agrumes au Maroc. Fruits 58:3-11.

Hafez, M.B. 1988. Population fluctuations on parasites of California red scale, Aonidiella aurantii (Mask.) in Alexandria. Journal of Applied Entomology 106:183-187.

Hardin, G. 1960. The competitive exclusion principle. Science 131: 404-416.

Hassell, M. P. 1986. Parasitoids and population regulation. Pages 201-224 in J. Waage and D. Greathead, editors. Insect Parasitoids. Academic Press, London.

Hoffmann, R.W. and C.E. Kennett. 1985. Effects of winter temperatures on the sex ratios of Aphytis melinus in the San Joaquin valley of California. Entomophaga 30:125-132.

Huffaker, C.B., Messenger, P.S. and P. DeBach. 1971. The natural enemy component in natural control and the theory of biological control. Pages 16-67 in C.B. Huffaker, editor. Biological control. Plenum Press, New York.

Huffaker, C. B. 1990. Effects of Environmental Factors on Natural Enemies of Armored Scale Insects. Pages 205-220 in D. Rosen, editor. Armored scale insects. Their biology, natural enemies and control. Elsevier. Oxford, New York, Tokyo.

Kamel A., S. Abd-Rabou, N. Hilmy, S. Allam, and M. Moustafa. 2003. Seasonal abundance of certain Aphytis species from Egypt. Egyptian Journal of Agricultural Research 81:1009-1023.

Kfir, R. and R.F. Luck. 1979. Effects of constant and variable temperature extremes on sex ratio and progeny production by Aphytis melinus and A. lingnanensis (Hymenoptera: Aphelinidae). Ecological Entomology 4:335-344.

Kfir, R. and R.F. Luck. 1984. Effects of temperature and relative humidity on development rate and adult life span of three Aphytis species (Hym. Aphelinidae) parasitising California red scale. Zeitschrift fur Angewandte Entomologie 97:314-320.

Kfir, R., and H. Podoler. 1983. Effect of temperature and parasite density on three species of Aphytis, parasitising California red scale. Researches on Population Ecology 25:69-80.

$$
-105-
$$


Luck, R.F., H. Podoler, and R. Kfir. 1982. Host selection and egg allocation behavior by Aphytis melinus and A. lingnanensis: comparison of two facultatively gregarious parasitoids. Ecological Entomology 7:397-408

Luck, R.F., and H. Podoler. 1985. Competitive exclusion of Aphytis lingnanensis by A. melinus: Potential role of host size. Ecology 66:904-913.

Malenotti, E. 1918. I nemici naturale della "Bianca-Rossa" (Chrysomphalus dictyospermi Morg.). Redia 13:17-53.

Mclaren, I.W. 1976. A behavioural study of Aphytis chrysomphali (Mercet) and Aphytis melinus DeBach (Hymenoptera: Aphelinidae) parasitic on California red scale, Aonidiella aurantii (Maskell) (Homoptera: Diaspididae). $\mathrm{PhD}$ Thesis, La Trobe University, Australia.

Melia, A., and J. Blasco. 1980. Los cóccidos perjudiciales a los cítricos de Castellón y sus parásitos. Fruits 35:551-554.

Mercet, R.G. 1912. Un parasito del 'poll roig'. Boletín de la Real Sociedad Española de Historia Natural 12:135-140.

Mercet, R.G. 1930. Los Afelínidos de España. Revista de Biologia Forestal y Limnologia 2:29-54.

Moner, J. P. 2000. Consideraciones sobre el control del piojo rojo de California, Aonidiella aurantii (Maskell). Comunitat Valenciana Agraria 16:16-19.

Moreno, D. S., W. A. Gregory, and Tanigoshi, L. K. 1984. Flight Response of Aphytis melinus (Hymenoptera: Aphelinidae) and Scirtothrips citri (Thysanoptera: Thripidae) to Trap Color, Size and Shape. Environmental Entomology 13:935-940.

Muma, H. 1959. Natural control of Florida red scale. Journal of Economic Entomology 4:577-586.

Murdoch, W. W., R. F. Luck, S. J. Walde, J. D. Reeve, and D. S. Yu. 1989. A Refuge for Red Scale Under Control by Aphytis: Structural Aspects. Ecology 70:1707-1714.

Orphanides, G.M. 1984. Competitive displacement between Aphytis spp. (Hym.: Aphelinidae) parasites of the California red scale in Cyprus. Entomophaga 29:275-281.

$$
-106-
$$


Pelekassis, C. D. 1974. Historical review of biological control of citrus scale insects in Greece. OILB/WPRS Bulletin 3:14-20.

Pekas A., A. Aguilar, and F. Garcia-Marí. 2008. Host size availability for Aphytis parasitoids in field populations of California red scale Aonidiella aurantii, in Eastern Spain citrus groves. OILB/WPRS Bulletin 38:34-40.

Pina T., B. Martínez, and M.J. Verdú. 2003. Field parasitoids of Aonidiella aurantii (Hem.: Diaspididae) in Valencia (Spain). OILB/WPRS Bulletin 26:91-96.

Podoler, H. 1981. Effects of variable temperatures on responses of Aphytis melinus and A. lingnanensis to host density. Phytoparasitica 9:179-190.

Reeve, J.D. and W.W. Murdoch. 1986. Biological control by the parasitoid Aphytis melinus, and population stability of the California red scale. Journal of Animal Ecology 55: 1069-1082.

Reitz S. R. and J. T. Trumble. 2002. Competitive displacement among insects and arachnids. Annual Review of Entomology 47:435-465.

Rochad, J. and Gutierrez, A. P. 2001. Weather-mediated regulation of olive scale by two parasitoids. Journal of Animal Ecology 70:476-490.

Rodrigo, E., P. Troncho, and F. Garcia-Marí. 1996. Parasitoids of three scale insects (Hom.: Diaspididae) in a citrus grove in Valencia, Spain. Entomophaga 41:77-94.

Rosen, D. and P. DeBach. 1979. Species of Aphytis of the World (Hym.: Aphelinidae). Dr. W. Junk Publishers, The Hague, Holland.

Schoener, T. W. 1974. Resource partitioning in ecological communities. Science 185:27-38.

Siscaro, G., S. Longo, and S. Lizzio. 1999. Ruolo degli entomofagi di Aonidiella aurantii (Maskell) (Hom.: Diaspididae) in agrumeti siciliani. Phytophaga 9:41-52.

Smith, D., G. A. C. Beattie, and R. Broadley. 1997. Citrus pests and their natural enemies: integrated pest management in Australia. Department of Primary Industries, Queensland, Australia.

Statgraphics 2000. Statgraphics plus for Windows, version 5.1. Statistical Graphics, Rockville, Maryland, USA. 
Sternlicht, M. 1973. Parasitic wasps attracted by the sex pheromone of their coccid host. Entomophaga 18:339-342.

Tilman, D. and S. Pacala. 1993. The maintenance of species richness in plant communities. Pages 13-25 in R. Ricklefs and D. Schluter, editors. Species diversity in ecological communities. University of Chicago Press, Illinois, USA.

Troncho, P., E. Rodrigo, and F. Garcia-Marí. 1992. Observaciones sobre el parasitismo en los diaspinos Aonidiella aurantii (Maskell), Lepidosaphes beckii (Newman) y Paralatoria pergandei (Comstock) en una parcela de naranjo. Boletín Sanidad Vegetal de Plagas 18:11-30.

Vela, J., M. J. Verdú, A. Urbaneja, and J. Boyero. 2007. Parasitoides de Aonidiella aurantii (Maskell) en plantaciones de cítricos en el sur de España. Proceedings V Congreso Nacional de Entomología Aplicada, Cartagena, Spain.

Verdú, M. J. and T. Pina. 2002. Control biológico del piojo rojo de California, Aonidiella aurantii (Mask.). Phytoma España 140:18-26.

Verdú, M. J. and T. Pina. 2007. Establecimiento y dispersión de Aphytis melinus y A. lingnanensis (Hym.: Aphelinidae), dos parasitoides introducidos para el control de Chrysomphalus dictyospermi y Aonidiella aurantii (Hom.: Diaspididae) en cítricos de la Comunidad Valenciana. Boletin Sanidad Vegetal Plagas 33:311-320.

Viggiani, G. 1988. Citrus pests in the Mediterranean basin. Pages 1067-1073. Proceedings of the 6th International Citrus Congress, Israel.

Viggiani, G. 1994. The Aphytis fauna of the West Palearctic region, with notes on their biological control. Pages 336-347 in D. Rosen, editor. Advances in the study of Aphytis (Hymenoptera: Aphelinidae). Intercept Limited, UK. 


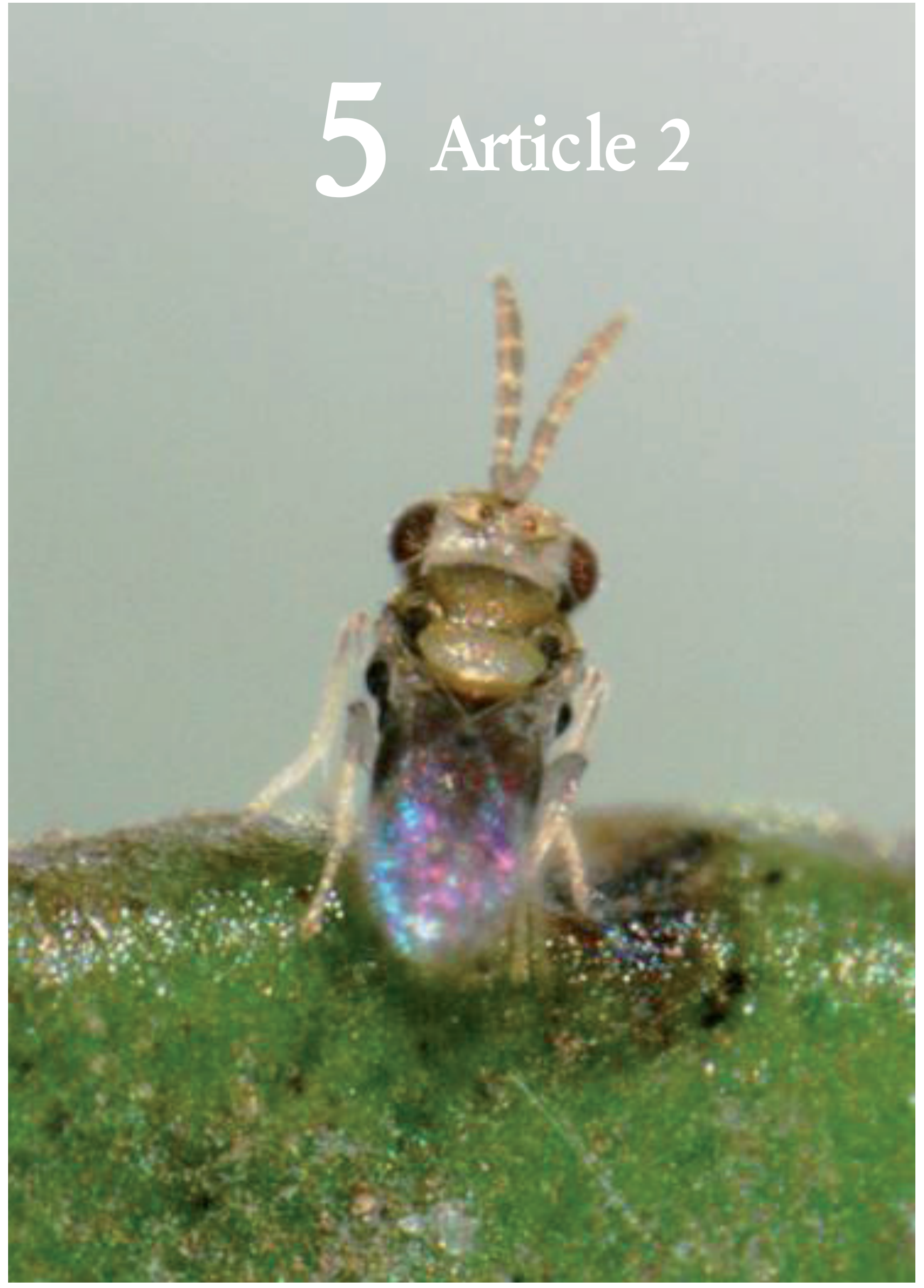





\title{
Comparative efficacy of different combinations of natural enemies for the biological control of California red scale in citrus groves*
}

\author{
Juan Sorribas and Ferran Garcia-Marí \\ Instituto Agroforestal Mediterráneo, Univ. Politécnica de Valencia, Camino de Vera s/n 46022 Valencia, Spain \\ * As published in Biological Control, 55, 2010, pp. $42-48$ (I.F.: 2.16)
}

Abstract. The California red scale (CRS), Aonidiella aurantii, a worldwide citrus pest, has the ectoparasitoid Aphytis melinus as its main natural control agent. Other natural enemies can complement $A$. melinus in the pest control. During three years we studied the incidence of the parasitoids and predators on CRS populations of 19 citrus groves divided in four groups according to its parasitoid composition to determine which combination of natural enemies reaches higher effectiveness in the biological control of CRS in field conditions. The parasitoids species preferred different scale instars and different periods of the year for parasitism. In the orchards where A. melinus was present in high numbers, either alone or coexisting with Aphytis chrysomphali, parasitism rates reached $22.4 \%$ on average, whereas parasitism rates were much lower (11.5\%) when A. chrysomphali was the dominant parasitoid. The best parasitism level was achieved when these ectoparasitoids occurred together with the endoparasitoid Encarsia perniciosi. The average annual mortality rate of $A$. aurantii was $73.6 \%$. The analysis of dead scales killed by Aphytis confirms the results obtained in parasitism of live scales. The more abundant predators were Lestodiplosis aonidiellae and Rhyzobius lophantae. The incidence of predators on the CRS populations was comparatively much lower.

Key words: Aonidiella aurantii; Aphytis melinus Aphytis chrysomphali; Encarsia perniciosi; parasitism; parasitoid coexistence; scale predators 


\section{1. Introduction}

The California red scale (CRS), Aonidiella aurantii (Maskell), one of the most important citrus pests worldwide, can be reduced to economically insignificant levels by the action of natural enemies (DeBach, 1969; Reeve and Murdoch, 1986; Foster and Luck, 1996). Successful control has been demonstrated in areas where several parasitoids combine to keep the pest at acceptable low level (Samways, 1994). It is also possible to maintain CRS populations at low stable densities by the combination of resource-specialist parasitoids and predators; the limitation of one organism is often compensated for by the strengths of another (DeBach et al., 1971; Foster et al., 1995).

Aphytis melinus (DeBach), an aphelinid ectoparasitoid, is considered the most successful and widespread biological control agent of CRS (DeBach and Rosen, 1991; Foster and Luck, 1996; Murdoch et al., 1989). Other Aphytis species, like Aphytis chrysomphali (Mercet), can be found in many countries in coexistence with A. melinus (Luck and Podoler, 1985; Dahms and Smith, 1994; De Santis and Crouzel, 1994; Asplanato and Garcia-Marí, 2002). Several endoparasitoids, like Encarsia (=Prospaltella) perniciosi (Tower), have also been described attacking CRS. The role of the endoparasitoids can be considered as complementary to Aphytis since they can attack other scales instars that ectoparasitoids are not able to parasitize (DeBach, 1969; Yu et al., 1990; DeBach \& Rosen, 1991; Rosen, 1994). Groves in which red scale is held at low levels by parasitoids usually show an average year round active parasitism of about 15-25\% (DeBach, 1969; Reeve and Murdoch, 1986).

Only those scale instars in which the body is detached from the cover are vulnerable to parasitism by Aphytis. These are second instar females, third instar virgin females and males second instar (Reeve and Murdoch, 1986; Foster and Luck, 1996). Aphytis also kill a substantial percentage of scales by host-feeding in which the female feeds from the scale body. Usually host-feeding produces a dark rusty brown mottled spot on the scale body (mutilation mark) which is caused by the ovipositor (Foster et al., 1995).

Encarsia perniciosi CRS strain can parasitize almost all host stages of the scale, but as its eggs and larvae are inside the scale body only Encarsia pupae can be seen with binocular (Yu et al., 1990; Foster and Luck, 1996). This endoparasitoid is 
always outcompeted by Aphytis when both species parasitize the same host (Yu et al., 1990; Borer et al., 2004). The seasonal evolution of captures in field traps was studied by Asplanato and Garcia-Marí (2002).

The most commonly described predators of CRS are Rhyzobius (=Lindorus) lophantae Blaisdell and Chilocorus bipustulatus (L.) (Coleoptera: Coccinellidae), Lestodiplosis aonidiellae Harris (Diptera: Cecidomyiidae), Chrysoperla carnea (Stephens) (Neuroptera: Chrysopidae) and the mites of the genus Hemisarcoptes Meyer (Astigmata: Hemisarcoptidae) (Meyer, 1962; DeBach, 1969; Ben-Dov and Rosen, 1969; Luck, 1995; Foster and Luck, 1996; Siscaro et al., 1999; Erler and Tunç, 2001; Urbaneja et al. 2005, etc.). Predators are effective biological control agents of CRS only on high prey densities and are usually not highly host-specific (Rosen, 1986; Siscaro et al., 1999).

In the Valencia Region (eastern Spain), the most extended citrus area in Europe, Aonidiella aurantii has expanded since 1986 to almost all the citrus orchards (Garcia-Marí et al., 1988, Alfaro et al., 1999; Moner, 2000). In the south of this region, like in many other citrus areas around the word, the superior competitor A. melinus has displaced previously existing CRS parasitoids (DeBach and Sundby, 1963; Luck and Podoler, 1985; Smith et al., 1997; Sorribas et al., 2010). However, A. chrysomphali coexists with $A$. melinus, in an increasing percentage from South to North, in other citrus areas of Valencia Region. Encarsia perniciosi is also present in a small semitropical area (Troncho et al., 1992; Rodrigo et al., 1996; Pina et al., 2003; Sorribas et al., 2008; Sorribas et al., 2010).

Much has been studied concerning CRS parasitoids and predators, most in laboratory assays, but there are no studies about field comparative efficacy of different combinations of natural enemies on controlling this pest. We wanted to answer these questions: Which combination of natural enemies achieves better CRS control? Is it higher the parasitism level on A. aurantii in areas where one or more parasitoids coexist with $A$. melinus than in the areas where this species is present alone? To solve these questions we have studied and compared the parasitism levels through the year in areas with different parasitoid species or with the same parasitoids present in different proportions. We examined how the preference for a different tree substrate or for a different CRS instar allows the coexistence of parasitoid species. Finally, we analyzed how abundant are the CRS predators in 
Mediterranean conditions in relation to parasitoids and their incidence on the scale populations.

\title{
5.2. Materials and methods
}

\author{
Study area
}

The study was conducted in citrus groves of Valencia Community, eastern Spain, during the years 2006-2008. We collected samples of twigs and fruits (when present in the field) from 19 sweet orange (Citrus sinensis [L.] Osbeck) groves infested with $A$. aurantii. Each grove was sampled four times on average (with a minimum of three and a maximum of six) along the 3-year period. On each grove, the sampling dates were distributed along the year trying to cover the four seasons. In three of the groves the spring period could not be sampled due to the low CRS population present.

Samples were randomly collected from at least five different scale-infested trees of the grove. The twigs, on which leaves were eliminated, were $0.5-1.5$ years old and about $30 \mathrm{~cm}$ long. Samples of fruits were collected when $>3 \mathrm{~cm}$ in diameter. On each sample an average of 30 twigs and 25 fruits were observed.

The groves were distributed all over the citrus-growing area of Valencia Community, an almost continuous citrus belt of $400 \mathrm{~km}$ long from north to south and $50 \mathrm{~km}$ wide. All the groves selected were commercial citrus plantations grown under IPM practices. Usually the groves were sprayed once or two times a year. Sprays were applied in spring, usually with pyriproxyfen, and/or in summer with mineral oil.

\section{Laboratory analysis}

In the laboratory, samples were separated in two groups, twigs and fruits, which were analyzed separately under a stereoscopic microscope to determine the percentage of live scales in various instars as well as the percentage of parasitism. The cover of the scales was lifted up with a needle and live, dead and parasitized forms of the scale were recorded until 50 non-parasitized live forms of each scale 
stage susceptible to be parasitized by Aphytis were counted per group. Thus, in the groves where only Aphytis parasitoids were present, we counted 150 live red scales (50 second instars, 50 males and 50 virgin females) plus the parasitized scales. The development stage of each immature Aphytis (egg, larva, prepupae and pupae) was recorded. In the groves where E. perniciosi was present, all the scale forms in which this endoparasitoid was detectable with binocular were counted. This included 50 live forms of male instars, second instar females, second molt, third instar virgin females and gravid female scales. During the collection of samples in the field and during the analysis for parasitism all predators found either preying on the CRS colony (adult and larval forms) or below the scale cover were identified and recorded. Thus, each scale was scored as live, parasitized by Aphytis or Encarsia, mutilated by Aphytis, preyed upon (if clearly chewed or any predator was present) or dead.

In order to know the proportion of the different parasitoid species present in each grove, part of the samples of twigs and fruits (around 20-30 fruits depending on size and about 40 twigs) were reserved and kept in rearing cages to obtain emerging adult parasitoids. Rearing cages consisted of $40 \times 30 \times 22 \mathrm{~cm}$ transparent plastic boxes covered with a gauze and maintained inside climatic chambers (26$28^{\circ} \mathrm{C}, 60 \%$ relative humidity, $16: 8 \mathrm{hr}$ photoperiod) for 20 days to allow all parasitoids develop to adults (A. melinus needs about 18 days from egg to adult at $26^{\circ} \mathrm{C}$ ). Adult parasitoids were captured on yellow $12 \times 12 \mathrm{~cm}$ sticky traps placed inside the cages or collected dead from the bottom of the cage.

Based on pupae of parasitoids found under scale covers and adults captured in rearing cages we determined the dominant parasitoid species for each grove. With these data we grouped the groves into four groups (Fig. 1):

Groves with no E. perniciosi present:

- Group 1. Groves with $>80 \%$ of $A$. chrysomphali: four groves at the north of the Valencia Community.

- Group 2. Groves with both Aphytis species together in similar proportion: eight groves at the centre of the Valencia Community.

- Group 3. Groves with $>80 \%$ of $A$. melinus: four groves in inland and south areas of the Valencia Community. 


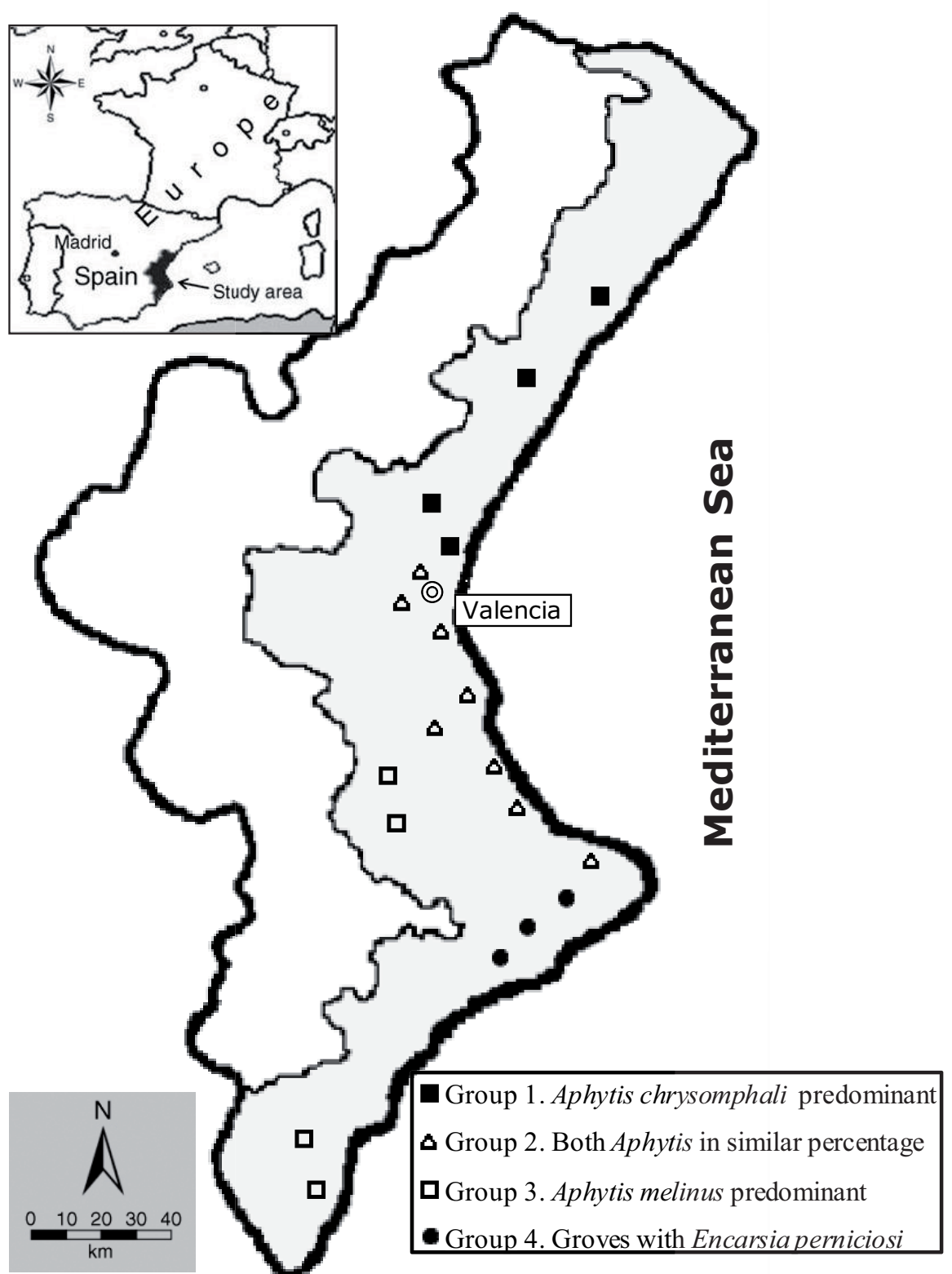

Fig. 1. Distribution of the groves of study in the Valencia Community (esatern Spain) citrus area (shaded area) and groups of groves in which they were divided for the comparison of parasitism on California red scale. The sampling period was 2006-2008. 
Groves with E. perniciosi present:

- Group 4. Three groves situated in a coastal humid area. These groves contained also the ectoparasitoids A. melinus and $A$. chrysomphali.

We compared the parasitism levels between the two species of Aphytis in the groups 1, 2 and 3. This comparison was made in the CRS stages susceptible to parasitism by these ectoparasitoids. In order to compare homogenous groups of stages, the comparison of groves with and without E. perniciosi was made in the three same CRS stages, male instars, second instar females and third instar virgin females although this means that some CRS stages susceptible to E. perniciosi were not considered.

\section{Data Analysis}

Average values and seasonal variations have been expressed globally for the 3 -year period of the study as results were rather similar and consistent over the years. The average active parasitism by Aphytis spp. was estimated through the observation of live non-parasitized and parasitized CRS in the three stages susceptible to parasitism by Aphytis. The percentage of parasitism attributable to each of the Aphytis species was evaluated through the pupae of the parasitoids observed. Host feeding was evaluated through the observation of mutilation marks on the scale body. The average parasitism by E. perniciosi was estimated on the susceptible CRS stages in which immature parasitoids were detectable with binocular. We estimated the mortality of the CRS population (as percent of dead insects) from the observation of live and dead scales on twigs and fruits. Among dead scales of $A$. aurantii observed, those killed by Aphytis parasitoids, evaluated through the observation of any Aphytis remnant (meconial pellets, exit holes, pupal cases and dead parasitoids) were recorded separately to estimate the mortality due to these parasitoids. Similarly, the percentage of scales killed by E. perniciosi was evaluated through the observation of exit holes, the CRS residual ectoderm and dead parasitoids. The predatory incidence was estimated as the number of live CRS with a predator present or with predatory chewing symptoms.

All statistical analyses were performed utilizing Statgraphics 5.1 program (Statgraphics 2000). Differences in the percentage of parasitism between the three 
scale instars vulnerable to parasitism by Aphytis and differences between parasitism on fruits and twigs by Aphytis and E. perniciosi were analyzed using one-way analysis of variance (ANOVA). The analysis of parasitism per scale stage by each of the Aphytis species and the comparison between the groups of groves, both with and without $E$. perniciosi were performed by one-way ANOVA. The mortality among these groups of groves was also compared by one-way ANOVA. Differences in scale mortality between twigs and fruits, differences in the average Aphytis-induced mortality between scale instars and between fruits and twigs and differences in the mortality of Aphytis in fruits and twigs were performed by one-way ANOVA.

Means were compared using Fisher's LSD test. Data on the percentages were arcsine square-root transformed before ANOVA to stabilize the variance.

\subsection{Results}

\section{Parasitism by Aphytis species}

Overall, the average annual parasitism rate by Aphytis species was $17.1 \%$. Maximum parasitism levels reached up to $64 \%$ of the susceptible stages in some samples. Higher levels of parasitism were found between August and November (highest in September) and lower in February and March (Fig. 2). Virgin females were much preferred by Aphytis (average parasitization of $29.2 \pm 4.7 \%$ ) than second instars $(14.2 \pm 3.3 \%)$ and males $(9.3 \pm 2.2 \%)\left(F_{2,285}=33.30 P<0.0001\right)$. Scales on fruits were more preferred for parasitism by Aphytis than those on twigs $(20.6 \pm 2.9 \%$ and $13.7 \pm 2.0 \%$ of parasitism respectively $\left(F_{1,286}=10.27 P<0.01\right)$.

The analysis of parasitism by each of the Aphytis species showed that $A$. melinus prefers virgin females instars to males and second instar females of CRS for parasitism $(67.3 \pm 3.8 \%, 19.8 \pm 3.5 \%$ and $14.9 \pm 1.8 \%$, respectively $)\left(F_{2,329}=24.15\right.$ $P<0.0001$ ), whereas $A$. chrysomphali prefers second instar stages followed by virgin females and males $\left(45.1 \pm 4.0 \%, 35.6 \pm 3.5 \%\right.$ and $20.2 \pm 3.2 \%$, respectively) $\left(F_{2,329}=\right.$ $5.55 P=0.004)$. 


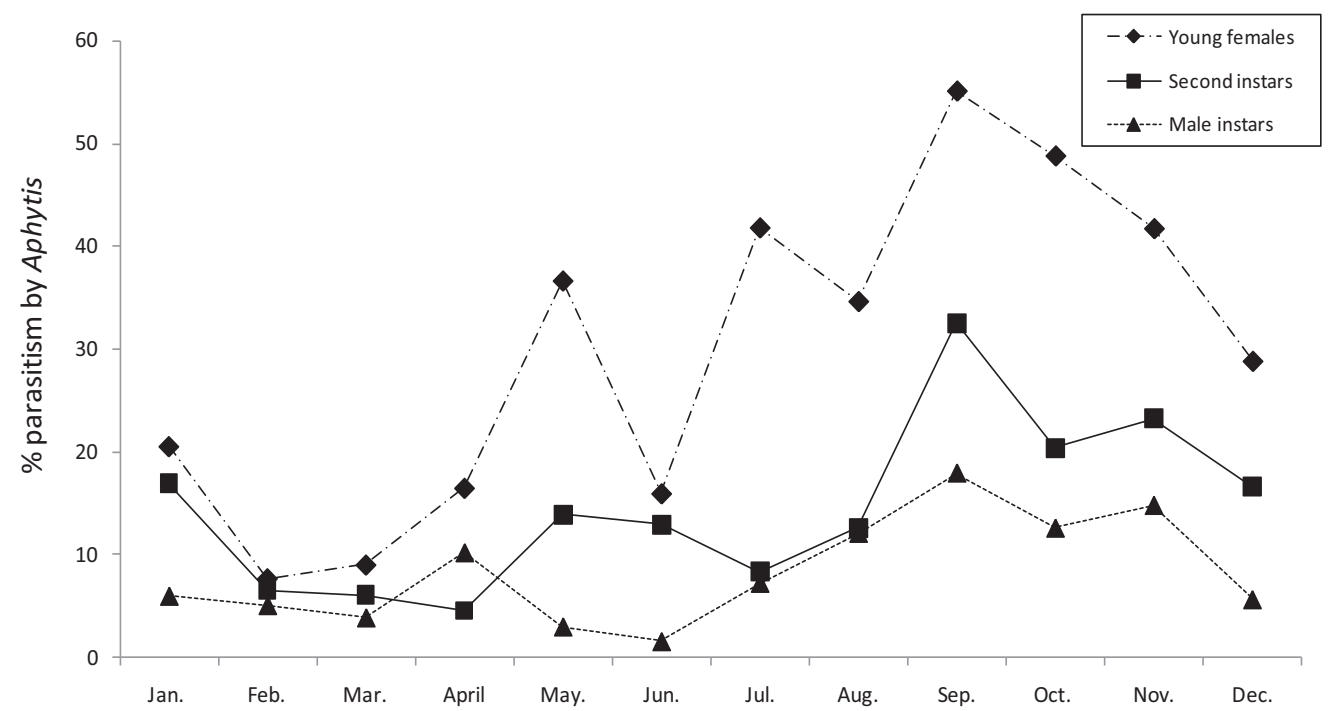

Fig. 2. Seasonal variation of the percentage of parasitism by Aphytis spp. (A. melinus and $A$. chrysomphali) in the three California red scale stages susceptible to parasitism. Monthly average parasitism from samples of fruits and twigs in 19 citrus groves of the Valencia Community (eastern Spain). The sampling period was 2006-2008.

Multiple parasitism cases were only found in virgin female host scales. From the total CRS scales parasitized by Aphytis, 6.9\% $(\mathrm{n}=179)$ included two or more parasitoids (from egg to pupae stages). Through the observation of pupae, most multiple parasitism cases ( $86 \%$ of the total) were A. melinus.

Host feeding represented $2.1 \%(\mathrm{n}=250)$ of the live scales, most of them found on virgin female stages. This host feeding was probably underestimated since when Aphytis feeds on the scale it rapidly dies and the effect of host feeding is not always evident.

\section{Parasitism by Encarsia}

Encarsia perniciosi was present in three groves, all belonging to a coastal humid area. All samples in which E. perniciosi was present also contained $A$. melinus and A. chrysomphali in higher amount than the endoparasitoid. 
Among live scales, the annual average parasitism rate by E. perniciosi was $12.3 \%$. Real parasitism was probably higher since eggs and larvae of E. perniciosi can't be detected with binocular. The highest rates of parasitism were observed during spring and reached up to $21 \%$ (Fig. 3). A higher average parasitism rate was observed on twigs $(14.3 \pm 2.9 \%)$ than on fruits $(10.0 \pm 5.1 \%)$, although difference between both substrates was not statistically significant $\left(F_{1,49}=1.44 P=0,23\right)$.

Among dead scales of A. aurantii those killed by E. perniciosi were on average $8.2 \%$ of all the scales observed. This proportion was an underestimation of the mortality caused by Encarsia since early mortality of the endoparasitoid before reaching the pupal stage was not included.

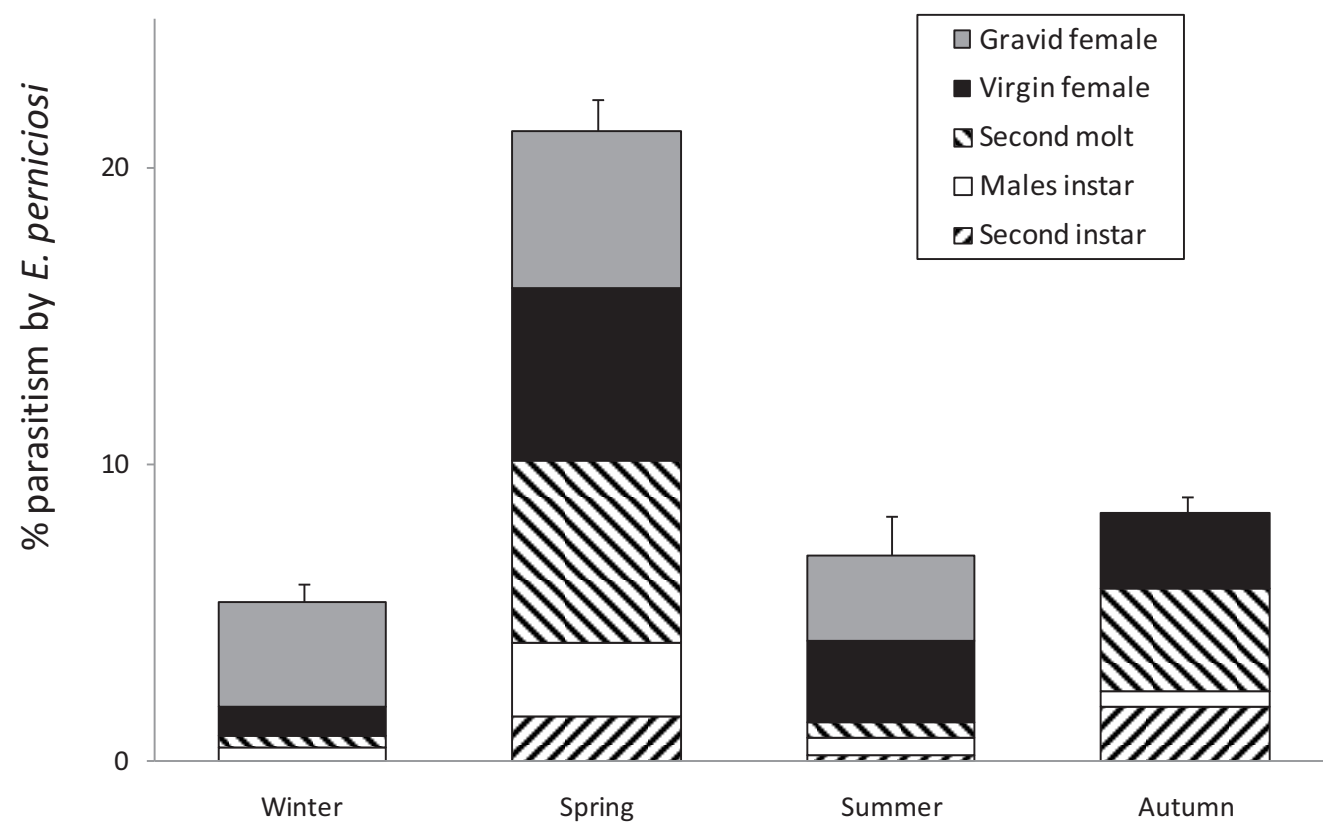

Fig. 3. Seasonal variation of the percentage of parasitism by Encarsia perniciosi in the California red scales stages in which parasitism was detectable with binocular. Average parasitism from samples of fruits and twigs in three citrus groves of the Valencia Community (eastern Spain). The sampling period was $2006-2008$. 


\section{Comparative levels of parasitism}

From the comparison of parasitism on live scales between the groups of groves with different proportions of parasitoids, we obtained significantly lower parasitism levels when A. chrysomphali was in higher proportion than A. melinus $(11.5 \% \pm 1.2 \%)$, but there was no difference between groves where A. melinus was alone $(21.9 \pm 2.2 \%)$ or in coexistence with $A$. chrysomphali $(20.7 \pm 2.0 \%)$ $\left(F_{2,288}=12.97 \quad P<0,0001\right)$. The groves where E. perniciosi was present showed significantly higher parasitism $(24.8 \pm 2.8 \%)$ than groves without E. perniciosi $\left(F_{3,291}=8.53 P<0,0001\right)$.

Similarly, when we compared the global mortality on CRS population in the three groups of groves with different proportions of Aphytis and without E. perniciosi, we obtained significantly lower mortality in the group of groves where $A$. chrysomphali was in higher proportion than A. melinus $(70.6 \% \pm 1.4 \%)$, compared with the group of groves with $A$. melinus alone $(76.2 \% \pm 1.9 \%)$ or in coexistence with A. chrysomphali $(74.8 \% \pm 2.0 \%)\left(F_{2,329}=12.97 \quad P<0,0001\right)$. The area where $E$. perniciosi was present showed significantly higher mortality on CRS population $(80.9 \% \pm 3.1 \%)$ than the other three groups $\left(F_{3,329}=13.12 P<0,0001\right)$.

\section{Aonidiella aurantii and Aphytis mortality}

The mortality of Aonidiella aurantii, estimated as percent of dead scales, was very high all year round. It reached an annual average of $73.6 \%$. Mortality was highest in May (89.2\%) and lowest in August (65.1\%) (Fig. 4). There were no statistical differences in mortality between the three scale stages evaluated, virgin females, male instars and second instars $\left(F_{2,329}=1,36 P=0,26\right)$. The scale mortality was significantly higher on twigs $(78.7 \pm 0.7 \%)$ than on fruits $(61.8 \pm 0.4 \%)$ $\left(F_{1,329}=76,42 P<0,0001\right)$.

Among dead scales of A. aurantii observed, those killed by Aphytis parasitoids, were $14.0 \%$ on average. This proportion was underestimated since mortalities caused by host feeding or Aphytis which died in larval forms were not evaluated. Average Aphytis-induced mortality on virgin female instars was significantly higher $(23.5 \pm 2.0 \%)$ than in second instars $(10.6 \pm 0.9 \%)$ and males $(5.9 \% \pm 1.1 \%)\left(F_{2,329}=98.4 P<0.0001\right)$ (Fig. 4). Likewise, it was significantly higher on fruits $(18.3 \pm 0.5 \%)$ than on twigs $(10.5 \pm 0.4 \%)\left(F_{1,329}=36.23 P<0.0001\right)$. 


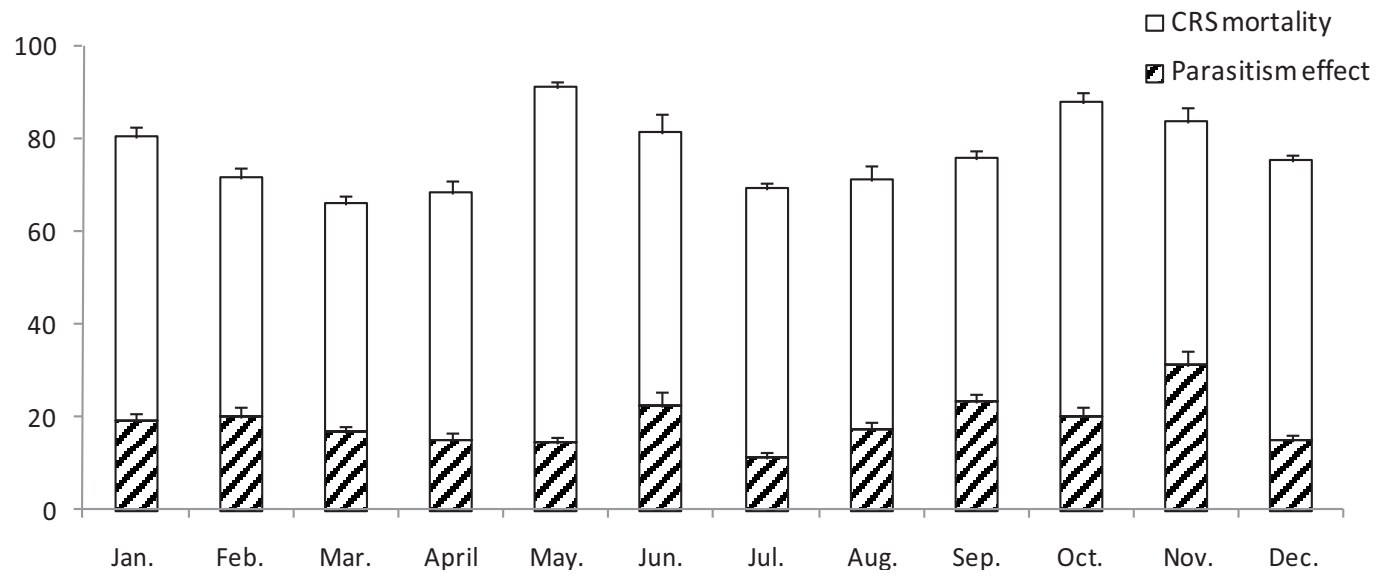

Fig. 4. Seasonal variation of the percentage of mortality of California red scale and proportion of it due to Aphytis species (evaluated through the observation of meconial pellets, exit holes, pupal cases or dead parasitoids). Monthly average $( \pm \mathrm{SE})$ of dead scales from samples of fruits and twigs in 19 citrus groves of the Valencia Community (Eastern Spain). The sampling period was 2006 2008.

We observed a considerable number of dead pupae of Aphytis under the CRS covers, some of them partially predated. Overall, 305 cases were recorded. This represented 13.3\% $(\mathrm{n}=2291)$ of the total number of scales with Aphytis remnants observed. This ratio was significantly higher in twigs compared with fruits (17.1 $\pm 0.1 \%$ and $11.2 \pm 0.1 \%$, respectively; $F_{1,262}=20.22 P<0.0001$ ).

\section{Predators. Relative abundance and biological notes}

The total number of predators observed was much lower than the number of parasitoids (296 predators vs. 2978 parasitoids), representing $9.0 \%$ of the natural enemies identified. The predatory incidence, an approximate index of the activity of the predators, was estimated as $1.7 \%$ of the total live scales. The samples of twigs contained a higher incidence of predators than the samples of fruits $(1.9 \%$ and $1.5 \%$ respectively). There were no differences in the distribution of the main predators in the study area. The most abundant predators were Lestodiplosis aonidiellae and Rhyzobius lophantae (Table 1). 
Table 1. Species and amount of predators (adult and larval forms) found either preying on the California red scale colony or below the scale cover during the collection of samples in the field and during the analysis for parasitism. Samples were collected from 19 citrus groves of the Valencia Community (eastern Spain) during the period 2006 -2008.

\begin{tabular}{lc}
\hline \multicolumn{1}{c}{ PREDATOR } & NUMBER \\
\hline Lestodiplosis aonidiellae Harris & 123 \\
Rhyzobius lophantae Blaisdell & 109 \\
Semidalis aleyrodiformis Stephens & 24 \\
Chrysoperla carnea (Stephens) & 17 \\
Chilocorus bipustulatus (L.) & 14 \\
Hemisarcoptes spp. Meyer & 9 \\
\hline
\end{tabular}

Larval forms of $L$. aonidiellae were often found to feed beneath the scale body of big scales either young or mature females instar (Aphytis larvae were also observed in its diet). It was also common under the calyx of citrus fruits. Both adult and immature forms of the coccinellids $R$. lophantae and $C$. bipustulatus were observed to prey actively on almost all scale instars. They were able to break the scale cover with the mandibles and feed on the scale body, leaving characteristic irregular holes on the cover. Larvae of $R$. lophantae very often took refuge under the calyx of the fruits and were also observed preying on Aphytis pupae (sometimes eating only the head). Chilocorus bipustulatus presented strong seasonality, being mainly found during summer and early autumn.

Several adult and larval forms of Semidalis aleyrodiformis (Neuroptera: Coniopterygidae) were found while preying white cap and virgin female scale stages (lifting the scale cover). Solitary eggs and the characteristic white silk circular cocoons of this species were found in the proximity of the scale colonies. Captures of this predator were more abundant on twigs than on fruits and concentrated mainly in September. Larvae of another Neuroptera, C. carnea, were found while preying on crawlers of the red scale and they were also capable to feed on virgin female stages. Eggs of this species were often found in the proximity of the scale colony. 
The mite $H$. coccophagus was found preying on the body of virgin female instars. Several adults and eggs (about 10-15 eggs) were observed together in small colonies under one virgin female scale.

\subsection{Discussion}

The analysis of the scale instars parasitized by the two Aphytis species shows that $A$. melinus clearly prefers virgin females for parasitism while the smaller $A$. chrysomphali prefers second instar females. Previous studies showed that A. melinus prefers scales larger than $0.39 \mathrm{~mm}^{2}$ whereas A. chrysomphali parasitized mostly scales lower than $0.33 \mathrm{~mm}^{2}$ (Luck and Podoler, 1985; Foster et al., 1995; Morgan and Hare, 1998; Pina et al., 2003; Pekas et al., 2008). Thus, since both parasitoid species are not strict ecological homologues coexistence is possible if weather conditions are appropriated (groves in groups one, two and four of our study). Indeed, in coastal citrus areas where high relative humidity and mild summer temperatures allow A. chrysomphali survival it can compete with A. melinus due to its younger host preference. When a new generation of CRS starts in spring, $A$. chrysomphali will have a competitive advantage since its feeding resource is available earlier than for A. melinus. This lead time allows $A$. chrysomphali to emerge earlier in the year and to build up sufficient densities such that the superior competitor A. melinus cannot exclude it (coexistence due to temporal niche partitioning). But in the group four, which includes groves in inland and south citrus areas, the dry and hot summers allow only the existence of the A. melinus which, being original from India (Rosen and DeBach, 1979), is better adapted to these conditions.

The importance of E. perniciosi was relatively high, averaging $12.3 \%$ of parasitism in the orchards where it was established. This value must be increased if we consider that many of these endoparasitoids are consumed in larval forms by $A$. melinus as readily as unparasitized scales (Yu et al., 1990; Borer et al., 2004) and young larval stages of E. perniciosi were not considered. In our study, as it was previously described (Murdoch et al., 1989; Yu et al., 1990), Encarsia, in contrast with Aphytis, shows similar or a bit higher preference for scales on twigs than for scales on fruits. Also, the parasitism produced by E. perniciosi was higher during spring, a period when, as explained before, parasitism by Aphytis was much reduced. 
The intense reduction in E. perniciosi presence during summer and autumn could be due, at least in part, to the predation by Aphytis larvae that are more abundant in these periods of the year. Thus, E. perniciosi perfectly complements Aphytis species not only because of its higher number of parasitizable scale instars and its higher preference for the scales on twigs, also because their peaks of abundance appear in different period of the year. Anyway, Aphytis presents two competitive advantages in relation to Encarsia, its multiple parasitism capacity, which represents an increase in progeny generated per female, and the host feeding capacity, which allows Aphytis to survive when no other food is available. These advantages allow $A$. melinus a better reproduction rate when the new generation starts in late spring. Multiple parasitism in virgin female instars, mainly by A. melinus, represented in our study $7 \%$ of the total CRS parasitized, and host feeding $2 \%$ of the total live scales counted.

The global average parasitism by Aphytis species obtained (17.1\%) reaches the optimal percentage range $15-25 \%$ indicated by several authors to keep CRS under control (DeBach, 1969; Reeve and Murdoch, 1986). This parasitism was higher (average 22.4\%) in the orchards where Aphytis melinus was abundant (groups 2, 3 and 4). Thus, the only reason that could explain why in many citrus areas of Valencia Community A. aurantii still reaches high levels is the inappropriate use of pesticides that eliminates the parasitoids. Parasitoids had much more importance in the biological control of CRS than predators, which represented only $9 \%$ of the total natural enemies found. On the other hand, in all citrus groves analyzed the parasitism increased from the low levels reached in February and March to the maximum levels reached in September. Probably, cold winter temperatures cause high mortality on Aphytis population and thus the first generation of CRS grows without parasitoid control. Therefore, this first generation could be an appropriate moment if releases of natural enemies are necessary to complement biological control.

When we compared parasitism levels, the groves where A. chrysomphali was predominant showed lower proportion of scales parasitized than the groves where $A$. melinus was more abundant, or where both parasitoids coexisted in similar levels. This confirms that A. melinus is superior parasitoid on controlling CRS population. In fact, the higher parasitism rate reached by A. melinus could explain why in California, as it was described by DeBach and Rosen (1991), when A. chrysomphali was the only parasitoid present the CRS reached high infestation levels and later on, 
after the introduction and establishment of $A$. melinus, the pest was reduced to non damage levels. The highest average parasitism was reached in the groves where the third parasitoid, E. perniciosi, was present (24.8\%), although several scale instars parasitizable by this endoparasitoid were not included. Thus, the combination of the ectoparasitoids Aphytis with the endoparasitoid E. perniciosi increases the global parasitism level of the CRS.

Through the observation of dead scales and the presence of parasitoid remnants it was possible to arrive to the same conclusion in relation with the impact of parasitism in CRS population. The overall percentage of dead scales with parasitoid remnants was similar to the percentage parasitism obtained on live scales, either considering the parasitism globally $(14.0 \%)$ or separately on each substrate and on each susceptible stage of CRS. The slight reduction is probably due to the fact that not all parasitoids complete development to adult, dying in larval and pupal forms, and thus they leave no meconial remnants under the scale. This is confirmed by the considerable number of dead pupae of Aphytis found (305 pupae). The mortality of the CRS was very high all year around, but it was significantly higher in twigs, probably because they represent a poorer quality food supply and produce a higher proportion of undersized scales for parasitism. This means that parasitoids need to check for more scales with their antenna to find an adequate host and, when parasitized, the host could be not big enough to allow complete development of the parasitoid (this can explain the significantly higher ratio of dead Aphytis found on twigs).

Summarizing, A. melinus has clearly higher impact on the CRS population than other parasitoid species and predators. In the orchards where this parasitoid is present, either alone or coexisting with $A$. chrysomphali, parasitism rates reach $22.4 \%$ on average, whereas in the orchards were this parasitoid is not present, or present in low proportion, the parasitism rates are much lower (11.5\%). The effect of A. chrysomphali on CRS population can be complementary to that of A. melinus as they choose different scale instars for parasitism. Field parasitism of Encarsia perniciosi was relatively high, mainly during spring when Aphytis parasitism was lower, thus they complement each other in the biological control of CRS along the year. The combination of ectoparasitoid and endoparasitoid species, especially when they are able to parasitize different scale instars and/or prefer different three substrates, can increase the total parasitism level and thus the biological control of 
this pest, as shown by the higher parasitism levels reached in the groves where $E$. perniciosi was present.

\section{Ackowledgements}

The authors wish to thank Eugenia Rodrigo of the Ecosistemas Agroforestales Department of the Valencia Polytechnic University (Spain) for her help with Aphytis identification, Marcela Skuhravá (Czech Zoological Society) and Alberto Urbaneja (Instituto Valenciano de Investigaciones Agrarias, Spain) for the information related with predators, Ana Alemany (Universitat Illes Baleares, Spain) for the critical review and the Citrus Phytosanitary Survey staff (Agriculture Departement of the Valencia Community Government) for the field trap samples. This work was supported by the AGL2005-07155-C03-03 project of the Spanish Ministry of Education and Science.

\subsection{Literature cited}

Alfaro, F., Cuenca, F., Esquiva, M., 1999. Problemática actual del piojo rojo de California en la C. Valenciana. Comunitat valenciana agraria 95, 54-60.

Asplanato, G., Garcia-Marí, F., 2002. Parasitismo de la cochinilla roja californiana Aonidiella aurantii en la zona citrícola sur de Uruguay. Boletín Sanidad Vegetal de Plagas 28, 5-20.

Ben-Dov, Y., Rosen, D., 1969. Efficacy of Natural enemies of the California red scale on citrus in Israel. Journal of Economic Entomology 62 (5), 1057-1060

Borer, E. T., Murdoch, W. W., Swarbrick, S. L., 2004. Parasitoid coexistence: linking spatial field patterns with mechanism. Ecology 85, 667-678.

Dahms, E.C., Smith, D., 1994. The Aphytis fauna of Australia. In D. Rosen (Ed.) Advances in the study of Aphytis. Intercept Limited, UK, pp 245-255.

De Santis, L. Crouzel, I. S., 1994. Species of Aphytis occurring in the Neotropical region and their role in biological control. In D. Rosen (Ed.). Advances in the study of Aphytis. Intercept Limited, UK, pp 256-277. 
DeBach, P., 1969. Biological control of Diaspine scale insects on citrus in California. Proceedings of the 1st International Citrus Symposium, 801-815.

DeBach, P., Rosen, D. Kennett, C.E., 1971. Biological control of coccids by introduced natural enemies. In C. Huffaker (Ed.). Biological control. Plenum, New York, USA, pp 165-194.

DeBach, P., Sundby, A., 1963. Competitive displacement between ecological homologues. Hilgardia 34, 105-166.

DeBach, P., Rosen, D., 1991. Biological control by natural enemies, $2^{\text {nd }}$ edition. Cambridge University press, Cambridge, UK.

Erler, F., Tunç, I., 2001. A survey (1992-1996) of natural enemies of Diaspididae species in Antalya, Turkey. Phytoparasitica 29 (4), 299-305.

Foster, L.D., Luck, R.F., 1996. The role of Natural Enemies of California Red Scale in an IPM Program in California Citrus. Proceedings of the International Society of Citriculture, Sun City, South Africa, pp. 504-507.

Forster, L. D., Luck, R. F., Grafton-Cardwell, E. E., 1995. Life stages of California red scale and its parasitoids. University of California. Division of Agriculture and Natural Resources. Publication no 21529.

Garcia-Marí, F., Ribes, A., Costa-Comelles, J., Ferragut, F., 1988. Detección, muestreo y control de poblaciones del piojo rojo de California Aonidiella aurantii. Reunión Gr. Trabajo Cítricos. Servicio Protección Vegetal. in $\mathrm{M}^{\mathrm{o}}$ de Agricultura, editor. Reuniones anuales de los grupos de trabajo fitosanitarios. Madrid, Spain. pp 9-15.

Luck, R.F., 1995. California red scale. In J.R. Nechols (Ed.). Biological control in the Western United States. Division of Agriculture and Natural Resources, University of California. Publication 3361, Oakland, California, USA, pp 155-157.

Luck, R.F., Podoler, H., 1985. Competitive exclusion of Aphytis lingnanensis by A. melinus: Potential role of host size. Ecology 66, 904-913.

Meyer, M. K. P., 1962. Two new mite predators of red scale (Aonidiella aurantii) in South Africa. South African Journal of Agricultural Science 3, 411-418. 
Moner, J. P., 2000. Consideraciones sobre el control del piojo rojo de California, Aonidiella aurantii (Maskell). Comunitat Valenciana Agraria 16, 16-19.

Morgan, D.J.W., Hare, J.D., 1998. Innate and learned cues: scale cover selection by Aphytis melinus (Hymenoptera: Aphelinidae). Journal of Insect Behavior 11, 463-479.

Murdoch, W. W., Luck, R. F., Walde, S. J., Reeve, J. D., Yu, D. S., 1989. A refuge for red scale under control by Aphytis: Structural aspects. Ecology 70, 1707-1714.

Pina, T., Martínez, B., Verdú, M.J., 2003. Field parasitoids of Aonidiella aurantii (Hem.: Diaspididae) in Valencia (Spain). OILB/WPRS Bulletin 26, 91-96.

Pekas, A., Aguilar, A., Garcia-Marí, F., 2008. Host size availability for Aphytis parasitoids in field populations of California red scale Aonidiella aurantii, in Eastern Spain citrus groves. OILB/WPRS Bulletin 38, 34-40.

Reeve, J. D., Murdoch, W. W., 1986. Biological control by the parasitioid Aphytis melinus and population stability of the California red scale. Journal of Animal Ecology 55, 1069-1082.

Rodrigo, E., Troncho, P., Garcia-Marí, F., 1996. Parasitoids of three scale insects (Hom.: Diaspididae) in a citrus grove in Valencia, Spain. Entomophaga 41, 77-94.

Rosen, D., 1986. Natural enemies of the Diaspididae and their utilization in biological control. Bolletino del Laboratorio di Entomologia Agraria "Filippo Silvestri” 43, 189194.

Rosen, D., DeBach, P., 1979. Species of Aphytis of the World (Hym.: Aphelinidae). Dr. W. Junk Publishers, The Hague, Holland.

Rosen, D., 1994. Advances in the study of Aphytis (Hymenoptera: Aphelinidae). Intercept Limited, Andover, UK.

Samways, M. J., 1994. Insect conservation biology. Chapman and Hall, London, UK.

Siscaro, G., Longo, S., Lizzio, S., 1999. Ruolo degli entomofagi di Aonidiella aurantii (Maskell) in agrumeti siciliani. Phytophaga 9, 41-52. 
Smith, D., Beattie, G.A.C., Broadley, R., 1997. Citrus pests and their natural enemies: Integrated pest management in Australia. Dept. of Primary Industries. Queensland, Australia.

Statgraphics., 2000. Statgraphics Plus for Windows, version 5.1. Statistical Graphics Corp., Rockville, MD, USA.

Sorribas, J., Rodriguez, R., Rodrigo, E., Garcia-Marí, F., 2008. Niveles de parasitismo y especies de parasitoides del piojo rojo de California Aonidiella aurantii (Hemiptera: Diaspididae) en cítricos de la Comunidad Valenciana. Boletín Sanidad Vegetal de Plagas, 34, 201-210.

Sorribas, J., Rodriguez, R., Garcia-Marí, F., 2010. Parasitoid competitive displacement and coexistence in citrus agroecosystems: linking species distribution with climate. Ecological Applications (in press).

Troncho, P., Rodrigo, E., Garcia-Marí, F., 1992. Observaciones sobre el parasitismo en los diaspinos Aonidiella aurantii (Maskell), Lepidosaphes beckii (Newman) y Paralatoria pergandei (Comstock) en una parcela de naranjo. Boletín Sanidad Vegetal de Plagas 18, 11-30.

Urbaneja, A., Ripollés, J. L., Abad, R., Calvo, J., Vanaclocha, P., Tortosa, D., Jacas, J. A., Castañera, P., 2005. Importancia de los artrópodos depredadores de insectos y ácaros en España. Boletín de Sanidad Vegetal Plagas, 31, 209-223.

Yu, D. S., Luck, R. F., Murdoch., W. W., 1990. Competition, resource partitioning and coexistence of an endoparasitoid Encarsia perniciosi and ectoparasitoid Aphytis melinus of the California red scale. Ecol. Entomol. 15, 469-480. 


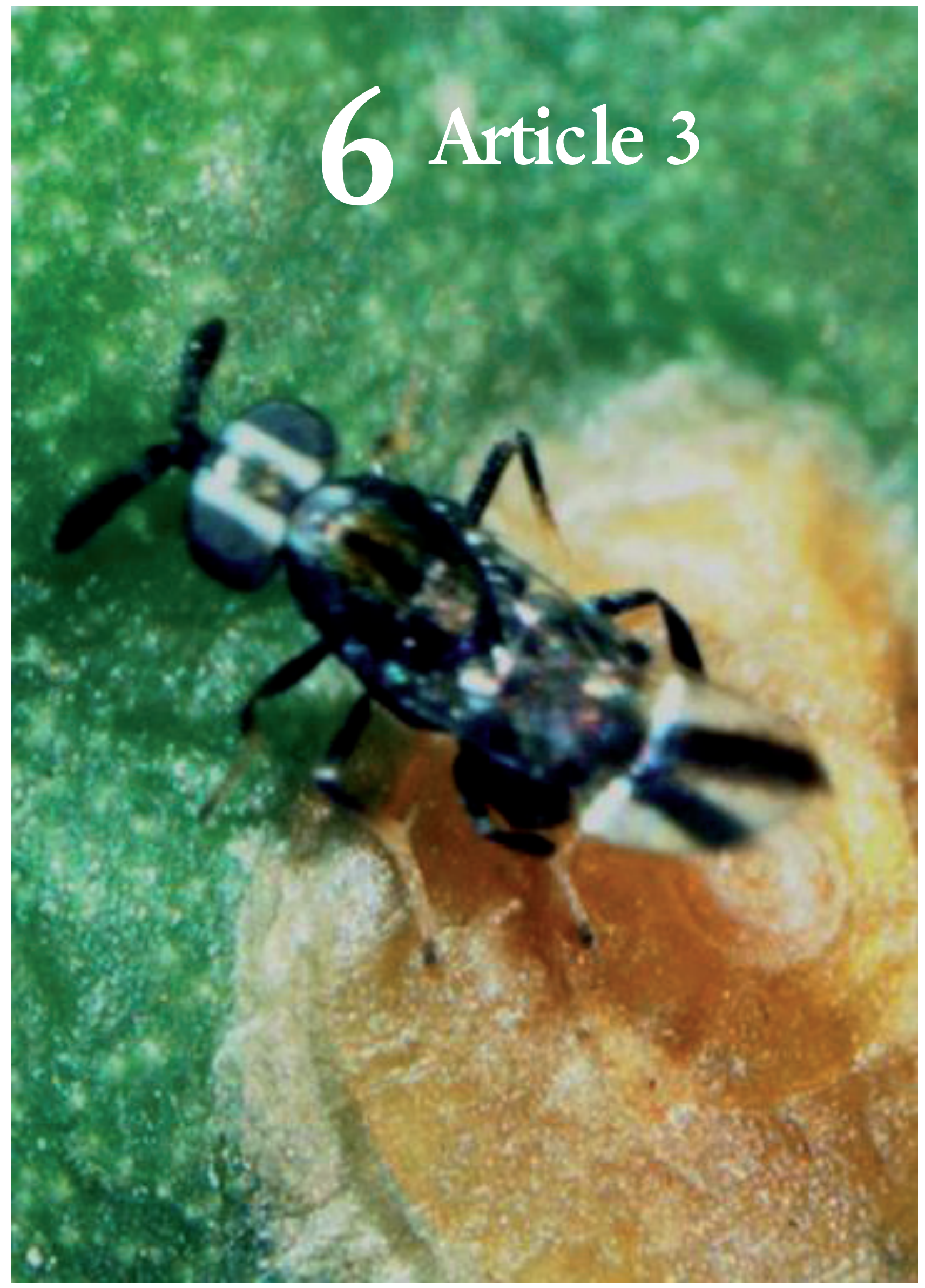





\title{
Effects of climate on the introduction, distribution and biotic potential of parasitoids: Applications to biological control of California red scale*
}

\author{
Juan Sorribas $^{1,2 *}$, Joan van Baaren ${ }^{2}$, Ferran Garcia-Marí ${ }^{1}$ \\ ${ }^{1}$ Instituto Agroforestal Mediterráneo, Univ. Politécnica de Valencia, Camino de Vera s/n 46022 Valencia, Spain \\ ${ }^{2}$ UMR- CNRS 6553 ECOBIO, Université de Rennes 1, Rennes, France
}

* As submitted to Biological Control, 2011.

Abstract. California red scale (CRS) parasitoids of 121 citrus groves belonging to three different Mediterranean-climate ecosystems (inland, coastal and subtropical) of eastern Spain were used as a model to study the effects of climate on composition and distribution of parasitoid communities. An introduction program with three parasitoid species of the scale was performed and the areas of establishment were identified. With the endoparasitoids, as its biology has been poorly studied, laboratory trials under simulated common and extreme climate conditions $\left(15,20,25\right.$ and $30^{\circ} \mathrm{C}$ combined with 25,45 and $\left.65 \% \mathrm{RH}\right)$ were performed to know parasitoid's life-history traits. In the inland area Aphytis melinus was the only parasitoid present, in the coastal it coexisted with Aphytis chrysomphali and in the subtropical also with Encarsia perniciosi. Comperiella bifasciata established in all inland groves where it was released whereas E. perniciosi and Aphytis lingnanensis only in the groves within the subtropical agroecosystem. In the laboratory, the highest intrinsic rate of increase $\left(r_{m}\right)$ values for C. bifasciata and E. perniciosi were reached at temperature-humidity regimes typical from inland and subtropical areas respectively. The longevity of both species at different temperature-humidity conditions also reflected their adaptability to dry or humid areas. Our results with CRS endoparasitoids, together with previous studies on Aphytis species, demonstrate the validity of $r_{m}$ analysis at different extreme temperature-humidity combinations to predict the potential areas of distribution of newly introduced organisms. Slight differences in average winter and summer temperatures or relative humidity between neighbour agroecosystems caused large variation in species composition and introduction success ratio.

Key words: Aonidiella aurantii, ectoparasitoid, endoparasitoid, humidity, temperature, life history, longevity. 


\section{1. Introduction}

The introduction of natural enemies of a non-indigenous species is considered the most environmentally desirable method for controlling the proliferation of exotic organisms (McEvoy and Coombs, 2000). Biological control through the introduction of parasitoids, the most promising natural enemies reducing insect pest populations, has been practiced for many years, but much remains to be discovered about the factors determining success or failure of introductions (Stiling, 1993; Greathead and Greathead, 1992; Gurr and Wratten, 2000; Mills, 2000). A high proportion of the parasitoids introduced to control pests failed to establish (Hall and Ehler, 1979; Stiling, 1993; Mills, 2000). These failures have often been attributed to the lack of previous data on the climatic requirements of the natural enemies (Greathead and Greathead, 1992; Gurr and Wratten, 2000) and the lack of match between these requirements and the target regions (DeBach and Argyriou, 1966; Stiling, 1993; Collier and Van Steenwyk, 2004; Goolsby et al., 2005).

Climatic factors directly affect the survival, development, reproduction and movement of insects and thus their potential distribution and their biotic potential or intrinsic rate of increase $\left(r_{m}\right)$ (Messenger, 1959; Willmer, 1982; Cammell and Knight, 1992; Southwood and Henderson, 2000). Temperature and relative humidity regimes are the major climate factors influencing biology, activity, and distribution of parasitoids in the field (Kfir and Luck, 1984; Duale, 2005; Kalyebi et al., 2005; Peacock et al., 2006; Sorribas et al., 2010). Life table parameters like development period, longevity, progeny production and sex ratio of parasitoids change with climatic conditions (Mann et al., 1990; Godfray, 1994; Liu et al., 1995; Kalyebi et al., 2005). Extreme temperatures may reduce survival, retard development and/or suppress reproduction of parasitoids (Hance et al., 2007; Pandey and Tripathi, 2008). Life-history traits determined in the laboratory can be useful indicators to predict insect responses in the field under different climatic conditions (Bale et al., 2002; Ward and Masters, 2007). Most laboratory experiments are focused on the optimal conditions whereas insects biology under suboptimal or extreme climatic conditions that naturally occur in the field are rarely considered (Hance et al., 2007).

The aphelinid ectoparasitoids of the genus Aphytis Howard, the most abundant and effective natural enemies associated with armored scale insects, are frequently released in classical biological control programs and have been often selected as model organisms for the study of competitive displacement and the 
distribution of introduced insects (Luck and Podoler, 1985; Bennet, 1993; Murdoch, et al., 1996). In this work we utilized the parasitoid community of California red scale, Aonidiella aurantii (Maskell) (Fig.1), to analyze the relation between the $r_{m}$ of parasitoids under different temperature and humidity conditions and their spatial distribution. The California red scale (CRS) is a hemipteran armored scale that infest citrus all around the world. The population of this key citrus pest can be reduced to low stable densities by the combination of different natural enemies (Reeve and Murdoch, 1986; Forster and Luck, 1996). The biology of the ectoparasitoids Aphytis has been widely studied, whereas the endoparasitoids complementing Aphytis activity have been, however, much less studied and only a few papers have revised its biology under optimal laboratory conditions (Richardson, 1978; Yu et al., 1990). That is the case of the two more important CRS endoparasitoid species, Comperiella bifasciata Howard and Encarsia perniciosi Tower (Atkinson, 1983; Forster et al., 1995; Asplanato and Garcia-Marí, 2002; Guirrou et al., 2003). The role of these endoparasitoids can be considered as complementary to the Aphytis since they can parasitize several scale instars that ectoparasitoids are not able to parasitize ( $\mathrm{Yu}$ et al., 1990; DeBach and Rosen, 1991; Rosen, 1994). Furthermore, it has been stated that scales from the twigs and the interior part of the tree canopy, that are less parasitized by Aphytis, are the preferred for parasitism by E. perniciosi (Yu et al., 1990; Borer et al., 2004; Sorribas and Garcia-Marí, 2010). The levels of total parasitism through the year were found to be highest in the groves where Aphytis parasitoids coexist with endoparasitoids (Sorribas and Garcia-Marí, 2010).

Failures on the establishment after introductory releases of $C$. bifasciata or E. perniciosi have been reported in citrus areas of California, Greece, Chile and Spain (DeBach 1948; Argyriou 1974; Lavandero et al., 2006; Pina and Verdú, 2007) whereas successful establishment of one or both parasitoid species has been reported in citrus regions of South Africa, California, Australia, Uruguay, Morocco and Italy (Atkinson, 1983; DeBach and Rosen, 1991; Smith et al., 1997; Asplanato and Garcia-Marí, 2002; Guirrou et al., 2003; Siscaro et al., 2008). In Australia, introductory releases with eight CRS parasitoids that were performed during more than 30 years only achieved the successful establishment of A. melinus in most citrus areas and the partial establishment of C. bifasciata and E. perniciosi in reduced citrus areas (Furness et al., 1983). 

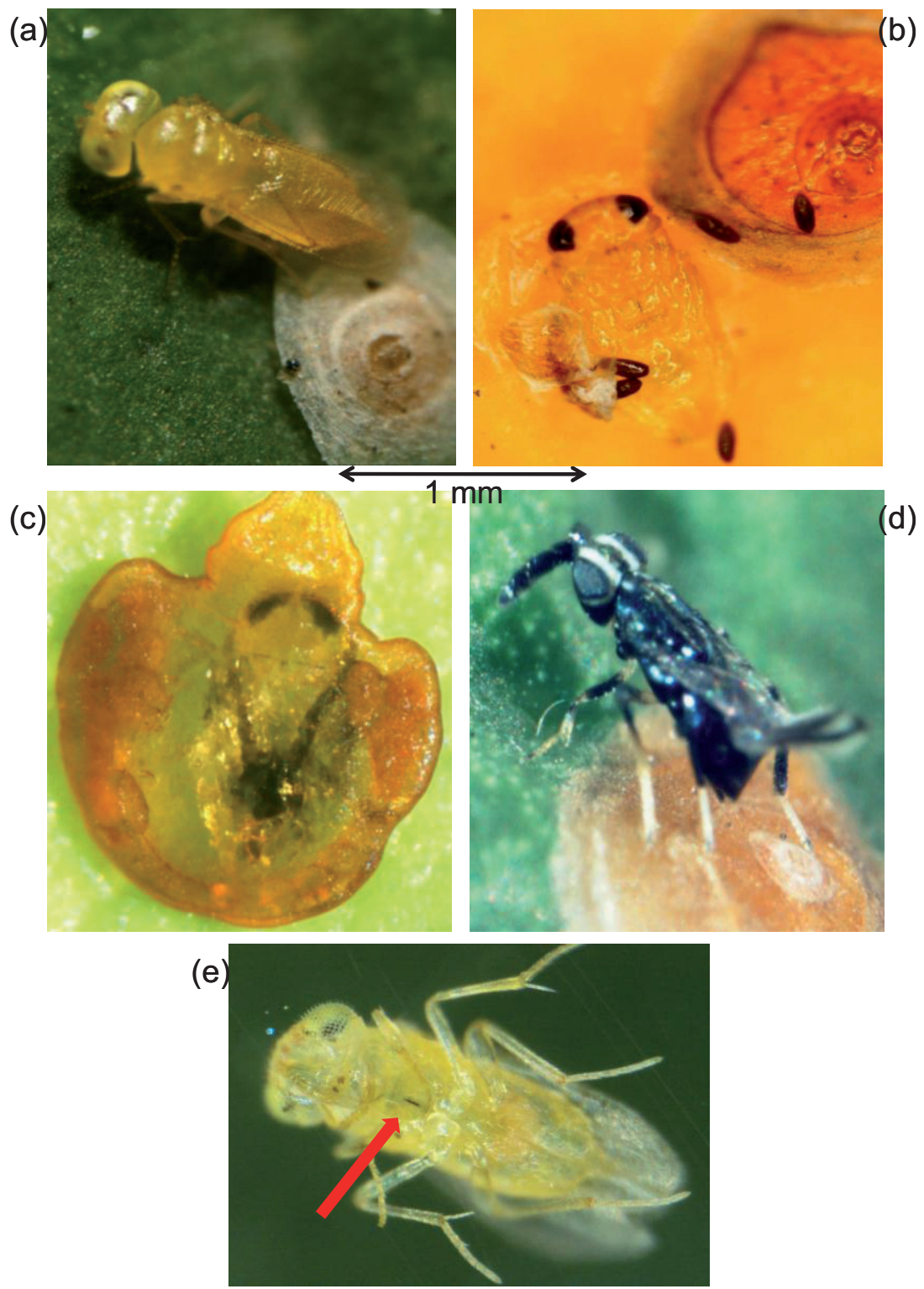

Fig. 1. Four parasitoids of the California red scale present in western Mediterranean. (a) Adult of Aphytis melinus trying to oviposit on a male red scale, (b) pupa of Aphytis chrysomphali after removing of the scale cover, (c) pupa of the endoparasitoid Encarsia perniciosi inside of the body of a young female scale, (d) adult of Comperiella bifasciata while ovispositing on a mature female scale (e) ventral view of Aphytis lingnanensis adult with the characteristic thorax black mark indicated. Photo credit: Juan Sorribas (C) 
In this paper we report on the results of 1) a field study to know the initial parasitoid community composition in three different citrus agroecosystems, 2) an introduction program with the two main CRS endoparasitoids, 3) laboratory assays to know more about the biology of C. bifasciata and E. perniciosi and to understand the effects of abiotic factors on life history traits and the $r_{m}$ of the parasitoids that could explain the success and failures of previous introductions. The aim was to integrate laboratory and field research to elucidate, using the California red scale parasitoids as models, how slight differences on climatic conditions of the habitat can influence the introduction and distribution of parasitoid species and how can this be explained through the $r_{m}$ of insect species at different temperature-humidity regimes. Our ultimate goal was to develop a method, based on the study of the $r_{m}$ under laboratory, to predict the potential areas of establishment and distribution of introduced parasitoids in relation to climate.

\section{2. Materials and methods}

\section{Study system}

Field study was performed in Eastern Spain, a historic citrus area of the western Mediterranean basin. The landscape of study consists of intensive agriculture composed mainly by small citrus groves of $<1$ ha spread over an extension of about 160,000 ha in an almost continuous belt, $300 \mathrm{~km}$ long from north to south and upto $70 \mathrm{~km}$ wide. The study area encompasses three connected habitat types (inland, coastal and subtropical Mediterranean agroecosystems). These ecosystems has been characterized and defined by its climate (meso-mediterranean, thermo-mediterranean and subtropical-humid mediterranean climate respectively), plant species composition and geographical distribution (Pérez, 1994; Costa, 1999; Millán et al., 2005; Alcaraz et al., 2006). Mean seasonal temperatures, summer drought and rainfall, the more important factors for distinguishing Mediterraneanclimate ecosystems (di Castri, 1981; Cowling et al., 2005), were considered to delimit these ecosystems. These biogeographical ecosystems are independent natural regions that had homogeneous climatic conditions. The inland agroecosystem, 30-70 $\mathrm{km}$ distant from the coast, is characterized by hot and dry summers and cold winters. The subtropical agroecosystem, the only area where tropical fruits are grown, is located in the south. This area, that contains two deep-humid valleys, has higher 
annual rainfall, relative humidity and winter temperatures than the others. The coastal areas present intermediate values, with higher temperature and relative humidity than the inland and lowers than the subtropical Mediterranean ecosystems (Pérez, 1994; Costa, 1999; Millán et al., 2005; Alcaraz et al., 2006). Climatic data were used from 31 weather stations distributed inside the ecosystems of study. Data for 14 meteorological variables were provided by the Spanish Instituto Nacional de Meteorología and the Valencian Agriculture Research Institute in the form of monthly values. Climatic information was gathered for 15 years (1996-2010). The selected variables for the purpose of this research were mean daily air temperature, mean daily relative humidity, mean annual rainfall (this to be closely related with humidity), absolute minimum daily temperature (we selected only the winter days), and absolute maximum daily temperature (we selected only the summer days). We calculated from the data the average annual temperature of the mean daily temperature, the average number of days with temperature $<0^{\circ} \mathrm{C}$ or days with frost, the average annual relative humidity, the average relative humidity during winter and the average relative humidity during summer. Summer and winter were selected to be the more definitory seasons of the year for parasitoids.

In Eastern Spain, like in many citrus areas around the world, CRS constitutes an invasive pest that has spread during the last decades, being present in most citrus groves (Alfaro et al., 1999; Castaño et al., 2008; Sorribas et al., 2010). Latest studies shows the introduced Aphytis melinus DeBach and the Mediterranean basin native Aphytis chrysomphali (Mercet) coexisting in similar proportion as the most important parasitoids (Pina and Verdú, 2007; Sorribas et al., 2008; Sorribas et al., 2010).

Literature about Aphytis biology and distribution around the world was revised and data about their $r_{m}$, development time, extreme cold and hot tolerance, humidity requirements and lower developmental threshold were collected and complemented with our field and laboratory data (see table 4).

\section{Parasitoid spatial patterns}

To study the parasitoid community composition associated to wild $A$. aurantii populations in the three ecosystems we collected samples from 121 sites (mature orange groves) distributed along the citrus-growing areas of Eastern Spain between January 2005 and September 2008. During this period each grove was sampled two times. Selected sites were separated by a minimum of $5 \mathrm{~km}$ trying to 
cover as much as possible the area of study. Samples consisted of twigs and fruits (when present) highly infested with $A$. aurantii from different trees of the grove. On each sampling date, 35-45 twigs about $30 \mathrm{~cm}$ long with leaves and 20-35 fruits were collected. In the laboratory, collected material was kept in rearing cages to capture

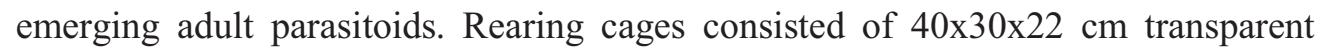
plastic boxes covered with gauze and maintained inside climatic chambers $\left(26-28^{\circ} \mathrm{C}\right.$, $60 \%$ relative humidity, $16: 8 \mathrm{~h}$ photoperiod) for 30 days to allow development of all parasitoids to adults. Adult parasitoids were captured on yellow sticky traps of $12 \times 12 \mathrm{~cm}$ placed inside the cages or collected dead from the bottom of the cage. All parasitoids were counted and identified to species level.

\section{Introduction of new parasitoid species}

During the period 2007-2008 an extensive introduction program of new parasitoid species was performed by the Agriculture Regional Government in order to improve the biological control of CRS. The selected parasitoids were $C$. bifasciata, E. perniciosi and Aphytis lingnanensis Compere. Parasitoids derived from a stock population reared in Insectarium (Almassora Insectarium, Agriculture Department of Valencia Region Government, Conselleria de Agricultura, Spain) on butternut squashes under $26 \pm 1^{\circ} \mathrm{C}$ and $\sim 60 \%$ relative humidity $(\mathrm{RH})$. Releases of the two endoparasitoids were performed in groves in which only Aphytis parasitoids where previously present. The introduction program was performed in sites previously sampled. Sites were spatially distributed along the three ecosystems of the study area with a minimum of $10 \mathrm{~km}$ between neighboring sites, a distance which was thought to guarantee independence between sites given the estimated dispersal distance of the parasitoids. Comperiella bifasciata were released in the 19 sites and E. perniciosi and A. lingnanensis in 12 sites (see Fig 1). Sites were selected to have high density of the host. Releases consisted in hanging from different trees of each site 2-3 butternut squashes, Cucurbita moschata (Duchesne), containing parasitized scales. About 2,000-3,000 parasitoid wasps in several generations were estimated to emerge from each squash throughout three to four months (squash duration depends on weather conditions).

To study the establishment of the released parasitoids a sampling process was carried out in the released sites during the period 2009-2010, one to two years after releases. We used the same sampling methodology described before. 


\section{Laboratory experiments}

Finally, laboratory trials with C. bifasciata and E. perniciosi parasitoids were conducted under different combinations of temperature and relative humidity regimes. We analyzed and compared the responses of both species to usual and extreme conditions of temperature and humidity that are naturally encountered in the ecosystems of study and the effects of different combinations of these climatic factors on life-history traits (development time, longevity, progeny production per female and sex-ratio) of the parasitoids.

To determine the $r_{m}$ under different temperature and $\mathrm{RH}$ regimes we used lemon fruits (Citrus limon (L.) Burm. f.) covered over 2/3 with paraffin wax with a semicircular non-paraffined area infested with about 200 second CRS stages. The second scale stage was selected as it is one of the preferred for parasitism of both parasitoid species (Flanders, 1944; Richardson, 1978; Yu et al., 1990). Lemons were individually introduced in cylindrical plastic box $(5 \mathrm{~cm}$ in diameter) with a fine mesh on the top. A newly emerged female parasitoid (E. perniciosi or C. bifasciata) was introduced in each box and a drop of diluted honey was added as food. Insects used for laboratory experiments had the same origin than those used for field releases. Females of C. bifasciata were previously confined for half an hour inside a tube containing males in order to mate (this usually occurs in one minute or less, personal observation).

These experiments were performed at four constant temperatures $\left(15^{\circ} \mathrm{C}\right.$, $20^{\circ} \mathrm{C}, 25^{\circ} \mathrm{C}$ and $30^{\circ} \mathrm{C} \pm 1{ }^{\circ} \mathrm{C}$ ) at a relative humidity ( $\left.\mathrm{RH}\right)$ of $65 \% \pm 1 \%$ and at two constant temperatures $\left(25^{\circ} \mathrm{C}\right.$ and $\left.30^{\circ} \mathrm{C} \pm 1{ }^{\circ} \mathrm{C}\right)$ at a $\mathrm{RH}$ of $45 \% \pm 1 \%$. As it is shown in Table 1 mean temperatures between $10^{\circ} \mathrm{C}$ (winter, no insect activity) and $25^{\circ} \mathrm{C}$ (summer) are common in the ecosystems of study and can be considered as common temperatures whereas a constant temperature of $30^{\circ} \mathrm{C}$ can be considered an extremely hot condition as it is reached only few days per year and it is about the average of the absolute daily maximum temperature during the summer. Similarly a $\mathrm{RH}$ of $65 \%$ can be roughly representative of the average common humidity conditions from coastal areas and RH of $45 \%$ from dry inland Mediterraneanclimate ecosystems. Generally, inland citrus areas, like the San Joaquin Valley (California), differ from coastal districts in having hotter summers, colder winters and lower relative humidity (DeBach et al., 1955; Carroll and Luck, 1984). Trials under a constant RH of $25 \%$ (see below) can be considered as representative of rare 
extremely dry conditions. The combinations of low relative humidity with the lower temperatures were discarded as these conditions rarely occur in nature.

Ten female parasitoid wasps of each species were used for each experiment. Every day the lemon was changed for another with the same characteristics until the death of the adult female parasitoid. Lemons were kept under the same conditions until the parasitoid progeny arrived to the adult stage. Adult emergence was checked daily and the approximate development time was estimated as the midpoint of the period between two consecutive observations during which emergence occurred. The total progeny emerged per each female parasitoid was counted and, in the case of $C$. bifasciata, the sex of the emerged insects was recorded.

To analyze and compare the effect of relative humidity on the adult endoparasitoid longevity, we introduced honey provided tubes (diameter $1.8 \mathrm{~cm}$, height $10 \mathrm{~cm}$ ), closed with a fine mesh in both extremes, inside of glass desiccators sealed with grease. A newly emerged endoparasitoid (C. bifasciata or E. perniciosi) was confined in each tube. Three constant humidity levels were selected for this experiment: $25 \%, 45 \%$ and $65 \% \pm 1 \% \mathrm{RH}$. To maintain the desired humidity inside, the bottom of each desiccator contained different sulphuric solutions (Sweetman, 1933; Solomon, 1951). Temperature was kept constant at $25 \pm 1^{\circ} \mathrm{C}$ (that is considered around the optimal for both parasitoids) for the three humidity levels and photoperiod was 16:8 day/night. Death of the parasitoids was recorded every day. The number of insects was 20 for each relative humidity and parasitoid species.

To analyze the influence of temperature on the longevity of adults, newly emerged endoparasitoids were separately introduced inside individual tubes (diameter $1.8 \mathrm{~cm}$, height $10 \mathrm{~cm}$ ) containing diluted honey as food. Tubes were closed with a fine mesh in one extreme and a water deposit separated with cotton in the other extreme. The mortality of the parasitoids at 3 constant temperatures: $15^{\circ} \mathrm{C}$, $20^{\circ} \mathrm{C}$ and $30^{\circ} \mathrm{C} \pm 11^{\circ} \mathrm{C}$ and $\sim 65 \% \mathrm{RH}$ (photoperiod $16: 8$ day/night) was recorded every day. For each temperature the number of replicates was 20 for E. perniciosi, 10 for $C$. bifasciata females and 10 for $C$. bifasciata male parasitoids.

\section{Data analysis}

Differences in the climatic data were analyzed through the comparison between the annual averages obtained for each of the weather station during the 15 years time series for each ecosystem as one-way Analysis of Variance (ANOVA) 
followed by post hoc comparisons using Bonferroni's multiple comparison tests. To determine if estimated values in the progeny, development time and sex ratio (proportion of females of C. bifasciata) at the six combinations of temperature and humidity (as shown in Table 2) differed significantly, data were analyzed as oneway ANOVA followed by pairwise comparisons using multiple comparison tests. Data on the percentages were arcsine squareroot-transformed before ANOVA to stabilize the variance. Differences in the longevity of adult parasitoids for the combinations with temperature and relative humidity variables were analyzed without transformation by one-way ANOVA with Bonferroni's post hoc multiple comparison tests to analyze the data either in lines or in columns. All analyses were performed in Statgraphics Centurion XVI statistical software (StatPoint Inc., Herndon, VA, USA).

The intrinsic rate of increase $\left(r_{m}\right)$ for $C$. bifasciata and E. perniciosi was estimated iteratively from our laboratory data at each temperature-humidity regime according to the Birch equation (Birch, 1948): $\sum_{0}^{\infty} \exp \left(-r_{m} x\right) \cdot l_{x} \cdot m_{x}=1$, where " $r_{m}$ " is the intrinsic rate of natural increase, " $\mathrm{x}$ " is female age, " $l_{x}$ " is the fraction of females surviving to age $\mathrm{x}$ and " $m_{x}$ " is the number of daughters produced per female alive at age $\mathrm{x}$. As we evaluated in the laboratory experiments the adult emergence of parasitoids from hosts (including the sex of parasitoids), the " $l_{x} m_{x}$ " product was directly obtained from the number of female daughters emerging at age $\mathrm{x}$. To facilitate comparison of the intrinsic rate of increase calculated for each temperatureRH combination, standard errors of $r_{m}$ estimates were calculated using the jack-knife algorithm described by Meyer et al. (1986).

\section{3. Results \\ Climatic data}

The analyses of the 15-year meteorological time-series show small but significant differences in mean daily temperature and relative humidity between the three studied agroecosystems. The highest differences were found in the average annual rainfall. Strong significant differences were also found between summer and 
winter temperatures of the three agroecosystems, mainly when we compared the average of the absolute daily minimum temperature during the winter and the average of the absolute daily maximum temperature during the summer. There were also significant differences between summer and winter relative humidity of each agroecosystem (Table 1).

Table 1. Mean temperature, relative humidity and rainfall (SE) of three Mediterranean agroecosystems of eastern Spain serving as habitat for different parasitoid communities for the period 1996-2010 (means of 11, 13 and 7 weather stations respectively).

\begin{tabular}{l|l|l|l|l|l|l|l|l} 
& \multicolumn{5}{|c|}{ Mean Temperature } & \multicolumn{2}{c|}{ Mean Relative Humidity } & $\begin{array}{c}\text { Mean } \\
\text { rainfall } \\
(\mathbf{m m})\end{array}$ \\
& \multicolumn{3}{|c|}{$\left({ }^{\circ} \mathbf{C}\right)$} & \multicolumn{2}{c}{$(\mathbf{\%})$} & \\
\hline $\begin{array}{l}\text { Mediterranean } \\
\text { ecosystem }\end{array}$ & Overall & $\begin{array}{l}\text { Absolute } \\
\text { Min. Temp. } \\
\text { Winter* }\end{array}$ & $\begin{array}{l}\text { Absolute } \\
\text { Max. Temp. } \\
\text { Summer* }\end{array}$ & $\begin{array}{l}\text { Number } \\
\text { days } \\
\text { T. min } \\
<0^{\circ} \mathrm{C}^{* *}\end{array}$ & Overall & Winter & Summer & Annual \\
\hline Inland & $16.7(0.5) \mathrm{b}$ & $4.6(0.83) \mathrm{c}$ & $32.4(0.9) \mathrm{a}$ & $5.5(1.7) \mathrm{a}$ & $64.1(1.8) \mathrm{b}$ & $66.4(2.1) \mathrm{b}$ & $62.5(2.0) \mathrm{b}$ & $468.1(22.7) \mathrm{c}$ \\
Coastal & $17.3(0.4) \mathrm{b}$ & $5.8(0.9) \mathrm{b}$ & $30.0(0.7) \mathrm{b}$ & $2.4(0.4) \mathrm{b}$ & $66.8(1.7) \mathrm{a}$ & $65.6(1.8) \mathrm{b}$ & $67.8(2.2) \mathrm{a}$ & $484.3(24.7) \mathrm{b}$ \\
Subtropical & $17.6(0.5) \mathrm{a}$ & $6.2(1.4) \mathrm{a}$ & $31.2(0.8) \mathrm{b}$ & $1.3(0.2) \mathrm{c}$ & $68.7(1.9) \mathrm{a}$ & $69.4(2.2) \mathrm{a}$ & $68.9(2.3) \mathrm{a}$ & $758.0(40.0) \mathrm{a}$
\end{tabular}

*Average of the absolute minimum or maximum temperature per day during winter or summer. **Average number of days per year in which temperature falls below $0^{\circ} \mathrm{C}$.

Note: Climatic data are from the Spanish National Agency of Meteorology and the Agriculture Department of the Valencia Region Government climatic database (http://www.aemet.es and http://estaciones.ivia.es).

\section{Parasitoid spatial patterns}

A total of 23235 parasitoid wasps were identified emerging from plant material. The results of the extensive sampling in 121 sites showed the introduced $A$. melinus to be the only parasitoid present in most inland sites $(98.4 \%$ of the total parasitoids, $\mathrm{n}=6476$ ), where the native $A$. chrysomphali has been almost totally 
displaced. Both parasitoids $A$. chrysomphali and A. melinus appeared in coexistence in coastal and subtropical ecosystems $(47.7 \%$ and $28.5 \%$ of the total parasitoids respectively, $\mathrm{n}=11251$ and 5501). Encarsia perniciosi was found in seven sites, where this endoparasitoid was naturally present without any previous release program. All sites in which E. perniciosi was present were located within the subtropical ecosystem. In fact, in most sampled sites of the subtropical ecosystem $E$. perniciosi was recovered, so this species, although it is not native, can be considered as naturalized in this region. In these sites E. perniciosi coexisted with A. melinus and $A$. chrysomphali, representing $14.6 \%(\mathrm{n}=803)$ of all parasitoids obtained in this area. Marietta carnesi (Howard), a known hyperparasitoid of E. perniciosi (Viggiani, 1990), was found (7 specimens) in groves where E. perniciosi was present at high levels. Comperiella bifasciata and A. lingnanensis were not present in any of the sampled ecosystems.

\section{Introduction of new parasitoid species}

Comperiella bifasciata was recovered only in the four sites located in the inland area; whereas no recovery was observed in the 15 remaining sites located either in coastal or subtropical areas. In these four sites, C. bifasciata appeared in coexistence with $A$. melinus, being both the sole existing parasitoids. Comperiella bifasciata achieved significant population levels only one year after the releases. The 128 specimens found represented $7.3 \%$ of the total parasitoids captured in these sites.

Encarsia perniciosi was recovered in the two sites located in the subtropical ecosystem (where it was not present before), out of the 12 sites where it was released (seven in the coastal, three in the inland and two in the subtropical ecosystem), and $A$. lingnanensis was recovered only in one grove in the same ecosystem (Fig. 2). The 47 E. perniciosi captured represented $10.2 \%$ of all parasitoids captured in the two released sites and the 128 A. lingnanensis captured represented $41.2 \%$ of the parasitoids captured in the released site. In these sites coexisted with $A$. melinus and A. chrysomphali. 


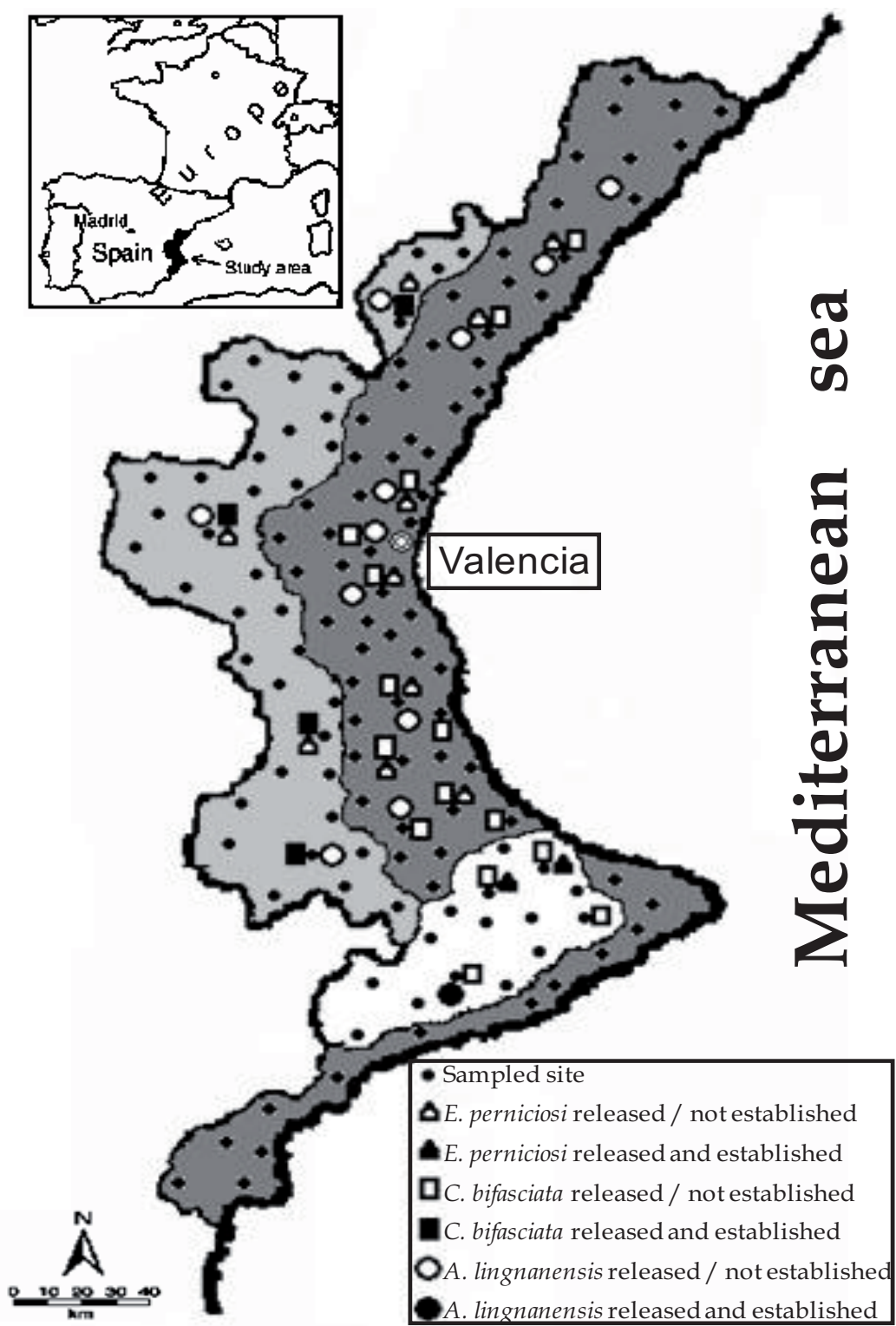

Fig. 2. Mediterranean agroecosystems of eastern Spain and predominant parasitoids of California red scale. Inland ecosystem: Aphytis melinus (light grey color). Coastal ecosystem: Aphytis melinus and A. chrysomphali (dark grey color). Subtropical ecosystem: Aphytis melinus, Aphytis chrysomphali and $E$. perniciosi (white color). The distribution of the sampled sites (mature citrus groves) is indicated with small black dots. Release sites for the introduced parasitoids Encarsia perniciosi, Comperiella bifasciata and A. lingnanensis are indicated with triangle, square and circle figures (white color if not established and black if established). 


\section{Laboratory experiments}

As expected, development time significantly decreased with temperature for both analyzed parasitoids. The calculated lower developmental threshold was $11.6^{\circ} \mathrm{C}$ for E. perniciosi and $9.9^{\circ} \mathrm{C}$ for C. bifasciata (Fig. 3). The $r_{m}$ increased with temperature at $65 \% \mathrm{RH}$, reaching its maximum at the highest temperature tested of $30^{\circ} \mathrm{C}$, with $r_{m}=0.259$ for E. perniciosi and $r_{m}=0.185$ for C. bifasciata (Table 2). This was consequence of a marked decrease in the development period with temperature in spite of the highest progeny being reached at $25^{\circ} \mathrm{C}$.

Fig. 3. Relationship between Encarsia perniciosi and Comperiella bifasciata developmental rates (1/day) and temperature (experiments under constant relative humidity of $65 \%$ ). Regression equations were: $y=0.023 x-0.0228, \quad R^{2}=0.9948$ and $y=0.031 x-\quad 0.0359, \quad R^{2}=0.9918$ respectively.
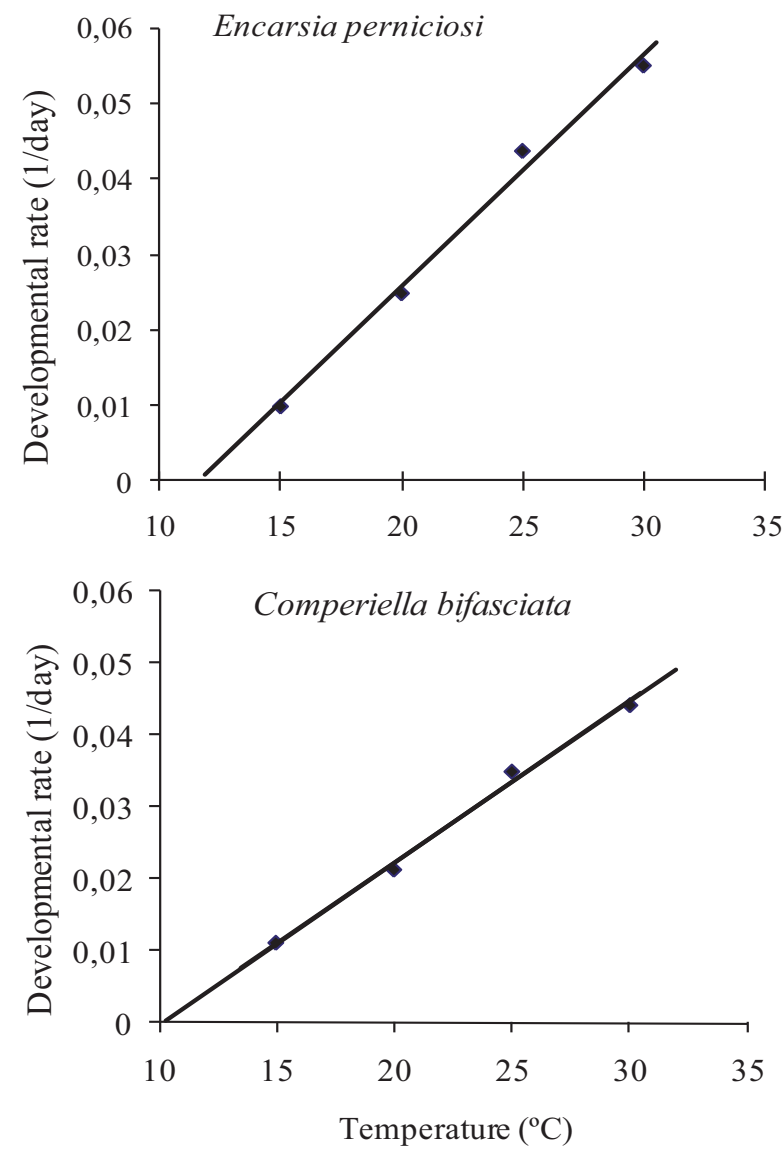

The $r_{m}$ was higher for E. perniciosi under all temperature regimes except for the lower temperature tested (most specimens died without oviposition and only 18 parasitoids completed development to adult). This was consequence of the longer development time and the sex ratio of $C$. bifasciata (close to $1: 1$ as average), while 
all E. perniciosi descendants were females. In contrast, when the tests were repeated at a lower $\mathrm{RH}$ regime $(45 \%)$, E. perniciosi showed a very low progeny at $25^{\circ} \mathrm{C}$ (and thus a low $r_{m}$ value), and no oviposition at $30^{\circ} \mathrm{C}$. Interestingly, C. bifasciata performed much better at this $\mathrm{RH}$ regime, mostly due to a higher progeny, reaching an $r_{m}$ of 0.201 at $30^{\circ} \mathrm{C}$.

The proportion of $C$. bifasciata females emerged was nearly $50 \%$ in most combinations tested except for the extreme conditions of $30^{\circ} \mathrm{C} / 45 \% \mathrm{RH}$ and $15^{\circ} \mathrm{C} /$ $65 \% \mathrm{RH}$ which caused a significantly more male biased sex ratio $\left(F_{2,20}=6.84\right.$, $\mathrm{P}=0.006$ ) than in the trials at $20^{\circ} \mathrm{C}$ and $25^{\circ} \mathrm{C}$ (Table 2).

Table 2. Influence of common and extreme climate conditions (four constant temperatures and two relative humidity regimes) on the progeny, developmental period and intrinsic rate of increase (SE) of newly emerged parasitoids of the species Encarsia perniciosi and Comperiella bifasciata. Progeny, mean number of adults emerged per female ${ }^{*}$. Mean immature developmental period, days from oviposition to adult emergence. Standard error of $r_{m}$ calculated using the jackknife algorithm.

"Food (honey) always available

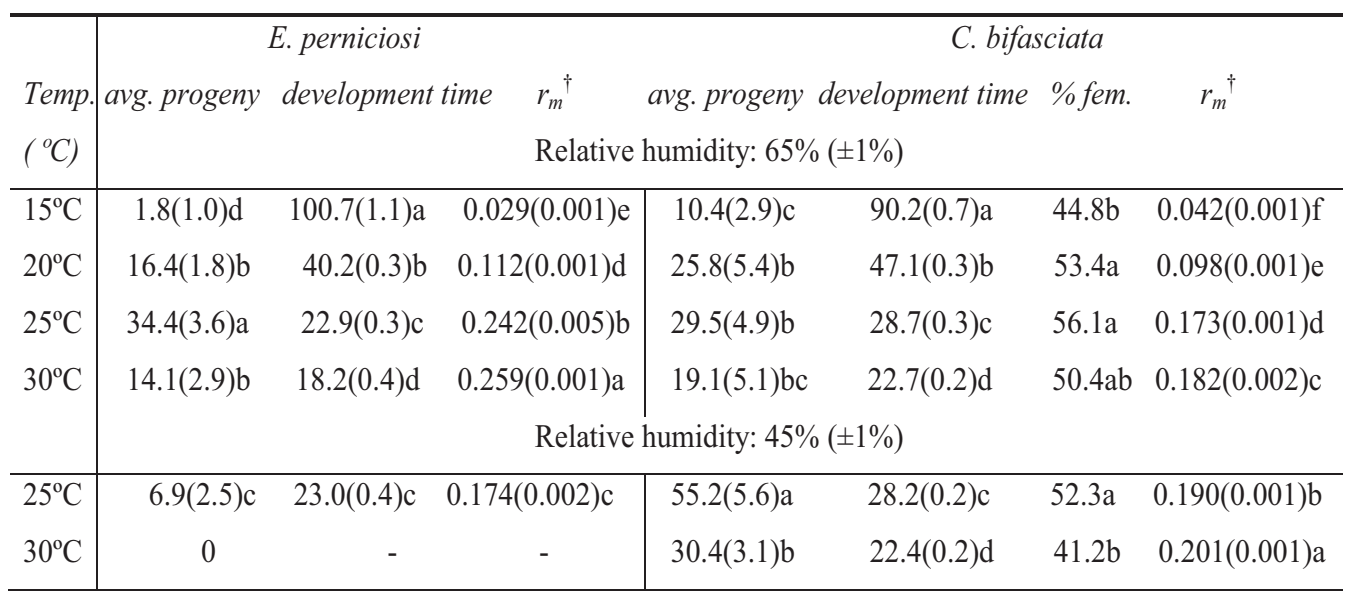

*n: total progeny produced ${ }^{\dagger} r_{m}$ : Intrinsic Rate of Increase Values in the same column followed by the same letter are not significantly different for ANOVA with Bonferroni's multiple range test $(\mathrm{P}>0.05)$.

The life span of C. bifasciata adult females without hosts was significantly longer than $E$. perniciosi, under all relative humidity values studied when temperature was constant $\left(F_{1,33}=66.34, P<0.0001\right.$ at $25 \% \mathrm{RH} ; F_{1,32}=18.65, P=0.0002$ 
at $45 \% \mathrm{RH} ; F_{1,25}=17.91, P=0.0003$ at $\left.65 \% \mathrm{RH}\right)$, reaching up to 26 days for $C$. bifasciata females and up to 11.3 days for E. perniciosi at $65 \%$ RH. Life span was shorter as RH decreased, mainly for E. perniciosi which survived only for three days on average at $25 \% \mathrm{RH}$ (Table 3).

Table 3. Influence of three relative humidity regimes at constant temperature $\left(25^{\circ} \mathrm{C} \pm 1^{\circ} \mathrm{C}\right)$ and three constant temperature regimes at constant relative humidity $(65 \% \pm 1 \%)$ on adult longevity (mean number of days between emergence and death) (SE) of newly emerged Encarsia perniciosi $(\mathrm{n}=\mathbf{2 0})$ and Comperiella bifasciata $(\mathrm{n}=\mathbf{2 0}, 10$ females and 10 males) parasitoids".

"Food (honey) always available

\begin{tabular}{|c|c|c|c|}
\hline \multirow{2}{*}{$\begin{array}{c}\text { LONGEVITY } \\
\text { (days) }\end{array}$} & \multicolumn{3}{|c|}{ Constant temperature $\left(25^{\circ} \mathrm{C} \pm 1\right)$} \\
\hline & E. perniciosi & C. bifasciata fem. & C. bifasciata males \\
\hline RH: $25 \% \pm 1$ & $3.0(0.2) \mathrm{Bc}$ & $10.2(1.3) \mathrm{Ab}$ & 7.8(0.9)Ab \\
\hline RH: $\mathbf{4 5 \%} \pm 1$ & $8.6(0.7) \mathrm{Bb}$ & 17.8(1.5)Aab & 14.2(0.9)Aa \\
\hline \multirow[t]{3}{*}{ RH: $65 \% \pm 1$} & $11.4(0.9) \mathrm{Ba}$ & 26.6(4.1)Aa & 13.6(2.0)Ba \\
\hline & \multicolumn{3}{|c|}{ Constant relative humidity $(65 \% \pm 1)$} \\
\hline & E. perniciosi & C. bifasciata fem. & C. bifasciata males \\
\hline Temp: $15^{\circ} \mathrm{C} \pm 1$ & 34.4(3.4)Ba & 59.1(8.2)Aa & 53.5(4.9)Aa \\
\hline Temp: $20^{\circ} \mathrm{C} \pm 1$ & 18.3(2.7)Bab & 42.9(5.9)Aab & 19.8(3.6)Bab \\
\hline Temp: $30^{\circ} \mathrm{C} \pm 1$ & 7.6(0.8)Bc & 18.5(2.4)Acd & $13.3(2.0) \mathrm{Ab}$ \\
\hline
\end{tabular}

Values within the same line followed by the same capital letter or within the same column followed by the same lower case letter are not significantly different, ANOVA, Bonferroni's multiple range test $(\mathrm{P}>0.05)$. RH: Relative humidity, Temp: Temperature, SE: Standard Error.

Similarly, at all temperatures tested under constant RH, adult females of $C$. bifasciata exhibited longer life span than E. perniciosi $\left(F_{1,24}=5.07, P=0.0342\right.$ at $15^{\circ} \mathrm{C} ; F_{1,23}=17.36, P=0.0004$ at $20^{\circ} \mathrm{C} ; F_{1,24}=14.21, P=0.0010$ at $25^{\circ} \mathrm{C} ; F_{1,24}=24.77$, $P<0.0001$ at $\left.30^{\circ} \mathrm{C}\right)$. Longevity of both species was longer at lower temperatures reaching high values (nearly two months) in $C$. bifasciata at the lower temperature tested of $15^{\circ} \mathrm{C}$. Longevity of C. bifasciata females was longer than C. bifasciata males at $65 \% \mathrm{RH}-25^{\circ} \mathrm{C}\left(F_{1,20}=8.49, P=0.0089\right)$ and $65 \% \mathrm{RH}-20^{\circ} \mathrm{C}\left(F_{1,21}=11.89\right.$, 
$P=0.0025$ ) (Table 3). The patterns of survival under constant temperature and relative humidity for E. perniciosi and C. bifasciata females are shown in Fig. 4.

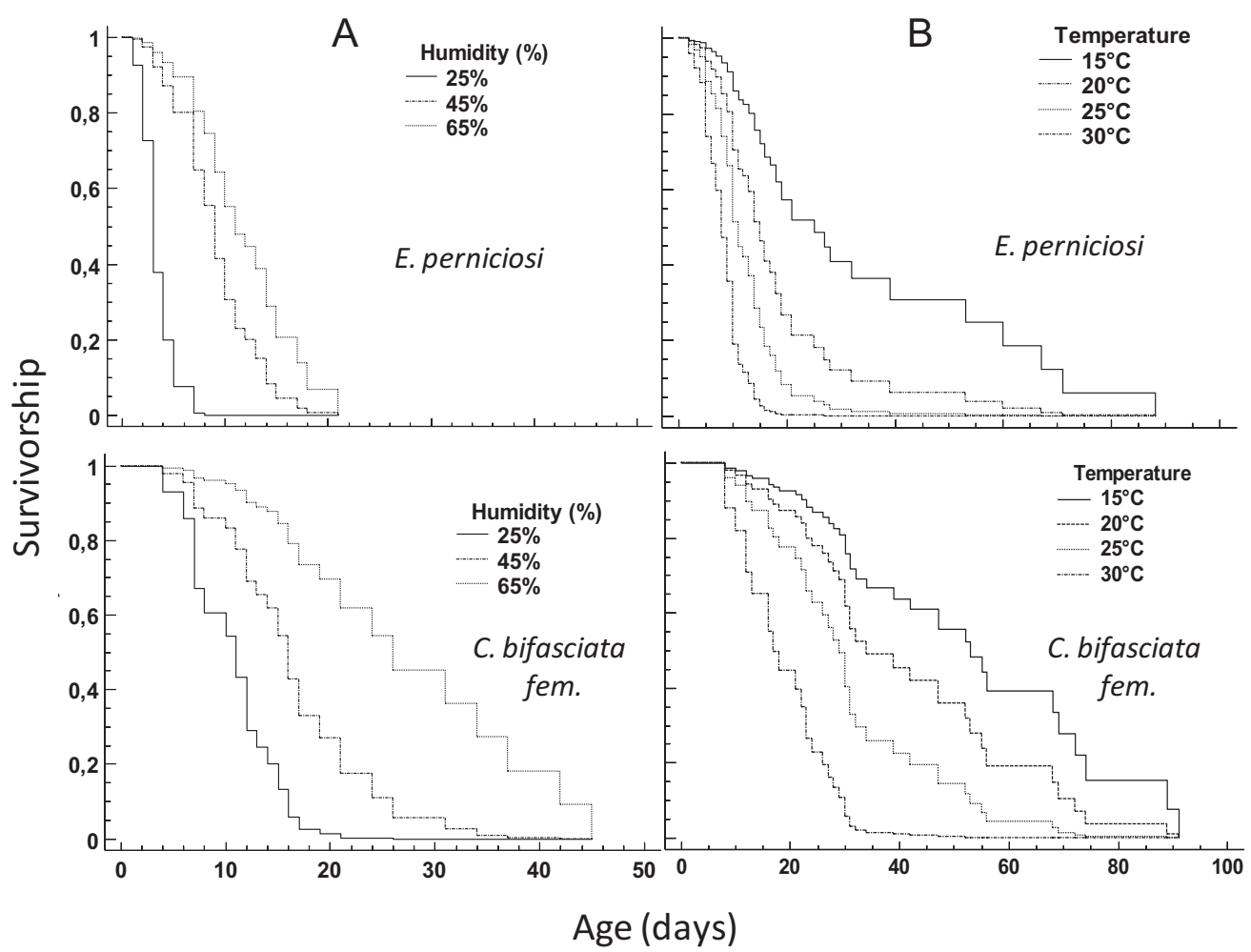

Fig. 4. Patterns of survival for Encarsia perniciosi and Comperiella bifasciata adult females under A) constant temperature of $25^{\circ} \mathrm{C}$ combined with three different relative humidity conditions $(25 \%, 45 \%$ and $65 \%)$ and $\mathrm{B})$ constant relative humidity of $65 \%$ and four temperatures $\left(15^{\circ} \mathrm{C}\right.$, $20^{\circ} \mathrm{C}, 25^{\circ} \mathrm{C}$ and $30^{\circ} \mathrm{C}$ ).

Summarizing, E. perniciosi showed low tolerance to cold and hot extremes temperatures and high humidity requirements whereas $C$. bifasciata showed higher phenotypic plasticity as it presented very high tolerance to both extreme hot and cold temperatures and resistance to low humidity conditions. This is collected in Table 4 together with data from literature about the climate requirements for the other parasitoid species. 
Table 4. Responses to temperature and humidity of natives to the Mediterranean basin and introduced parasitoid species of Aonidiella aurantii and ecosystems of distribution in western Mediterranean basin.

\begin{tabular}{|c|c|c|c|c|c|c|c|}
\hline Parasitoid wasp & $\begin{array}{l}\mathrm{r}_{\mathrm{m}} \text { at } \\
25^{\circ} \mathrm{C}\end{array}$ & $\begin{array}{l}\text { Development } \\
\text { time at } 24- \\
25^{\circ} \mathrm{C}\end{array}$ & $\begin{array}{l}\text { Extreme cold } \\
\text { tolerance }\end{array}$ & $\begin{array}{l}\text { Extreme hot } \\
\text { tolerance }\end{array}$ & $\begin{array}{l}\text { Humidity } \\
\text { requirement }\end{array}$ & $\begin{array}{l}\text { Lower } \\
\text { development } \\
\text { threshold }\end{array}$ & $\begin{array}{l}\text { Mediterranean } \\
\text { ecosystems of } \\
\text { distribution }\end{array}$ \\
\hline
\end{tabular}

\begin{tabular}{|c|c|c|c|c|c|c|c|}
\hline $\begin{array}{l}\text { NATIVES } \\
\text { (or naturalized*) }\end{array}$ & & & & & & & \\
\hline $\begin{array}{l}\text { Aphytis } \\
\text { chrysompali }\end{array}$ & $0.15^{\mathrm{a}}$ & 16.1 days $^{\mathrm{a}}$ & $\operatorname{High}^{\mathrm{a}}$ & Low $^{\mathrm{a}, \mathrm{c}}$ & $\operatorname{High}^{\mathrm{d}}$ & $8.5^{\circ} \mathrm{C}^{\mathrm{a}}$ & $\begin{array}{l}\text { Coastal } \\
\text { Subtropical }\end{array}$ \\
\hline $\begin{array}{l}\text { Encarsia } \\
\text { perniciosi* }^{*}\end{array}$ & $0.17^{\mathrm{f}}$ & 22.9 days $^{\mathrm{f}}$ & Very low ${ }^{\mathrm{f}}$ & Low $^{\text {f }}$ & Very high $^{\mathrm{f}}$ & $11.8^{\circ} \mathrm{C}^{\mathrm{f}}$ & Subtropical \\
\hline INTRODUCED & & & & & & & \\
\hline $\begin{array}{l}\text { Aphytis } \\
\text { melinus }\end{array}$ & $0.14^{\mathrm{a}}$ & 15.5 days $^{\mathrm{a}}$ & Medium $^{\mathrm{a}}$ & Very high $^{\mathrm{b}, \mathrm{c}, \mathrm{c}}$ & Low $^{\mathrm{d}}$ & $11^{\circ} \mathrm{C}^{\mathrm{a}}$ & All \\
\hline $\begin{array}{l}\text { Aphytis } \\
\text { lingnanensis }\end{array}$ & $0.15^{\dagger}$ & 15.7 days $^{\mathrm{c}}$ & Very low $^{\mathrm{c}, \mathrm{d}}$ & $\operatorname{High}^{\mathrm{c}, \mathrm{d}}$ & $\operatorname{High}^{\mathrm{d}}$ & $11.5^{\circ} \mathrm{C}^{\mathrm{c \dagger \dagger}}$ & $\begin{array}{l}\text { Coastal } \\
\text { Subtropical }\end{array}$ \\
\hline $\begin{array}{l}\text { Comperiella } \\
\text { bifasciata }\end{array}$ & $0.24^{\mathrm{f}}$ & 29.1 days $^{\mathrm{f}}$ & Very high $^{\mathrm{a}, \mathrm{f}}$ & Very high $^{\mathrm{a}, \mathrm{f}}$ & Low $^{\mathrm{f}}$ & $10.4{ }^{\circ} \mathrm{C}^{\mathrm{f}}$ & Inland \\
\hline
\end{tabular}

${ }^{\mathrm{a}}$ Abdelrahman (1974a), ${ }^{\mathrm{b}}$ Abdelrahman (1974b), ${ }^{\mathrm{c}}$ Kfir and Luck (1979), ${ }^{\mathrm{d}}$ Kfir and Luck (1984), ${ }^{\mathrm{f}}$ Present study extrapolated from DeBach and Sisojevic (1960) ${ }^{\dagger \dagger}$ extrapolated from Kfir and Luck (1984)

\subsection{Discussion}

The importance of importing and introducing nonexistent parasitoids in the biological control of CRS was emphasized many years ago when DeBach (1953) showed that releases of E. perniciosi in Los Angeles (California) filled an important niche in the successful biological control of CRS and complemented the action of existing parasitoids. Similarly, C. bifasciata, which was massively released, complemented A. melinus in the interior areas of California, being both responsible for a great reduction of the pest (DeBach and Rosen, 1991).

The results of our introduction and sampling programs show how slight differences in temperature and humidity conditions of contiguous ecosystems can be decisive for the successful establishment of parasitoids demonstrating the 
importance of a previous deep knowledge on the biology and climate requirements of selected species for introduction. The importance of considering not only overall average temperatures of the target area but also other climatic factors as winter and summer temperatures or humidity is emphasized by the fact that parasitoid species composition of two neighbor areas drastically differ as winter and summer average temperatures are few degrees lower or higher or relative humidity is slightly different. Much of the research focused on climate effects on ectotherms has been concerned with the responses of species to mean temperature. However, many other components of climate can alter species ranges and their established interactions. Between them, the relative humidity is probably one of the less considered. As suggested by Sieman et al. (1998) and Villalpando et al. (2009), studies using multiple climate factors and different combinations of these factors provide a more realistic approach to understand the effects of climate on insect community structure. Whereas laboratory experiments with Aphytis species cultured together at constant temperature and humidity regimes largely confirm that one species is always eliminated (Kfir and Luck, 1984; Luck and Podoler, 1985; Bennet, 1993) coexistence between Aphytis species in the field has been corroborated in many citrus areas (Luck and Podoler, 1985; Dahms and Smith, 1994; Asplanato and Garcia-Marí, 2002; Sorribas et al., 2010) confirming the importance of temperature and humidity effects at different levels besides the optimal.

In our study, only the most adaptive parasitoid, A. melinus (Rosen and DeBach, 1979), was present in the three agroecosystems, alone or in coexistence with other parasitoids, showing high phenotypic plasticity, while A. chrysomphali was abundant in coastal-humid areas. The higher phenotypic plasticity of many introduced species has been cited as a reason for the displacement of native species (Chown et al., 2007). Our field sampling showed that the introduced parasitoid wasp A. melinus has displaced the native A. chrysomphali from the dry and hot (during the summer) inland ecosystem and is present in high proportion in coastal and subtropical habitats.

Abdelrahman (1974b) found that A. chrysomphali had similar $r_{m}$ than $A$. melinus at 20 and $25^{\circ} \mathrm{C}$ but at $30^{\circ} \mathrm{C}$ the $r_{m}$ markedly decreased for $A$. chrysomphali whereas for A. melinus it reached its maximum. This could be another explanation for the A. chrysomphali displacement from the inland ecosystem, with summer temperatures often reaching values above $30^{\circ} \mathrm{C}$ while both species coexist in coastal areas where summer temperatures are lower. Similarly, in the laboratory experiments $C$. bifasciata reached its highest $r_{m}$ under the maximum temperature 
tested $\left(30^{\circ} \mathrm{C}\right)$ combined with low $\mathrm{RH}(45 \%)$, whereas in the same climatic conditions $E$. perniciosi was not able to oviposit. This reflects the adaptability of $C$. bifasciata to establish and develop in inland and/or dry areas. The high longevity measured for $C$. bifasciata adults at low temperature suggests that it is also well adapted the cold winters typical from inland areas, allowing adults to oviposit at the beginning of the spring. Encarsia perniciosi reached its maximum $r_{m}$ at the combination of $30^{\circ} \mathrm{C}$ and $65 \% \mathrm{RH}$ which can be considered typical climatic conditions for subtropical regions. This is coincident with the distribution and establishment areas of E. perniciosi in our field samples. This result, together with the comparatively short longevity reached by the adults of E. perniciosi at the low RH experiment, clearly indicates that this species needs moist-warm habitats to develop. This means the simple comparison between $r_{m}$ values of ectotherm species at one constant temperature does not necessarily inform about the predominant species in a particular habitat. However, the study of the $r_{m}$ under different usual and extreme temperature-humidity conditions could constitute a valid method to predict the potential areas of establishment and distribution of introduced insects.

The laboratory results in relation to temperature and humidity responses and the life-history traits of the evaluated endoparasitoids perfectly explain their establishment and field distribution in each of the analyzed habitats. This also explains its geographical distribution in different citrus areas around the world observed by numerous authors (e.g. Rosen and DeBach, 1978; Atkinson, 1983; Smith et al., 1997). Thus, although other factors like the tritrophic interactions can be important, the main factors explaining geographical ranges of these parasitoid species are apparently the air temperature and relative humidity. This can be observed, for instance, through the comparatively short longevity reached by the adults of E. perniciosi at the lowest RH, in relation to the longevity measured for $C$. bifasciata adults under the same conditions. Thus, as suggested by Ward and Masters (2007), life-history traits (and mainly the $r_{m}$ value) at different temperaturehumidity conditions of introduced insects can be used as indicators of its future invasive potential and spread.

The high temperature developmental threshold and humidity requirements of E. perniciosi could explain the unsuccessful establishment of this species in Spain during previous releases as they were performed in areas with low relative humidity and cold winters. The same can be said for A. lingnanensis, which only established in the subtropical area due to its high humidity requirements and low resistance to cold temperatures. Similarly, unsuccessful attempts for introduction of C. bifasciata 
in coastal California and coastal Spain are explained by the adaptation of this species to inland dry areas where it only competes with A. melinus. Stiling (1993), in his extensive list of examples of unsuccessful releases of natural enemies determined the climate as the first reason for the failures. Rosen and DeBach (1978) indicated that from 52 species of natural enemies introduced in California against $A$. aurantii only 8 became established. The climatic and life table characterization of purposefully introduced parasitoids allows us to describe the most suitable habitat and to predict possible niche overlap with extant parasitoid species. The laboratory and field results with the endoparasitoids $C$. bifasciata and E. perniciosi, together with field distribution and previous knowledge on the biology of Aphytis species, demonstrate the validity of $r_{m}$ analysis at different extreme temperature-humidity regimes to predict the potential areas of distribution of newly introduced parasitoids. Probably a new revision of these species considering their $r_{m}$ at different temperature-humidity regimes would give the necessary information to select the adequate habitats for the introduction of these species. Laboratory experiments with this $r_{m}$-method could also predict the potential risks of the introduction of inadequate alien species in biological control programs and the spread to non target areas where they could interact with other organisms.

Temperature and humidity regimes affect longevity, the number of parasitized hosts (and thus the progeny production in solitary parasitoids), the sex ratio and the biotic potential of parasitoid species. We have demonstrated that, besides temperature, humidity is a decisive factor for the fitness of parasitoid species, being humidity conditions of one specific area an important limiting factor that can prevent or allow the establishment of parasitoids. Our field and laboratory results demonstrate that, in order to identify the adequate areas for introduction of new species it is crucial to consider not only overall average temperatures of the target area but other climatic factors like winter and summer temperatures and relative humidity. Experiments on parasitoids responses under suboptimal temperatures (either hot or cold) and the temperature limits for development, oviposition, etc. result in a better knowledge of the efficacy of parasitoids in controlling the host through the year and can be a valuable weapon on decisions about areas and periods of introduction of new parasitoid species. Because climate change affects parasitoids differently and as we have shown that they are very sensitive to small variations in temperature or humidity, the distribution areas of each species may vary due to climate warming. These types of studies could be 
useful to forecast the expansion of invasive organisms arriving to a new area under current and future climates.

\section{Ackowledgements}

We thank Alberto García from the Almassora Insectarium (Conselleria de Agricultura, Spain) for the supply of parasitoids, Jacques van Alphen (Leiden University, The Netherlands) for his advices on laboratory trials, $\mathrm{M}^{\mathrm{a}}$ Jesús Verdú (Instituto Valenciano de Investigaciones Agrarias, Spain), Mamen Laurin and Juan Felipe Rodríguez (Silla Insectarium, Conselleria de Agricultura) for the information on parasitoid releases, Mohanad Ismail (ECOBIO Institute, France) for help during insect rearing and statistical analysis, Cecile Le Lann and Joffrey Moiroux (ECOBIO Institute) for help with laboratory experiments and the Citrus Phytosanitary Survey staff (Tragsatec - Agriculture Department of the Valencia Community Government) for many field samples. This work was partially supported by a Mobility Grant from the European University of Brittany (France) and by the AGL2005-07155-C03-03 project of the Spanish Ministry of Education and Science.

\subsection{Literature cited}

Abdelrahman, I., 1974a. The effect of extreme temperatures on California red scale, Aonidiella aurantii (Mask.) (Hemiptera: Diaspididae) and its natural enemies. Australian Journal of Zoology 22, 203-212.

Abdelrahman, I., 1974b. Growth, development and innate capacity for increse in Aphytis chrysomphali Mercet and A. melinus DeBach, parasites de California red scale, Aonidiella aurantii (Mask.), in relation to temperature. Australian Journal of Zoology 22, 213-230.

Alcaraz, D., Paruelo, J., Cabello J., 2006. Identification of current ecosystem functional types in the Iberian Peninsula. Global Ecology and Biogeography 15, 200-212.

Alfaro, F., Cuenca, F., Esquiva M., 1999. Problemática actual del piojo rojo de California en la C. Valenciana. Comunitat Valenciana Agraria 95, 54-60.

Argyriou, L.C., 1974. Data on the biological control of citrus scales in Greece. OILB/WPRS Bulletin 3, 89-94.

Asplanato, G., Garcia-Marí, F., 2002. Parasitismo de la cochinilla roja californiana $-154-$ 
Aonidiella aurantii (Homoptera: Diaspididae) en la zona citrícola sur de Uruguay. Boletín Sanidad Vegetal Plagas 28, 5-20.

Atkinson, P.R., 1983. Environmental factors associated with fluctuations in the numbers of natural enemies of a population of red scale, Aonidiella aurantii (Maskell) (Hemiptera: Diaspididae). Bulletin of Entomological Research 73, 417-426.

Bale, J.S., Masters, G.J., Hodkinson, I.D., Awmack, C., Bezemer, T.M., Brown, V.K., Butterfield, J., Coulson, J.C., Farrar, J., Good, J.G., Harrington, R., Hartley, S.E., Jones, T.H., Lindroth, R.L., Press, M.C., Syrmnioudis, I., Watt, A.D., Whittaker, J.B., 2002. Herbivory in global climate change research: direct effects of rising temperature on insect herbivores. Global Change Biology 8, 1-16.

Bennet, F.D., 1993. Do introduced parasitoids displace native ones? Florida Entomologist 76, 54-63.

Birch, L.C., 1948. The intrinsic rate of natural increase of an insect population. Journal of Animal Ecology 17, 15-26.

Borer, E.T., Murdoch, W.W., Swarbrick, S.L., 2004. Parasitoid coexistence: linking spatial field patterns with mechanism. Ecology 85, 667-678.

Cammell, M.E., Knight, J.D. 1992. Effects of Climatic Change on the Population Dynamics of Crop Pests. Advances in Ecological Research, 22, 117-162.

Carroll, D.P., Luck, R.F., 1984. Within-tree distribution of California red scale, Aonidiella aurantii (Maskell) (Homoptera; Diaspididae), and its parasitoid Comperiella bifasciata Howard (Hymenptera: Encyrtidae) on orange trees in the San Joaquin Valley. Environmental Entomology, 13, 179-183.

Casas, J., Swarbrick, S., Murdoch, W. W. ,2004. Parasitoid behaviour: predicting field from laboratory. Ecological Entomology 29, 657-665.

Castaño, A., Escrig, B., Guillén, M., López, O., Llopis, M., Martínez, A.B., Moreira, A., Peris L., Pérez, J.J., Sepúlveda, J., Vicente, M., García-Marí, F., Guitián, J.M., Baraja, M.P., Llorens, J.M., Moner, P., Dalmau V., 2008. Seasonal trend of California red scale (Aonidiella aurantii) populations in eastern Spain 2005-2007. OILB/WPRS Bulletin 38, 25. 
Chown, S.L., Slabber, S., McGeoch, M.A., Janion, C., Leinaas, H.P., 2007. Phenotypic plasticity mediates climate change responses among invasive and indigenous arthropods. Proceedings of the Royal Society of London B 274, 2531-2537.

Cowling, R.M., Ojeda, F., Lamont, B.B., Rundel, P.W., Lechmere-Oertel, R., 2005. Rainfall reliability, a neglected factor in explaining convergence and divergence of plant traits in fire-prone mediterranean-climate ecosystems. Global Ecology and Biogeography $14,509-519$.

di Castri, F., 1981. Mediterranean-type shrublands of the world. In: di Castri, F., Goodall, D. W., Specht, R. L. (Ed.), Mediterranean-type shrublands. Elsevier, Amsterdam, pp. 152.

Clausen, C.P., 1952. Biological control of insect pests. California Citrograph, 37, 182, 204, 206.

Collier, T., Van Steenwyk, R., 2004. A critical evaluation of augmentative biological control. Biological Control, 31, 245-256.

Dahms, E.C., Smith, D., 1994. The Aphytis fauna of Australia. In: Rosen, D. (Ed.), Advances in the Study of Aphytis. Intercept Limited, UK, pp. 245-255.

DeBach, P., 1948. The establishment of the Chinese race of Comperiella bifasciata on Aonidiella aurantii in southern California. Journal of Economic Entomolgy, 46, 1103.

DeBach, P., 1953. The establishment in California of an oriental strain of Prospaltella perniciosi Tower on the California red scale. Journal of Economic Entomology, 46, 1103.

DeBach, P., Argyriou, L.C., 1966. Effects of short-duration suboptimum preoviposition temperatures on progeny production and sex ratio in species of Aphytis (Hymenoptera: Aphelinidae). Research Population Ecology 8, 69-77.

DeBach, P., Fisher, T.W., Landi, J., 1955. Some effects of meteorological factors on all staes of Aphytis lingnanensis, a parasite of the California red scale. Ecology 36, 743-753.

DeBach, P., Rosen, D., 1991. Biological control by natural enemies. pp. 440. $2^{\text {nd }}$ ed. Cambridge, United Kingdom. 
Duale, A.H., 2005. Effect of Temperature and Relative Humidity on the Biology of the Stem Borer Parasitoid Pediobius furvus (Gahan) (Hymenoptera: Eulophidae) for the Management of Stem Borers. Environmental Entomology 34, 1-5.

Costa, M., 1999. La vegetación y el paisaje en las Tierras valencianas. Rueda publications. Madrid, Spain.

Flanders, S.E., 1944. Observations on Comperiella bifasciata, an endoparasite of diaspine coccids. Annals of the Entomological Society of America 37, 365-371.

Forster, L.D., Luck, R.F., Grafton-Cardwell, E.E., 1995. Life stages of California red scale and its parasitoids. University of California. Division of Agriculture and Natural Resources. Publication no 21529.

Forster, L.D., Luck, R.F., 1996. The role of natural enemies of California red scale in an IPM program in California citrus. In: Proceedings of the International Society of Citriculture, Sun City, South Africa, pp. 504-507.

Furness, G.O., Buchanan, G.A., George, R.S., Richardson, N.L., 1983. A history of the biological and integrated control of red scale, Aonidiella aurantii on citrus in the lower Murray valley of Australia. Entomophaga 28, 199-212.

Godfray, H.C.J., 1994. Parasitoids: Behavioral and Evolutionary Ecology. Princeton University Press, Princeton, N.J., USA.

Goolsby, J.A., DeBarro, P.J., Kirk, A.A., Sutherst, R.W., Canas, L., Ciomperlik, M.A., Ellsworth, P.C., Gould, J.R., Hartley, D.M., Hoelmer, K.A., Naranjo, S.E., Rose, M., Roltsch, W.J., Ruiz, R.A., Pickett, C.H., Vacek, D.C., 2005. Post-release evaluation of biological control of Bemisia tabaci biotype " $\mathrm{B}$ " in the USA and the development of predictive tools to guide introductions for other countries. Biological Control 32, $70-77$.

Greathead, D., Greathead, A., 1992. Biological control of insect pests by insect parasitoids and predators: the BIOCAT database. Biocontrol News and Information 13, 61-68.

Guirrou, Z., El Kaoutari, I., Boumezzough, A., Chemseddine, M., Hilal, A., 2003. Contrôle des populations d'Aonidiella aurantii (Maskelle) en vergers d'agrumes au Maroc. Fruits 58, 3-11. 
Gurr, G.M., Wratten, S.D., 2000. Biological Control: Measures of Success. Kluwer Academic Publishers, Dordrecht, The Netherlands.

Hall, R.W., Ehler, L.E., 1979. Rate of establishment of natural enemies in classical biological control. Bulletin of the Entomological Society of America 25, 280-282.

Hance, T., van Baaren, J., Vernon, P., Boivin, G., 2007. Impact of extreme temperatures on parasitoids in a climate change perspective. Annual Review of Entomology 52, $107-$ 126.

Kalyebi, A., Sithanantham, S., Overholt, W.A., Hassan, S.A., Mueke, J.M., 2005. Parasitism, longevity and progeny production of six indigenous Kenyan trichogrammatid egg parasitoids (Hymenoptera: Trichogrammatidae) at different temperature and relative humidity regimes. Biocontrol Science and Technology 15, 255-270.

Kfir, R., Luck, R.F., 1984. Effect of temperature and relative humidity on developmental rate and adult life span of three Aphytis species (Hym., Aphelinidae) parasitising California red scale. Journal of Applied Entomology, 97, 314-320.

Mann, J.A., Axtell, R.C., Stinner, R.E., 1990. Temperature-dependent development and parasitism rates of four species of Pteromalidae (Hymenoptera) parasitoids of house fly (Musca domestica) pupae. Medical and Veterinary Entomology 4:245-253.

McEvoy, P.B., Coombs, E.M., 2000. Why things bite back: unintended consequences of biological weed control. In: Follett, P.A., Duan, J.J. (Ed.), Non-Target Effects of Biological Control. Kluwer Academic Publishers, Boston, Massachusetts, pp. 167194.

Lavandero, B., Muñoz, C., Barros, W., 2006. El talón de Aquiles del control biológico: una nueva visión para su éxito. Agro-Ciencia 22, 111-123.

Liu, S.S., Zhang, G.M., Zhu, J., 1995. Influence of temperature variations on rate development in insects analysis of case studies from entomological literature. Annals of the Entomological Society of America 88, 107-119.

Luck, R.F., Podoler, H., 1985. Competitive exclusion of Aphytis lingnanensis by A. melinus: Potential role of host size. Ecology 66, 904-913.

Messenger, P.S., 1959. Bioclimatic studies with insects. Annual Review of Entomology 4, 183-206. 
Meyer, J.S., Igersoll, C.G. MacDonald, L.L., Boyce, M.S., 1986. Estimating uncertainty in population growth rates: jackknife vs. bootstrap techniques. Ecology 67, 1156-1166.

Millán, M.M., Estrela, M.J., Miró, J., 2005. Rainfall components: variability and spatial distribution in a Mediterranean area (Valencia region). Journal of Climate 18, 26822705.

Mills, N.J., 2000. Biological control: the need for realistic models and experimental approaches to parasitoid introductions. In: Hochberg, M.E. Ives, A.R. (Ed.), Parasitoid Population Biology. Princeton University Press, Princeton, N.J., USA, pp. 217-234.

Murdoch, W.W., Briggs, C.J., Nisbet, R.M., 1996. Competitive displacement and biological control in parasitoids: a model. The American Naturalist 148, 807-826.

Pandey, A.K., Tripathi, C.P.M., 2008. Effect of temperature on the development, fecundity, progeny and life-table of Campoletis chlorideae, an endolarval parasitoid of the pod borer, Helicoverpa armigera. BioControl 53, 461-471.

Peacock L., Worner, S., Sedcole, R., 2006. Climate variables and their role in site discrimination of invasive insect species distributions. Environmental Entomology 35, 958-963.

Pérez, A.J., 1994. Atlas climático de la Comunidad Valenciana. Generalitat Valenciana, COPUT, Serie Territorio, Valencia, Spain.

Pina, T., Verdú, M.J., 2007. El piojo rojo de California Aonidiella aurantii (Maskell) y sus parasitoides en cítricos de la Comunidad Valenciana. Boletín Santidad Vegetal 33, 357-368.

Reeve, J.D., Murdoch, W.W., 1986. Biological control by the parasitoid Aphytis melinus and population stability of the California red scale. Journal of Animal Ecology 55, 10691082.

Richardson, N.L., 1978. Biological aspects of co-existence between Comperiella bifasciata Howard (Hymenoptera: Chalcidoidea: Encyrtidae) and Aphytis spp. Howard (Hymenoptera: Chalcidoidea: Aphelinidae). Proceedings of the International Society of Citriculture. Sidney, Australia, pp. 150-153. 
Rosen, D., DeBach, P., 1978. Diaspididae. In: Clausen, C. P. (Ed.), Introduced parasites and predators of arthropod pest and weeds: A world review. USDA-ARS. Handbook 480. U. S. Department of Agriculture, Washington D. C., pp. 78-128.

Rosen, D., DeBach, P., 1979. Species of Aphytis of the world (Hymenoptera: Aphelinidae). Israel, Univ. Press, Jerusalem.

Rosen, D., 1994. Advances in the study of Aphytis (Hymenoptera: Aphelinidae). Intercept Limited, Andover, UK.

Siemann, E., Tilman, D., Ritchie, M., 1998. Experimental tests of the dependence of arthropod diversity on plant diversity. The American Naturalist 152, 739-750.

Siscaro, G., Di Franco, F. Zappalà L., 2008. On the presence and diffusion of Comperiella bifasciata How. (Hymenoptera: Encyrtidae) in Southern Italy. IOBC/wprs Bulletin $38,42-45$.

Smith, D., Beattie, G.A.C., Broadley, R., 1997. Citrus pests and their natural enemies. Integrated pest management in Australia. Dept. of Primary Industries. Queensland, Australia.

Solomon, M.E., 1951. Control of humidity with potassium hydroxide, sulphuric acid, or other solutions. Bulleting of Enlomological Research 42, 543-54.

Sorribas, J., Rodriguez, R., Rodrigo, E., Garcia-Marí, F., 2008. Parasitism levels and species of natural enemies in field populations of California red scale Aonidiella aurantii (Hemiptera: Diaspididae) in eastern Spain. IOBC/wprs Bulletin 38, 26-33.

Sorribas, J., Garcia-Marí, F., 2010. Comparative efficacy of different combinations of natural enemies for the biological control of California red scale in citrus groves. Biological control 55, 42-48.

Sorribas, J., Rodriguez, R., Garcia-Marí, F., 2010. Parasitoid competitive displacement and coexistence in citrus agroecosystems: linking species distribution with climate. Ecological Applications 20, 1101-1113.

Stiling, P., 1993. Why do natural enemies fail in classical biological control programs? American Entomologist 39, 31-37.

Southwood, T.R.E., Henderson, P.A., 2000. Ecological Methods. Blackwell Science, Oxford. 
Sweetman, H.L., 1933. Studies of chemical control of relative humidity in closed spaces. Ecology 14, 40-45.

Villalpando, S. N., Williams, R. S., Norby, R.J., 2009. Elevated air temperature alters an oldfield insect community in a multi-factor climate change experiment. Global Change Biology 15, 930-942.

Viggiani, G., 1990. Endoparasites. In: Rosen, D. (Ed.), Armored scale insects, their biology, natural enemies and control. Vol B. Elsevier. Oxford, New York, Tokyo, pp 121-132.

Ward, N.L., Masters, G.J. 2007. Linking climate change and species invasion: an illustration using insect herbivores. Global Change Biology 13, 1605-1615.

Yu, D.S., Luck, R.F., Murdoch, W.W., 1990. Competition, resource partitioning and coexistence of an endoparasitoid Encarsia perniciosi and an ectoparasitoid Aphytis melinus of the California red scale. Ecological Entomology 15, 469-480. 



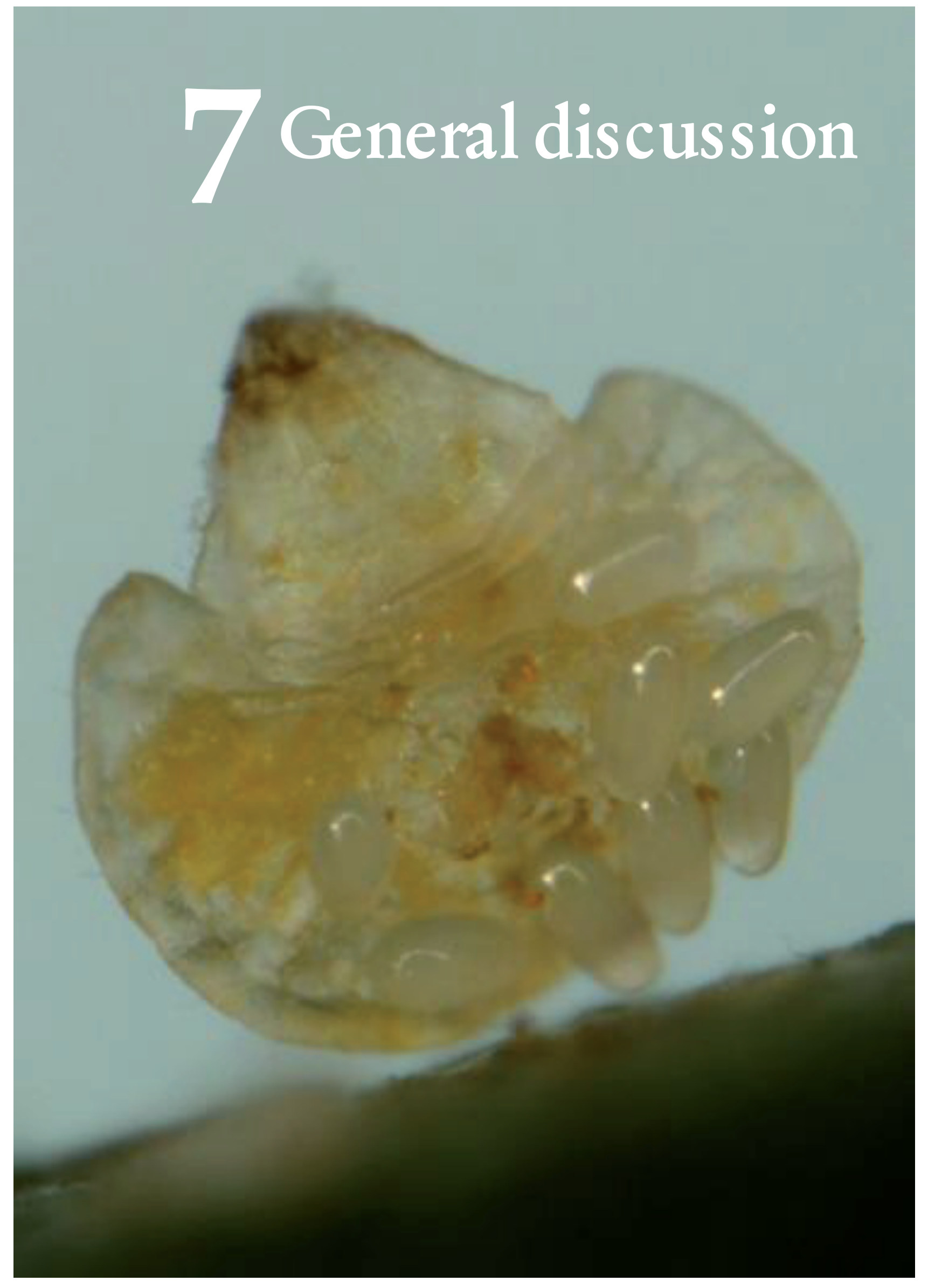



Contrary to what was stated in previous studies, both A. melinus and $A$. chrysomphali can coexist and complement throughout the year under the appropriate climatic conditions. That is the case of most coastal citrus areas of eastern Spain where the native $A$. chrysomphali reaches similar or even higher proportions than the introduced and superior competitor A. melinus. Theoretical displacement does not occur when winter temperatures are low enough to allow the better cold adapted $A$. chrysomphali to emerge earlier in the year and to build up enough population to successfully compete with A. melinus allowing the alternation of both species along the year. Laboratory experiments under constant humidity and temperature do not allow this alternation and could be the reason why most laboratory assays concluded that one Aphytis species always excludes the other when they are together. Else, although both parasitoids showed a certain degree of overlap in their niches, $A$. chrysomphali preferred second instar stages whereas A. melinus preferred the bigger virgin female instars which appear later in the year.

However, under the hot and dry summer conditions typical from the south and inland citrus areas of Spain (or San Joaquin Valley in California for instance) $A$. melinus, native to hot regions of India, has completed the displacement of $A$. chrysomphali which requires fresh and humid conditions and whose population suffers a strong reduction during hot periods. This could be the explanation why we found an increasing proportion of $A$. chrysomphali as we move to the north where summers are less hot. Nevertheless, current climate change toward warmer temperatures could affect this equilibrium allowing the exclusion of $A$. chrysomphali from northern areas. In fact, new unpublished data about an increase in A. melinus proportion in the northern citrus area during the warm years 2009-2010 suggest Aphytis proportions, which have been maintained stable during the last ten years (as it can be corroborated through the comparison with previous studies) could be modified toward a higher proportion of A. melinus.

Another introduced Aphytis species, A. lingnanensis, has not extended, however, as it did in other coastal citrus areas around the world. Releases of $A$. lingnanensis only achieved the establishment in a very small semitropical citrus area where this parasitoid was found in groves around the point of release. In this humid area the endoparasitoid E. perniciosi was commonly found in most citrus groves 
reaching a significant proportion mainly during early spring, when Aphytis population is low. Moreover, E. perniciosi can parasitize CRS instars that Aphytis are not able to parasitize, like first instars or mature females, and, in contrast to Aphytis it preferred to parasitize CRS growing on branchlets. Hence, this endoparasitoid can be considered as a good complement for Aphytis species in the control of the host.

This was confirmed by the global parasitism rates attained in the three ecosystems studied. In effect, our results about parasitism levels reached by different parasitoid populations showed that $A$. melinus achieves higher average parasitism levels throughout the year than A. chrysomphali. Else, it deposits two eggs or more on the scale body much more often than A. chrysomphali. But the best CRS control was obtained in groves where the three parasitoid species (A. melinus, $A$. chrysomphali and E. perniciosi) coexist. Therefore, it can be said that the higher the number of coexisting species the better for host control. In areas with low number of species the possibility of introducing new parasitoid species should be considered. Good candidates could be $H$. rouxi or $A$. coheni, whose efficacy has been demonstrated in citrus areas with similar climate like South Africa or Israel

The highest global parasitism rates along the year were measured during summer and beginning the autumn and the lowest at the end of winter and beginning of spring. This should be taken into account to select the adequate period for mineral oil treatments or parasitoid releases to reduce CRS infestations. The natural mortality of $A$. aurantii population must be also considered in any control program as it can reach very high levels. In our experiences this was particularly important during May reaching $70 \%$ of the analyzed scales.

On the other hand, our results demonstrated that the observation of Aphytis remnants (meconial pellets, exit holes, pupal cases or dead parasitoids) under dead scales can be used as a valid and rapid method to estimate the effect of parasitoids on the host population. The slow and laborious process of finding a representative number of life scales of each stage can be replaced for the faster procedure of examining dead scales.

The effect of predators on A. aurantii populations, although much lower in importance than parasitoids, was however significant, as larval stages of several predatory species (mainly L. aonidiellae and R. lophantae) were able to prey even 
on mature females and therefore complement parasitoid action. Predator longevity is usually longer than parasitoids and they can feed on many scales along its life. Besides, most predators feed on crawlers and early instars of the scale although this effect is difficult to measure as no host residuals are left. Thus, the rearing and releasing of existing or introduced predators should be considered in biological control programs. It is also possible to introduce two CRS predator species at the same time, a Coleoptera and a phoretic predator mite attached to its elytra when they are reared together. In the case of eastern Spain, the combination of C. bipustulatus and $H$. coccophagus, two effective CRS predators in many citrus areas around the world whose abundance in our field surveys was much lower than in other citrus areas, could result in a better scale control.

Being the main CRS parasitoids, the fitness and life history traits of Aphytis species under different climatic conditions have been widely studied. However, that is not the case of the two main endoparasitoids complementing Aphytis activity; few works have studied the fitness of $C$. bifasciata and E. perniciosi under laboratory or field conditions. The data obtained from our experiments on progeny production, adult lifespan, development time and sex ratio under different temperature and humidity conditions could have direct application on biological control programs in order to decide which parasitoid species can be more adequate to be introduced in a particular citrus area.

From our field and lab results we can conclude that inland citrus areas of eastern Spain (and in general, inland citrus areas around the world) present the adequate climatic conditions for the establishment and development of $C$. bifasciata in coexistence with A. melinus. Comperiella bifasciata showed its best rate of increase under high constant temperature and low humidity and is able to oviposit on scale instars not available for Aphytis, so it can be considered as a good complement of A. melinus in hot-dry areas. Else, the calculated adult longevity of C. bifasciata was much longer than the longevity estimated in other works for Aphytis under warm temperatures. As it has been demonstrated in other Mediterranean citrus areas like Morocco or Sicily (citrus regions with similar climatic conditions to those found in eastern Spain), this species needs long time for its expansion after establishment but after five to ten years it has been found in high numbers, in coexistence with $A$. melinus. Also, it can be considered as potential candidate parasitoid for releases in the hotter citrus regions of southern Spain. 
Warm-moist areas are good candidates for introductory programs with the species E. perniciosi. This species had a high rate of increase in the experiments that combined elevated humidity with high temperature. These are the climatic conditions of the citrus area where it was found in eastern Spain. However, out of these regions E. perniciosi could have problems to survive under dry summers as it was not able to oviposit at high constant temperature combined with $45 \%$ relative humidity. Its longevity was also low under these conditions, which are common during the summer in many citrus areas of the Mediterranean basin.

As it has been demonstrated in other citrus areas around the world, it is necessary to encourage the higher complex of CRS natural enemies coexisting in a citrus grove. It is only in combination that beneficial parasitoids and predators significantly reduce scale density as limitation of one natural enemy is often compensated by the strengths of another. The results of the introductory program of new species complementing Aphytis have shown that, in order to achieve good results with the introduction of new species, the use of squashes infested with parasitized scales is a valid and economic method. The distribution in different citrus climatic areas of the release sites with small numbers of squashes seems to be more efficient than the traditional massive releases of adult parasitoids in few groves. This is also true because as we have demonstrated parasitoids are very climate-specific and the optimal conditions for the establishment of a species may change in few kilometres being very important to cover different micro-climate areas.

The analysis of climatic data from the three studied agroecosystems showed that slight differences in winter and summer temperatures or relative humidity between neighbour ecosystems were responsible of a large variation in parasitoid species composition. The relative humidity, which very often is not considered in laboratory experiments, was a decisive factor for the fitness of parasitoid species, being moisture conditions of one specific area an important limiting factor for the establishment of parasitoids. Temperature and humidity regime strongly affected the adult longevity, the progeny production, the sex ratio and the biotic potential of both studied endoparasitoids.

Our results combining both field and laboratory studies confirm the validity of using the calculated value of $r_{m}$ at different temperature-humidity regimes to forecast the successful establishment of newly introduced parasitoid insects in a particular climatic area. This could have implications on reducing the high number

$$
-168-
$$


of unsuccessful releases (referred by numerous authors) on biological control programs based on the introduction of new parasitoid species. Probably, previous laboratory trials with candidate insects for introduction to obtain their $r_{m}$ at different temperature-humidity regimes would give the necessary information to select the adequate habitats for their introduction and to diminish the number of unsuccessful releases.

The different effects of climate warming on native and introduced parasitoids could be added to the previously indicated reasons for the displacement of $A$. chrysompali to explain why A. melinus, which shows high phenotypic plasticity, has become the dominant parasitoid in areas where it was recently in low proportion. As we have demonstrated parasitoids are extremely sensitive to temperature and humidity conditions and a small variation in the climate conditions due global warming (specially an increase in the average summer temperature) could have a decisive impact on the parasitoid ecosystems, allowing the expansion of some species and causing the extinction of others. 

8 Conclusions
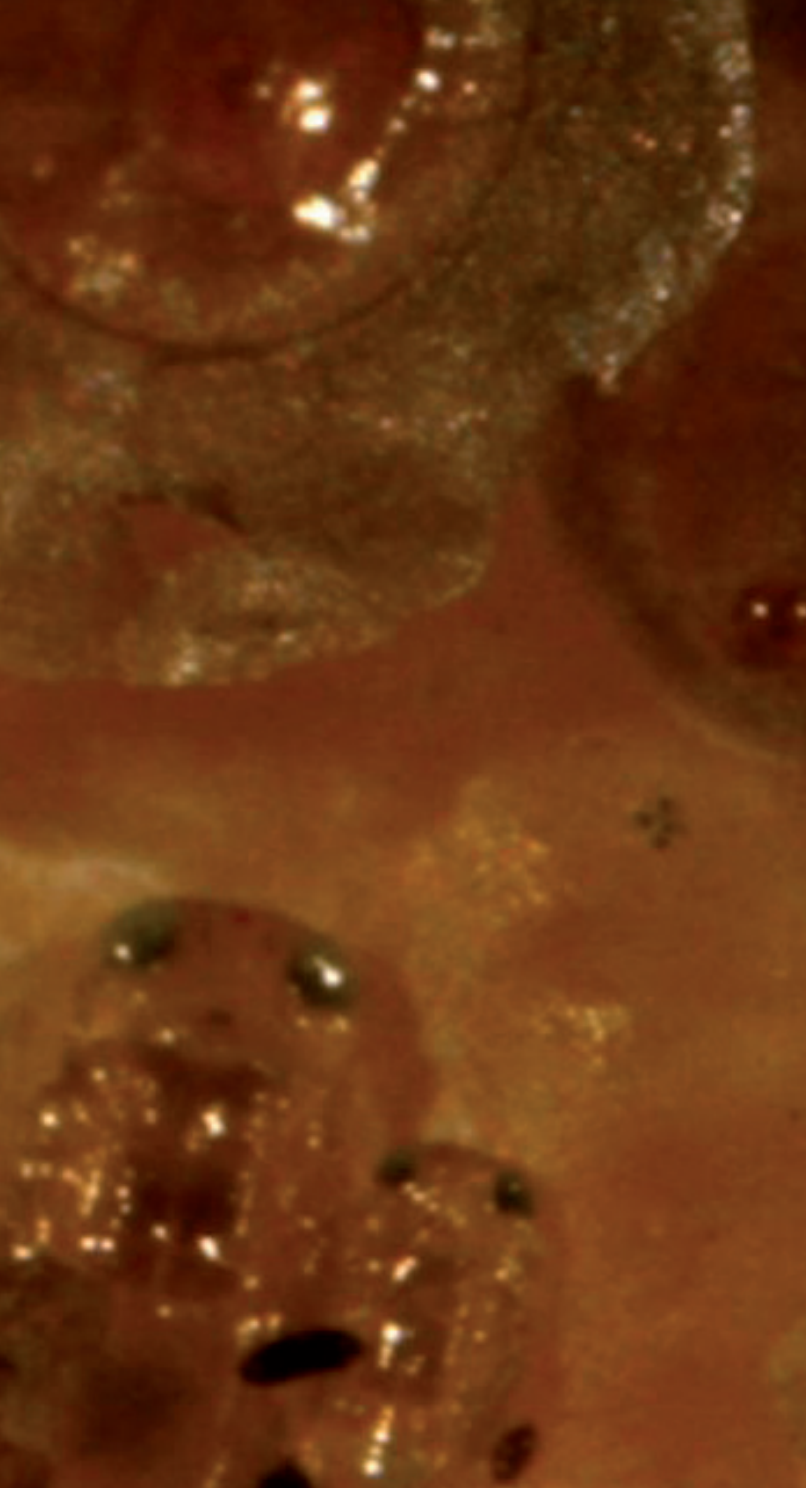



\section{Parasitoid competitive displacement and coexistence in citrus agroecosystems: linking species distribution with climate}

i. Aphytis melinus and A. chrysomphali coexist along the western Mediterranean coast as the two main CRS parasitoid species.

ii. The relative proportion of each species depends of weather conditions, mainly hot summer temperatures that affect more negatively $A$. chrysomphali. Northern citrus areas with milder summers contain higher proportion of $A$. chrysomphali whereas in southern areas with hot and dry summers the native $A$. chrysomphali has been completely displaced by the introduced $A$. melinus.

iii. When a new generation of CRS starts in spring, its younger host preference and better cold resistance allows $A$. chrysomphali to emerge earlier in the year and build up sufficient population to avoid the competitive exclusion by $A$. melinus. That means they coexist via temporal niche partitioning.

iv. The negative effect of cold temperatures on A. melinus it also shown by the male biased offspring during the winter.

v. Theories about insterspecific competition displacement between homologous insect species based on Aphytis species should be reconsidered as they are not strict ecological homologues since they prefer different host stages and different periods of the year. Its action in the biological control of A. aurantii can be considered as complementary.

vi. Encarsia perniciosi and A. lingnanensis are present in a semitropical area (La Marina), being the former the more abundant (13\% of the total parasitoids).

vii. Aphytis chrysomphali reaches its population peak in October and A. melinus in August. Captures of Aphytis were very low before the first peak of males of A. aurantii in spring. Mass releases of Aphytis parasitoids in biological control programs should be focused on spring, when naturally occurring parasitoids are usually scarce and the scale population is available for parasitism. 


\section{Comparative efficacy of different combinations of natural enemies for the biological control of California red scale in citrus groves}

i. Aphytis melinus prefers young females for parasitism whereas $A$. chrysomphali prefers second instar stages and E. perniciosi highly parasitized scale molts and gravid females that are not parasitizable by Aphytis.

ii. The highest parasitism levels by Aphytis were reached in late summer/early autumn and the lowest in late winter/early spring. However, highest levels of parasitism by E. perniciosi were reached during the spring showing that this endoparastioid could constitute a good complement of ectoparasitoids.

iii. Encarsia perniciosi showed higher preference for the scales on twigs whereas scales on fruits were highly preferred for parasitism by Aphytis.

iv. In the orchards where A. melinus was the dominant parasitoid, either alone or coexisting with $A$. chrysomphali, parasitism rates were higher (average $22.4 \%$ ) than in the orchards where A. chrysomphali was predominant (average $11.5 \%)$.

v. The best parasitism level was achieved in the groves where Aphytis occurred together with E. perniciosi.

vi. The analysis of dead scales killed by Aphytis confirms the results obtained in parasitism of live scales. The average annual mortality rate of A. aurantii was $73.6 \%$.

vii. The most abundant predators were Lestodiplosis aonidiellae and Rhyzobius lophantae. Its effect on reducing CRS population was much lower than parasitoids. 


\section{Effects of climate the introduction, distribution and biotic} potential of parasitoids: Applications to biological control of California red scale

i. Slight differences in winter and summer temperatures or humidity conditions between contiguous Mediterranean ecosystems are responsible of large variations in parasitoid species composition emphasizing the importance of considering temperature and humidity at different levels besides the optimal.

ii. Most groves of the inland citrus area of eastern Spain contain A. melinus as the solely scale parasitoid. Releases of $C$. bifasciata in groves placed in this inland area achieved its establishment showing optimal potential to complement CRS biological control.

iii. Releases of E. perniciosi and A. lingnanensis successfully attained establishment only in the warm-humid coastal area.

iv. The highest $r_{m}$ values obtained in laboratory for C. bifasciata and $E$. perniciosi were reached at temperature-humidity regimes typical from inland and subtropical citrus areas respectively, the same areas in which releases of these parasitoids achieved its establishment.

v. Previous unsuccessful releases and the distribution of CRS parasitoids in different areas around the world can be explained through the $r_{m}$ of these insects at different temperature-humidity regimes.

vi. The adult longevity of both species at different temperature-humidity conditions also reflected their adaptability to dry or humid areas.

vii. The results with CRS endoparasitoids, together with previous studies on Aphytis species and their field distribution, demonstrate the validity of $r_{m}$ analysis in laboratory at different extreme temperature-humidity combinations to predict the potential areas of establishment and distribution of newly introduced organisms due to pest invasions, human releases or climate change. 
